Historic, Archive Document

Do not assume content reflects current scientific knowledge, policies, or practices. 



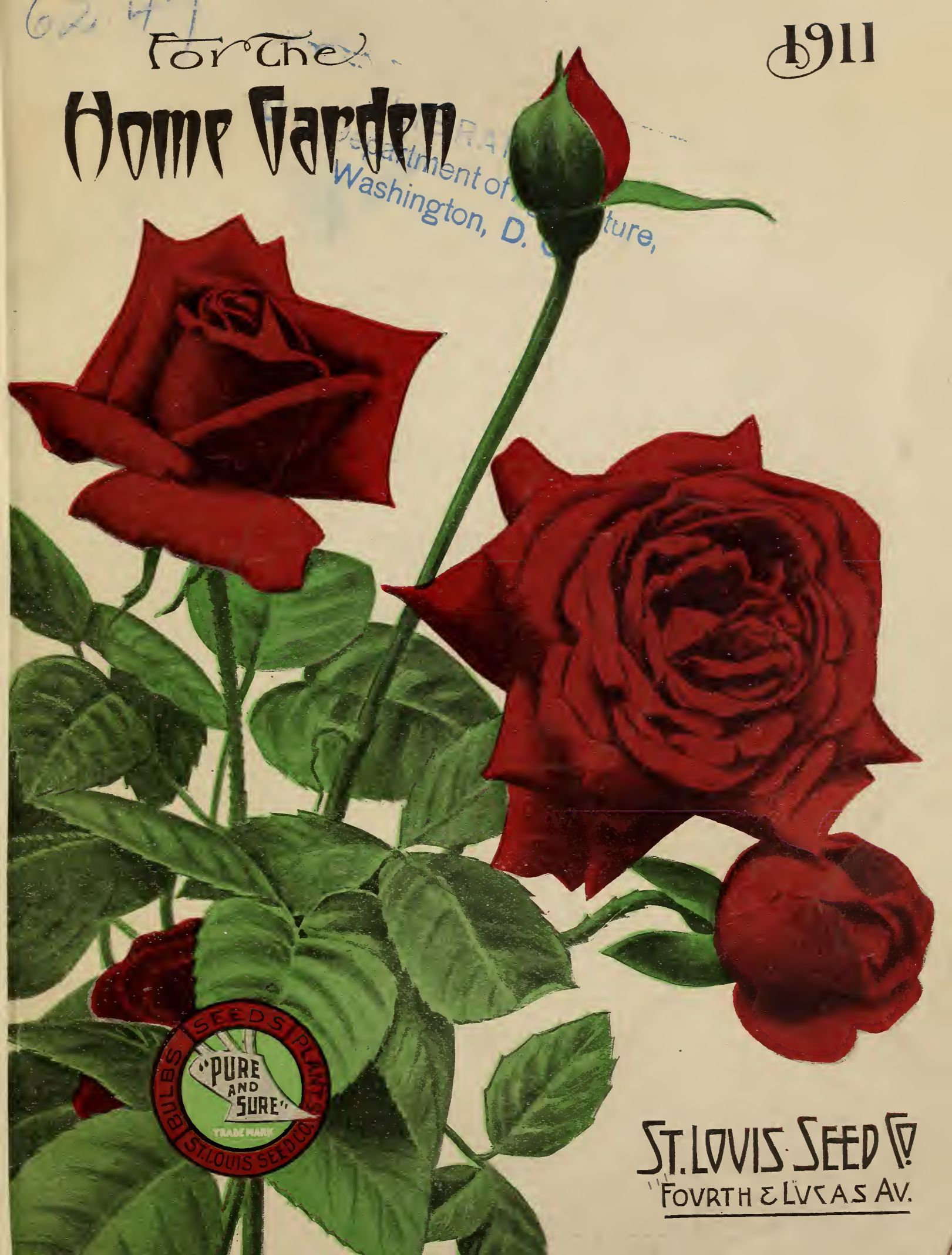


Date Forward by ( $\left.\begin{array}{l}\text { State whether wanted by } \\ \text { Mail, Express or Freight }\end{array}\right)$

\section{Name}

\section{State}

Reg. No.

Rural Roule No.

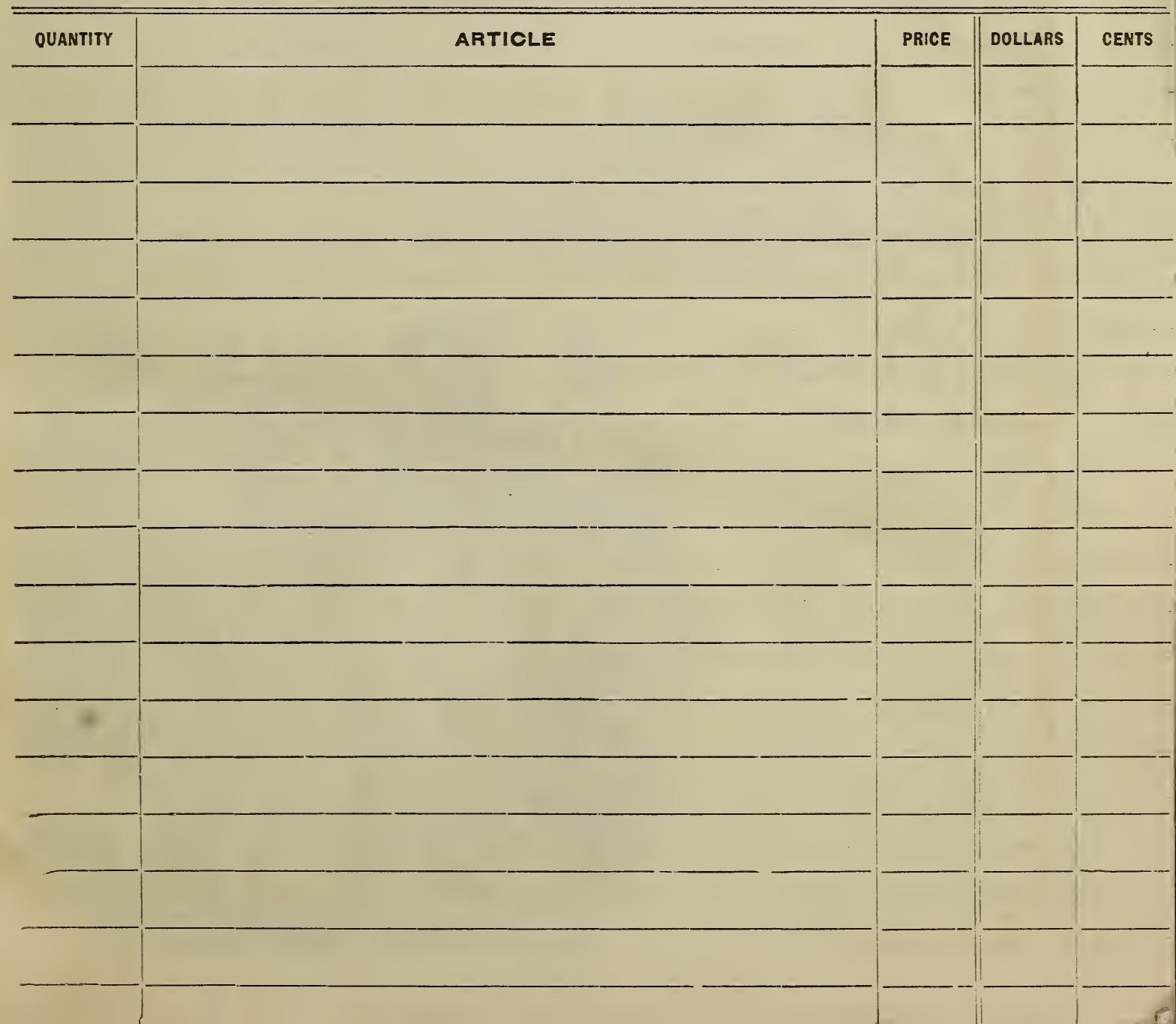

Expross or
Freight Offic

Post Office

County

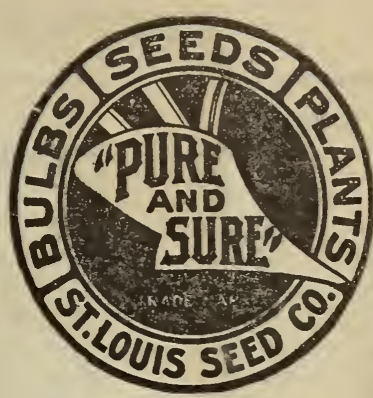




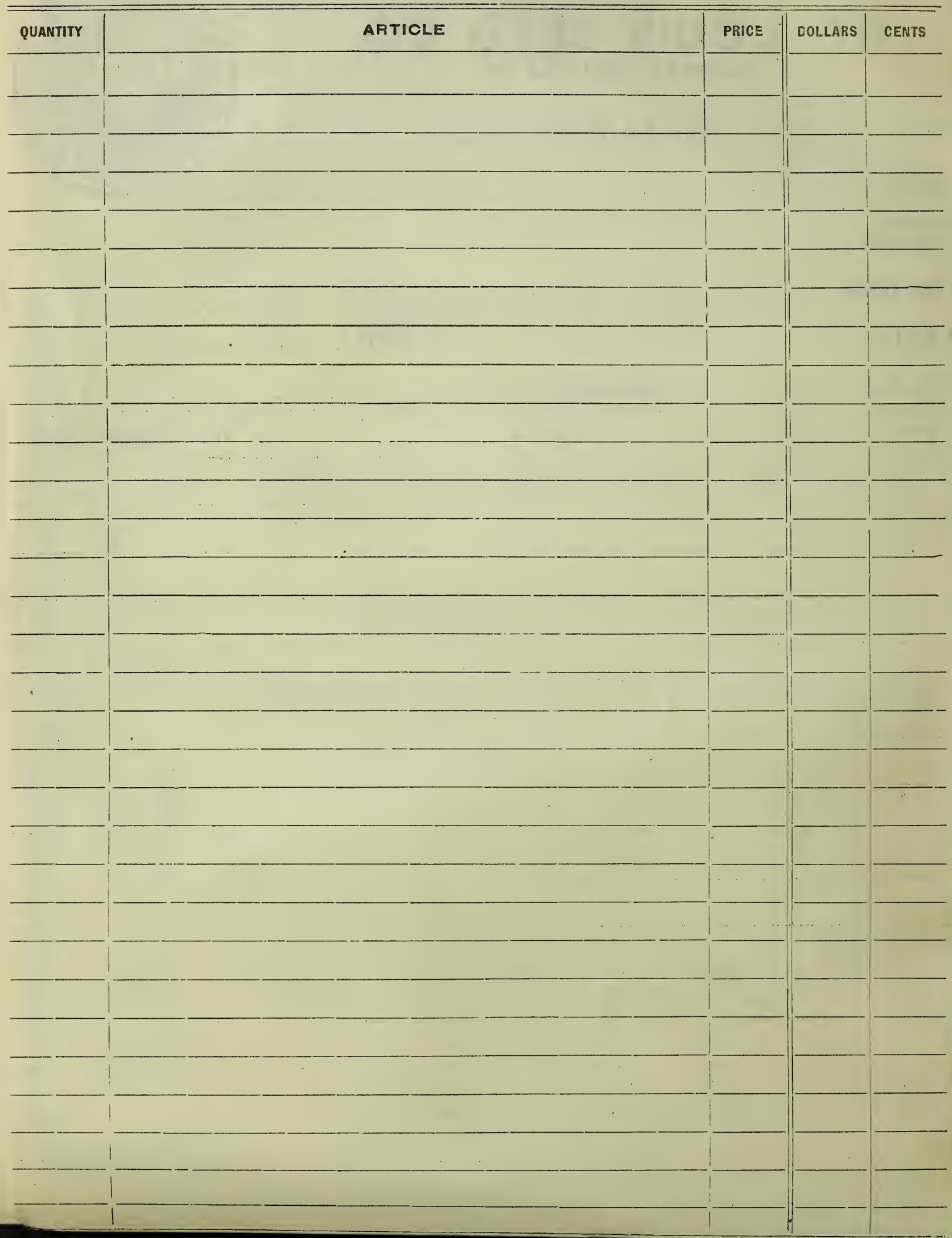




\section{(2) New Vegetable Creations for 1911 을 \\ NOVELTIES AND SPECIALTIES}

\section{Bountiful}

Green Podded Bush Bean

$\mathbf{T}$

HIS superior variety is a distinct

improvement in green bush

beans, and has become exceedingly popular wherever known.

The plant is of remarkably handsome and thrifty growth, being prac tically rust and mildew proof. It is very hardy, extremely early, very prolific and bears continuously for several weeks; it is the first to give pods fit to pick in the spring.

But the crowning merit of this grand Bush Bean is in the rich green pods, which are of immense size, thick, broad, extra long, very uniform in shape, solid, meaty, and of high quality, meltingly tender and having a delicious flavor exclusively their own: moreover, the pods are absolutely stringless and entirely free from any tough, membranous lining, not only when young, but this tender "snap brittle" quality is retained even into maturity.

This variety, while unrivaled in its class for the home girden, is also coming into great demand among the truckers. (See cut.) Price: Pkt., $5 c ; 1 / 2$ pt., 10c; pt., 20c; qt., 30c.

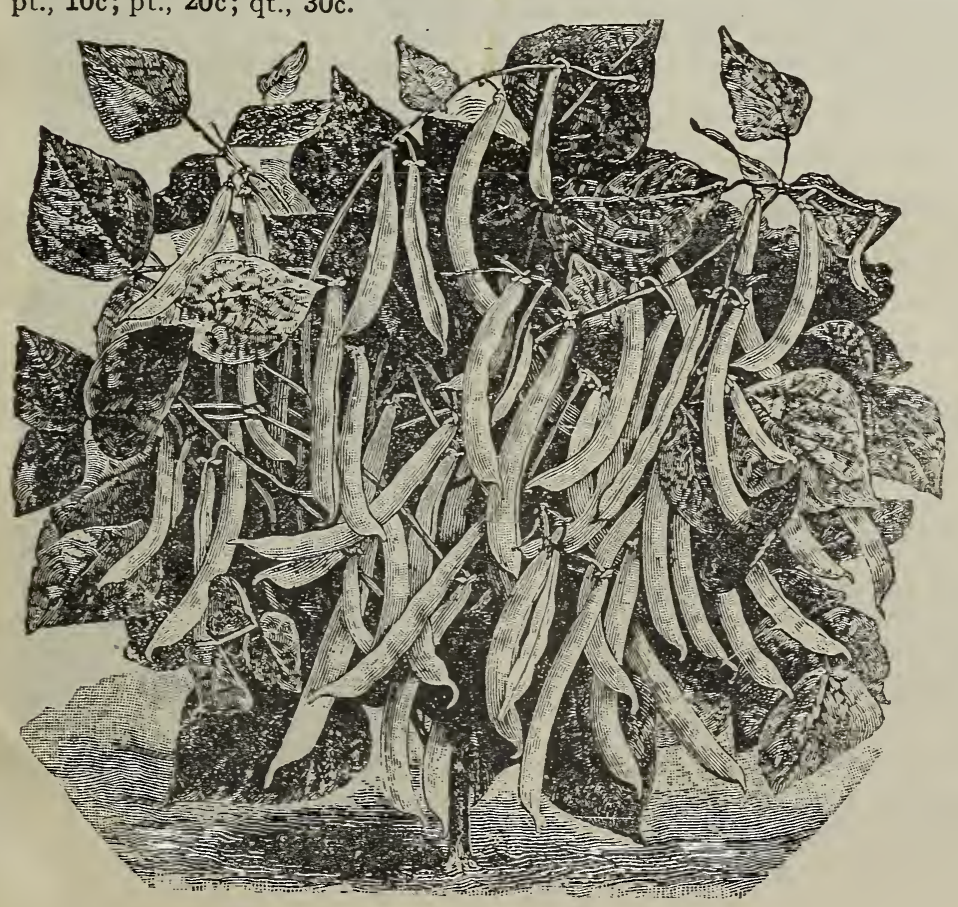

\section{New White Wax Bush Bean}

W E, in offering this new Wax vacancy that no other bean will do. That is one that has all the good points and none of the bad ones. This market has been using all green podded varieties, becau:e the older wax sorts soon become spotted after picking, and were never of high quality.

This variety is exceedingly handsome and very desirable, especially for the home garden. Vine dwarf, spreading and very productive. Pods are long, slightly curved, light yellow, wax-like, stringless and of the best quality. They are uniformly perfect, an ill-shaped one being rarely seen. Seed long, cylindrical, nearly white with a little dark marking about the eye. Price: Pkt., 10c; $1 / 2$ pt., $15 \mathrm{c}$; pt., $25 \mathrm{c}$; qt., $40 \mathrm{c}$ 


\section{BEET Nutting's Blood Red}

Greatest New Beet Offering in Recent Years

A $N$ ideal table Beet of beautiful form, rich, blood-red flesh, exceedingly delicious, tender and sweet beyond description. Its very small tap root, together with its superb size of globular

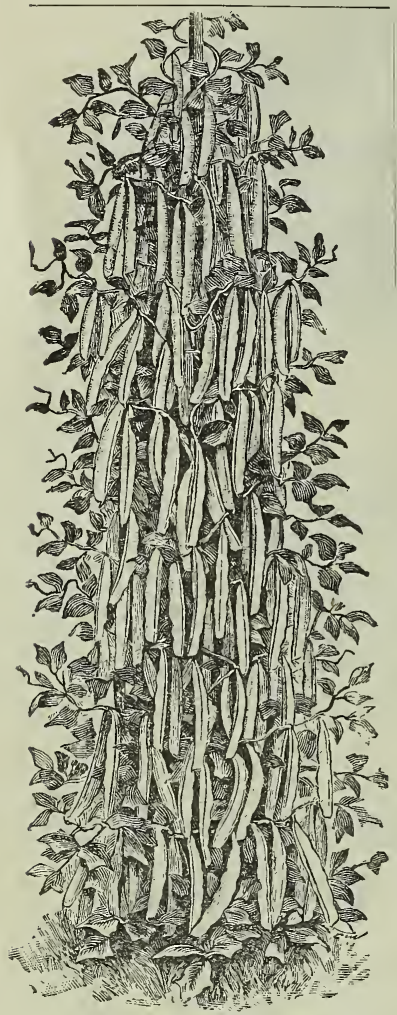

New White Cornfield form, make it an ideal beet for the market. The flesh is very fine grained and never woody or stringy. In short, we consider this the ideal beet of the day. Price: Pkt., 10c; oz., $15 \mathrm{c} ; \mathrm{I} / 4 \mathrm{lb} ., 30 \mathrm{c}$.

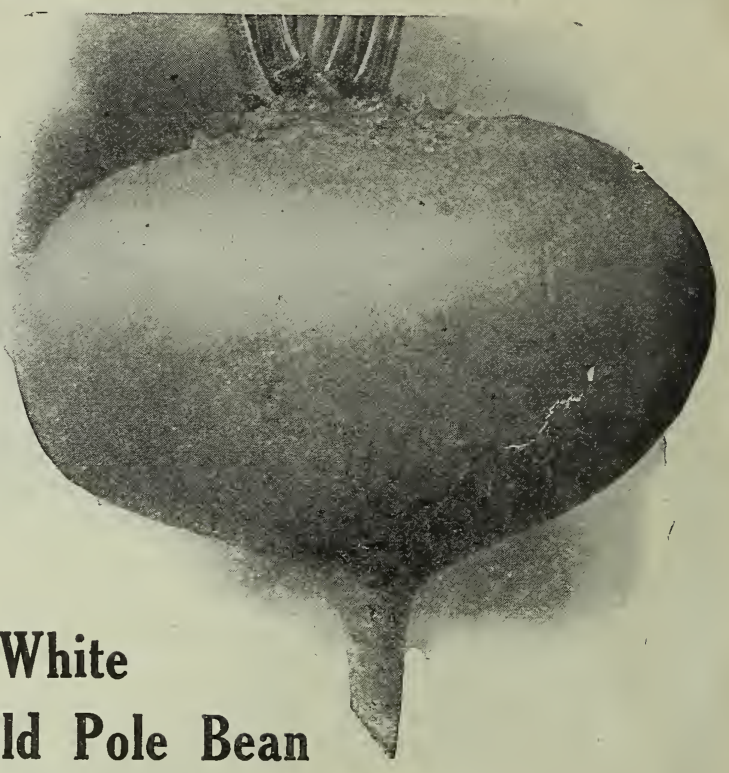

TN this new Pole Bean we have one that far surpasses anything on the market.

We have not had surplus stock to offer to all before, but have only a limited supply this season. This Bean is a cross between our regular White Cornfield and Kentucky Wonder; it is a fine long pod, round, thick and meaty green pod, with a white bean. It is a much heavier bean and far better shape than others, and will continue to bear far longer. We are the only ones who can offer you this new bean, and we are sure you will be highly pleased with the results.

Price: Ptt., 10c; $1 / 2$ pt., 15c; pt., 25c; qt., 50c.

\section{Our Business Grows Because \\ Our Seeds Grow}

\section{St. L. S. Co.'s New Improved Bush Lima}

TN this new variety we offer you the most productive Lima Bean in 1: existence. Pods are larger than any other Lima, and also considerably earlier. This new strain we consider superior to all others, both in quality and productiveness. Bushes grow low, well laden with broad, handsome pods, containing 3,4 and sometimes 5 beautiful beans. Meat is of a very appetizing flavor. Whether you grow for home use or market, it will pay you to devote a good share of your garden to this "King" of all Limas. We wish we had space to devote to the many flattering reports received regarding this wonderful variety. Price: Pkt., $10 \mathrm{c} ; \mathrm{r} / 2 \mathrm{pt}$, 15c; pt., 25c; qt., 40c.

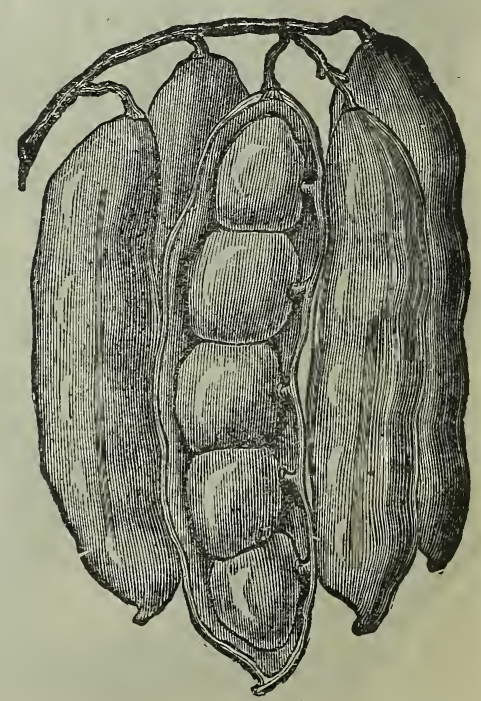




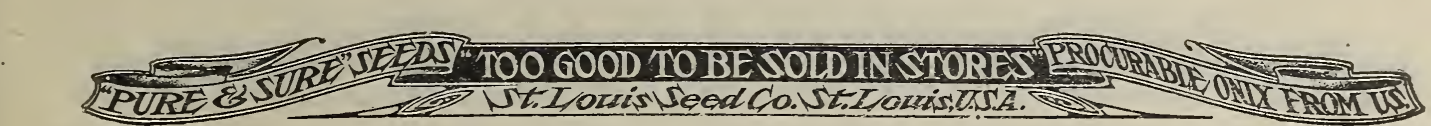

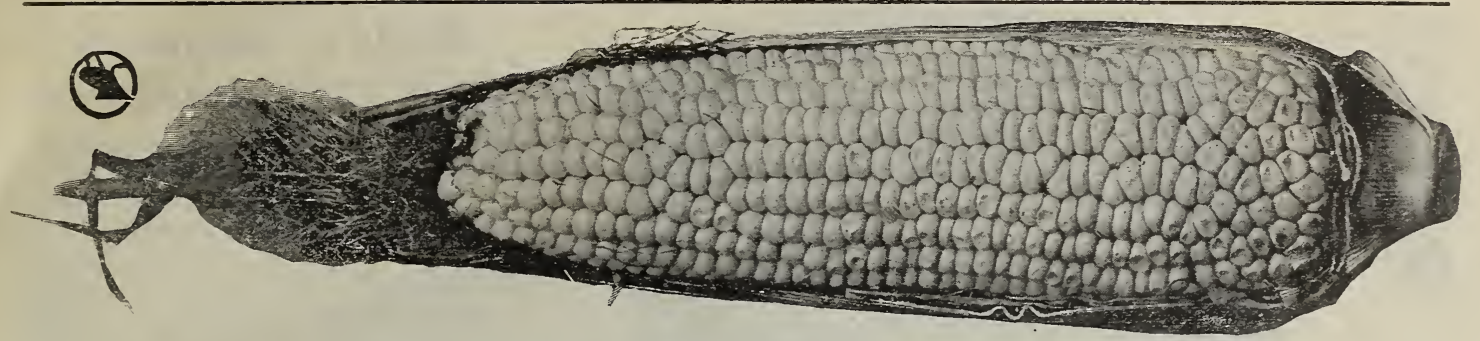

\section{Golden Bantam Sweet Corn}

ONE OF THE SWEETEST CORNS GROWN

Golden Bantam is a dwarf-growing early variety. The plant attains a height of only 3 or 4 feet, usually bearing two or more ears about 5 inches long to a stalk. These little fat ears are compactly filled

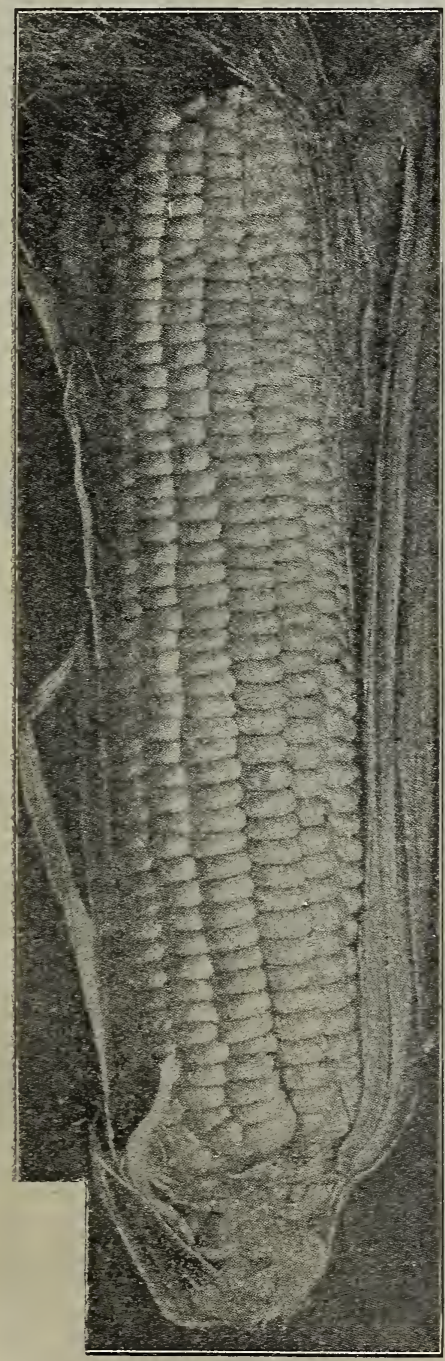

Superior with kernels, which, when ready for the table are cream-yellow, so lusciously sweet, tender and milky that some people claim it "the srown, therefore can be planted earlier with safety than other varieties.

Price: Pkt., 10c; $1 / 2$ pt., 15e; pt., 25e; qt., 40e.

\section{Superior Sweet Corn $\mathbb{6}$}

-Its Delicious, Plump, Pearly White,

\section{Milky Kernels Fairly Melt}

in Your Mouth.

This new early variety is undoubtedly the most productive of all sweet corn, as well as the finest eve discovered. Its mammoth yielding qualities are due to the fact that nearly every stalk produces from ${ }^{2}$ to 3 luscious ears of the finest quality. In fact, its chief quality lies in the point that it is the sweetest and most tender of any corn, as well as producing the most handsome ears imaginable. The stalk in itself is very distinct, growing only of medium height, but very thick; its firm husks insure it with retaining its sweetness longer than any other variety. In short, it is the biggest, the best and sweetest corn we have ever offered, and our customers know what this means. Price: Pkt.. 10c; 1/2 pt., 15e; pt., 20c; qt., 30c.

\section{Carrot}

\section{NEW GOLDEN STUMP-ROOTED}

Offered by us two seasons ago for the first time. It is' a magnificent stump-rooted carrot of a rich golden orange shade, and of a most excellent flavor. It is valuable for all uses, owing to its extreme sweetness and its enormous yielding merits; it will prove a bonanza to the gardener; ripening as it does very early, it also surpasses every other known variety in size, shape, yield and quality. (See cut.) Bะc.

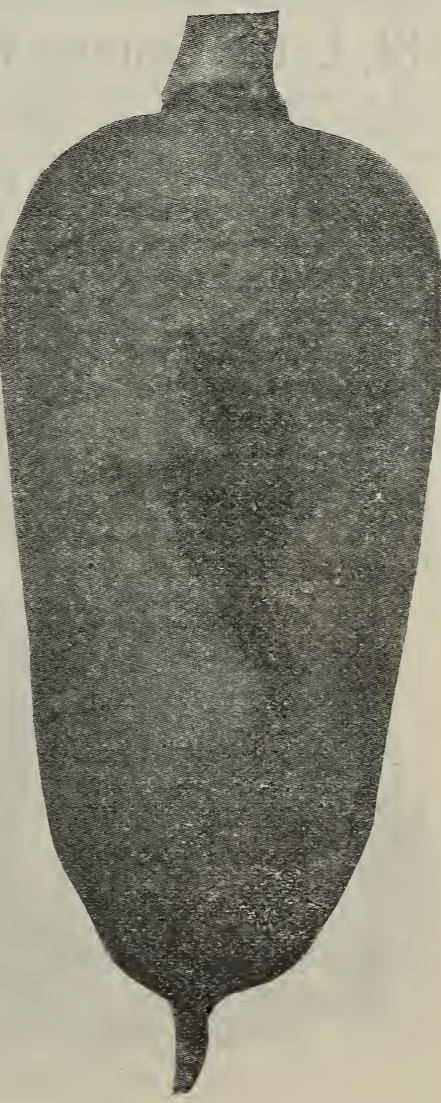




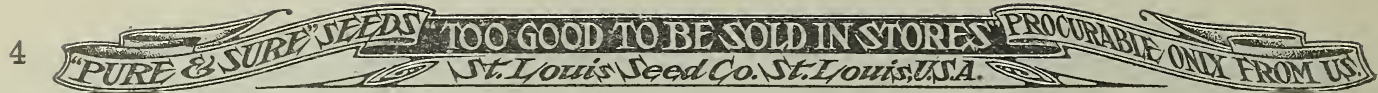

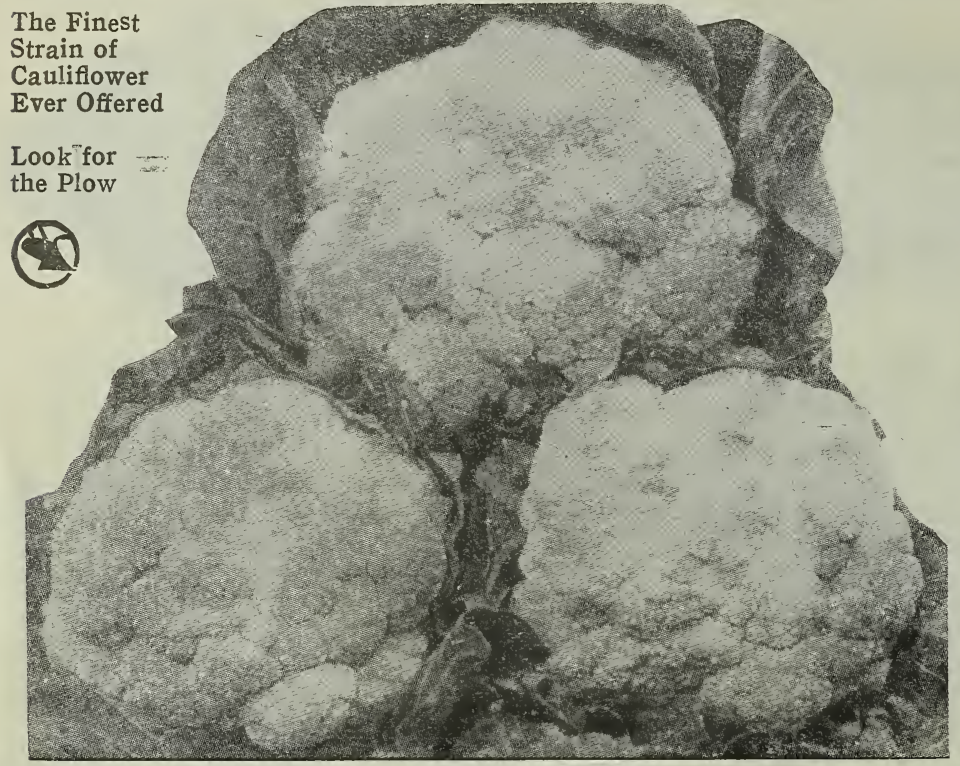

\section{Pride of Denmark 3 Cauliflower}

THE EARLIEST FORCING VARIETY IN EXISTENCE

This is the great new Caullflower that we introduced two seasons ago.

We challenge the world to produce the equal of this new white Cauliflower wonder. It is the finost, the hanosomest and the earliest Cauliflower in the world. as well as the largest species ever discovered. It is gorgeous beyond description. Its color is snow white, and its growth is of the most compact form. For an outdoor variety it cannot be surpassed. You who have. been planting the Dwarf Erfurt and Snowball varieties should give this new introduction a trial this season. It has been thoroughly tested in this locality and is sure cropper. Price: Plkt., 25c; $1 / 4$ oz., \$1.25; 1/2 oz., \$2.50; oz., \$5.00.

\section{We carry the best grade of Seeds}

\section{St. Louis Cannon Ball Cabbage}

A new Fall Cabbage well worthy of your attention Heads nearly round and hard as rock; fine ribbed. white and tender; an excellent variety for kraut and winter use. Will produce more pounds to the acre than any other variety. P'rice: Pkt., 10c; $1 / 2$ oz., 25c; oz., 50c.

\section{Get wise-Place your next order with us}

Succeeds where all other varieties fail. The best keeper. The largest headed. The finest quality.

This is the Cabbage that has made more money for gardeners than any other variety ever discovered.

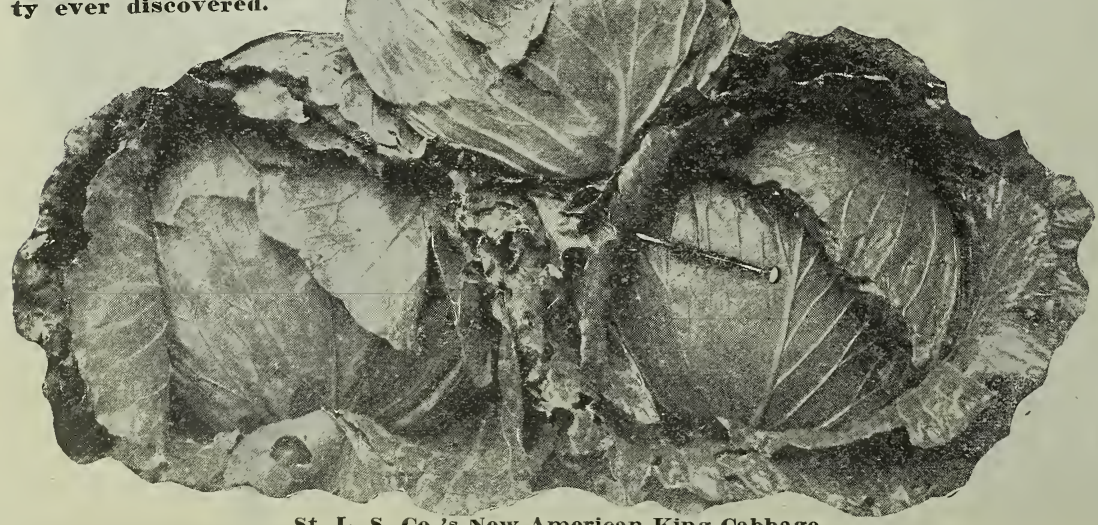

St. L. S. Co.'s New American King Cabbage

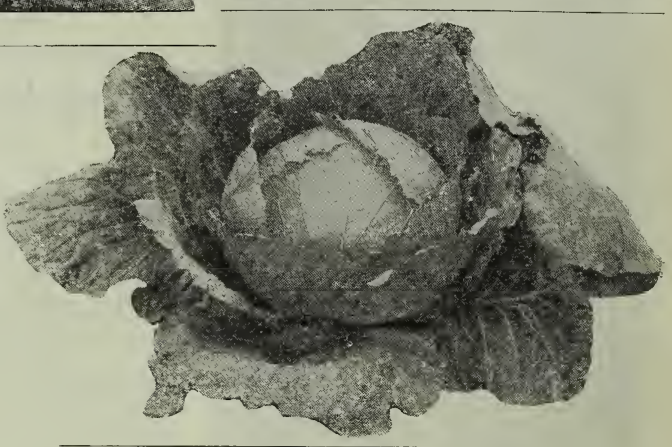

\section{"American King" Cabbage}

Introduced by us in 1904 , it has met with universal praise everywhere. Mammoth solid heads, weighing from 25 to 30 pounds are common sights in a field of this wonderful late Cabbage. We could not offer you anything better if we had the world's entire output of cabbage to select from. Its chief points of merit are in abso. lute reliability as a sure cropper, its uniformly large size of head, its great drought and 'worm-proof qualities. A very prominent and distinct feature of the AMERICAN KING has a small number of ribs and their remarkable smallmess in size. This stamps it of the highest quality. Price: Pkt., 10c; 1/2 oz., 20c: oz., 35e; $1 / 4$ lb., \$1.25. 


\section{Great International Cucumber}

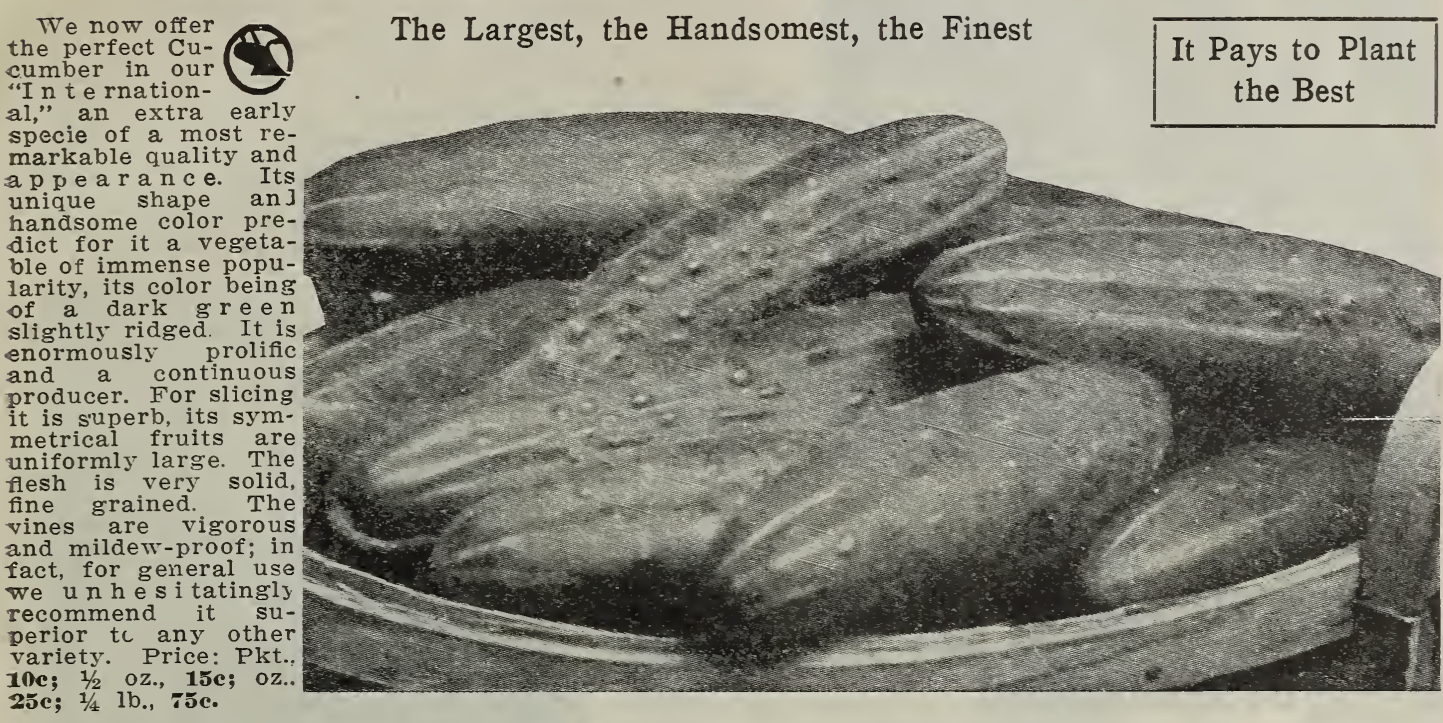

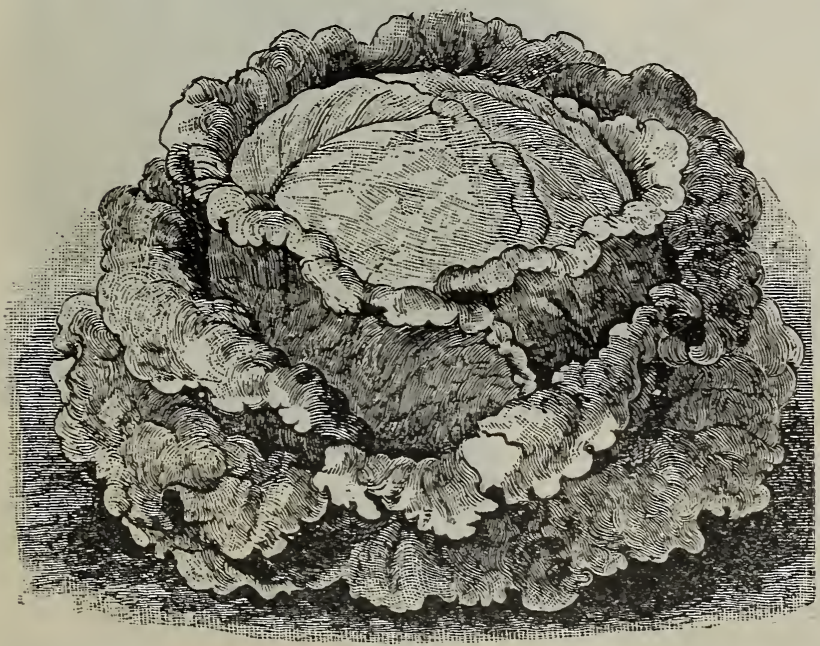

\section{Big M. G. Lettuce}

A Large, Handsome, Solid Head, Crisp and Tender.

It has required years of careful crossing and selection to bring this up to its present high standard. Our illustration shows its heading qualities to perfection.

Produces immense solid white heads. The ideal Lettuce for first sowing under sash, muinly for outdoor planting, either for early spring or fall planting. Unsurpassed as a market variety or for private garden. Very tender and possesses a deli. ciously rich, buttery flavor.

Prices: Pkt., 10e; $1 / 2$ oz., 15c; oz., 25c; $1 / 4$ $1 b ., 75 c$.

\section{King of the Garden Lettuce}

\section{A FINE HEAD VARIETY}

A fine variety for outdoor planting or for cold frames either for market or home use. It produces' extra large heads, very compact, of a fine flavor. It does not run up to seed as soon as others, nor turn a yellow color. It has been thoroughly tested in this locality and we highly recommend it to our customers. Our market gardeners should not fail to plant freely of it. Price: Pkt., 5c; $1 / 2$ oz., 10c; 1 oz., 15c; $1 / 4$ lb., 50c.

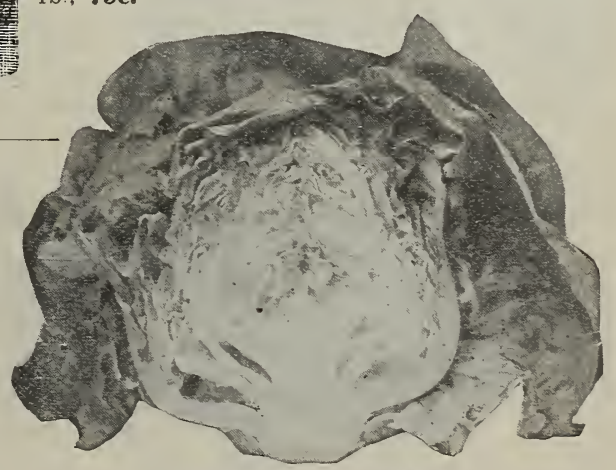

King of the Garden 


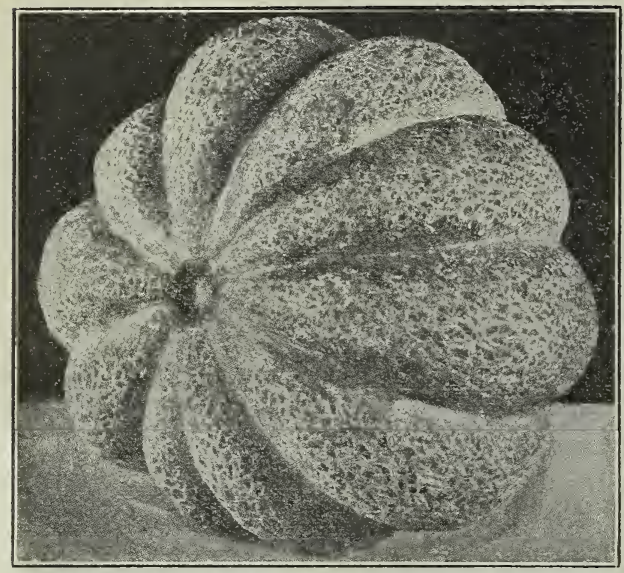

St. L. S. Co.'s Colorado Queen

A GRAND GREEN FLESH VARIETY

A GOOD MONEY-MAKER

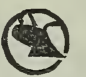

Here is the melon-the one we prophesied would become the leading muskmelon. Owing to its well-ribbed, heavily netted, compact form, it has proven to be one of the best shipping varieties, It grows larger than the Hackensack, almost round, being a trifle flat at the stem end. Its handsome appearance lar supersedes anything ever before seen in the muskmelon world, and will prove a bonanza to the market gardener. Price: Pkt., 5c; oz., 15c; $1 / 4$ lb., 50c.

St. L. S. Co.'s New Colorado Queen

\section{Monarch-of-the-West Muskmelon}

The Sweetest Melon that has Ever Been Offered to Melon Lovers

This muskmelon is the most delicious orange-flesh melon ever discovered. Extra early and an enormous cropper. All who have

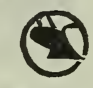
tasted it go into ecstasies over its rich flavor. In size it is large and perfect. (See cut.) The uniform size of the fruits make it a market favorite. The careful melon grower will make no mistake to devote a large share of his ground to this grand new variety. Its growth is remarkably fast, and of a very superior nature. It has an exceedingly small seed cavity, which alone would insure its remarkable goodness. The flesh is very deep, rich orange-flesh, ripening clear to the rind. Price: Pkt., 10c; $1 / 2$ oz., 15e; oz., 20c; $1 / 4$ lb., 60c.
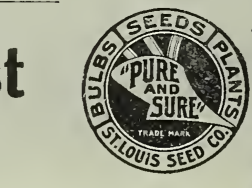

Nothing Better For Home Use

\section{Do you ever make a mistake?}

We do, but we are always ready to correct it.

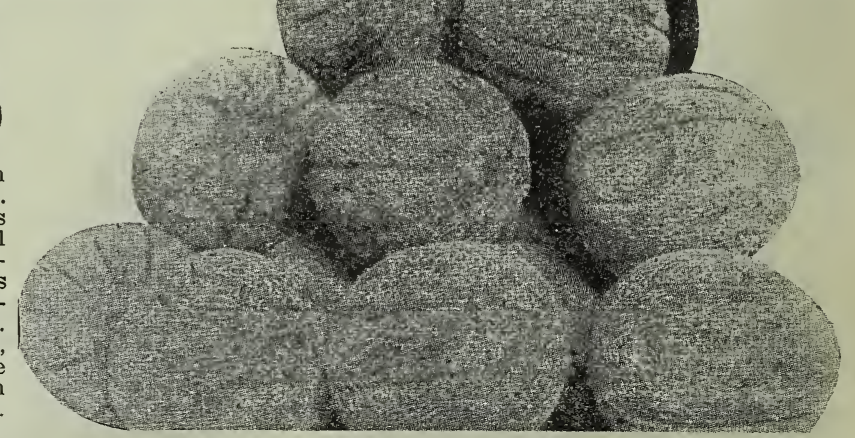

Monar h-of-the-West Muskmelon

THE EARTH OWES YOU A LIVING. "PURE AND SURE" SEEDS WILL MAKE IT PAY YOU.

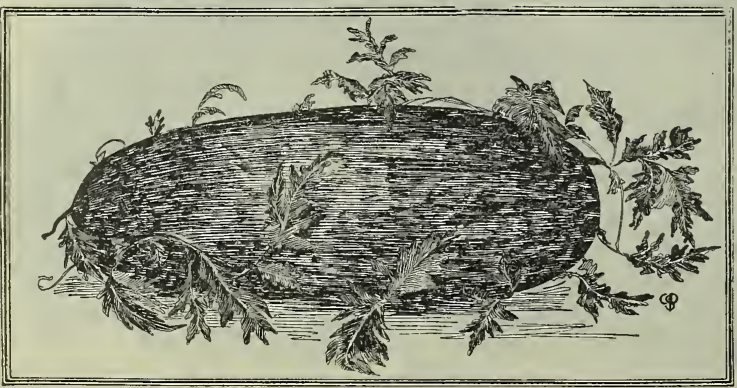

Tom Watson

\section{Watermelon}

A novelty in watermelons, and of sterling merit. It was introduced last season and has been quite extensively tried, so that it has passed its period of experiment. The fruit is very large, many melons weighing 50 to 60 pounds and measuring 18 to 24 inches in length. Its rind is very thin, but exceedingly tough, and on this account it is one of the very best shipping varieties. The skin is a dark mottled green, while the flesh is a brilliant scarlet, and the heart is very large with a small seed area. The flavor is most delicious and refreshing. Price: Pkt., 10c; oz., 15c; $1 / 4$ lb., 40c. 


\section{Nichol's Delight Pea}

Earliest of All Big-Podded Wrinkled Peas

Introduced by us, this mammoth Pea jumped into popular favor, in fact, we predict that the name and fame of this wonderful earliest of all big-podded, wrinkled varieties will go down in history as the marvel of the present age. While it is a second early, yet it matures almost as soon as the early varieties. It is sweeter in flavor than any pea we have ever seen. It is an enormous yielder and of robust growth. It is thoroughly acclimated. 'The handsome pods are always well filled and of uniform size and shape, there usually being from 10 to 15 peas to a pod. We are sure that everyone who tries this new Pea will be "delighted." Height, 3 feet. Price: Pkt., 10e; 1/2 pt., 15e; pt., 25e; qt., 40e.

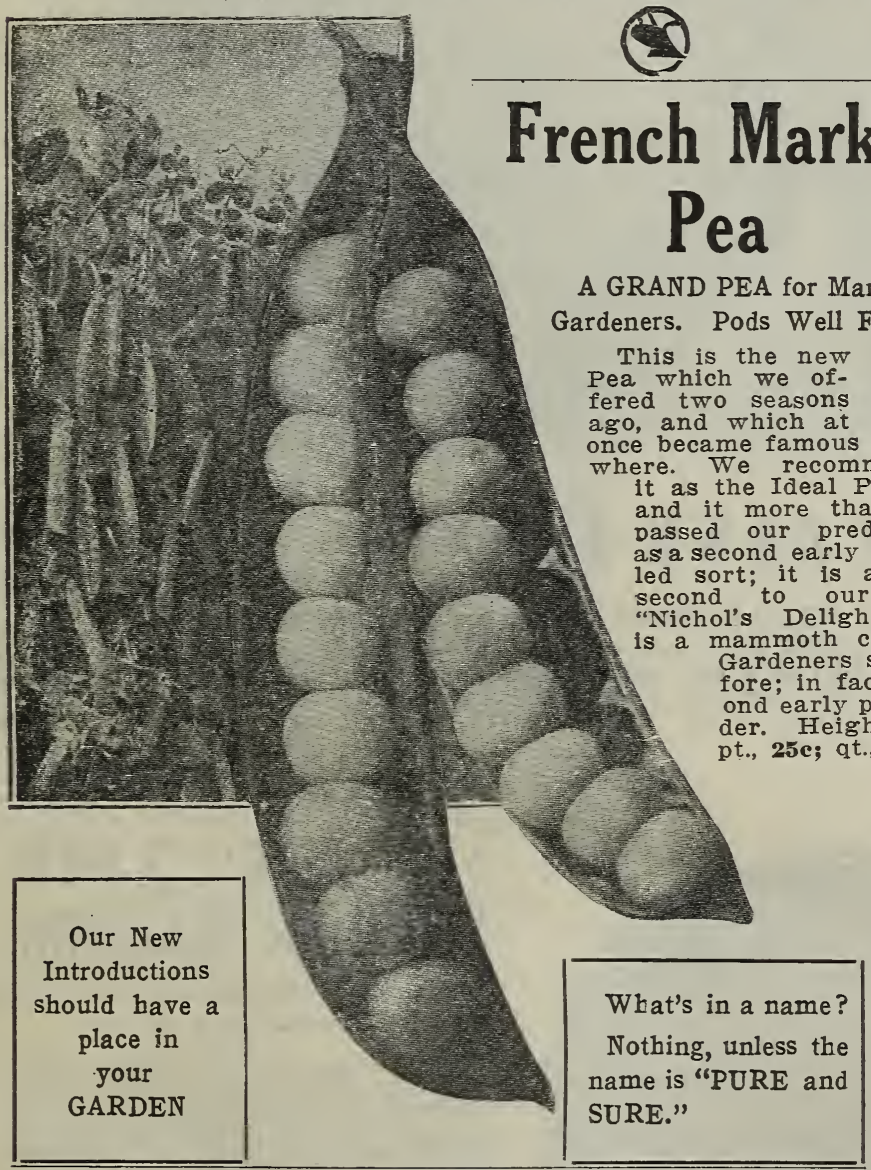

\section{St. L. S. Co.'s Fire Ball Radish}

it is a "Fire Ball" both in growth and appearance. Radishes 18 days from the time of planting is its record. Their beauty and crispness will demand fully 50 per cent higher price than any radish you have ever sold. Think what this means, "Fire Ball" is one of the most handsome radishes ever discovered. We consider ourselves extremely fortunate at being able to offer you such a magnificent forcing Radish, and it is now offered to the world as the "Best." If you are anxious to have radishes 8 to 10 days ahead of your neighbor, here is your opportunity. It's rich, crisp. brittle flavor, with its remarkably good growth and fine pinkish red color will make it a universal favorite. Price: Pkt., 10e; oz., 15e; 1/4 1b., 25e.

This is the New Pea That Has

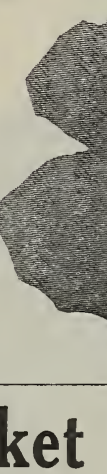
Made Good

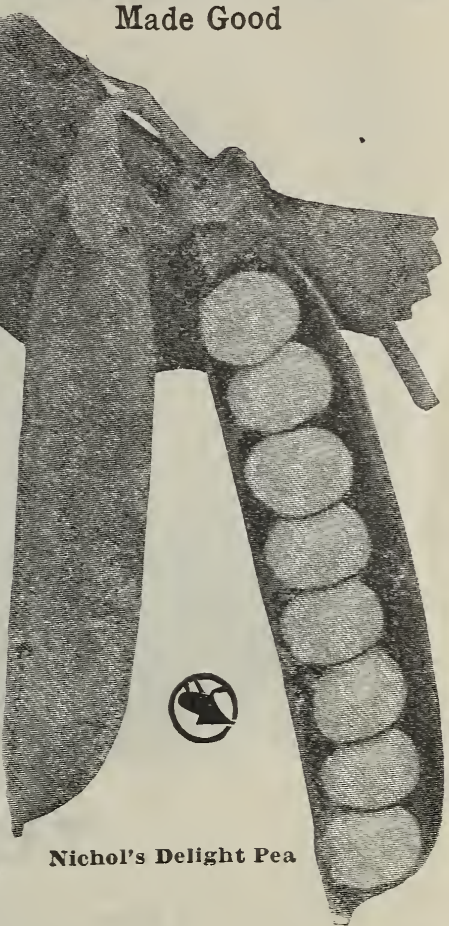




\section{A Grand New Tomato for Your Garden}

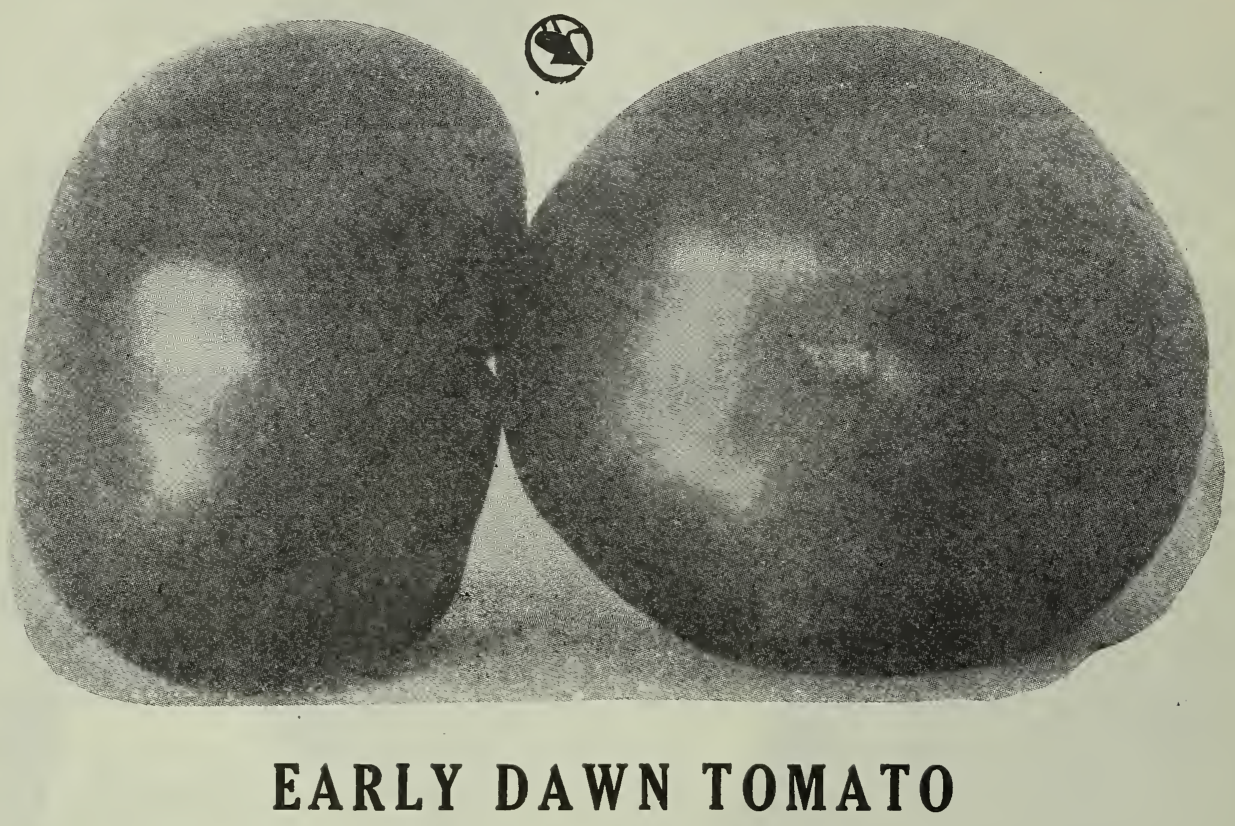

A New Tomato that will be a Money Maker for the Gardener

Its extra early qualities.combined with its perfect shape and productiveness will be sure to please everyone. As compared with Beauty, it will be a few days earlier and will average fully as large and ripens up quick. Its beautiful pink or purple color will attract all who raise it. We are well pleased with the past trials and have a Tomato here that will win first place. Price: Pkt., 10c; 1/2 oz., 20c; oz., 40c.

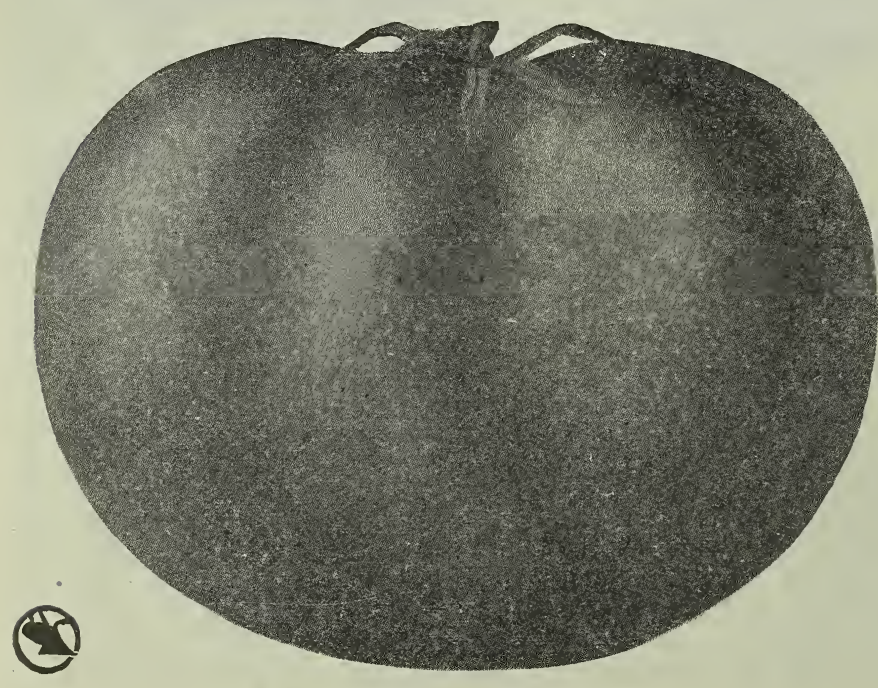

\section{ST. L. S. C0.'S NEW WONDER MAGNUS}

The Largest, Handsomest and Most Solid Harly Tomato in Existence.

The Tomato that has made more money for gardeners in every civilized country than any other new garden product ever discovered. This ideal Tomato, in richness', flavor and excellence is so much superior to any other known variety that there cannot begin to be any comparison. It is of a beautiful, deep, rich purple color, almost as solid as a rock, and contains very few seeds. For canning, slicing, cooking or serving in any way, its rich, appetizing flavor cannot be equaled. Its appearance will command almost double the market price, and it is a Tomato that will always be in big demand. We urge our customers and friends everywhere to plant freely ot the New Wonder Tomato this season. Price: Pkt., 10e; 1/2 oz., 15̄e; oz., 25e; 1/4 1b., 75 . 


\section{Asparagus (spargel)}

One ounce to 60 feet of driil. COLUMBIAN MAMMOTH WHITE-This variety is the most popular of the asparagus family. Very early and robust. Stalks are very thick, tender and succulent, and is, in fact, without exception, superior to any other known variety. Price: Pkt., 5e; oz., 10e; $1 / 4$ lb., 15c.

PALMETTO-A close second to our famous Columbian White Mammoth. An enormous yielder, very tender and appetizing, producing large, clear stalks of excellent quality. Very eafly. Price: Pkt., Je; oz., 10c; 1/4 1b., 15e.

\section{ASPARAGUS ROOTS}

COLUMBIAN MAMMOTH AND PALMETTO-Price: 2 year old, doz., 20c; 25 for 30c; 100 for 75e; 1000 for \$5.00. 1 year old, 100 for 50c; 1000 for \$4.00.

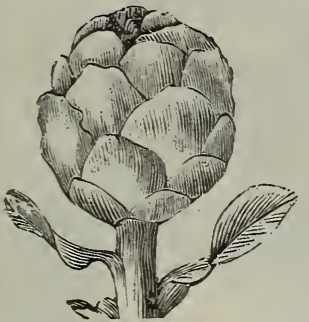

\section{Brussels Sprouts}

(Sprossen Kohl)

One ounce will produce about 5000 plants:

The very best winter vegetable. Frost seems to improve the delicious flavor instead of injuring. The plants may remain in the open ground until desired for cooking. Not surpassed by even the finest cauliflower.

ROSEBERRY-The choicest variety. Price: Pkt., Je; $1 / 2$ oz.. 10c; 1 oz.. 15e; $1 / 4$ lb.. 40c.

\section{Chicory (Cichorien)}

One ounce will sow about 15 square feet.

LARGE ROOTED-The finest flavored and hardiest growing variety. Price: Pkt., 5e; 0z., 10c; 1/4 Ib., 30c.

\section{Dandelion (Loewenzahn)}

One ounce will sow 200 feet of drill. Two pounds will sow an acre.

IUPROVED LARGE LEAVED-For oreens, which are cooked like mustard and spinach. Sow the

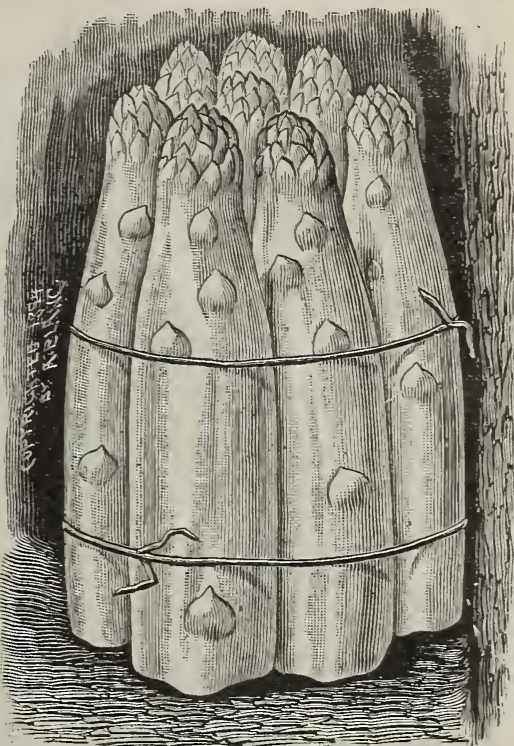

Columbian or Mammoth White

seed in May or June, will be ready to cut the following spring. Best cutting variety. Price: Pkt. 5e; $1 / 2$ oz., 25e; oz., 40e; $1 / 4$ lb., \$1.25.

\section{Collards}

One ounce will produce about 2500 plants.

A favorite in the South, where Collards are used extensively for "greens." Collards' grow in the form of a loose-headed cabbage.

GEORGIA or SOUTHERN-The standard sort for productiveness. Very hardy and appetizing. Price: Pkt., 5c; oz., 10c; $1 / 4$ ib., 25c.

\section{Corn Salad or Fetticus}

(Ackersalat)

One ounce will sow 100 feet of drill.

A favorite for early "greens." By sowing in the fall and protecting during the winter with leaves or straw, it can be gathered very early in the spring. However, if planted in April it is soon ready for use. Sow in rich, loamy soil, watering occasionally with warm water.

LARGE LEAVED-The hardiest, earliest and most appetizing variety grown. Price: Pkt., 5e oz., 10e; $1 / 4$ lb., 15e.

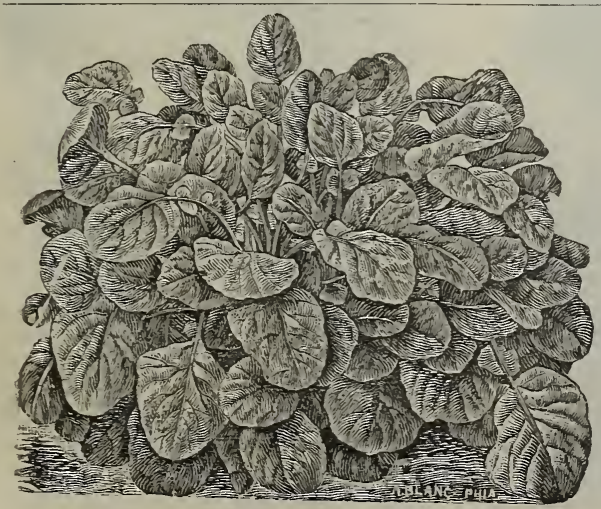

\section{Cardoon}

LARGE SPANISH-Large, fleshy-leaved plants, chiefly used as a winter vegetable. The blanched stalks and broad ribs of the inner leaves when properly cooked are tender and of an agreeable flavor. Price: Pkt., Je; $1 / 2$ oz., 10e; oz., 20e; $1 / 4$ ib., 50c.

\section{Cress (Kresse)}

Used for Salads and for Garnishings

Cress. One of the most useful plants for "greens" or salads. Should be sown in a hotbed or sheltered spot: sow quite thick in shallow drills, and in a short time it will be fit for cutting.

TRUE WATER-Thrives best in shallow water on the edge of streams. Price: Pkt., 5e; $1 / 2$ oz., 15c; Oz., 25e; $1 / 4$ 1b., 75 c.

CURLED-Peppergrass-This little salad will bear cutting several times; used mixed with lettuce its leaves impart an agreeable, warm and pungent taste. Price: Pkt., 5c; oz., 10c; $1 / 4$ lb., 15c. 


\section{DWARF OR BUSH}

(Busch Bohnen)

GREEN-PODDED VARIETIES

One quart will plant 100 feet of drill, $1 \frac{1}{2}$ bushels will plant

STRINGLESS G R E E N PODHandsomest and most prolific of all the stringless varieties. Pods are very large, round and meaty, and for market gardeners this variety is a money maker. Very early, a sure ket or home use. Price: Pkt., 5e $1 / 2$ pt., 10c; pt., 20c; qt., 30c.

ST. L. S. CO.'S GIANT STRINGLESS GREEN POD-An early large stringless variety, a good yielder. but not quite as good a quality as variety above. Price: Pkt., 5e; 1/2 pt., 10c; pt., 20c; qt., 30c.

ST. L. S. CO.'S EXTRA EARLY RED VALENTINE-For earlinesS, productiveness and appetizing quality, it surpasses any other known Podded Bush variety. It is' a strain that we highly recommend. Price:

THE NEW BOUNTIFUL-See Nov-

\section{elty Page 1. \\ LONGFELLOW BEAN}

In fact we doubt if ever a better greenpodded bush variety will be discovered; say what we may, we cannot estimate the many good qualities of our private strain of Longfellow. Its handsome, straight, fleshy, solid pods averaging from 6 to 7 inches in length together with its captivating, delicious' flavor, make it a bean so much in demand that gardeners have been unable to supply the trade. Owing to its extra earliness, it is ready for market fully a week before its nearest rival.

Price: Pkt., 5c; $1 / 2$ pt., 10c; pt., 20c; qt., 30c.

WHITE NAVY - The famous little white soup bean that needs no further introduction. Very prolific and a sure cropper. Price: Pkt., sc; $1 / 2$ pt., 10c; pt., 20c; qt., 30c.

\section{WAX-PODDED BUSH BEANS}

ST. L. S. CO.'S PENCIL POD BLACK WAX-Of all Black Wax Beans, this variety surpasses all others. It comes in season with the regular wax sorts, but remains in picking condition much longer. For Market Gardeners as well as for home use it cannot be surpassed. Price: Pkt., 5c; 1/2 pt., 10c pt. 20c; qt., 35c.

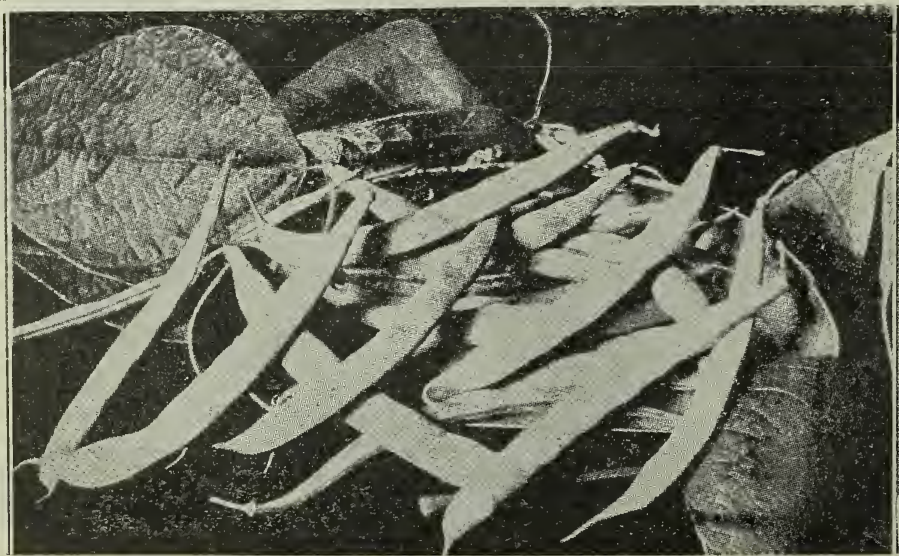

DAVIS WHITE WAX-This famous Snap Bean is of a very hardy and productive nature; of handsome appearance and entirely rust-proof: pods grow long, straight and waxy white, with a crispness, when cooked, that is simply delicious. Price: Pkt., 5c; 1/2 pt., 10c; pt., 20c; qt., 35c.

IMPROVED GOLDEN WAX-An ideal variety, similar to the above; very productive; should be used while young. Price: Pkt., 5c; $1 / 2$ pt., 10c; pt., 20c; qt., 35c.

PROLIFIC GERMAN BLACK WAX-This famous bean is too popular to need any introduction. Until the recent introduction of our celebrated "Pencil Pod" Bean it was looked upon by many as the sitlandard. It is very prolific, and for an early market variety it is hard to surpass. Price: Pkt., 5e; $1 / 2$ pt., 10c; pt., 20c; qt., 35c.

WARDWELL'S KIDNEY WAX-Undoubtedly the standard of all late varieties. Used extensively for marketing purposes. Pods grow very large, are broad and of a striking color. Price: Pkt., 5c; $1 / 2$ pt., 15c; pt., 25c; qt., 40c.

NEW WHITE WAX-See page 


\section{BUSH LIMA BEANS}

HENDERSON'S BUSH LIMA-A famous new variety, grows in compact bush form and produces enormous yields of truly delicious Lima Beans, yielding a continuous crop from July until frost appears. Earlier than Burpee's. P'rice: Pkt., 5c; 1/2 pt., 10c; pt., 20c; qt., 35c.

BURPEE'S BUSH LIYA-A true bush form, growing 18 to 20 inches high; an Immense yielding variety, each bush being laden down with very large beans of luscious flavor. Price: Pkt., כe; $1 / 2$ pt., 10c; pt., 20c; qt., 35c.

ST. L. S. CO.'S NEW BUSH LIMA-Se page 2 .

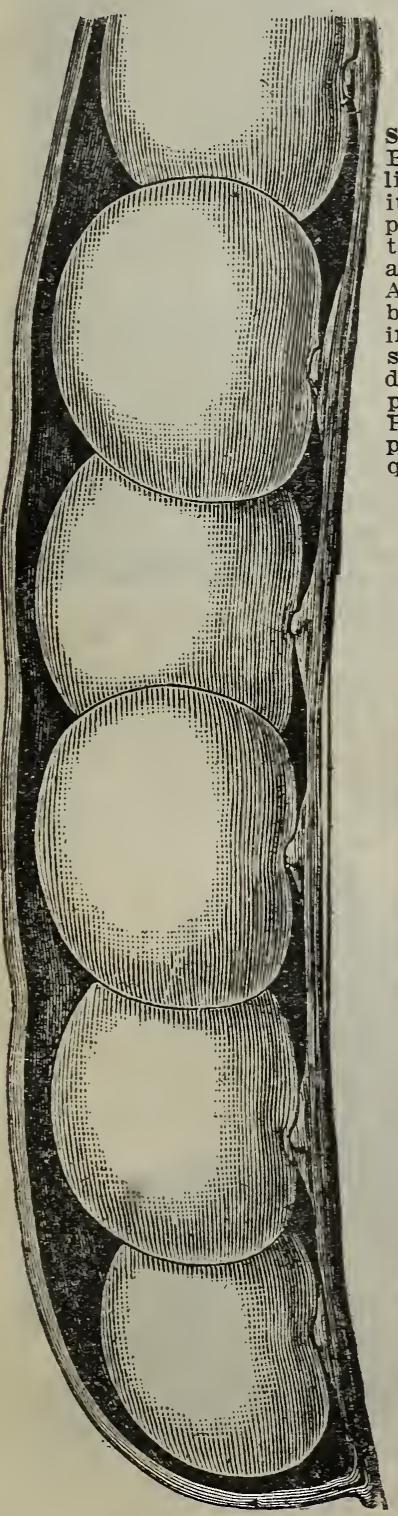

English Bean BROAD WINDSOR (English Bean)-The Englishman's favorite, grown and prized in their native land as much as the Lima is in America. Should be planted early in a rich, loamy soil. Is of a very delicious and appetizing flavor. Price: Pkt., 5e; $1 / 2$ pt., 20c; pt., 30c; qt., 50c.

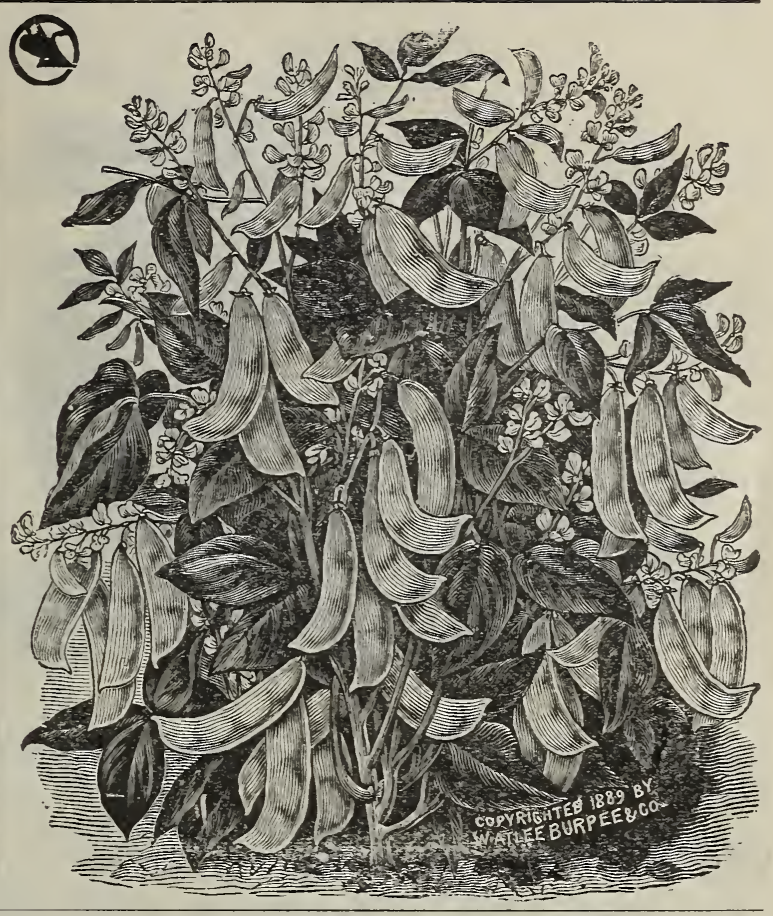

\section{POLE LIMA VARIETIES}

NICHOL'S GENUINE BUTTER BEAN-We offered these old-time favorites for the first time three seasons ago, and the demand has since grown phenomenal. Remember, it is the original old-time Butter Bean so much sought after by our parents and grandparents years ago. Vines grow very vigorously and are laden with mammoth wide pods, containing from 3 to 5 beans each. They are the genuine old-time Butter Bean Price. Pkt., 5c; $1 / 2$ pt., 15c; pt., 25e; qt., 40c.

ST. L. S. CO.'S KING OF THE GARDEN LIMA-A great improvement on the large White Lima Beans; grow of an enormous size, an immense yielding sort. Price: Pkt., 5c; $1 / 2$ pt., 10c; pt., 20c; qt., 35c.

EXTRA EARLY JERSEY LIMA-The earliest Lima Bean in existence. being about two weeks earlier than other varieties. P'rice: Pkt., $5 c ;$ $1 / 2$ pt., 10c; pt., 20c; qt., 35c.

\section{BEANS, POLE OR RUNNING}

(Stangen Bohnen)

One quart will plant 150 hills.

MISSOURI WHITE CORNFIELD-A fine Iong, green, round pod of superior quality. Beans are white and mealy, a fine boiling or baking variety. Grown quite extensively for market gardening and home use. Price: Pkt., Jc; 1/2 pt., 10c; pt., 20c; qt., 35c.

DUTCH CASE KNIFE-One of the best varieties, whether used as a snap sort or shelled. Pods grow very large, flat and of excellent quality. Price: Pkt., 5c; 1/2 pt., 10c; pt., 20c; qt., 30c.

LAZY WIFE-The pods are of a medium dark green color and grow from 5 to 7 inches in length. They are broad, thick and very fleshy, and are entirely stringless. Price: Pkt., 5c; $1 / 2$ pt., 10c; pt., 20c; qt., 35c.

KENTUCKY WONDER, OR OLD HOMESTEAD-Undoubtedly the earliest and most productive, bearing in great quantities clusters of light green pods, long, meaty and of excellent flavor. Can be grown with corn to good advantage. Price: Pkt., 5c; 1/2 pt., 10c; pt., 20c; qt., 35c.

WHITE CREASEBACK-A pure white variety, very early, and an excellent shelled sort used extensively for winter use. P'rice: Pkt., 5c; $1 / 2$ pt., 10c; pt., 20c; qt., 35c.

RED SPECKLED CUT SHORT-The most popular sort for country planting, being an ideal variety for planting in corn fields. Price: Pkt., 5c; 1/2 pt., 10c; pt., 20c; qt., 30c.

NEUV WHITE CORNFIELD-See page 2. 


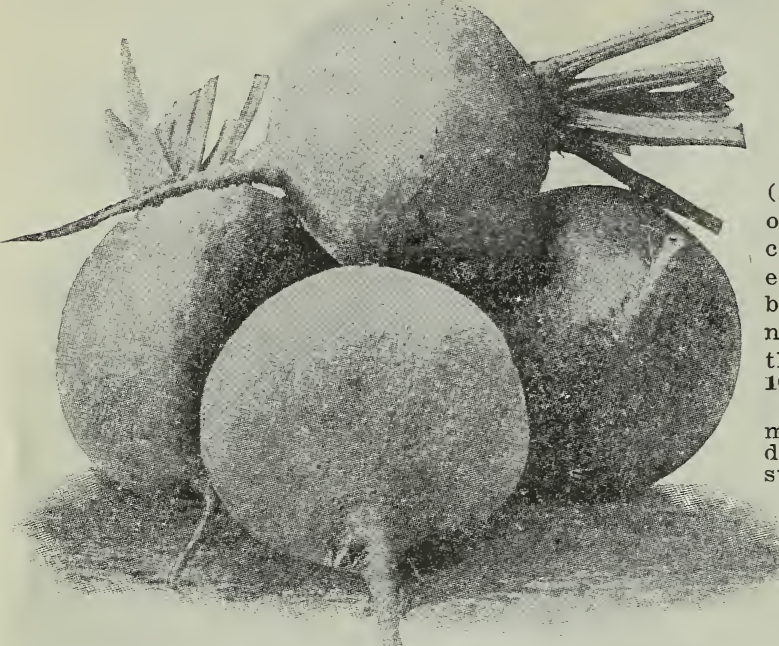

\section{Beets :(Rothe Rucbe)}

One ounce will sow 50 feet of drill. Five pounds will sow 1 acre of drill.

ST. L. S. CO.'S NEW CROSBY EGYPTIAN (American grown)-This famous strain of our own production is undoubtedly, without an exception, one of the finest, as well as one of the earliest beets ever grown, its' shape and color being superb. Gardeners from all directions do not hesitate to pronounce this wonderful variety the "King of all Beets." Price: Pkt., 5c; oz., 10c; $1 / 4$ lb., 20c.

ST. L. S. CO'S CRIMSON GLOBE-Grows of medium size, .very handsome in shape, a little deeper than round, with a remarkably smooth surface. Price: Pkt., 5c; oz., 10c; $1 / 4$ lb., 20c.

IMPROVED LONG SMOOTH BLOODPlanted extensively for late fall and winter use. Price: Pkt., 5c; oz., 10c; $1 / 4$ 1b., 20c.

EARLY EGYPTIAN-One of the most popular flat-shaped varieties; early. Price: Pkt., 5e; oz., 10c; 1/4 1b., 20c.

DIETROIT DARIK RED-One of the good early turnip-shape varieties, too well known to need any further commient. Price: Pkt., 5e; oz., 10e; $1 / 4$ 1b., 20c.

EDMUND'S-This celebrated variety is strictly a market beet Very popular for late planting. Price: P'kt., 5c; oz., 10c; $1 / 4$ lb., 20c.

ECLIPSE-A famous standard variety in all points of value and merit; as a first early market beet this ranks with the Crosiby Egyptian. It is a favorite $€$ verywhere. Price: Pkt., 5c; oz, 10e; 1/4 Ib.; 20c.

SWISS CHARD-A silver colored beet, different from all the rest. Tops are much superior to common varieties for greens when cooked quite young.
Later they may pe prepared like asparagus. Grown extensively by truckers and gardeners to supply their "greens" trade. Very popular. Price: Pkt., 5e; 0z., 10c; $1 / 4$ 1b., 15c.

\section{STOCK MANGELS}

GOLDEN TANKARD-The best yellow for stock feeding. Price: 1 oz., 5c; $1 / 4$ lb., 15c; $1 b ., 35 c$.

MAMMOTH LONG RED-(Norbiton Giant or Jumbo Mangel)-Enormous and of fine quality. P'rice: 1 oz., 5c; $1 / 4$ lb., 15c; lb., 35c.

VILMORIN'S IMPROVED-The best variety for producing sugar. Price: Oz., 5e; $1 / 4$ lb., 10c; lb., 25c.

\section{Carrots (molue}

One ounce will sow 100 feet of drill. Three 1bs. will sow an acre.

DANVER'S HALF LONG-The leading "standard variety. Flesh is of a dark orange color, very tender and appetizing: roots are of a medium length and taper proportionately; very sweet and productive. Price: Pkt., 5c; oz. 10c; 1/ ib. 25c.

OXHEART-(Guerande)-A beautiful, short, thick stump-rooted variety. The roots are very smooth and cylindrical; meat of a delicious bright orange color; in fact, it is an ideal summer variety in every respect. Price:

Pkt., 5c; oz., 10c; $1 / 4$ lb., 25c.

HALF LONG SCARLET STUMP-ROOTED-One of the finest carrots ever grown; an exceilent market variety. Medium early and of medium size. Price: Pkt., 5c; oz., 10c; 1/4 lb., 25c.

IMPROVED LONG ORANGE-Large, sweet, thick and tender, an immense yielder and an ideal variety for both table and stock feeding. Price: Pkt. כe; oz., 10c; 1/4 1b., 25c.

ST. VALERY - In our new private strain of $\mathrm{St}$. Valery we offer you one of the best. For stock as well as for table use it cannot be surpassed. In size it is large, being from 10 to 12 inches in length, and 2 to 3 inches in diameter. Rich, deep orange in color. Price: Pkt., 5e; oz., 10c; $1 / 4$ 1b., 25e.

LONG ORANGE STUMP-ROOTEDThis is a fine new variety of good color and shape; will take well with the market garden trade; will outclass any other long variety. Price: Pkt., 10c; oz., 15c; $1 / 4$ lb., 35c.

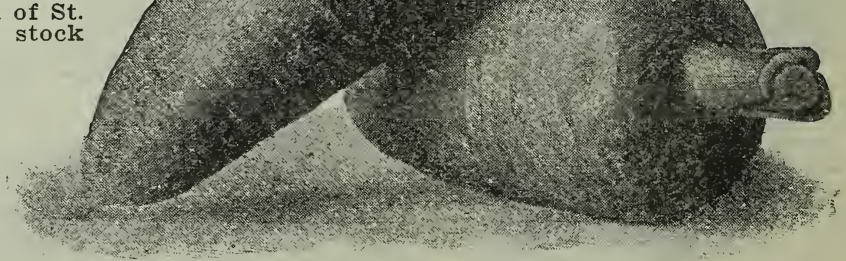



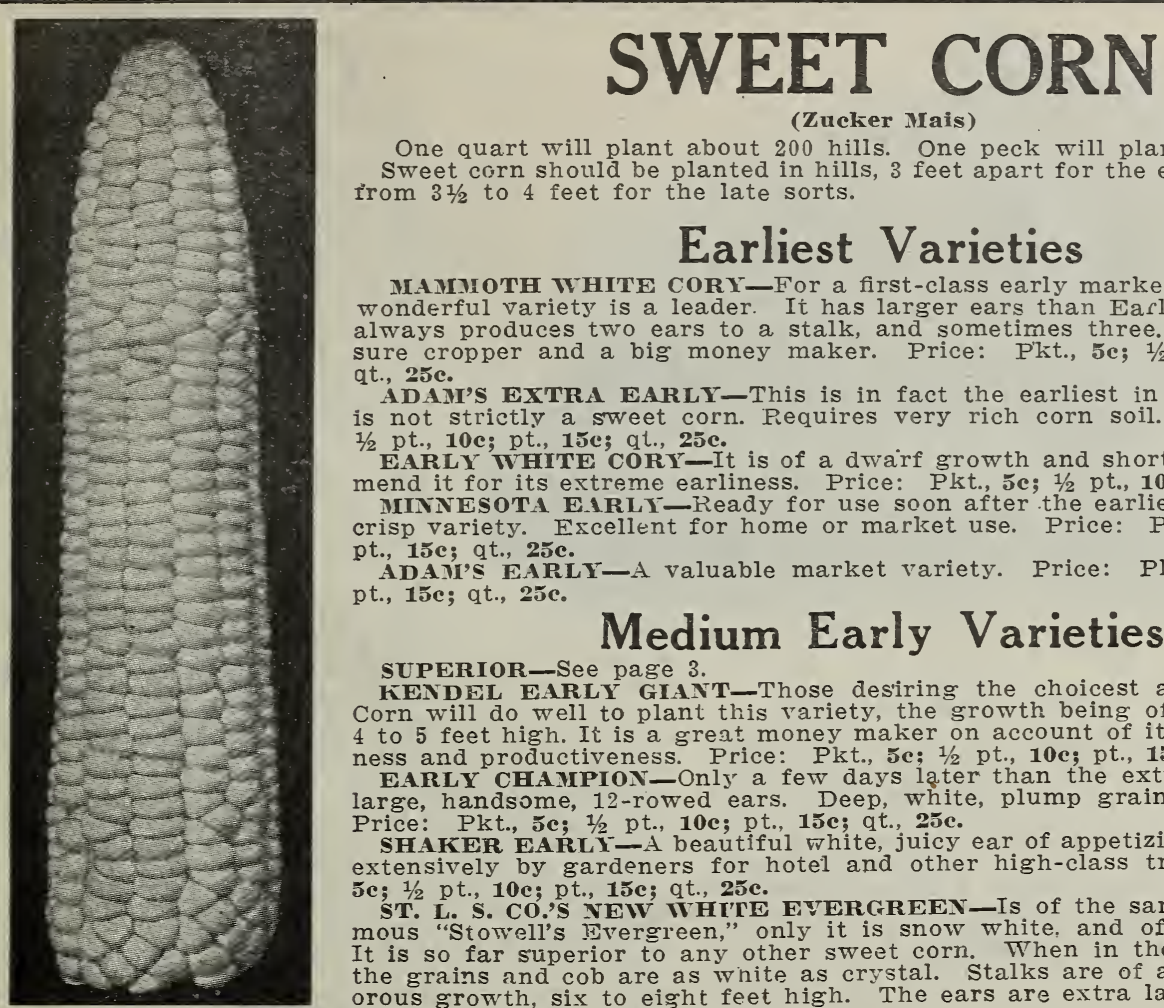

(Zucker Mais)

One quart will plant about 200 hills. One peck will plant about 1 acre.

Sweet corn should be planted in hills, 3 feet apart for the early rarieties, and Irom $3 \frac{1 / 2}{}$ to 4 feet for the late sorts.

\section{Earliest Varieties}

MAMUOTH WHITE CORY-For a first-class early market or home use, this wonderful variety is a leader. It has larger ears than Easly White Cory, and, always produces two ears to a stalk, and sometimes three. Twelve rowed, a sure cropper and a big money maker. Price: Pkt., 5e; 1/2 pt., 10c; pt., 15c; qt., 25c.

ADAN'S EXTRA EARLY-This is in fact the earliest in cultivation, but it is not strictly a sweet corn. Requires very rich corn soil. Frice: Pkt., Jc: $1 / 2$ pt., 10c; pt., 15e; qt., 25e.

EARLY WHITE CORY-It is of a dwarf growth and short ears. Te recommend it for its extreme earliness. Price: Pkt., 5c; 1/2 pt., 10c; pt., 15c; qt., 25c.

MINNESOTA EIRLT-Ready for use soon after the earliest Cory. A sweet, crisp variety. Excellent for home or marlzet use. Price: Pkt., əc; 1/2 pt., 10c; pt., 15e; qt., 25e.

ADAI's EARLY-A valuable market variety. Price: Pkt., sc; 1/2 pt., 10e: pt., 15c; qt., 25̃c.

\section{Medium Early Varieties}

SUPERIOR-See page 3

KFYDL FARLY GINT-Those desiring the choicest and earliest Sweet Corn will do well to plant this variety, the growth being of a dwarf nature4 to 5 feet high. It is a great money maker on account of its earliness, sweetness and productiveness. Price: Pkt., 5c; $1 / 2$ pt., 10c; pt., 15e; qt., 25c.

EARLY CHAMPION-Only a few days later than the extra earlies, bearing large, handsome, 12-rowed ears. Deep, white, plump grains and very sweet. Price: Pkt., כe; 1/2 pt., 10c; pt., 15e; qt., 25e.

SHAKER EARLY - A beautiful white, juicy ear of appetizing quality. Grown extensively by gardeners for hotel and other high-class trade. Price: Pkt., כe; $1 / 2$ pt., 10e; pt., 15e; qt., 25e.

ST. L. S. CO', S NEW WHITE EVERGREEN-Is of the same type as the famous "Stowell's Fvergreen," only it is snow white, and of excellent quality. It is so far superior to any other sweet corn. When in the green state both the grains and cob are as white as crystal. Stalks are of a very strong, vigorous growth, six to eight feet high. The ears are extra large. Price: Pkt., 5c; $1 / 2$ pt., 10c; pt., 15e; qt., 25c.

STOWELL'S EVERGREEN-Too well known to need any introduction. Ears are of a good size, with a deep, luscious, appetizing kernel. Price: Fkt., 5e; 1/2 pt., 10c; pt., 15c; qt., 25c.

COUNTRY GENTLEMAN-(See cut.) For a delicious', appetizing sweet corn this variety can not be surpassed. Its lus'cious quality makes it a favorite everywhere. Ears grow eight or ten inches long with a very small cob. Price: Pkt., 5c; 1/2 pt., 10c; pt., 15e: qt., 30c.

MAMMOTH LATE-This celebrated variety produces one of the largest ears of any sweet corn, a little later than "Stowell's Evergreen," but equally as good. Price: Pkt., 5e; 1/2 pt., 10e; pt., 15e: qt., 25c.

\section{CELERY}

GOLDFN SELF-BLANCHING-This is undoubtedly the finest celery in cultivation. Grows about 18 to 20 inches in height, unusually stocky and heavy. Straight, vigorous stalks of beautiful appearance and delicious flavor. A good keeper, always very brittle and teuder. Price: Pht., 10e; $1 / 2$ oz., 30c; oz., 50e; $1 / 4$ lb., \$2.00.

GOLDEN HEART-Very fine. When blanched the heart is of a beautifui, waxy, golden yellow color. Very showy and attractive. Dwarf. Price: Pkt., 5e; 1/2 oz., 15e; oz., 25e; 1/4 1b., 75e.

WHITE PLUME-One of the most desirable home garden varieties. Is earlier than Golden Self-Blanching, but is white instead of yellow. This famous variety is popular for the smaller home garden. Also very brittle, tender. Price: Pkt., 5c; 1/2 oz., 15c; oz., 25c; $1 / 4$ lb., 75c

CURLED CELERY-This new variety is used by gardeners for cutting and bunching; used to make soup, etc. Price: Pkt., 5e: 1/2 Oz., 15c; oz., 25c.

\section{CELERIAC (Knoll Cellerie)}

\section{Turnip Rooted Celery}

GIANT PRAGUE-This celebrated variety is the largest, smoothest and best strain of the Celeric family. Price: Pkt., 5e; $1 / 2$ oz., 10c; oz., 15e; 1/4 1b., 45e.

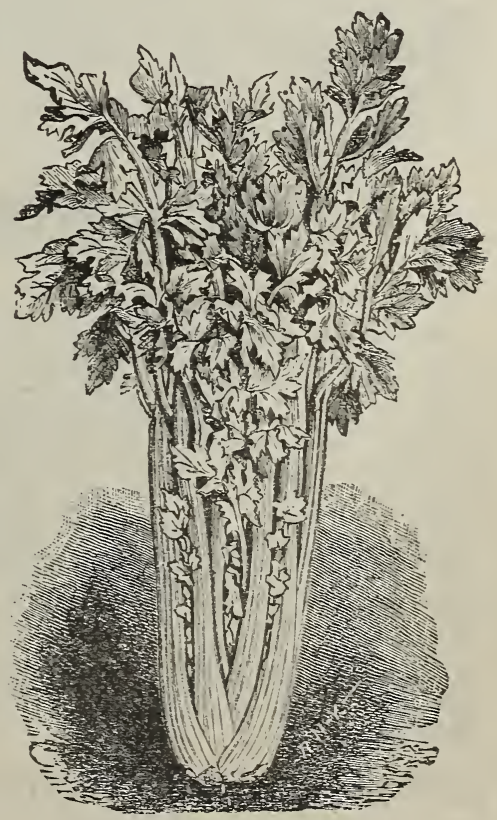




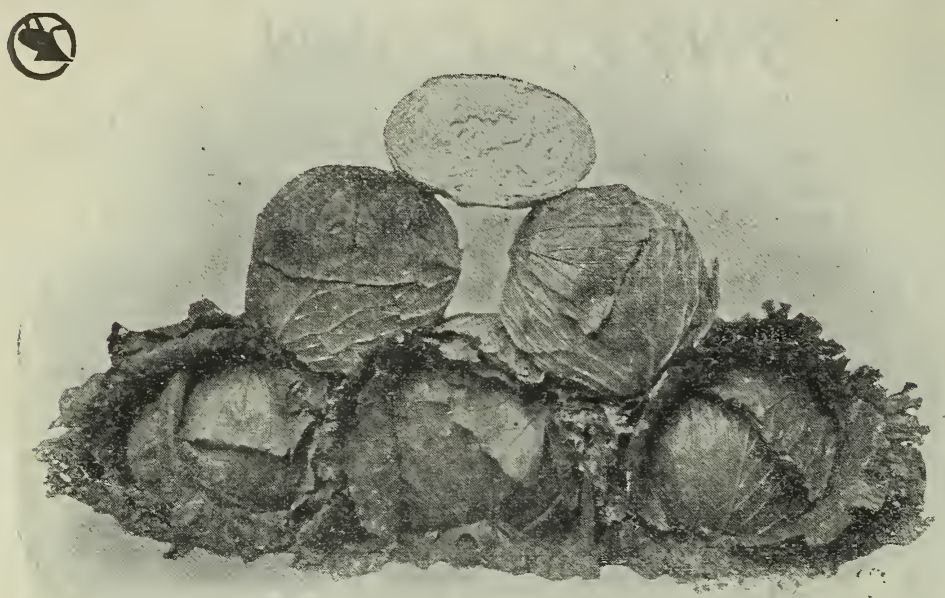

\section{Cabbage}

NICHOL'S NEW EARLY TOP.NOTCH

This is superior to any other varieties, both in earliness and productiveness; in fact, it is the most important addition made to the cabbage family in recent years-beautiful, large, round, solid heads of superior quality, idolized everywhere as being the "King" of all cabbages.

Price: Pkt., 10c; 1/2 oz., 25c; oz., 40c; $1 / 4$ lb., \$1.25.

ST. L. S. CO.'S EARLY JERSEY WAKEFIELD-This is our own private stock. This is a close second to our famous Top-Notch. Price: Pkt., 5e; $1 / 2$ oz., 10c; oz., 20 ; $1 / 4$ lb., 65e.

EARLY SPRING-Heads are of round, flat type. Matures almost as early as Wakefield. As it is a close header, the plants can be set very close together in the field. Price: Pkt., 5c; $1 / 2$ oz., 15e; oz., 25e; $1 / 4$ lb., \$1.00.

CHARLESTON LARGE WAKEFIELD-A few days later, but larger heads than Jersey Wakefield. Same general shape. Price: Pkt., 5e; $1 / 2$ oz., 10e; oz., 20e; $1 / 4$ lb., 65e.

ALL HEAD EARLY-An extra fine selection of Early Flat Dutch. Too well known to need any further commendation. Price: Pkt., 5e; 1/2 oz., 10c; oz., 20c; $1 / 4$ lb., 50e.

IMPROVED BRUNSWICK-Also known as Fottler's Early Drumhead. Ours is the true short-stem strain. Good for second early and late crop, and attains an extraordinary large size. Price: Pkt., 5c; $1 / 2$ oz., 10c; Oz., 20c; $1 / 4$ lb., 65c.

HENDERSON'S EARLY SUMMER-Always popular with market gardeners, as heads are twice as large as Wakefield and only twelve days to two weeks later. Frice: Pkt., 5e; $1 / 2$ oz., 10c; oz., 20c; $1 / 4$ 1b., 75c.

ALL SEASONS OR SUREHEAD-This is certainly well named, as it is a sure header of the Flat Dutch type of heads, and a first-class main crop sort. Price: Pkt., 5c; $1 / 2$ oz., 10e; oz., 20c; $1 / 4$ lb., 50c. PERFECTION LATE SAVOY-The heads are large and very solid and possess a fine, delicate flavor. The beautifully curled and crimped leaves are of a dark, rich green color. Price: Pkt., 5e; $1 / 2$ oz., 10e; oz., 20c; $1 / 4$ lb., 65e.

\section{Cauliflower}

(Blumen Kohl)

One ounce of seed produces about 3000 plants.

PRIDE OF DENMARK-(See Novelty page 4)-This is the highest standard of perfection. See description.

ST. L. S. CO'S NEW WHITE BEAUTYThe earliest, the largest and the quickest growing Cauliflower in existence. So pure and white in color, early and solid in forming. Price: Pkt., 25c; 1/4 Oz., \$1.00; 1/2 oz. $\$ 2.00 ;$ oz., \$4.00.

ST. L. S. CO'S EARLIEST DWARF ERFURT IXTTRA SELECT-Very early and a sure header, an ideal forcing variety and a valuable sort for early market or home use. Price: Pkt., 25c; $1 / 4$ oz., \$1.00; $1 / 2$ oz., \$2.00; OZ., \$3.50.

EARLY SNOWBALL-A favorite variety, produces magnificent white heads of fine quality. Price: Pkt., 15e; $1 / 40 z$., 75c; $1 / 20 z$., $\$ 1.25 ;$ oz., \$2.00.
MAMIIOTH ROCKRED-This famous variety is grown extensively almost everywhere. Heads are of a mammoth size, very solid and a sure cropper. Price: Pkt., 5c; 1/2 oz., 15c; oz., 25e.

AMERICAN KING-(See Novelty Page 4)-This is our famous cabbage for late fall and winter use.

SUPERIOR LA'TE FLAT DUTCH-The heads' are large and very solid; open white, are crisp and tender, and sure to head. Price: Pkt., 5e; $1 / 2$ oz., 10c; oz., 15c; $1 / 4$ 1b., 40c.

ST. LOUIS LATE MARKET-For regularity in growth and sure heading this variety can't be beat. Is of a handsome color and appearance; mammoth in size, delicious in quality, extra short stem and compact in growth. In fact, it is one of the largest and best late cabbages ever discovered. We control and own the entire stock of this record smashing variety. No matter what you see listed, no matter what you see described, our St. Louis Late Market will eclipse it 10 to 1 . Price: Pkt., 10c; $1 / 2$ oz., 20c; oz., 35e; $1 / 4$ lb., \$1.00.

ST. L. S. CO'S DRY WEATHER-This variety can be grown in dry locations and will make fine large compact heads. Our best variety for outdoor planting. Price: Pkt., 15c; 1/4 oz., 90c; 1/2 oz., \$1.75; 0z., \$3.00.

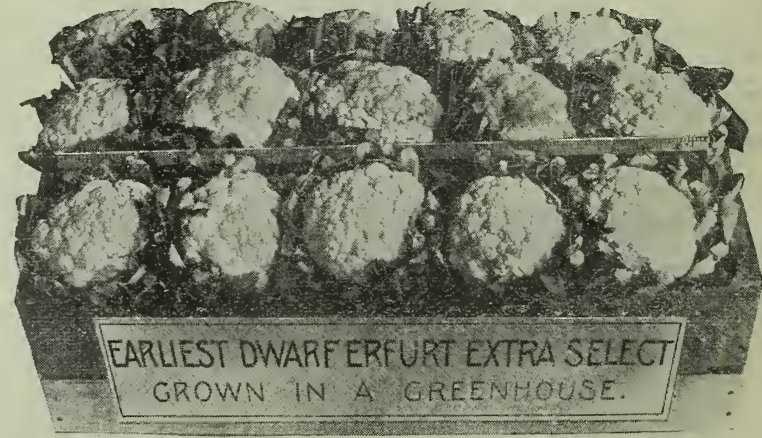




\section{CUCUMBER (Gurke)}

One ounce will plant about 50 hills; one to two pounds to the acre.

EARLY WHITE SPINE, OR PEERLESS-One of the best sorts to slice for the table. Our select strain of this well-known and popular variety is unsurpassed for the table and market. Grows 8 to 9 inches long. Price: Pkt., 5c; $1 / 2$ oz., 10c; oz., 15e; $1 / 4$ lb., 35c.

NICHOL'S "GREEN BACK"-It is of medium early growth and an immense yielder, and of the finest flavor. Vines produce an enormous crop. with large, thick, heavy leaves, thus insuring them almost bug proof. The handsome fruit grows to a length of from 12 to over 28 inches, and is of a most handsome, dark green type. The flesh is of a white, crisp quality, bringing extra high prices on the market. Price: Pkt., 5c; $1 / 2$ oz., 10c; oz., 20c; $1 / 4$ lb., 50c.

ARLINGTON IMPROVED WHITE SPINE-EXcellent for forcing or out-of-doors. A good seller on the market and a very profitable sort to grow for shipping. Price: Pkt., 5c; oz., 10c; $1 / 4$ lb., 25e.

ST. L. S. CO.'S EXTRA LONG IVHITE SPINE, OR EVERGREEN-It is certainly one of the handsomest as well as the most delicious varieties in the world. Grows from 10 to 14 inches in length. For hotels and restaurants, as well as the home table it cannot be surpassed. Price: Pkt., 5c; 1/2 oz., 10c; Oz., 15e; $1 / 4$ 1b., 35c.

LONDON LONG GREEN-The standard of all long green varieties. Nearly as early as the shorter varieties and grows to 12 inches long. Price: Pkt., 5c; $1 / 2$ oz., 10c; oz., 15c; $1 / 4$ lb., 35c.

\section{HERBS}

The varieties marked an asterisk (*) are hardy perennials. To preserve herbs properly, cut the stems and leaves just as the plant is coming into bloom, dry them in the shade, and when perfectly dry wrap them up in paper and store them away in a dry room, or rub the leaves to a powder, pack in bottles and cork tightly, and store them away, which will preserve them for any period.

ANISE-Seeds aromatic and carminative. Price: Pkt., 5e; oz., 10c.

BALM-For balm tea or balm wine. Price: Pkt., 5c; $1 / 2$ oz., 10; oz., 20c.

BASIL, SWEET-For highly seásoned dishes, soups, $\in$ tc. Price: Pkt., 5c; $1 / 2$ oz., 10c; oz., 20c.

BENE-Leaves good for diar-

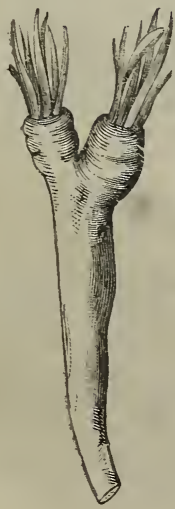
rhoea; seeds an oil for the skin Price: Pkt., 5c; $1 / 2$ oz., 10c; oz., 15c. BORAGE-Used as a salad. Pirice: Pkt., 5c; $1 / 2$ oz., 10c; oz., 15c.

*CATNIP, OR CATMINT-Leaves for seasoning. Price: Pkt., 5c; $1 / 2$ oz., 10c; oz., 20c.

*CARA IVAY_For flavoring bread. Price: Pkt., 5c; oz., 10c.

CHERVIL, CURLED-L a rge 1 y used in soup. Price: Pkt., 5c; $1 / 2$ oz., 10e; oz., 15e.

CORIANDER- $F$ or fl a voring cakes, etc. Price: Pkt., 5c; $1 / 2$ oz. 10e; oz., 15e.

HORSERADISH ROOTS-T h e soil should be very rich and well cultivated. Doz., 15c; 25 for 25c; 100 for $60 \mathrm{c} ; 1000$ for $\$ 4.00$
JAPANESE CLIMBING-If you cannot spare the space in your garden for cucumbers to sprawl around on the ground, plant this variety and train up vines to poles or trellises. Good for table use as well as pickling; 8 to 10 inches long. Price: Pkt., 5c; $1 / 2$ oz., 10c; oz., 20c; $1 / 4$ lb., 50c.

NICHOL'S MEDIUM GREEN-Of medium length, smooth and straight, dark green. Grown largely for supplying pickle factories. Price: Pkt., 5e oz., 10c; $1 / 4$ lb., 25c.

JERSEY PICKLE-Quite pointed at both ends. Intermediate between the long and short green. Makes hard, brittle pickle. Very early. Price: Pkt., 5c; oz.; 10c; $1 / 4$ lb., 25c.

TAILBY'S HYBRID-A famous southern variety. Very productive and of a delicious flavor. An elegant long market sort. Price: Pkt., 5c; $1 / 2 \mathrm{oz}$. 10c; oz., 15e; $1 / 4$ lb., 35e.

EARLY GREEN CLUSTER-Short and prickly. A favorite for bottle pickles on account of its great productiveness. Don't fail to try these. Price: P'kt., 5c; oz., 10c; 1/4 1b., 25c.

DILL-For flavoring pickles and as a condiment Price: Pkt., 5c; oz., 10c; lb., 75c.

\#HOARHOUND-For cough remedies. Price: Pkt., 5c; $1 / 2$ oz., 10c; oz., 20c.

*LAVENDER-Leaves for seasoning, dried flowers for perfuming. Price: Pkt., 5e; $1 / 2$ oz., 15e oz., 25c.

MARJORAM, SWEET-Used like sage and thyme in seasoning. Price: Pkt., 5c; $1 / 2$ oz., 10c; oz., 15c; 1b., \$1.25.

*ROSEMARY-Hardy, aromatic, evergreen shrub. Pirice: Plkt., 5c; 1/2 oz., 15c; oz., 25c.

*SAGE, COMMON-Price: Pkt., 5c; oz., 10c; 1 1b., \$1.00.

SAFFRON-Used in medicine, also in dyeing. Price: Pkt., 5c; 1/2 oz., 10c; oz., 15c.

*SAVORY, SUMMER-Thyme-like flavor. Price: Pkt., 5c; 1/2 oz., 10c; oz., 15c; lb., \$1.50.

* SORREL, BROAD-LEAVED-F or b o 11 ing "greens" or salad. Cook like spinach, or with it one-third Sorrel. Price: Pkt., 5c; $1 / 2$ oz., 15c; oz. 25c.

*THYME, SWEET-For seasoning soups, etc. also tea for nervous people. Price: P'kt., 5c; 1/2 oz., 15c; oz., 25e; 1b., \$2.50.

TARRAGON (Estragon)-For flavoring. The voung leaves are used for pickles, vinegar, etc. Price: Pkt., 15c.

*WOODR UFF-Fragrant leaves and stems; used for putting among clothes, in Germany, to flavo: the "Maitrank." Price: Pkt., 10e; 1/2 oz., 30e; oz., 60c.

*WORMWOOD-Used medicinally and in liquors; a good tonic for poultry. Price: Pkt., 5c; 1/2 oz., 15e; oz., 25c. 


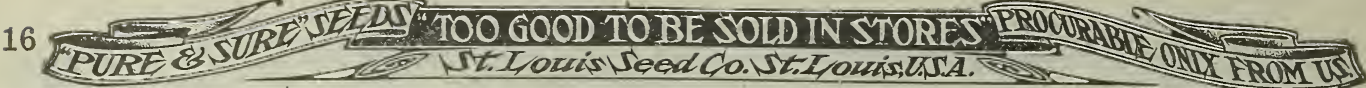
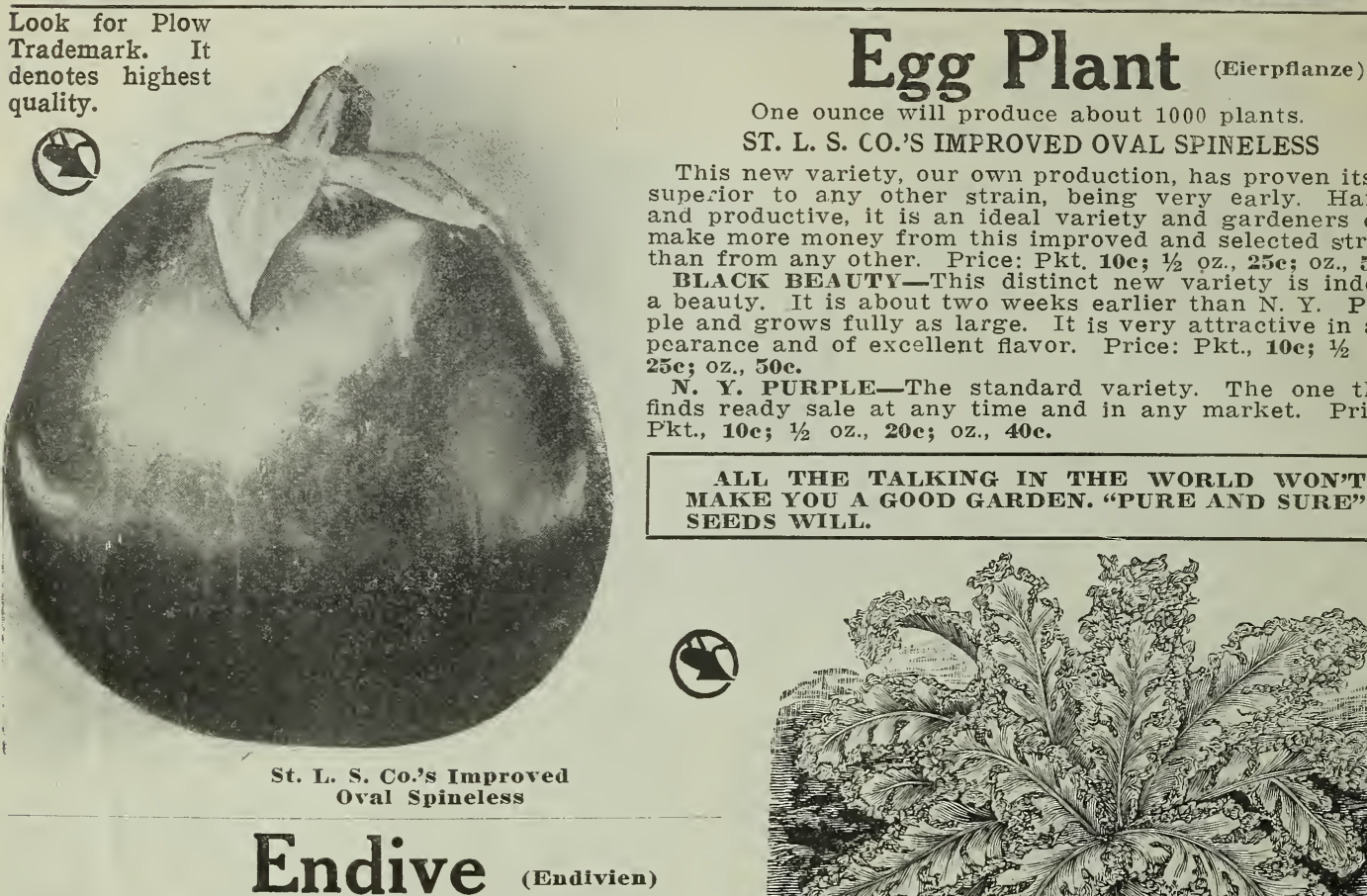

One ounce will produce about 1000 plants.

ST. L. S. CO.'S IMPROVED OVAL SPINELESS

This new variety, our own production, has proven itself superior to any other strain, being very early. Hardy and productive, it is an ideal variety and gardeners can make more money from this improved and selected strain than from any other. Price: Pkt. 10e; 1/2 oz., 25e; oz., 50e.

BLACK BEAUTY - This distinct new variety is indeed a beauty. It is about two weeks earlier than N. Y. Purple and grows fully as large. It is very attractive in appearance and of excellent flavor. Price: Pkt., 10e; $1 / 2$ oz., 25e; oz., 50c.

N. Y. PURPLE-The standard variety. The one that finds ready sale at any time and in any market. Price: P'kt., 10e; $1 / 2$ oz., 20c; oz., 40e.

ALL THE TALKING IN THE WORLD WON'T MAKE YOU A GOOD GARDEN. "PURE AND SURE" SEEDS WILL.

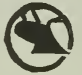

One ounce will sow 150 feet of drill.

A fall and winter salad of remarkable merit. Very easily grown and a money maker for gardeners and truckers. Sow seed as late as July in shallow drills about 15 inches apart. After plants are started thin out to 12 inches apart.

GREEN CURLED-Ornamental curled leaves of dark green color. Blanches white and crisp. Price: Pkt., 5e; $1 / 2$ oz., 15e; $1 / 4$ lb., 50c.

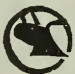

WHITE CURLED-Leaves not so tender as the green, but is self blanching and very attractive. Price. Pkt., 5c; $1 / 2$ oz., 19c; oz., 15c: $1 / 4$ 1b., 50c.

BROAD-LEAFED GREEN-Large heads and thick leaves. Price: Pkt., 5e $1 / 2$ oz., 10e; oz., 15e; $1 / 4$ 1b., 50e.
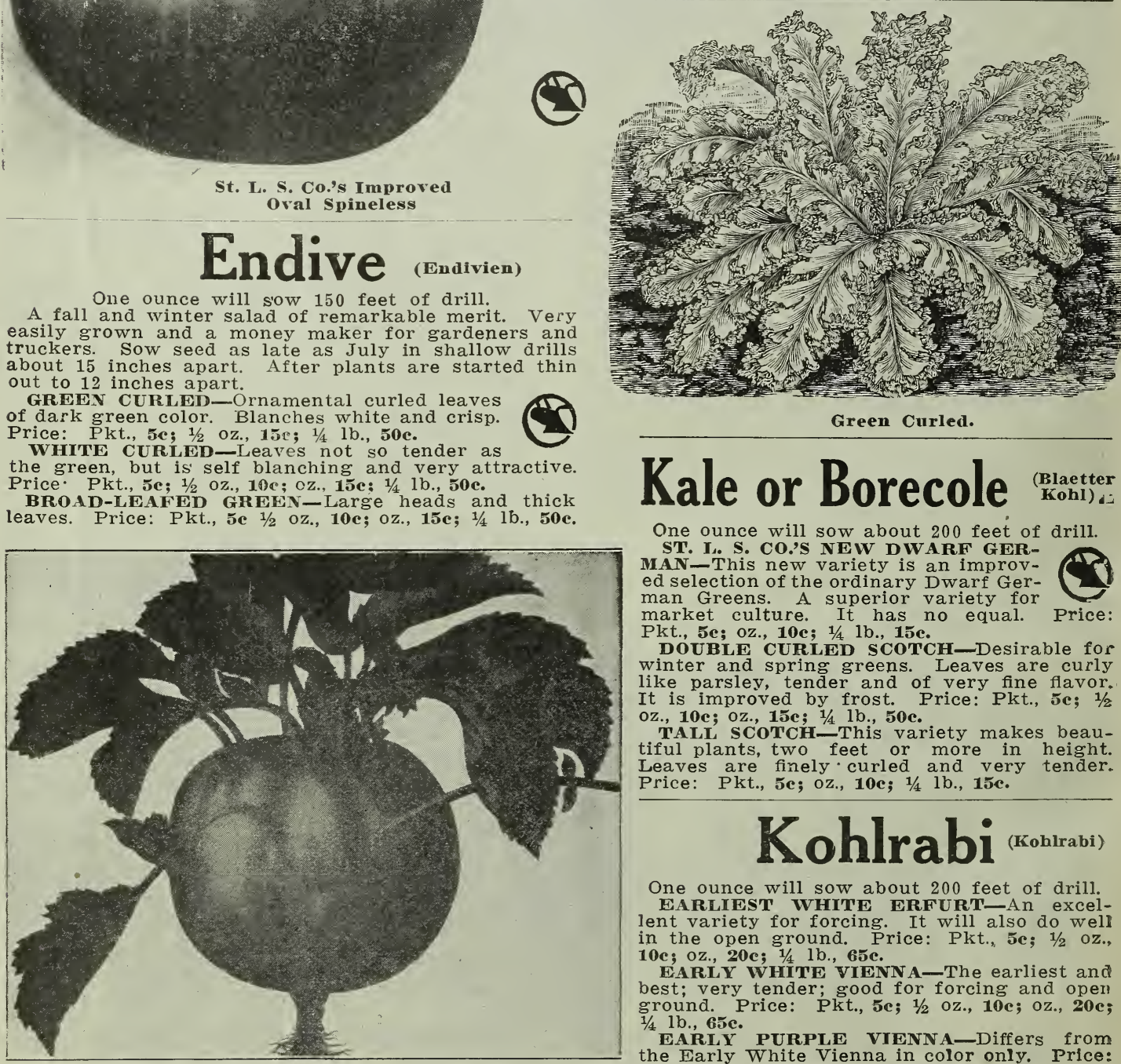

Green Curled.

\section{Kale or Borecole sockster}

One ounce will sow about 200 feet of drill.

ST. I. S. CO.'S NEW DWARF GERMAN-This new variety is an improved selection of the ordinary Dwarf German Greens. A superior variety for market culture. It has no equal. Price: Pkt., 5e; oz., 10c; $1 / 4$ 1b., 15e.

DOUBLE CURLED SCOTCH-Desirable for winter and spring greens. Leaves are curly like parsley, tender and of very fine flavor. It is improved by frost. Price: Pkt., 5e; $1 / 2$ oz., 10e; Oz., 15e; $1 / 4$ lb., 50e.

TALL SCOTCH-This variety makes beautiful plants, two feet or more in height. Leaves are finely curled and very tender. Price: Pkt., 5c; oz., 10c; 1/4 1b., 15e.

\section{Kohlrabi (Kohrabi)}

One ounce will sow about 200 feet of drill.

EARLIEST WHITE ERFURT-An excellent variety for forcing. It will also do well in the open ground. Price: Pkt., 5e; $1 / 2$ oz., 10c; oz., 20c; $1 / 4$ lb., 65e.

EARLY WHITE VIENNA-The earliest and best; very tender; good for forcing and open ground. Price: Pkt., 5e; $1 / 2$ oz., 10e; oz., 20e $1 / 4$ 1b., 65e.

EARIY PURPLE VIENNA-Differs from the Early White Vienna in color only. Price: [Early White Vienna 


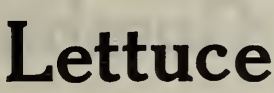

(Lattich Salat)

One ounce will produce about 4000 plants. ST. L. S. CO.'S BLACK SEEDED FORCINGThe favorite of gardeners who grow for the St. Louis market. Heads grow of medium size, well formed and compact. Of excellent quality and fine appearance. Early, tender and delicious. Pirice: Pkt., 5c; $1 / 2$ oz., 10e; oz., 15e; $1 / 4$ 1b., 50c.

GRAND RAPIDS-Especially adapted for early family use. A loose-headed Lettuce of pleasing appearance and remarkable table merit. A quick grower and a good shipper. Seed black. Price: Pkt., 5c; $1 / 2$ oz., 10c; oz., 15c; $1 / 4$ 1b., 35c.

BIG BOSTON-An excellent forcing variety. Fine to grow in frames during winter, and it also succeeds outdoors in the cool spring and fall months. Heads very large, solid, beautifully blanched and of superior quality. Price: Pkt., 5e; $1 / 2$ oz., 10c; oz., 15e; $1 / 4$ 1b., 50c.

HANSON-In every respect an ideal Lettuce. It never fails to make large, handsome heads. Price: Pkt., 5c; $1 / 2$ oz., 10c; oz., 15c; $1 / 4$ lb., 35c.

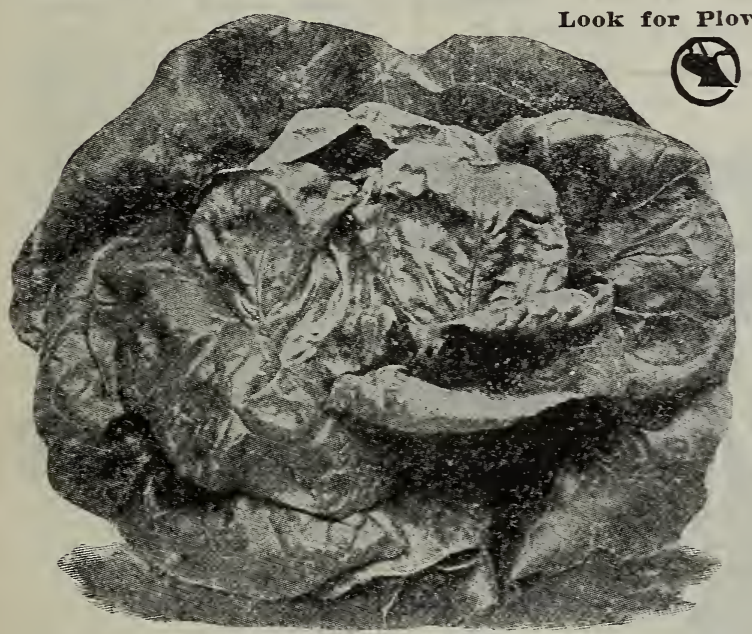

HARDY GREEN WINTER - VerY popular. Price: Pkt., 5c; 1/2 oz., 10c; oz., 15c: 1/4 1b., 35c.

BROWN DUTCH WVIN'TER-The standard winter sort. Of delicious flavor. Price: Pkt., 5c; $1 / 2$ oz., 10c; oz. 15e: $1 / 4$ lb., 35c.

TRIANON COS (ROmaine) -A distinct variety, tall, self bleaching. Price: Pkt., 5c; $1 / 2$ oz., 10c; oz., 15c; $1 / 4$ 1b., 50c.

\section{St. Louis Market}

A favorite with gardeners; its good qualities always insure for it a big market demand. As a head Lettuce it is

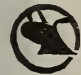
not excelled by any. Gardeners use it both for winter forcing and late summer planting; in fact they make an all-year-round variety of it. Large, hard heads of crisp, buttery flavor. A fine summer variety for home garden. Price: Pkt., 5e; 1/2 oz., 10c; oz., 15e; $1 / 4$ ib., 50c.

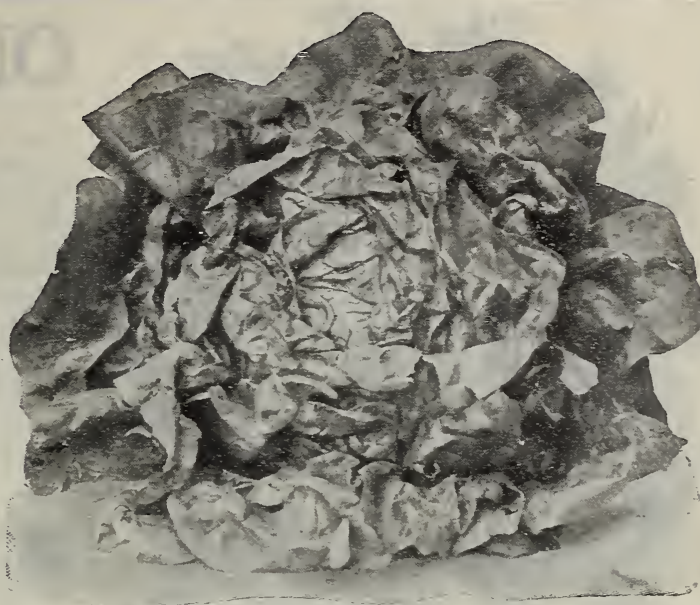

St. Louis Black Seed Forcing

EARLY CURLED SIMPSON-The standard cutting or loose-headed variety. Earlier than the heading sorts. Forms a large, loose, compact mass of curled leaves of yellowish green color. Price: Pkt., 5c; $1 / 2$ oz., 10c; oz., 15c; 1/4 lb., 35c.

BLACK SEEDED SIMPSON-Larger and lighter in color than Early Curled Simpson. This is the most popular and best selling market variety. Price: Pkt., 5c; $1 / 2$ oz., 10c; 0z., 15c; $1 / 41 \mathrm{~b}$., 35c.

JERSEY CREAM LETTUCE-This is one of the finest, the mos't brittle as well as the crispest Lettuce. This delicious variety is of the cabbage type; the heads are solid and of great size; the leaves are rich, creamy flavored, hence the name, "Jersey Cream Lettuce." Our description can but give a very faint idea of this remarkable new variety; in fact it cannot be overestimated or over-praised, whether for home or market use. Price: Pkt., 5c; oz., 15c; 1/4 lb., 50c.

MAMMOTH BLACK SEEDED BUTTER (See Cut) - A fine variety for outdoor planting or for cold frames, either for market or home use. It produces extra large heads, very compact, of a fine flavor. Price: Pkt., 5c; $1 / 2$ oz., 10c; oz., 15c; $1 / 4$ lb., 50c.

PRIZEHEAD-As its name implies, forms a very large, loose head. Slightly tinged with brown. Remarkable for its crispness and delicacy of flavor. Price: Pkt., 5c; $1 / 2$ oz., 10c; oz., 15c; $1 / 4$ lb., 35c.

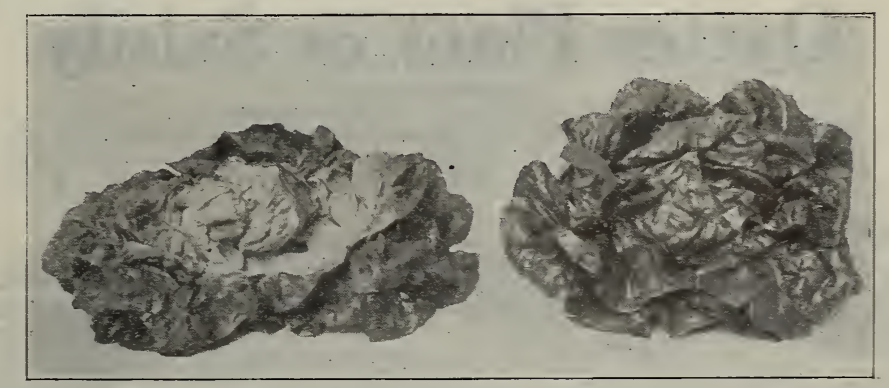

St. Louis Market 


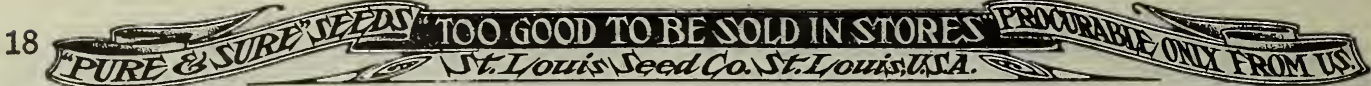

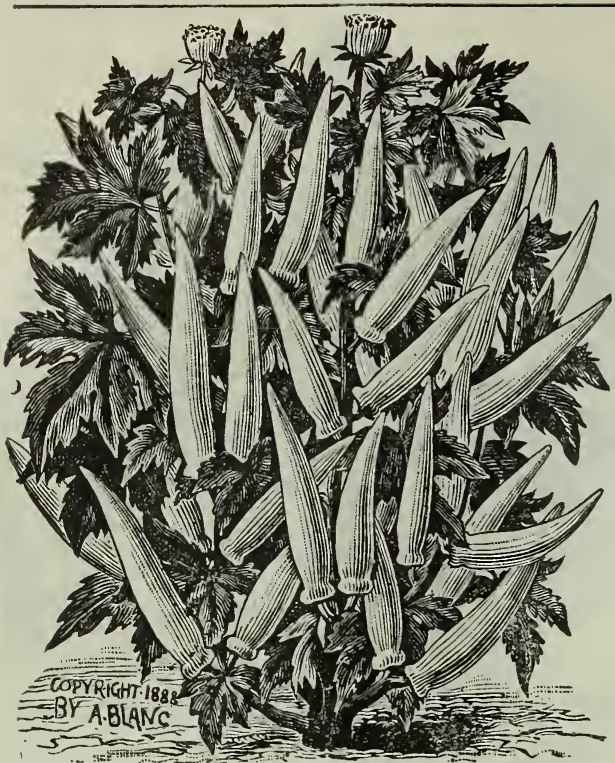

\section{Okra, or Gumbo ssastarerer \\ One ounce will sow 40 feet of drill.}

This celebrated Southern plant is becoming popular wherever grown, its nutricious young seed pods being used for stews, soups, etc., and is always in big demand. Sow seed thinly in drills one inch deep and three feet apart. When well up thin out the plants to one foot apart. Gather the pods when young. Very delicious and apetizing.

WHITE VELVET-Beautiful, smooth, velvety white pods, produced in the greatest abundance. Price: Pkt., 5e; oz., 10c; $1 / 4$ lb., 15e.

PERIKIN'S MAMMOTH LONG POD-In productiveness this Okra is simply wonderful. Pods of an intense green color, are of an unusual length and do not get hard. It is one of the best green sorts for canning for winter use. Price: Pkt.. se; z., 10c; $1 / 4$ lb., 15e.

DWARF GREEN-The standard dwarf, short green-pod variety. Very productive. Price: Pkt.,

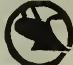
5e; oz., 10e; $1 / 4$ lb., 15e.

\section{Do you ever make a mistake? We do but we are always ready to correct it.}

\section{Leek}

One ounce will sow about

\section{0 feet of drill.}

Leek is a mild onion-flavored plant, prized as' being the ideal for soup, etc. Hotels and the elite set prize them highly when sliced and served as a salad. Sow in very rich soil, early in April, in drills, covering the seed about $1 / 2$ in. deep. After plants are strong enough looking, transplant in rows 1 foot apart and 6 inches apart in the row. Draw the earth around them as they grow in order to blanch.

LONDON FLAG-The earliest, largest and most uniform of all. Grown extensively for home or mar ket use. Price: Pkt., 5es $1 / 2$ oz., 10e; oz., 15e; $1 / 4$ lb.

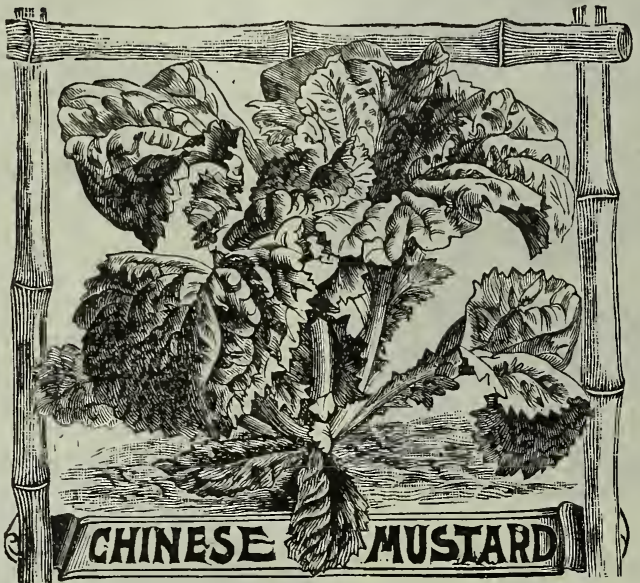

\section{Mustard}

(Senf)

One ounce will sow 40 feet of drill.

Mustard should be sown in every garden. As a money maker it attains a high rank, always being in oreat demand by hotels: for greens, salads, etc., it is unsurpassed. Sow thickly in rows and cut when two or three inches ligh.

CHINESE C U R L E DWhen cooked like spinach the broad leaves of this variety are delicious. They are often more than a foot in length, and crimped much like the Savoy Cabbage. Stands long before running to seed. Price: Pkt., 5e: oz., 10e: 1/4 1b., 15c. GIANT SOUTH ER N CURLED - A favorite in the South, growing very large with a beautiful curled leaf. It is

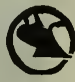
very tender and of especially good flavor; also desirable for garnishing. Price: Pkt., 5e; oz., 10e; $1 / 4$ 1b., 15.e.

WHITE OR YELLOW LONDON-Seeds are used for pickling and the leaves. are relished by many people. Price: Pkt., 5e; oz., 10c; $1 / 4$ 1b., $15 c$.

LARGE ROUEN-A large, thick, short-stemmed variety; excellent for either autumn or winter use; slow to run to seed. P'rice: Pkt., 5e; $1 / 2$ oz., 10c; oz., 15e; $1 / 4$ lb., 50c.

\section{Oyster Plant or Salsify \\ (Haferwurzel)}

One ounce will sow 50 feet of drill.

MAMMOTH SANDWICH ISLAND-The favorite variety of Salsify, as well as the largest and best sort in cultivation; very hardy. Grown extensively by garcieners and truckers everywhere. Price: Pkt., 5e; oz., 10e; $1 / 4$ ib., 30e.

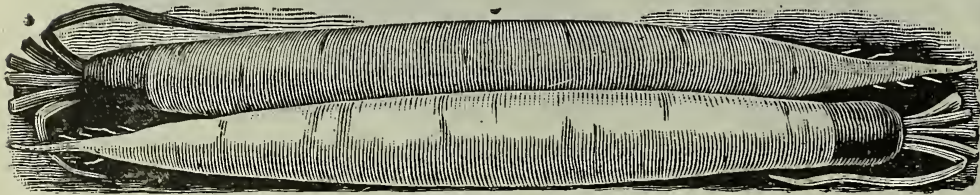

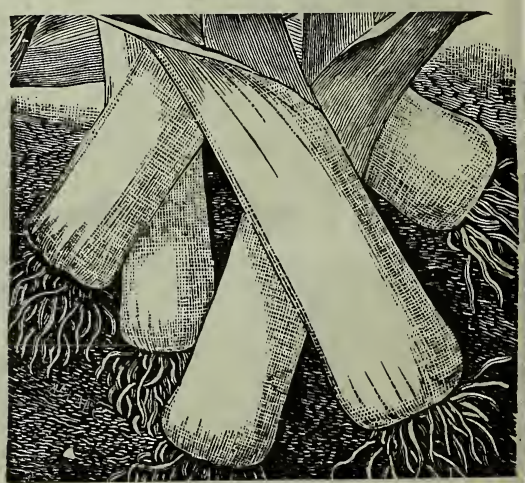

Large Rouen 


\section{Muskmelon areanen}

One ounce will plant about 60 hills. Two pounds will plant an acre.

NEW BURREL GEM-The flesh is of the most handsome salmon color, the skin of a beautiful netted dark green: it is shallow ribbed and shaped similar to the Rocky Ford, only larger; it is the greatest, the grandest and the finest Muskmelon ever discovered (with the exception of our new Monarch-of-the-West). Price: Pkt., 5e; $1 / 2$ oz. 10c; oz., 15e; 1/4: 1b., 50c.

ST. L. S. CO.'S TIP-TOP-There are other muskmelons. but none can really surpass or very few equal this excellent variety. Nearly every planter loves the Tip-Top. Every melon, whether big or little, early or late, is a good onesweet, juicy, finest flavor. Price: Pkt., 5e; $1 / 2$ oz., 10e; oz., 15e; $1 / 4$ lb., 40c.

ROCKY FORD-Shape is oblong, slightly ribbed, densely netted. P'rice: Pkt., 5c; oz., 10c; $1 / 4$ lb., 25c.

ST. LOUIS MARKET-Pronounced by many growers the "King of Muskmelons." By far the sweetest and most iuscious, richly flavored melon ever grown. Flesh is green and delicious, rind is green and solid, with a rich aromatic flavor that is simply indescribable. Price: Pkt., 5c; $1 / 2$ oz., 10c; oz., 15e; $1 / 4$ lb., 50c.

SEE PAGE 7 FOR NEW VARIETIES.
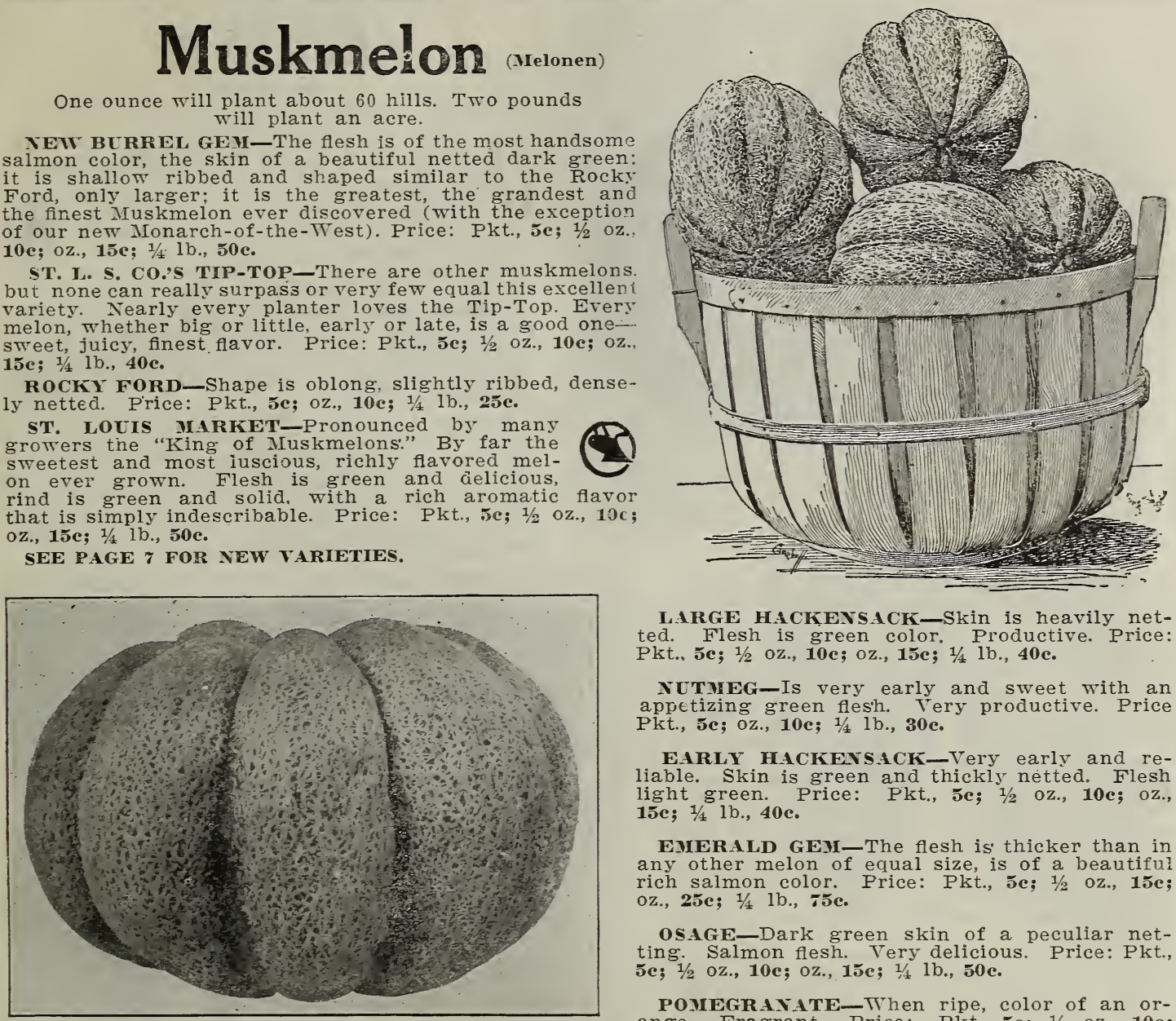

LARGE HACKENSACK-Skin is heavily netted. Flesh is green color. Productive. Price: Pkt., 5e; $1 / 2$ oz., 10e; oz., 15e; $1 / 4$ lb., 40c.

NUTMEG-Is very early and sweet with an appetizing green flesh. Tery productive. Price Pkt., 5e; Oz., 10c; 1/4 lb., 30c.

EARLY HACKEVSACK-Very early and reliable. Skin is green and thickly netted. Flesh light green. Price: Pkt., 5e; $1 / 2$ oz., 10e; oz., 15e; $1 / 4$ lb., 40c.

EMERALD GEY-The flesh is thicker than in any other melon of equal size, is of a beautifu? rich salmon color. Price: Pkt., 5ீe; $1 / 2$ oz., 15e; oz., 25e; $1 / 4$ lb., 75e.

OSAGE-Dark green skin of a peculiar netting. Salmon flesh. Very delicious. Price: Pkt., 5e; $1 / 2$ oz., 10e; Oz., 15e; $1 / 4$ lb., 50e.

POMEGRANATE- Then ripe, color of an orSt. Louis Market ange. Fragrant. Price: Pkt., 5e; $1 / 2$ oz., 10c; oz., 20c.

\section{Watermelon}

One ounce will plant about

30 hills. Four pounds

(Wassermelonen)

ST. L. S. CO.'S SWVEETHEART-This melon is our great leader; it is one of the finest large melons in existence. Almost globular, but a little longer than thick. Skin is a beautiful light, bright mottled green, thin, but very tough rind. Price: Pkt., 5e; Oz., 10e; $1 / \pm$ lb., 25e.

MeIVER'S WONDERFUL SUG.IR-This celebrated meion is claimed by many to be the stieetest of all varieties. Crisp, free from any strings. Solid meat. Price: Pkt., 5e; oz., 10e; $1 / 4$ 1b., 25e.

FLORIDA FAVORITE-Shape oblong, with light and dark green skin; flesh is bright crimson and deliciously sweet. We offer only a select stock of this famous melon. Price: Pkt., 5e; oz., 10e; 1/1 lb., 20c.

ALABAMA sWEET-This, without question, is the greatest melon ever offered. It is superior to others both in size and weight. Price: Pkt., 5e; oz., 10e; $1 / 4$ lb., 25e.

HAIBERT HONEX-Fully equals the Kleckley Sweets in superb luscious flavor, and has fruits more even and regular in outline, with a darker, richer colored skin. The vines are of strong, vigorous growth and set fruits very freely. Price: Pkt., 5e; oz., 10e; $1 / 4$ lb., 25e.

FORDHOOK EARLT-The earliest large variety. Excellent quality. Best for home use. Price: Pkt., 5e; oz., 10e; $1 / 4$ lb., 20e.

IMPROVED TRIUMPH-The largest, the sweetest and one of the most beautiful melons in cultivation. Nedium late. Price: Pkt., 5r; oz., 10e; 1/1 1b., 25e.

KLECKLEY SWEETS (Monte Cristo)-Is especially recommended for its fine flavor-in this respect surpassing most all others. Price: Pkt., 5e; oz., 10c; $1 / 4$ lb., 25e.

BLACK DIAMOND-A large melon, very productive. It is oval in shape with very dark skin; often grows to weigh 50 to 90 pounds; has fine red meat; one of the best varieties for local use. Price: Pkt., 5c; oz., 10e; $1 / 4$ lb., 25c.

CITROx-Grown extensively for preserving. Price: Pkt., 5e; oz., 10e; $1 / 4$ lb., 20e. 


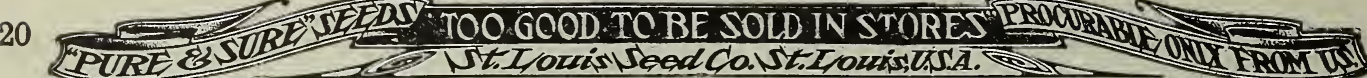

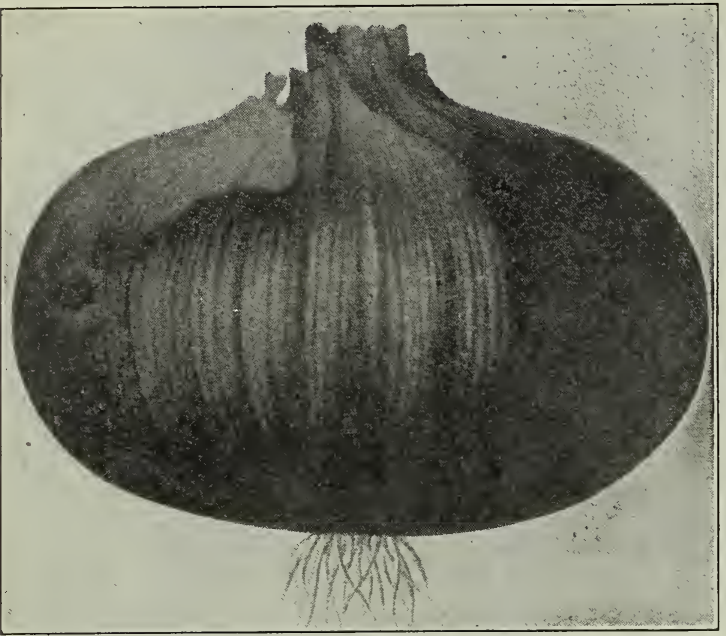

\section{Onion}

(Zwiebeln)

An ounce will sow 100 feet of drill. Four to five pounds to the acre.

St. L. S. Co.'s Large Red Wethersfield U DOUBTEDLY the most popular Oni
grown. The standard of all red varieties. Skin is deep purple red, flesh purplish white. Very fine grained and of excellent flavor. (See cut.) Price: Pkt., 5e; $1 / 2$ Oz., 10c; 0z., 15e; $1 / 41 \mathrm{~b} ., 45 c$.

LARGE RED GLOBE-This celebrated variety differs from the Wethersfield in being almost a perfect globe, and matures later, and by its handsome appearance on the market sells better. An excellent keeper. Price: Pkt., 5c; $1 / 40 z ., 10 c ;$ oz., 15e; $1 / 4$ lb., 45e.

GIANT YELLOW PRIZE TAKER-Our new Giant Yellow Prize Taker cannot be recommended too highly. There is a limit to the good qualities of other Onions. There is no limit to this wonder of the Onion world. The king of all main crop varieties. Color is of a beautiful straw hue with pure white flesh. Price: Pkt.,

Large Red Wethersfield 5e; $1 / 20 z ., 10 c ; 0 z ., 15 e ; 1 / 41 b ., 50 c$.

LARGE WHITE GLOBE-This celebrated Onion in appearance and quality is one of the finest in cultivation. Perfectly globeshaped, with pure white skin; fine grained and of excellent flavor. A good keeper. Like all globe-shaped varieties, it is later in ripening than flat sorts, but brings a higher price on the market. The market demand most always being greater than the supply. Price: Pkt., 5c; $1 / 2$ oz., 10c; oz., 20c; $1 / 4$ lb., 60c.

MAMMOTH SILVER KING (White Garganus)-One of the greatest, grandest and most delicious Onions ever offered. Grows very large, early; flat, but thick through; tender and of very mild sweet flavor: uniform in size and shape. We recommend it for exhibition at fairs and for the fancy market as well as the home table. You cannot lose when you plant this Onion. Price: P'kt., 5e; $1 / 2$ oz., 10e; oz., 15e; $1 / 4$ lb., 50c.

PHILADELPHIA SILVERSKIN-A Favorite eastern variety. Makes the best white sets. Price: Pkt., 5e; 1/20z., 10c; oz., 15c; $1 / 4$ lb., 45e.

WHITE BERMUDA-It is one of the earliest in maturing, is of a straw color with pure white flesh. Very profitable for market early. Price: Pkt., 5e; $1 / 2 \mathrm{oz}$., 15e; oz., 25e; $1 / 41$ b., 75e.

EARLY RED TRIPOLI-A grand early red

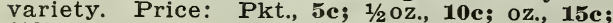
$1 / 41 b ., 45 c$.

\section{Onion Sets}

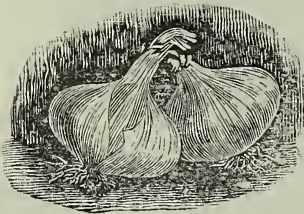

Prices Subject to Change.

(32 Pounds to the Bushel)

POTATO ONIONS-The small bulbs increase in size and the parent bulb produces a quantity of bulbs in a cluster. Mild, sweet flavor. The earliest to make a large ripe bulb. The large bulbs produce the small, and the small the large, alternately. For best results plant potato sets in fall. Price: Small, qt. 15e; gal., 50c; pk., 85e; bu., \$2.50. Large, qt., 10c; gal.,35e; pk., 65e; bu., \$2.00.

Qt. Gal. Pk.

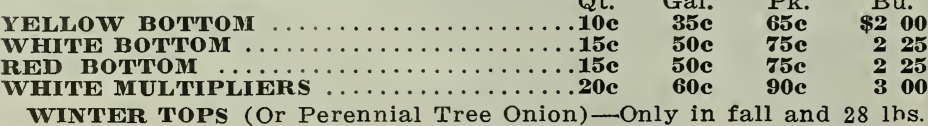
per bushel.

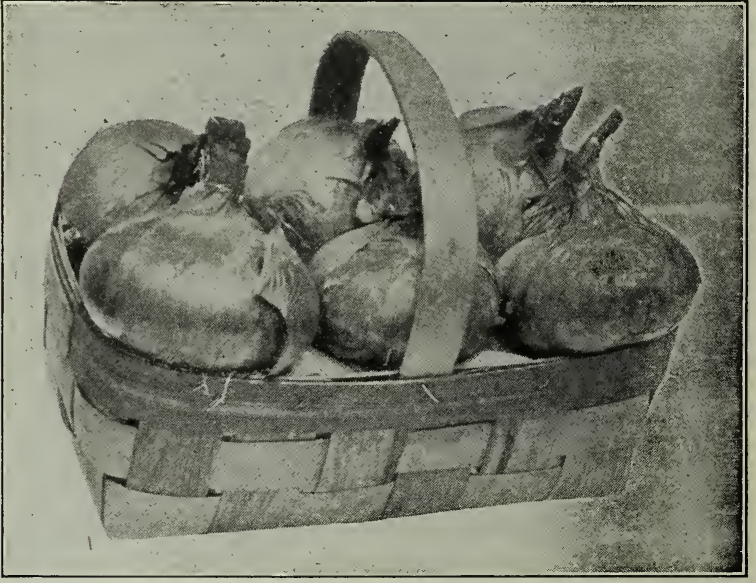

St, L, S, Co,'s Giant Yellow Prize Taker

\section{GARIC}

TSED for flavoring soups, stews and other dishes. The crop matures in August, when it is harvested like the onion crop. Price: 20c per 1b., or 10 lbs. $\$ 1.50$.

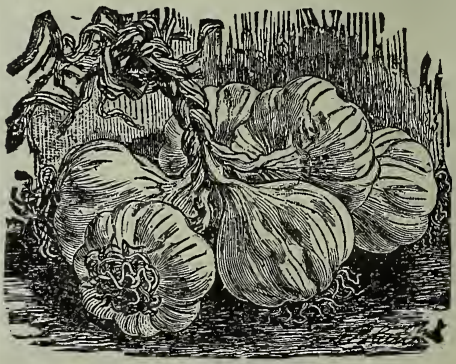

Garlic Roots. 


\section{PEAS (rrterea)}

One quart will plant 100 feet of drill. One to one and a quarter bushels per acre.

\section{Extra Early Varieties}

ST, L. S. CO'S IMPROVED EXTRA EARLY - The King of all extra earlies. Superior to all rivals. Very prolific, bushes becoming loaded with large, smooth green peas of beautiful texture. Matures in from 40 to 45 days after germination, very uniformly. Price: Pkt., 5e; $1 / 2$ pt., 10c; pt., 20c; qt., 30c.

ALASKA-One of the earliest smooth varieties. Pods are a dark green color, extra well filled and ripen very uniformly. Height about 2 feet. Price: Pkt., 5c; $1 / 2$ pt., 10c; pt., 20c; qt., 30c.

ST L. S. CO.'S FIRST OF ALL, OR ECLIPSE-This is the wonderful new improved Pea that we offered last season, and which met with such hearty approval from growers everywhere. Pods grow large and solid and contain from one to two more peas to a pod than any other variety. Vines average a height of about 24 to 26 inches, and produce pods in abundance. Price: Pkt., 5c; 1/2pt., 15c; pt., 25c; qt., 35c.

GRADUS, OR PROSPERITY-Undoubtedly the best extra early Sugar Pea ever discovered. The pods grow extra large and contain from eight to twelve sweet luscious peas. Grown extensively by market gardeners for early trade. Height about 18 inches. Price: Pkt., 10c; 1/2 pt., 20c; pt., 85c; qt., 60c.

NICHOL'S DELIGHT-See Novelty page 7.

FRENCH MARKET-See Novelty page 7 .

\section{Second Early and Main Varieties}

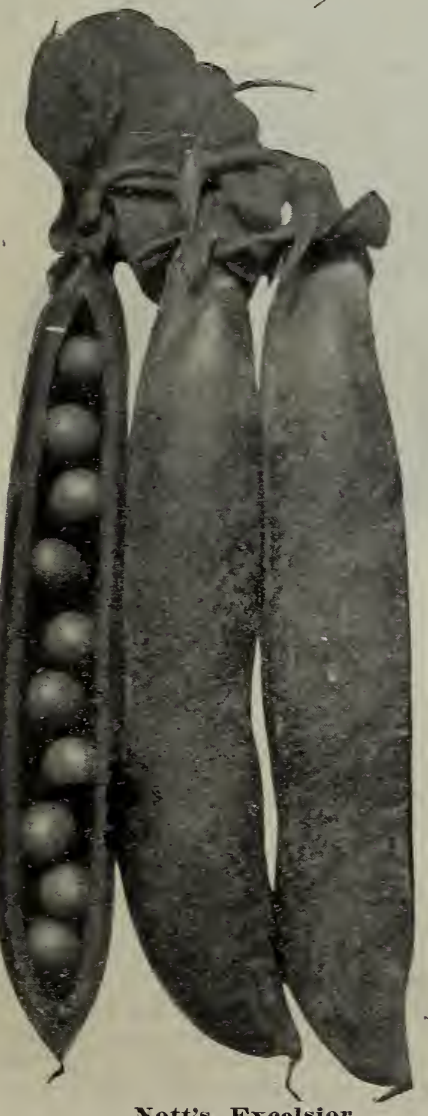

ST. L. S. CO.'S NOTT'S EXCELSIOR - Our new strain of this celebrated standard variety is indeed a winner. Everyvariety. In brief, this new strain combines all the good qualities of the dwarf varieties. Price: Pkt., 5c; $1 / 2$ pt., 15c; pt., 25c; qt., 40c.

AMERICAN WONDER - An early dwarf Pea that is a wonful bearer. Its bushes, growing only about one foot high, are literally covered with pods of dark green texture. A good home sort. Price: Pkt., 5c; 1/2pt., 15c; pt., 25c; qt., 40c.

ST. L. S. CO.'S SECOND EARLY - This Pea is one of the finest second early peas on earth, with the exception of Nichol's New Winner. We say this, weighing each word, and repeat it. Ripens about two weeks later than our Extra Early variety. Height about two feet. Price: Pkt., 5e; 1/2pt., 15e; pt., 25c; qt., 40 e.

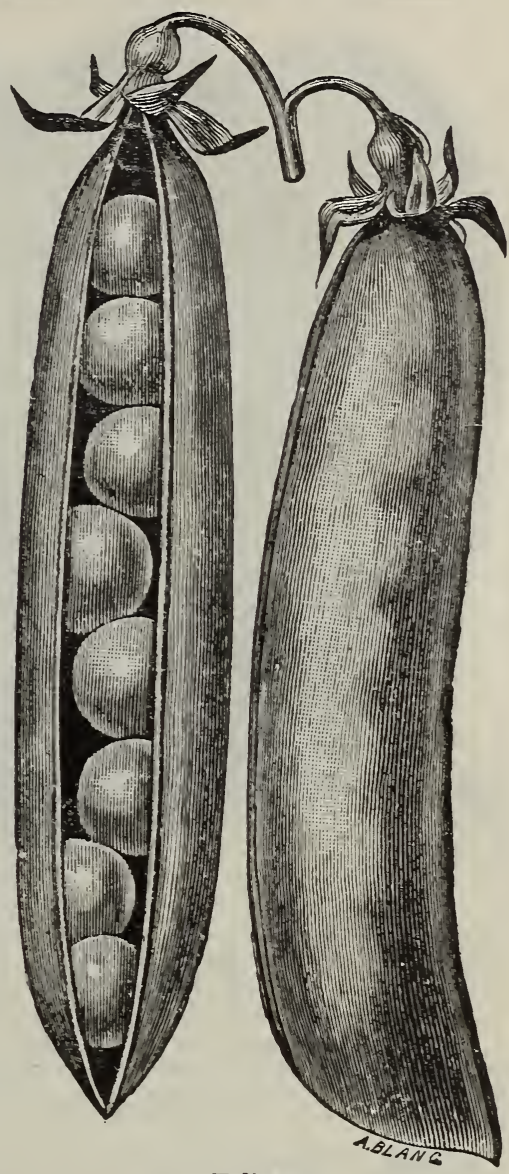

Eclipse

\section{It Pays to Buy the Best}

NICHOL'S NEW WINNER-The greatest, the grandest and most productive second early Pea ever discovered. So far we have been unable to supply the demand for this famous Pea. Bushes grow to a height of 24 to 26 inches and are laden down with extra long, rich colored pods. Owing to its immense size, it requires only about two-thirds as many pods to fill a bushel basket as other sorts. Price: Pkt., 5c; 1/2pt., 20c; pt., 30c; qt., 50c.

CHAMPION OF ENGLAND-The leading late Pea of the South, as well as one of the richest and best flavored peas grown. Grows to a height of five feet bearing large-sized pods. Price: Pkt., 5c; $1 / 2$ pt., 10c; pt., 20c; qt., 35c.

BLACK-EYED MARROUVFAT-An old-time favorite Height five feet. Price: Pkt., כe; 1/2pt., 10c; pt., 15c; qt., 25c.

WHITE MARROWVAT-Like the Black-Eyed Marrowfat, this variety is extensively sown as a field crop. Price: Pkt., 5c; $1 / 2$ pt., 10c; pt., 15c; qt. 25c.

EDIBLE POD, TALL MELTING SUGAR-A foreign pea little known in this country. A wonderfully productive sort. Price: Pkt., 5c; $1 / 2$ pt., 15c; pt., 25e; qt., 40c.

DWVARF GREY SUGAR-Of a dwarf growth, a fine edible pod when young. Price: Pkt., 5c; $1 / 2$ pt., 15e; pt., 25e; qt., 40c. 

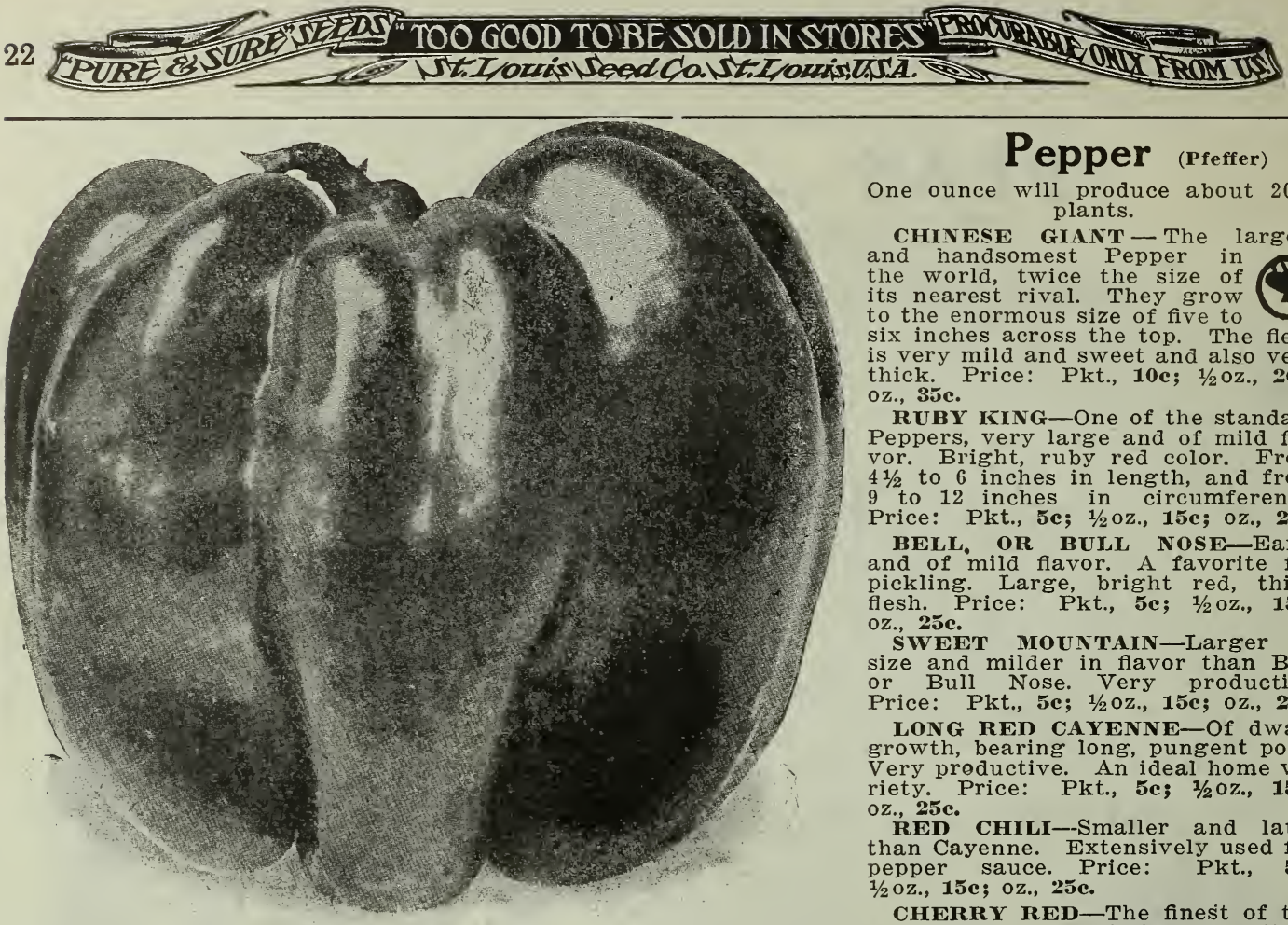

Pepper (Pfeffer)

One ounce will produce about 2000 plants.

CHINESE GIANT - The largest and handsomest Pepper in the world, twice the size of its nearest rival. They grow to the enormous size of five to six inches across the top. The flesh is very mild and sweet and also very thick. Price: Pkt., 10c; 1/20z., 20c; oz., 35c.

RUBY IKING-One of the standard Peppers, very large and of mild flavor. Bright, ruby red color. From $4 \frac{1}{2}$ to 6 inches in length, and from 9 to 12 inches in circumference. Price: Pkt., 5c; $1 / 20 z ., 15 c ; 0 z ., 25 c$.

BELL, OR BULL NOSE-Early and of mild flavor. A favorite for pickling. Large, bright red, thick flesh. Price: Pkt., 5e; 1/20z., 15e; oz., 25c.

SWWEET MOUNTAIN-Larger in size and milder in flavor than Bell or Bull Nose. Very productive Price: Pkt., 5c; 1/20z., 15c; oz., 25e.

LONG RED CAYENNE-Of dwarf growth, bearing long, pungent pods. Very productive. An ideal home variety. Price: Pkt., 5e; 1/20z., 15e; oz., 25c.

RED CHILI-Smaller and later than Cayenne. Extensively used for pepper sauce. Price: Pkt., 5c: $1 / 2$ oz., 15c; oz., 25c.

CHERRY RED-The finest of the small round varieties. Excellent for pickles, sauce, etc. Price: Pkt., Chinesc Giant Pepper.

\section{Pumpkin (Kuerbisz)}

One ounce will plant 20 hills.

GENUINE MAMMOTH-A beautiful salmon-colored variety. A splendid keeper and valuable for stock feeding; also prized highly by growers everywhere for exhibition purposes. Price: Pkt. 5c; oz., 10e; $1 / 4 \mathrm{lb}$., 25c.

LARGE CHEESE-Shape flat; skin mottled light green and yellow, changing to a rich cream color. Price: Pkt., Je; oz., 10c; 1/4lb., 15e.

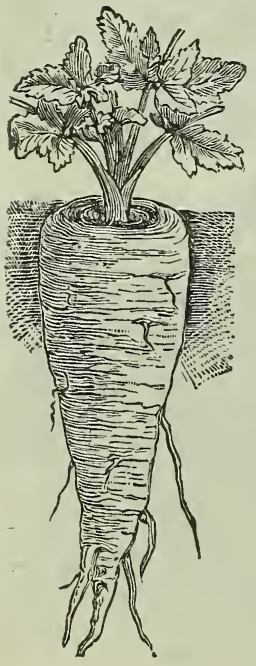

KENTUCKY FIELD-A large, round, slightly ribbed, soft shell, salmon-colored Pumpkin, that is very productive and excellent for stock. This variety is a standard sort everywhere, and is also often grown for exhibition purposes. Stock greatly relish this variety.

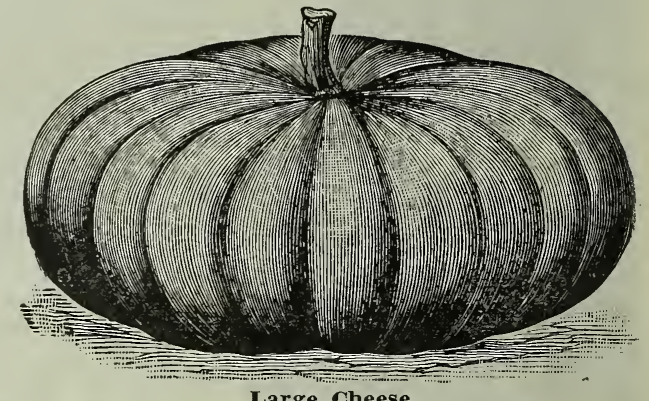

Large Cheese

LARGE YELLOW FIELD-A good stock variety, planted chiefly among corn. Price: Pkt., 5e; oz., 10c: 1/4 lb., 15e.

\section{Parsley (Petersilie)}

One ounce will sow 150 feet of drill

EXTRA CURLED-The leaves are large, beautifully curled, and of a very dark green. Price: Pkt., 5e; oz., 10c; $1 / 41 b ., 20 c$.

PLAIN-Leaves are plain or single, and are very dark colored. Price: Pkt., 5c: oz., 10c; $1 / 4$ lb., 20c.

HAMBURG (or Rooted Parsley)-Used for flavoring soups, etc. Price: Pkt., 5c; oz., 10e; $1 / 4$ lb., 20c.

\section{Parsnip (Pastinake)}

One ounce will sow 100 feet of drill. Five to six pounds to the acre.

HOLLOW CROWvN (Large Sugar)-The best and most widely cultivated variety. Grows long, smooth, tender and is very sugary. Price: Pkt., 5c; oz., 10c; 1/4 1b., 20c.

LONG WHITE-A smooth and very tender variety, well flavored. Also called Arlington Long Smooth. Price. Pkt., 5c; oz., 10c; 1/4 lb., 20c. 


\section{RADISH (Raates mad nettis)}

One ounce will sow 100 feet of drill.

EARLY SCARLET TURNIP-The famous small round red. Crisp, tender, solid and brittle. Price: Pkt., 5c; oz., 10c; 10c; $1 / 41 b ., 15 c$.

NEW EARLY SCARLET TURYIP WHITE TIP-This excellent variety differs from the regular Early Scarlet Turnip W. T. Radish only in being more beautifully tipped with white. Very attractive. Price: Pkt., 5e; oz. 10e; $1 / 4$ Ib., 15e.

ST. L. S. CO.'S NEW CRIMSON GIANT-The quickest growing small round Radish in existence; ready for the table 18 days from sowing. Price: Pkt., 5c; oz., 10c; $1 / 41 \mathrm{~b}$. , 20c.

PHILADELPHIA WHITE BOX-This famous white turnipshaped or globe-shaped Radish is the foremost of its class. Price: Pkt., 5e; oz., 10e; 1/41b., 15e.

EARLY SCARLET GLOBE-It is entirely distinct and one of the earliest. In flavor it is mild, crisp to juicy and tender. It forms a small top and will stand a great amount of heat without becoming pithy. Price: Pkt., 5e; oz., 10e; $1 / 41$ b., 15c.

FRENCH BREAKFAST-Too well known to need any introduction. Scarlet with white tips. Price: Pkt., 5c; oz., 10c; $1 / 41 \mathrm{~b} ., 15 \mathrm{c}$.

YELLOW SUMMER TURNIP-Stands the heat well; can be sown late. A general favorite with market gardeners; globe shaped. Price: Pkt., 5c; oz., 10c; 1/41b., 15c.

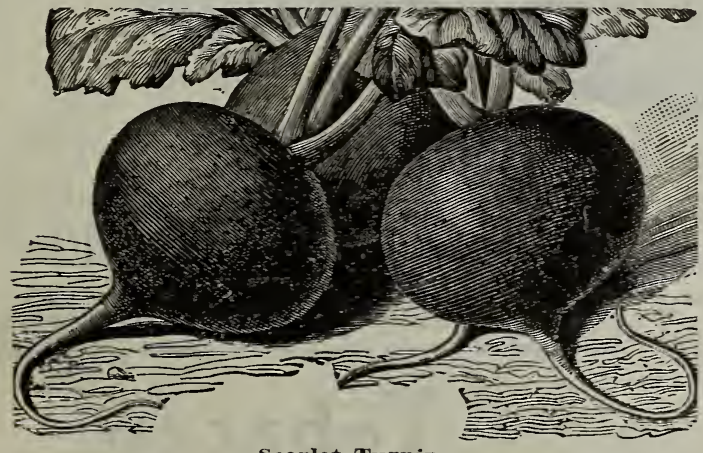

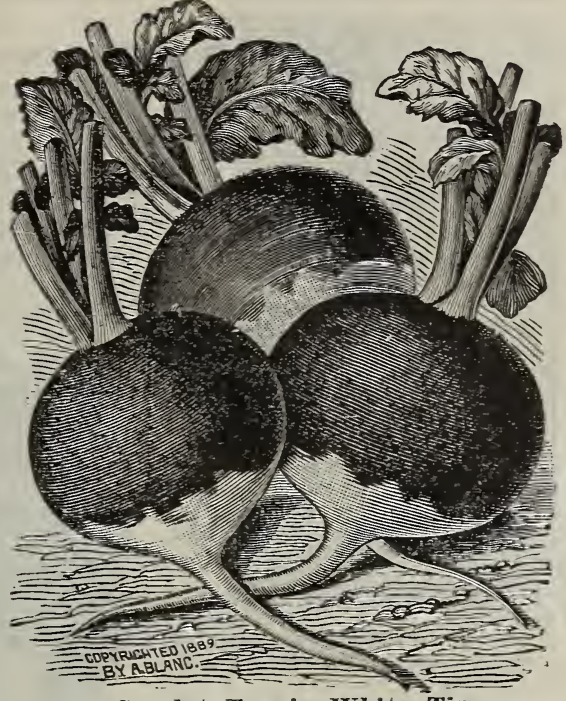

Scarlet Turnip White Tip.

ST. LOUIS WHITE SUMMER-It is not only the favorite white summer Radish in St. Louis and vicinity, but it is popular on the market everywhere. Skin and flec pure clear white, tender Pkt., Je; oz., 10c; 1/4lb., 15c.

WHITE STRASSBURG - O b l o $\mathrm{n} g$ shaped tapering gracefully to a point. Of large size, good quality and resists heat remarkably well. Very tender, and pungent taste. Price: Pkt., 5e; oz., 10e; 1/41b., 15e. New

FIRE BALL

See Novelty page 7

NEW WHITE PEARL FORCING RADISH-(The New White Radish without a peer; without a rival) -Every one says they never saw its equal. It is of the famous half-stump rooted class, and a pearly white, appetizing color, being very crisp and brittle. Price: Pkt., 5c; oz., 10c; $1 / 4$ lb., 25c.

CINCINNATI MARKET-This is an excellent Radish of the long variety, being of a beautiful brilliant scarlet color. It has an unusually small top. Price: Pkt., 5e; oz. 10c; $1 / 41 b ., 15 c$.

ICICLE-Extra early, smooth, long, white. Derives its name from the transparent whiteness of its roots. Price: Pkt., 5c; oz., 10c; 1/4 1b., 15c.

WHITE LADY FINGER-(Long Vienna)-Of slender, graceful form and remarkably crisp, brittle and tender. Price: Pkt., 5e; oz., 10c; 1/4lb., 15c.

YELLOW OVAL SHAPED-A fine summer turnip-shaped variety; yellow in color, but white meat and tender. Price: Pkt., 5c; oz., 10c; 1/41b., 25c.

\section{Fall and Winter Varieties}

ROUND BLACK SPANISH-Grows to a large size; very solid. Price: Pkt., 5e; oz., 10c; $1 / 41 \mathrm{~b}$. , 15c.

LONG BLACK SPANISH-One of the best for winter use. Price: Pkt., 5c; oz., 10c; $1 / 41 b ., 15 c$

ROSE COLORED CHINA-Form conical; large size; firm and tender; of fine flavor. Price: Pkt., 5c; oz., 10c; $1 / 4$ lb., 15c.

WHITE SPANISH-Very solid and tender. The best white Radish for late fall planting; largely used by our market gardeners. Price: Pkt., 5c; oz., 10c; 1/41b., 20c.

\section{Our Business Grows Because Our Seeds Grow}




\section{Spinach (spinat)}

One ounce will sow 50 feet of drill. Twelve to sixteen pounds will sow an acre.

BLOOMSDALE OR SAVOY-The most popular variety with market gardeners. The leaves are wrinkled in the same manner as the Savoy Cabbage. A crop of this variety weighs much heavier than any other sort. It grows very quickly. Fine for fall sowing.

Price: Pkt., 5e; oz., 10e; 1/4lb., 15c.

LONG STANDING-The best for spring sowing. Stands a long time

before shooting to seed.

Large, thick leaves, excel-

lent for greens. Price:

Pkt., 5e; oz., 10e; $1 / 4$ lb., 15e.

NEW ZEALAND-Makes a luxuriant growth all summer. In appearance entirely

distinct from other Spinach. Its quality is very desirable and tender. Soak the seed in warm water before planting. Price: Pkt., 5e; oz., 10e; $1 / 41$ b. 30c.

ROUND THICK LEAFLeaves large and fleshy. An excellent market sort. Good for either spring or fall sowing. Grown extensively everywhere. Price: Pkt., 5e; oz., 10e; $1 / 4$ lb., 15e. PRICKLY-One of the standard varieties. leaves. Excellent for fall sowing. Price: Pkt., 5e; oz., 10e; $1 / 41$ b., 15e.

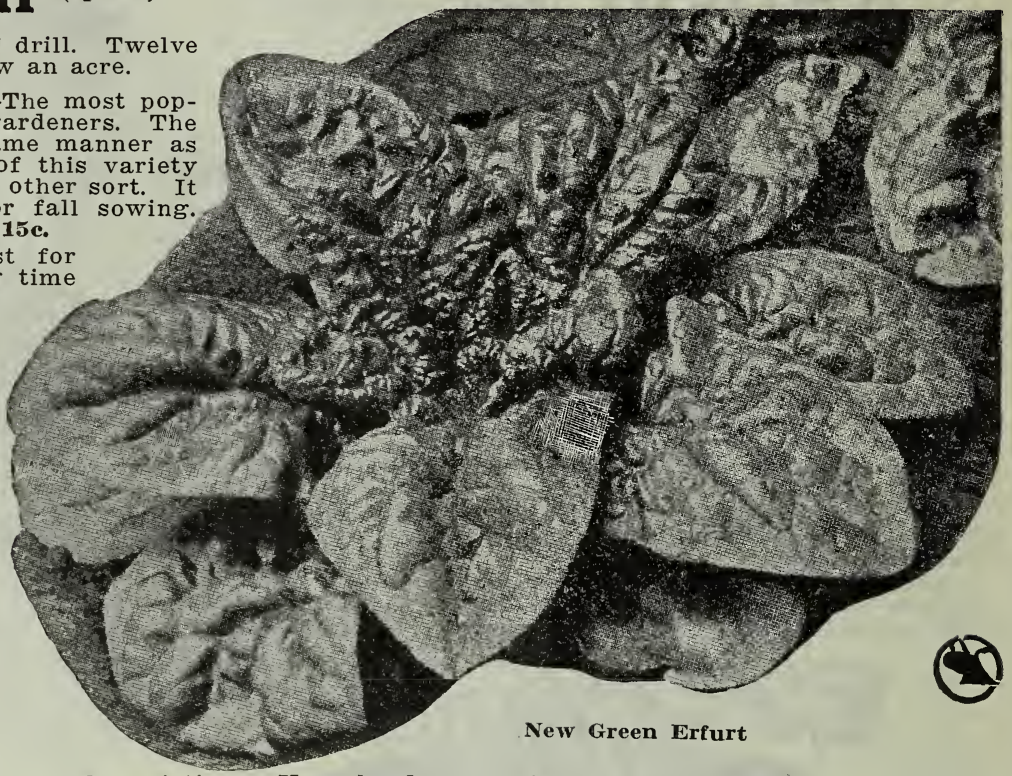

\section{Our Early Dix Potato}

will prove itself a Winner if you try it. See Page 76 for illustration and description.

\section{New Flower Novelties}

will be found on Pages 41 to 43.

Use our Famous Fertilizers, listed on Page 72 .

\section{Rhubarb}

(Rharbarber)

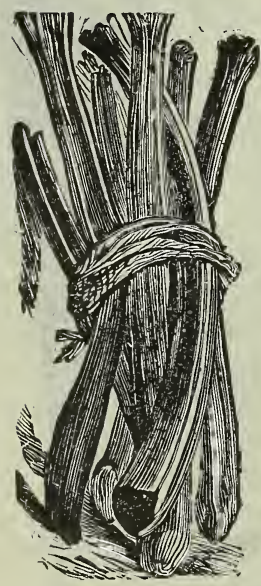

(Note-Rhubarb grown from seed should not be cut until the second year.)

EARLY LINNAEUS - The earliest and tenderest variety, fine for sauce, pies, etc. Grown largely by gardeners for early market. Price: Pkt., 5c; $1 / 2$ oz., 10e; oz., 15e; $1 / 4$ lb., 30c.

MYATT'S VICTORIA-Later than Linnaeus, but mammoth in size; also of a finer quality. Very juicy, tender and almost stringless. Price: Pkt., 5e; $1 / 2$ oz., 10c; oz., 15e; $1 / 4$ lb., 30c.

RHUBARB ROOTS-Strong roots. One year old. Price, each 10e; $1 / 4$ doz., 25e; doz., 65e; 25 , \$1.00; 100 , \$3.50. Two year old. Price, each, 15e; 2 for 25c; doz., \$1.00; 25, \$1.75; 100, $\$ 5.00$.

\section{Tobacco}

DARIK PLUG WRAPPER-Big Oronoka-A favorite Virginia variety. Grows very large, broad leaves. Price: Pkt., 5e; 1/20z., 10e; oz., 20e; $1 / 41 b$. , 60e.

MISSOURI BROAD LEAF-A well-known standard sort; very large yiclder, an ideal sort for home use. Price: Pkt., 5e; $1 / 20 z$., 10c; oz., 20e; $1 / 41$ b., 50c.

PLUG FILLER-Yellow Prior-Án elegant variety, of bright yellow color. Grown exclusively for factory as well as home use. Fine for twists. Price: Pkt., 5e; $1 / 2$ oz., 10e; oz., 20e; $1 / 21$ b., 60c.

WHITE BURLEY - The standard main crop variety, which produces one of the most fashionable types for manufacturing and sutting. Price: Pkt., 5e; 1/20z., 15e; oz., 30e: $1 / 4$ lb., \$1.00.

CIGAR WRAPPER Havana - The leading: smoking variety. Commands a high price for cigar stock. Price: Pkt., 5e; $1 / 2$ Oz., 15e; Oz., :30e; $1 / 41$ b., 90e.

GOLD LEAF-A cross between the Yellow Prior and Oronoka; good either for wrappers or fillers; also fine for pipe or chewing. Price: Pkt., 5e; 1/2 Oz., 15e; oz., 30e; $1 / 4$ lb., 90c.

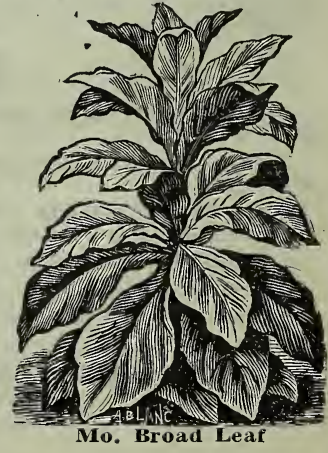




\section{SQUASH sposit kerentars}

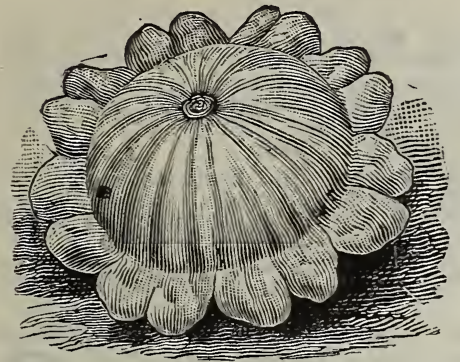

Mammoth White Scallop Bush

One ounce of the small seeded varieties will plant 40 hills; of the large seeded, 15 hills. MAMUOTH WHITE SCALLOP BUSF-This handsome, large white variety is about twice the size of the Early White Scallop Bush, purer white color. In quality it is much superior to the above and is very early. Price: Pkt., 5c; oz., 10c; $1 / 41 b ., 15 c$.

YELLOW SUMMER CROOKNECK--This famous variety is an ideal baking sort as well as being enormously productive. It is of a bush form. Small crooked neck, with warts. Price: Pkt., 5c; oz., 10c; 1/t1b., 15c.

EARLY WHITE SCALLOP BUSH-( White Patty Pan or Cymlins)-A beautiful white Squash of light cream color, large size, flat. Elegant for home use. Price: Pkt., 5c; oz. 10c; $1 / 41 b ., 15 c$.

BOSTON MARROW-Oval shape; skin yellow; flesh orange colored and fine grained. We consider this one of the finest squashes ever grown. Frice: Pkt., 5c; oz., 10c; $1 / 41$ b., 20c.

IMPROVED STRIPED CUSHAW-One of our new Squash introductions. It is of a beautiful variegated coloring, producing stripes of a mottled effect. Very prolific and of medium size; an ideal baking variety. Price: Pkt., 5́c; oz., 10c; 1/4lb., 25c.

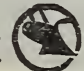

CHICAGO WARTED HUBBARD-Is an exceptionally good keeper. Is larger than the original Hubbard and a long keeper. It is also of fine quality. A great improvement over the old Hubbard. Price: Pkt., 5c; oz., 10c; 1/1b., 25e.

MAMMOTH CHILI-It is of the lighest value as a stock food, far exceeding ordinary pumpkins in this respect. Has reached the enormous weight of 292 pounds. Price: Pkt., 5c; oz., 10c: $1 / 4$ lb., S0c.

WINTER CROOKNECIK-Skin green, mottled and striped like Cushaw Pumpkin. Long, solid

neck. Dry and sweet flesh. Fine keeper. Price: Pkt., 5̌c; oz., 10c; $1 / 4 \mathrm{lb}$., 15c.

HUBBARD-The leading Squash for fall and winter use. Flesh dark yellow, fine grained. Price: Pkt., 5c; oz., 15c; $1 / 41$ b., 40c.

ITALIAN MARROW-A large, oblong variety, producing fruit which is dark green at first kecoming marbled and striped with yellow and lighter green as they mature. Price: Pkt., 5e; $1 / 20 z$., 10c; oz., 20c; $1 / 4$ lb., 50c.

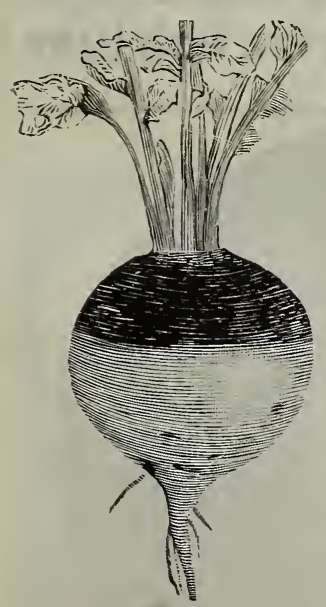

\section{TURNIP (Ruebe)}

One ounce will sow 150 feet of drill. EXTRA EARLY PURPLE TOP MILANFully a week earlier than any variety. Flat and smooth, of medium size. Pure white flesh of choice quality. A good keeper. F'ire table variety to grow either in spring or fall. Prize: Pkt., 5c; oz., 10c; 1/41b., 25c.

PURPLE TOP WHITE GLOBE-This famous purple top turnip is very desirable for home gardens, and a favorite with market gardeners on account of its shape, size and beauty. Flesh rure white, with a red of purple top. Price: Pkt. 5c; Oz., 10c; $1 / 41 b ., 15 c$.

PURPLE TOP FLAT STRAP MEAF--The standard variety. Pure white, except the purple outer skin above ground. Price: Pkt., 5c; oz., 10c; 1/4lb., 15c.

POMERANIAN WHITE GLOBE-The king of all mammoth white Turnips. Immense white, globe-shaped roots. Considering the size, it matures early. A very good autumn variety. Price: Pkt., 5c; 0z., 10c; 1/41b., 15c.

YELLOW OR AMBER GLOBE-Is the staple yellow Turnip, both for table and for feeding stock. Heavy cropper and keeps well. Flesh firm and sweet. Price: Pkt., 5c; oz., 10c; $1 / 4$ lb., 15c.

WHITE EGG-A very quick growing fall Turnip. Should be sown in August. Oval or egg shaped, flesh very firm and fine grained, flavor mild and sweet. A fine cooking variety. Price: Pkt., 5c; oz. 10e; $1 / 41 b ., 15 e$.

Cowhor -A beautiful, long, fine-grained Turnip, very sweet. Pure white, green top. In shape similar to a cow's horn. Generally used for stockfeeding. Price: Oz., 5c; 1/4lb., 15c.

SEVEN TOP-Grown only for the tops, which are used for greens or salad in the South. Price: Pkt., 5c; oz., 10c; $1 / 41 \mathrm{~b} ., 15 \mathrm{c}$.

\section{RUTABAGA}

AMERIC A YELLOW PURPLE TOP-The most satisfactory variety of Rutabaga to grow for either family use or stock feeding. Is very hardy and productive. Flesh, yellow, solid and sweet. Price: Pkt., se; oz., 10c; 1/4lb., 15e. 


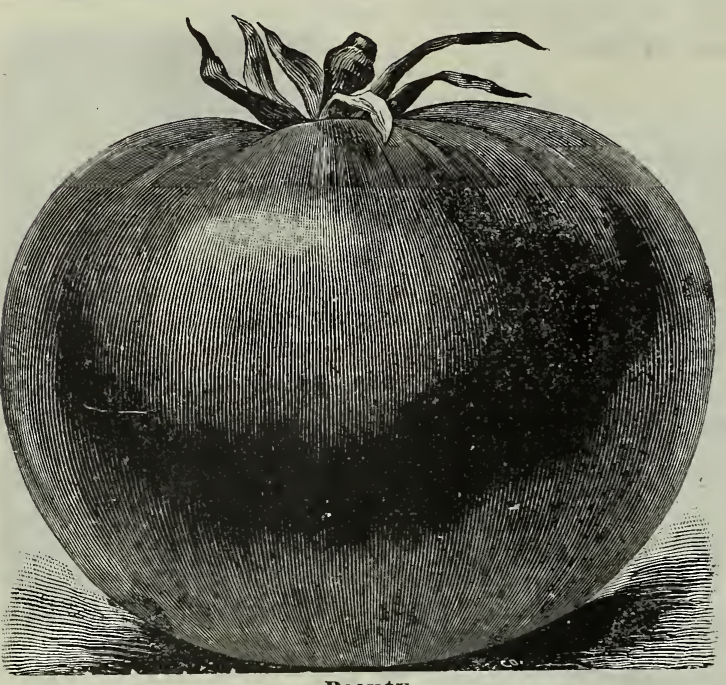

Beauty

ST. L. S. CO'S IMPROVED WHITE'S EXCELSIOR - Our new strain of this famous Tomato is superb. It is of a dark, glossy purplish red, very large and also very solid. As a satisfaction giving variety it is second to none. We regret for lack of space we cannot go into details further. Take our advice and try it this season. Price: Pkt., 5e; $1 / 20 z$., 15e; oz., 25e; 1/4 lb., 75e.

SPARK'S EARLIANA-Grow it for early market in preference to any other old standard sort, it being a full week earlier. It supersedes the Atlantic Prize by far, because the fruits are not only remarkable for their earliness, but for their large size, perfect form, bright red color. Price: Pkt., 5e; $1 / 20 z$., 15e; oz., 25e; $1 / 41$ b., 75e.

NEW GLOBE-Its form is of a globular shape, hence its name. Very solid, of a purple color, very deep from stem to blossom end. Very early; a good market sort; fine for packing in small baskets for market. Price: Pkt., 5c; 1/20z., 15e; oz., 25e; 1/41b., 75c.

MAMMOTH LARGE RED-This famous variety is enormous both in size and yield, it being one of the largest smooth, round red Tomatoes. Later than Mangus and much larger and of a clear, bright red color. Flesh is thick and heavy, and there are but few seeds. Price: Pkt., כe; 1/20z., 15e; oz., 25e; $1 / 4$ 1b., 75e.

BUCKEYE STATE-A beautiful, large, smooth, round variety. It is an immense cropper bearing its fruit in large clusters, often six to eight in a single cluster. Very showy and striking when displayed for sale. Prize: Pkt., 5e; 1/20z., 10e; oz., 20e; $1 / 41$ b., 75e.

HUSI, OR GROUND CHERRY - A favor ite canning or preserving variety. Price: Pkt., 5e; $1 / 2$ oz., 15c; oz., 30c.

PEACH-Size, shape and color of a peach. A great favorite everywhere. Price: Pkt., 5c; $1 / 2$ oz., 15e; oz., 25e.

YELLOW PEAR-Excellent for "putting up." Can be found in nearly every garden. Price: Pkt., 5c; 1/20z., 15e; oz., 25e.

YELLOW PLUM-Popular small yellow for preserving. Used extensively by preserving factories. Price: Pkt., 5e; $1 / 20 z$, 15e; oz., 25e.

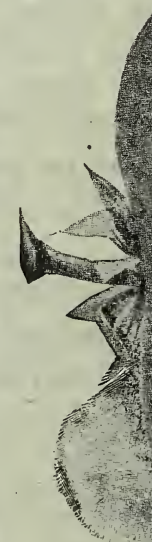

\section{TOMATOES}

(Liebesapfel)

One ounce will produce about 2000 plants.

LIVINGSTON'S BEAUTY - This standard Tomato is well known. Grows in large clusters and retains its large size late in the season. It is very valuable for shipping and for early market. Color, "purple." Price: Pkt., 5e; $1 / 2$ oz., 10e; oz., 20e; $1 / 4$ lb., 60c.

DWARF CHAMPION-This famous Tomato is a favorite home garden variety. Its stiff, upright stocks are so sturdy as to hold the fruit well above the soil, even without stakes or supports. It is earlier and larger than most extra

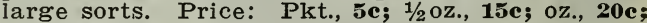
$1 / 41 \mathrm{~b}$., 65c.

STONE-This celebrated Tomato is without exception the standard leading variety for canning. It has come to be recognized as one of the best of all the standard sorts. Originated by our Mr. Nichol. The fruit is of large size, perfectly smooth, and of best quality. Its shape, color and quality adapt it to the fancy trade. Color, bright red. We urge every one to plant freely of this wonderful variety. Price: Pkt., 5e; $1 / 20 z ., 10 c ;$ oz., 20e; $1 / 41 b$. 50c.

\section{PONDEROSA}

$\mathbf{T}$

HIS mammoth Tomato is a great favorite for the home garden because of its immense size, stonelike solidity, delicious quality and beautiful appearance. Contains very few seeds; is all "meat" and of perfect form. Color, glowing crimson. A very heavy yielder. Price: Pkt., 5e; $1 / 2$ oz., 15e; oz, 30e; $1 / 41 b$, \$1.00.

GOLDEN BALL-A beautiful, large, round, yellow sort. Very fine flavored. Excellent for table use. Price: Pkt., 5e; $1 / 2$ oz., 10e; oz., 20c; $1 / 41 b ., 60 c$.

\section{New Wonder Magnus, Early Dawn} SEE PAGE 8

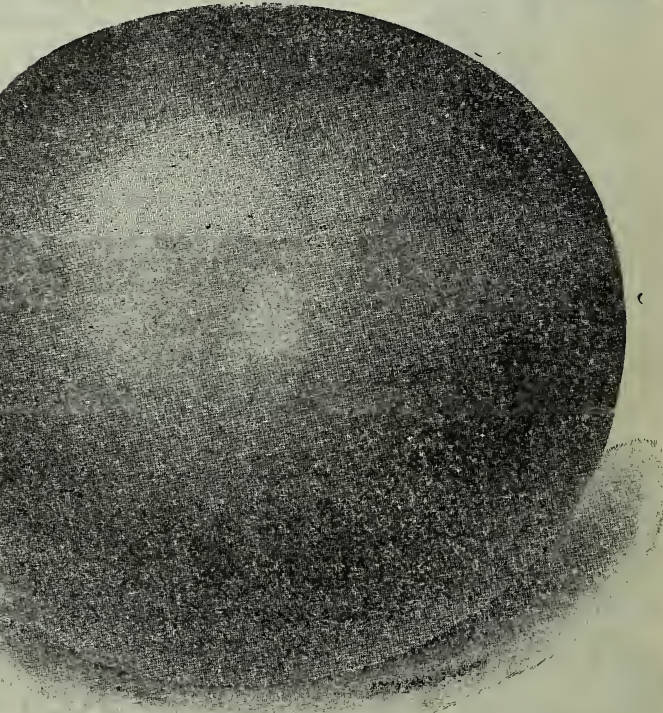

New Globe. 


\section{Vegetable Plants and Roots}

Prices Subject to Change.

Asparagus Roots, Columb'n Mammoth.. \$0 20 Palmetto

Cabbage, Extra Early Jersey Wakefield. 15

All Season .................. 15

St. Louis Late Market .......... 15

Cauliflower, Earliest Dwarf Erfurt.... 2

Early Snowball .........

Chives, per clump, $10 \mathrm{c} \ldots \ldots \ldots \ldots \ldots \ldots \ldots 10$

Celers, White Plume $\ldots \ldots \ldots \ldots \ldots \ldots \ldots \ldots$ 1 15 Golden Self Blanching ......... 15

Egg Plant, Improved Oval Spineless.... 25

Kohl Rabbi ..................

Horse Radish Roots ................ 15

Lettuce $\ldots \ldots \ldots \ldots \ldots \ldots \ldots \ldots \ldots \ldots \ldots$

Peppermint, each, $10 c \ldots \ldots \ldots \ldots \ldots \ldots 100$

Rhubarb, 2-year-old, each, $15 \mathrm{c} \ldots \ldots \ldots . .10$ 1-year-old, each, $10 \mathrm{c}$. . . . .

Sweet Potatoes, Red, yellow and white

65

\begin{tabular}{|c|c|c|}
\hline 50 & 100 & 1000 \\
\hline 50 & $\$ 075$ & $\$ 500$ \\
\hline 50 & 75 & 500 \\
\hline 3 & 55 & 350 \\
\hline 35 & 55 & 350 \\
\hline $\mathbf{3 5}$ & 60 & 450 \\
\hline 90 & 150 & ... \\
\hline 90 & 150 & \\
\hline . & & \\
\hline & 50 & 400 \\
\hline & 50 & 400 \\
\hline 90 & 150 & . \\
\hline 35 & 65 & \\
\hline 40 & 60 & 400 \\
\hline & 50 & 400 \\
\hline 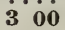 & $\ddot{5} \ddot{00}$ & \\
\hline
\end{tabular}
not less than $50 \ldots \ldots$.

Cll or Bull Nose .......... 20

, Ponderosa ................ 20

Magnus $\ldots \ldots \ldots \ldots \ldots \ldots \ldots \ldots \ldots$ 15

White Excelsior ............ 15

Dwarf Champion ......... 15

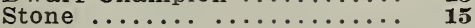

2535300

60100

60100

60100

70. 125

$60 \cdot 100$

60 100

601100

60100

No'TE-In order to meet the demand for strong vigorous Tomato plants we offer plants of all varieties listed above. Special large transportation plants for those who prefer to have them. These plants, when set out, grow very rapidly, producing handsome, well-shaped vines that yield far better and earlier than ordinary transplanted stock.

PONDEROSA AND MAGNUS-Price: Per doz., 40c.

ALL OTHER VARIETIES-Price: Per doz., 35c.

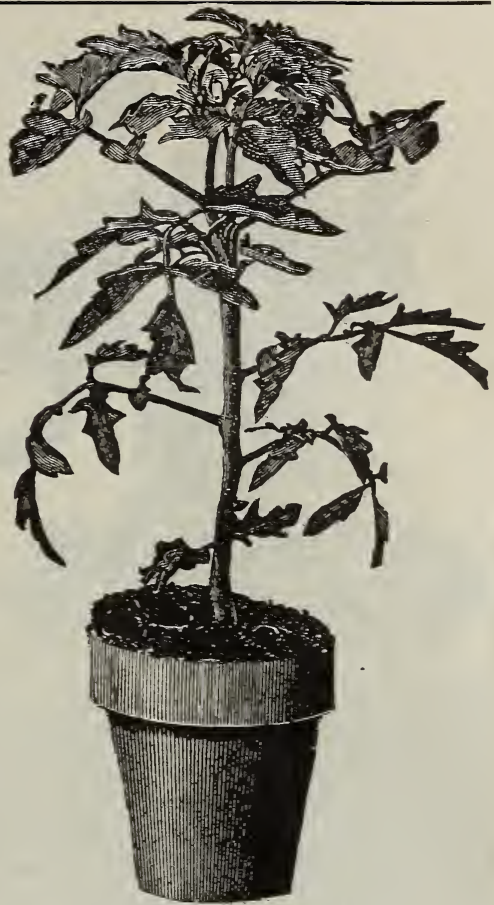

Potted Tomato Plants WE ALWAYS REFUSE

\section{Mushroom Culture cammenem nowe}

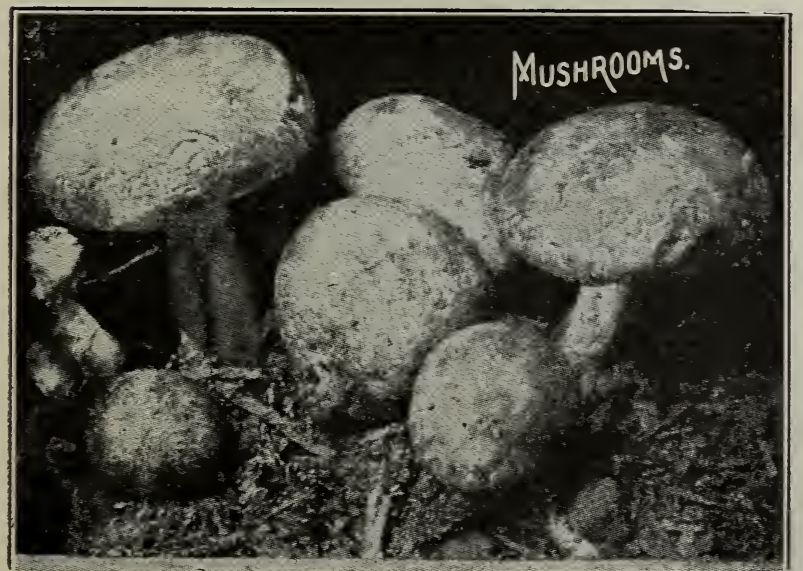

MAY be grown in a great variety of situations-a dark room, cellar, stable or temperature of about 50 or 60 degrees can be kept, is suitable. For materials for the bed, use fresh horse manure, free from straw or chips, and good loamy soil. Some growers use the manure unmixed with loam, after first having well fermented it by alternately piling up and mixing for a few weeks; but it is undoubtedly better not to allow the manure to heat much before forming the bed. Use onefourth to one-third loam, the rest manure. Mix very thoroughly and upon a dry, firm bottom make the bed of this mixture, about four feet wide, and of any desired length. Build it up evenly, pressing it down very fimly, and leave it about a foot high. It will shortly begin to heat. Use a thermometer to thrust into bed, and note the temperature. When the heat has partially subsided, leaving a temperature of 70 to 80 degrees, put in the spawn. Pieces from the size of walnuts to that of eggs are placed in the bed about a foot apart, deep enough to cover them well, and the manure pressed down. Let it remain thus ten or twelve days; then cover with two

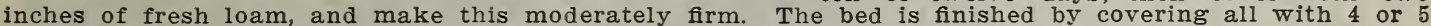

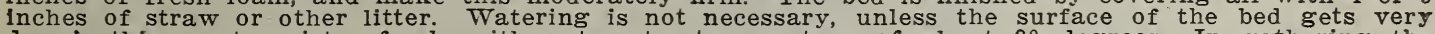

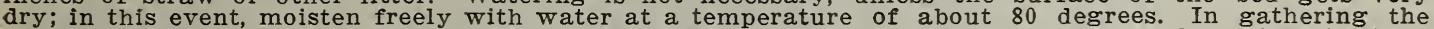

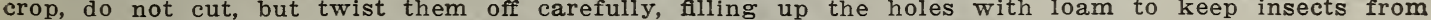
the roots. In six or eight weeks from spawning the beds, mushrooms should appear.

GENUINE ENGLISH MILLTRACK SPAWN-Large bricks, 20c; five bricks, \$1.00. One pound English Spawn will spawn about 6 square feet.

TISSUE CULTURE SPAIVN-By far the best. It gives better results for the amateur. A heavy

producer. 1 brick, for ten square feet, 25c; 10 brick, for 100 square feet, \$2.00. 

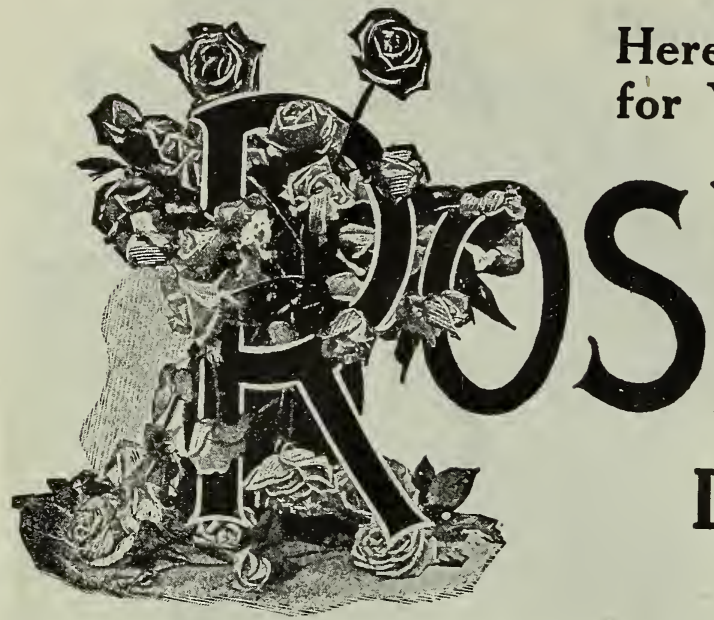

AMERICAN BEAUTY-Large, globular; deep pink, shaded with carmine; delicious odor.

PAUL NEYRON-Deep, shining rose, very large flowers. Long, straight stems.

FRAU KARL DRUSCHKI-This is the ideal hardy white Rose, pure in color, perfect in form; strong grower and remarkably free flowering; superb in every way.

GENERAL JACQUEMINOT-Brilliant scarletcrimson; an old favorite and one of the best known Roses in cultivation; does well everywhere.

GRUSS AN TEPLITZ-This grand rose has proved one of the best and most valuable Fardy Crimson Ever-blooming Roses for garden planting. The color when first opening is dark rich crimson passing to velvety fiery red, one of the very brightest Roses we know. Price: Each, 35e; 3 for \$1.00.

MRS, JOFN IAING-Soft pink; large and of fine form, produced on strong stems; exceedingly fragrant; one of the most valuable varieties and flowers continuously in the open ground. The most beautiful rose of recent introduction.

MERVEILLE DE LYONPure white, shaded and
marked with satiny-rose; flowers very large, double, and of a beautiful cup shape larger. A superb variety.

\section{MOSS ROSES}

BLANCHE MOREAU - A beautiful white and a free bloomer.

PANACHE-A large double red, of an exquisite shade. Large plants. Price: Each, 40e.

\section{DWARF \\ BABY RAMBLER}

A beautiful plant when in bloom, being very small and full of blooms and clusters: well known. Price: Each, 25e; per doz., \$2.50.

All varieties not priced above; each 30e; per doz., \$3.00.

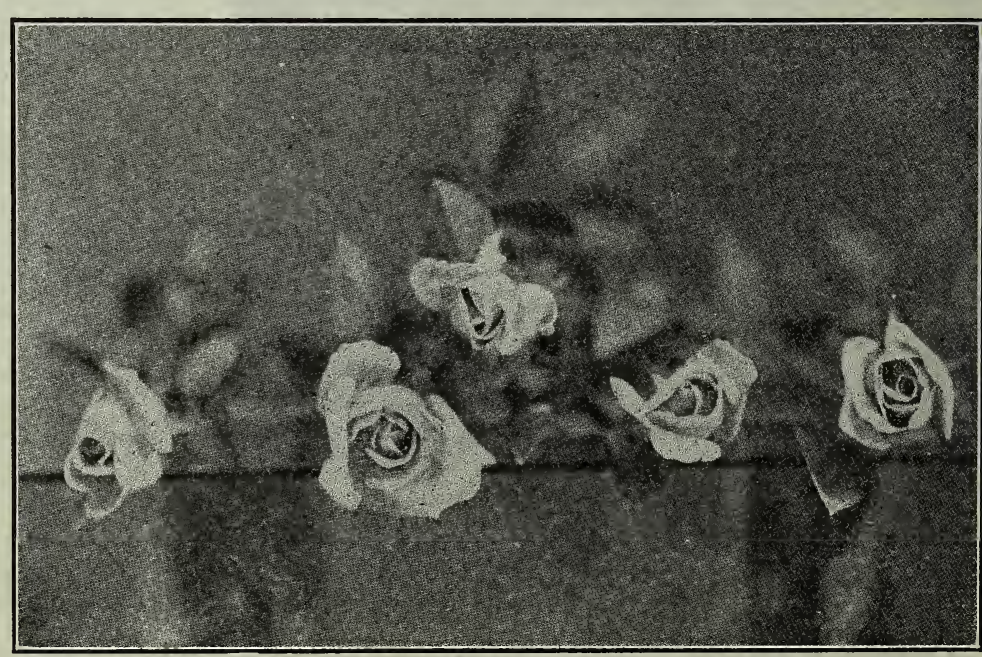




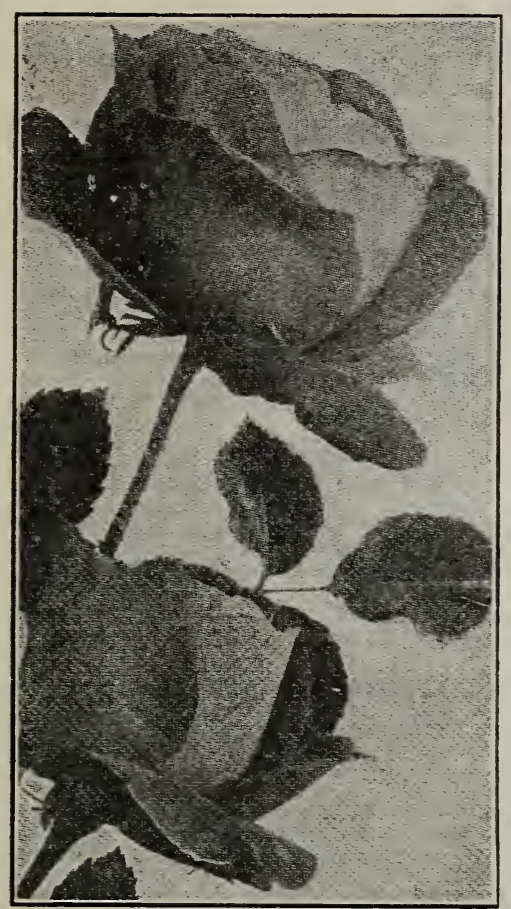

\section{DWARF ROSES-Continued}

RICHMOND-One of the best red Roses yet produced. It comes to perfection with very little care. It is a constant bloomer, very fragrant, with a color approaching a deep scarlet in tone. It has long pointed buds on tall, straight stems, with elegant dark foliage. A superb Rose in every sense of the word. Price: Each, 35e; per doz., \$3.50.

PERLE DES JARDINS-Fine straw yellow; sometimes deep canary yellow; very large and full, and of the most perfect form; one of the finest roses grown; steps at once into fame as the finest yellow Rose we have.

BON SILENE-Buds of beautiful form; an unusually free bloomer; color, deep rose-shaded carmine.

HERMOSA-Bright rose, a most constant bloomer.

\section{Climbing Roses}

\section{CRIMSON RAMBLER}

Have you a fence or tree stump to cover, or a veranda or trellis? Try a Climbing Rose-there's nothing beter for covering it and nothing prettier. None is more popular than the CRIMSON RAMBLER. It makes vines 10 to 12 feet high after the first year, and a mass of flowers. Price: Each, 25c; per doz., \$2.50.

\section{YELLOW RAMBLER}

The color is a decided yellow, growth very vigorous; in habit the same as the Crimson.

\section{DOROTHY PERKINS OR PINIK RAMBLER}

A seeding of the famous Crimson Rambler. Blooms in clusters of from $\&$ to 25 flowers each, of a delicate rosy pink shade, suffused salmon and yellow at the base. Of vigorous climbing habit.

\section{WHITE RAMBLER}

The flowers are very double and full, of medium size, pure snowy-white, and borne in large clusters continuously throughout the whole season.

\section{CLIMBING METEOR}

The finest crimson Everblooming Climbing Rose in cultivation.

\section{BALTIMORE BELLE}

Pale blush, variegated carmine, rose and white, very double. Flowers in beautiful clusters.

\section{BILLIARD ET BARRE}

A beautiful orange yellow; an elegant variety for trellis or veranda; good bloomers.

Price of any of abeve not priced; each, 30c; per doz., \$3.00.

\section{Tree Roses}

The Tree Roses are grafted on hardy stems four to five feet high and thus form tree shapes. When in full bloom they are very handsome. We offer an assortment of white, pink, scarlet and crimson varieties. As these trees are annually imported from Holland. Price: Each, 75c; per doz., \$8.00.

AMERICAN BEAUTY-Beautiful red, shaded.

FRAU KARL DRUSCHKI-White.

GRUSZ AN TEPLITZ-Crimson.

JOHN HOPPER-Rose with Crimson center.

MRS. JOHN LAING-Soft rose.

CLINE FORESTIER-A beautiful shade of yellow.

DUKE OF CONNAUGHT-Velvety crimson, fiery blush.

GLORIE DE DIJON-A fine double salmon shade.

MRS. R. G. CHARMAN CRAWFORD-Very exquisite; a deep, rosy pink.

BARONESS DE ROTHSCHILD-Light rose shade; large flowers.
Rambler Roses will make that eye-sore spot look beautiful

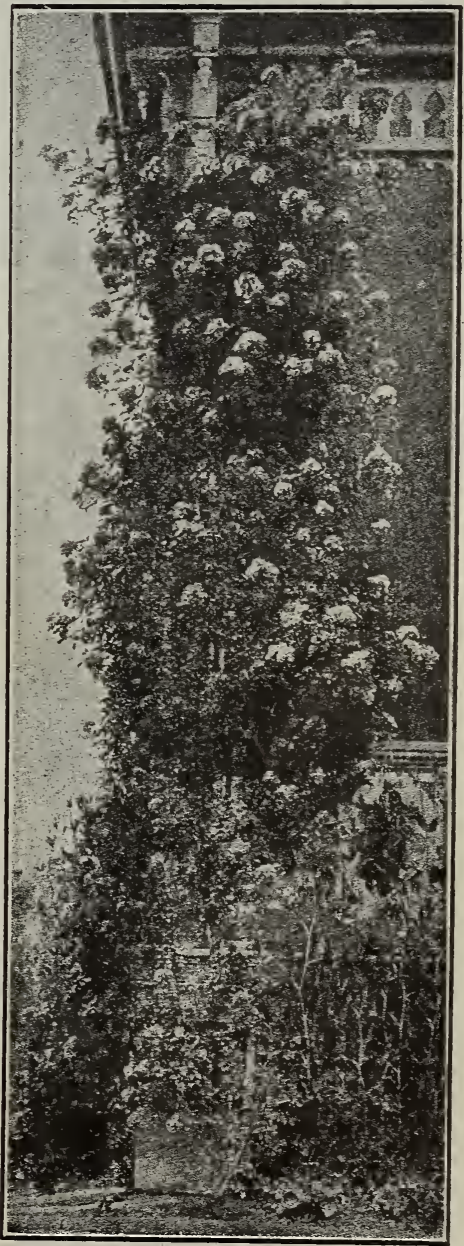




\section{0}

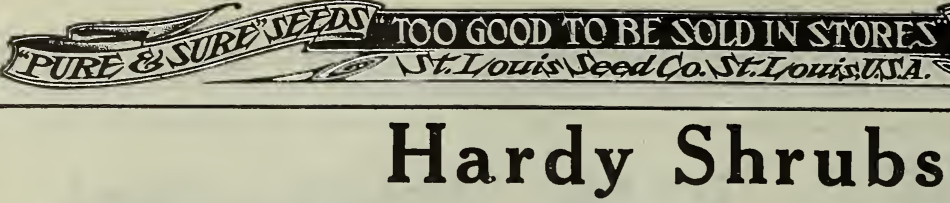

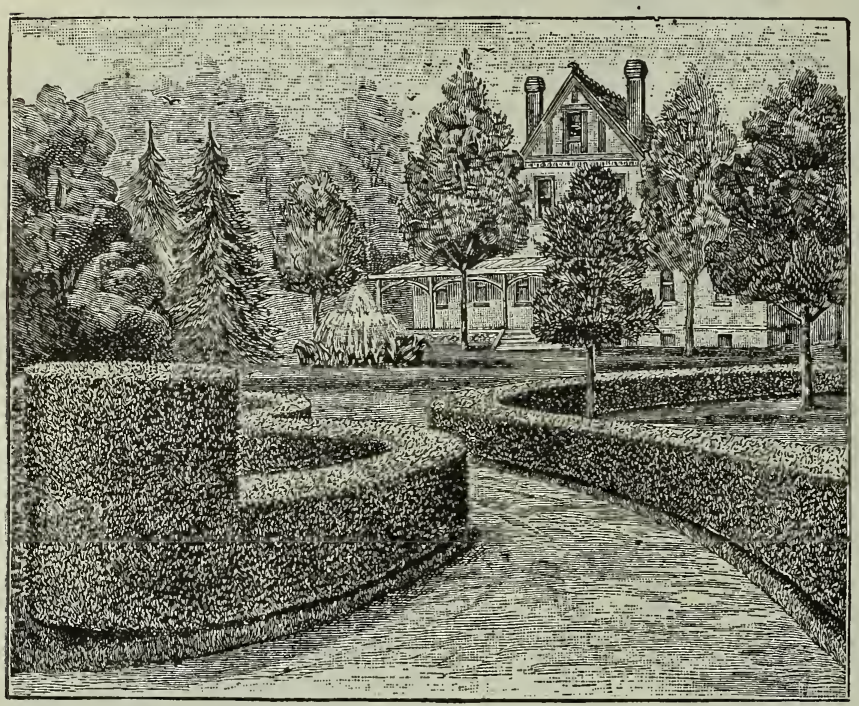

California Privet

\section{Hydrangea Paniculata Grandiflora}

This is one of the most hardy shrubs in cultivation. It attains a height of 6 to 8 feet, and is perfectly hardy in all parts of the country. The flowers are white, borne in immense pyramidal pinnacles nearly a foot in length. It commences flowering in July and continues until November. This is the finest fiowering shrub for cemetery planting we know of; flowers turn a lavender color toward end of season. $2 \frac{1 / 2}{2}$ to $31 / 2$ feet. Each, 25e; per doz., \$2.25.

TREE HYDRANGEA-A tree shape Will make beautiful specimens for the lawn. Fine flowering variety; 4 to 7 feet high. Price: Each, 60e; 4 for \$2.00.

\section{Deutzia}

Beautiful, showy Japanese shrubs of the highest ornamental merit, adapted to all good soils. Their clean foliage, upright, dense growth and free flowering nature render them especially valuable. Colors, pink and white; 2 to 3 feet. Price: Each, 35e.

\section{Lilac or Syringa}

PERSIAN-Of more slender growth and finer foliage, as well as more fragrant, than the common Lilac. We offer these in white; 2 to 3 feet. Price: Each, 35c.

LARGE PURPLE-Very free bloomer of large flowers; an excellent variety; 2 to 3 feet. Price: Each, 35e.

\section{Viburnum}

(Snowball)

One of the most handsome bushes for the vard, known as Snowball. Tree; of large size, with globular clusters of pure white flowers, blooming latter part of May; admired by home lovers everywhere; 3 to 4 feet. Price: Each, 35c.

\section{California Privet}

F ALL the shrubs which have been tried for hedging, none can compare with this. Of easy growth and splendid foliage, free from insects. Its inexpensiveness alone would give it first place for the purpose. It is now planted by the million annually. It is of free growth, and succeeds under the most adverse conditions, such as under dense shade of trees, where other plants would not exist. Price: 2 to 3 feet high, ten for 75c; 25 for $\$ 1.50 ; 50$ for \$2.50; 100 for $\$ 4.50$.

18 to 24 inches high, \$3.50 per 100 .

\section{Spiraea}

VAN HOUTWE-The grandest of all the Spiraeas. It is a beautiful ornament for the lawn at any season, but when in flower it is a complete fountain of white bloom, the foliage hardly showing. An early bloomer. Twoyear-old clump, 2 to 3 feet high, each 35c; 10 for \$2.50.

\section{Hybiscus Syriacus}

\section{(Althea or Rose of Sharon)}

These are very fine hardy, free growing, flowering shrubs of very easy cultivation and very desirable on account of their late summer blooming. Should be in every of colors and shades; remains in bloom until flowers are cut down by frost. We have the following separate colors: Red, Blue, Pink, White. About 3 feet high, 4 to 6 branches each, 20c.

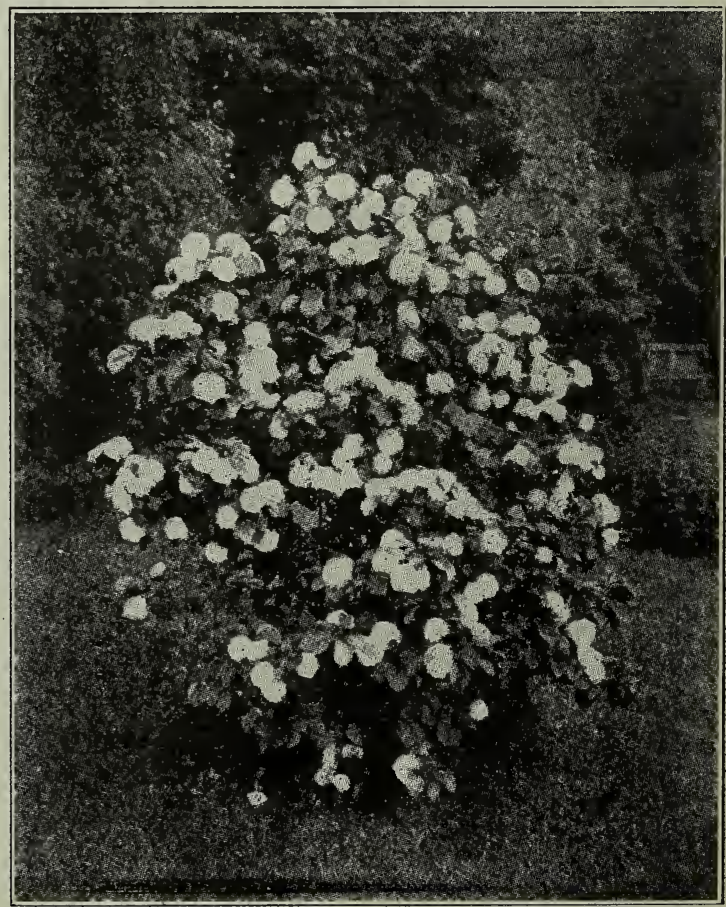

Snow Ball 


\section{Hardy Ornamental Climbers}

\section{Clematis}

One of the most beautiful and showy climbers we have. The flowers are of enormous size, many growing to 7 inches in diameter. Owing to their very hardy nature, they are easily a favorite, requiring very little care. For pillars, trelises and for running over rockwork or trees it cannot be surpassed.

PAVICULATA-One of the best varieties. Fragrant white flomers, borne in clusters in great profusion. Extra large roots, each, 25e.

JACKMANNII-Large deep purple Extra large roots. Each, 40c.

HENRYY-Color, white. Size of the Jackmannii. Extra large roots. Each, 40c.

MME. EDOUARD ANDRE - Dar pink, size of Jackmannii. Extra large roots. Each, 50c.

TILLE DE LYON-New Crimson Each, 40c.

NELLY MOSER-Beautiful white with red stripe. A new variety of great merit. Each, 40c.

DUCHESS OF EDINBURG-A fine large double pure white. Each, 40c.

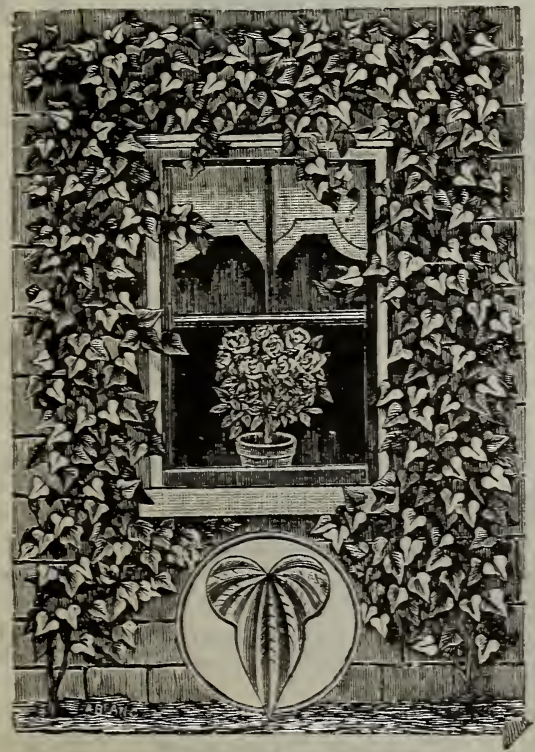

Cinnamon Vine.

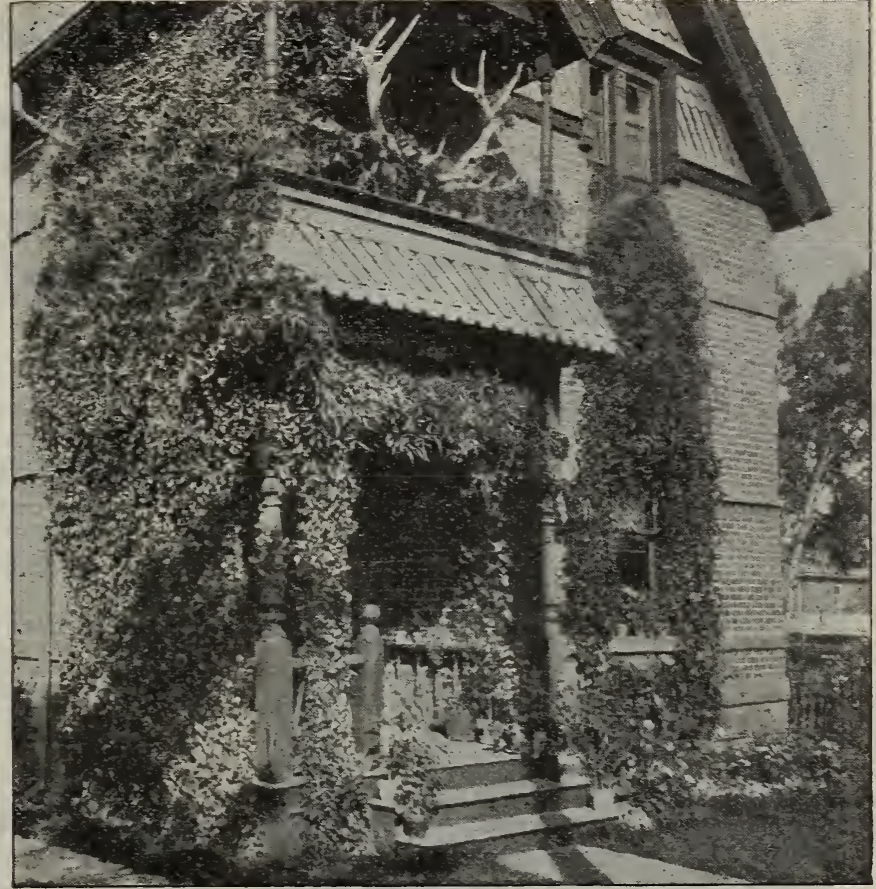

Clematis Paniculata

\section{Ampelopsis Veitchii}

(Boston or Japan Iry)

The finest climber for training over brick walls, as it clings firmly to the smoothest surface, covering it smoothly and densely with fresh, green, heart-shaped leaves in summer which change in the fall to the bright autumn colors. It likes a rich soil. Strong plants. Each, 20c.

QUIYQUEFOLI (Virginia Creeper)-The well-known climber, clinging to any surface, covering the same rapidly. Dark green foliage changes to brilliant autumn colors in the fall. Strong plants. Each, 25c.

\section{Cinnamon Vine}

This beautiful climber possesses the rare quality of emitting from its flowers the delightful odor of cinnamon, and is very appropriately called the cinnamon vine. Perfectly hardy, the stem dying down every autumn, but growing again so rapidly as to completely cover any trellis or arbor very early in the season. With its beautiful heart-shaped leaves and clusters of delicate white flowers and delicious cinnamon odor, it is a most desirable climber. Price: Each, 5e; 6 for 25 c.

\section{Bignonia Radicans}

(Trumpet Creeper)

A splendid climber for rapidly covering unsightly surfaces. Large orange trumpet flowers borne in profusion after the plants get fair size. Strong plants. Each, $25 \mathrm{c}$. 


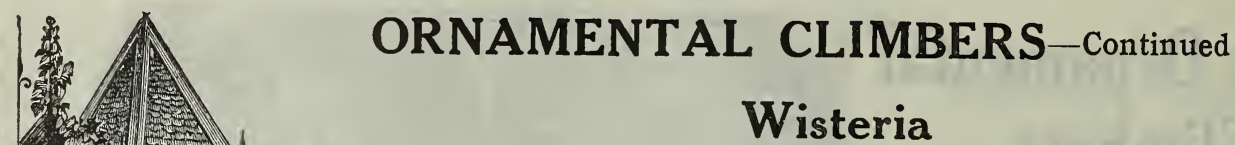

A beautiful hardy climber; will grow in one season about 20 feet high;
flowers in clusters, pale blue.
W. SINENSIS (Chinese)-Flowers in clusters; pale blue; sometimes gives
a second crop of flowers in the fall. Strong plants, 25e each. Extra strong,
35e each.
W. SIENESIS ALBA-Of similar habit to Sinensis, with pure white flow-
ers. Strong plants, 35c each; extra strong, 50e each. H.

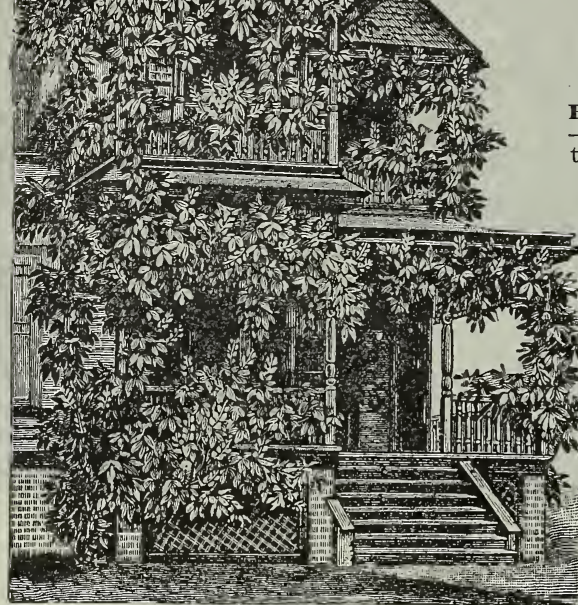

Wisteria
L. JAPONICA var. HALLEANA-Color white, changing to yellow; very fragrant; blooms from June to November. Each, 30c. L. PERICLYMENUM var. BELGIA-(Monthly Fragrant) -A fine, rapid growing variety; flowers large and very fracrant; color, red and yellow; a constant bloomer. Each, 30c.

L. SEMPERVIRENS -(Scarlet Trumpet) - A strong, rapid grower tire season; bright red, trumpet shaped flowers. Each, 30c.

\section{Madeira Vine}

A very free bloomer, with thick, glossy leaves. Suitable for trellis, rockwork, hanging baskets, etc. Price: Bulbs, 25e per 1b.

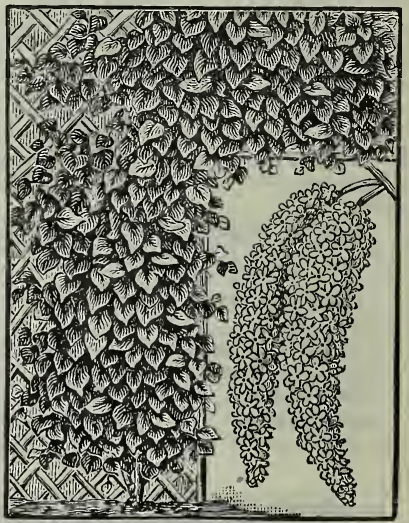

Madeira Vine

\section{Bedding Plants}

All sorts priced at $\$ 1.00$ or less per dozen, 10 cents each; at $\$ 1.50$ per dozen, 15 cents each.

AGERATUM-Dwarf, blue, 60e per doz.

ALTERNANTHERA-Red, green and striped. 50c per doz.

ASTERS (China)-In six distinct colors. Ready from May 10 th to June 15 th. 50e per doz.

CALADIUMS-See page 38 for bulbs. CANNAS-See page 38 for bulbs and plants.

CHRYSANTHEMUMS-Assorted colors. 75e per doz.

CANDYTUF'T-60e per doz.

CARNATIONS-60e per doz.

CALLIOPSIS-50e per doz.

Coleus (Golden - Beauty) -

Crimson, 75e per doz.

COSMOS (Mammoth Perfection) -White, pink or crimson, 60c per doz.

CENTUREA (Gymnacarpa) 60e per doz.

DIANTHUS-60e per doz.

GERANIUMS - Large plants, $\$ 1.50$ per doz.

LANTANAS-75e per doz.
WEEPING LANTANA-\$1.50 per doz.

LOBELIA-Dwarf blue bedding; ready in May and June, $75 \mathrm{c}$ per doz.

LARKSPUR-Assorted, 75e per doz.

NASTURTIUM-Dwarf and tall, 75e per doz.

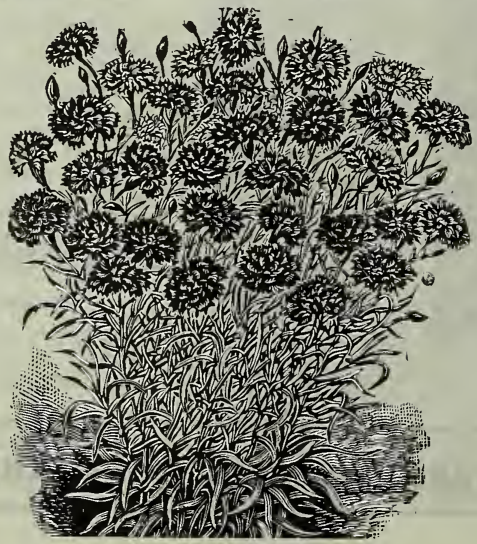

PANSIES-Assorted colors, 50c per doz.

PETUNIA-Double-fringed, 1.50 per doz. Single-fringed; mixed colors, $\$ 1.00$ per doz.

PHLOX-Annual. 60c per, doz. PINKS-Hardy garden. \$1.00 per doz.

SAIVIA SPLENDENS (Scarlet Sage)-Large plants, \$1.50 per doz.

STOCKS- $\$ 1.00$ per doz.

SWEET ALYSSUM - Dwarf white, 60c per doz.

SWEET WILLIAM-Mixed colors. $75 e$ per doz.

VERBENAS - Mammoth, 60c per doz.

VINCA-\$1.00 per doz. 


\section{St. Louis Seed Co.'s Hardy Perennial Plants}

The demand for hardy perennial plants has been increasing, and today more of this class of flowers are planted than in the past five years collectively. When once planted they are a source of constant pleasure succeeding years.

These are strong plants from 3 -inch pots, which have been wintered in cold frames, and should flowel well the first season. This is the most desirable size for planting for those who wish to make a large perennial border.

\section{Alyssum}

SAXATILE COMPACTUM (Basket of Gold)-An indispensable plant for the rockery or border, growing one foot high and producing early in the summer masses of broad, flat heads of bright yellow flowers. Price. Each, 15e; per doz., \$1.50.

\section{Achillea (Milloil or Yarrow)}

MILLEFOLIUM ROSEUM-Flowers pink, in dense heads; produced all summer; height, 18 inches. Price: Each, 15c.

THE FEARI-The flowers are borne in great profusion and are pure white; double; blooms all summer, 2 feet. Price: Each, 15c.

\section{Anemones (wind Flowers)}

These beautiful Wind Flowers are one of the most important hardy plants. While they begin blooming early in August, they are more especially valuable on account of their continuing in full beauty until cut down by rard frost. All are excellent for cutting.

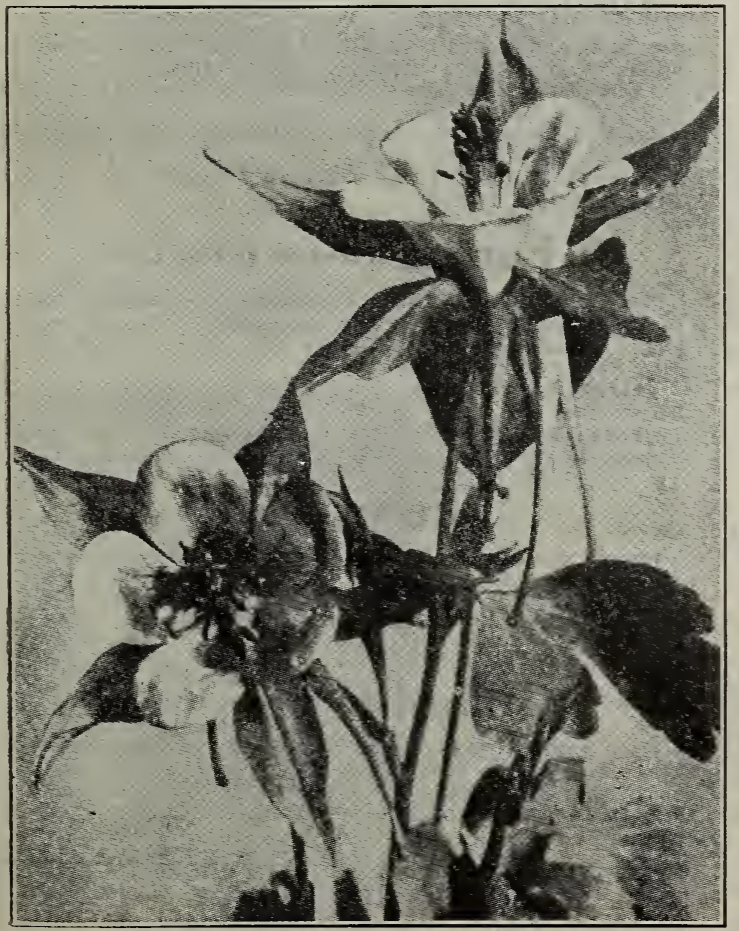

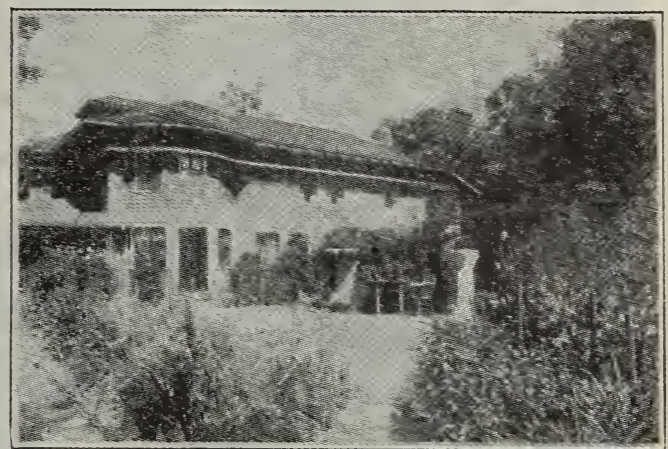

Showing Improvements of Home Grounds

PRINCE HENRY-Semi-double, dark red. Rare, unequaled. Price: Each, 25e.

QUEEN CHARLOTTE-Large, double pink flowers. The most popular of all. Price: Each, 25e.

SYLVESTRIS-White flowers. Stands shade: one foot. Price: Each, 20c.

\section{Aquilegia (Columbine)}

These are the most beautiful hardy plants, with graceful spurred flowers of charming colors. They are not at all particular as to soil or location, but like a sunny position.

COERULE HYBRIDA-Each, 15c.

\section{Anthemis (Marguerite)}

A very satisfactory summer flowering perennial, succeeding in poorest soil. Blooms entire summer, 15 inches.

TINCTORIA-Dense, bushy habit, large golden yellow flowers. Price: Each, 15c.

\section{Hardy Asters}

These are among the showiest late flowering, hardy plants, giving a wealth of bloom at a season when most other hardy flowers are past. Grow in any soil, they bloom in September and October.

NOVA ANGLIA-Large, bluish purple, with yellow center; September and October; four feet. Price: Each, 15c.

RYECROFT-Pink; soft, rosy pink; 4 feet. Price: Each, 15e.

SNOWFLAKE-Pure white, blooms profusely; September and October, $2 \frac{1 / 2}{2}$ feet. Price: Each 15e.

\section{Bellis Perennis (English Daisy)}

Improved double flowering; white and pink. Price: Each, 10e; per doz., 75e.

\section{Bleeding Hearts (Dielytra)}

Graceful sprays of heart-shaped pink and white flowers; blooming in May or June; $1 \mathrm{~s}$ inches: Price: Each, 15c.

\section{Centaurea (Hardheads)}

Plants of easy culture, thriving in sunny positions. Splendid for border planting and cutting.

IONTANA (Perennial Corn Flower)-Violet blue; July to September; height 2 feet. Price: Each, 15e. 


\section{PERENNIAL PLANTS-Continued}

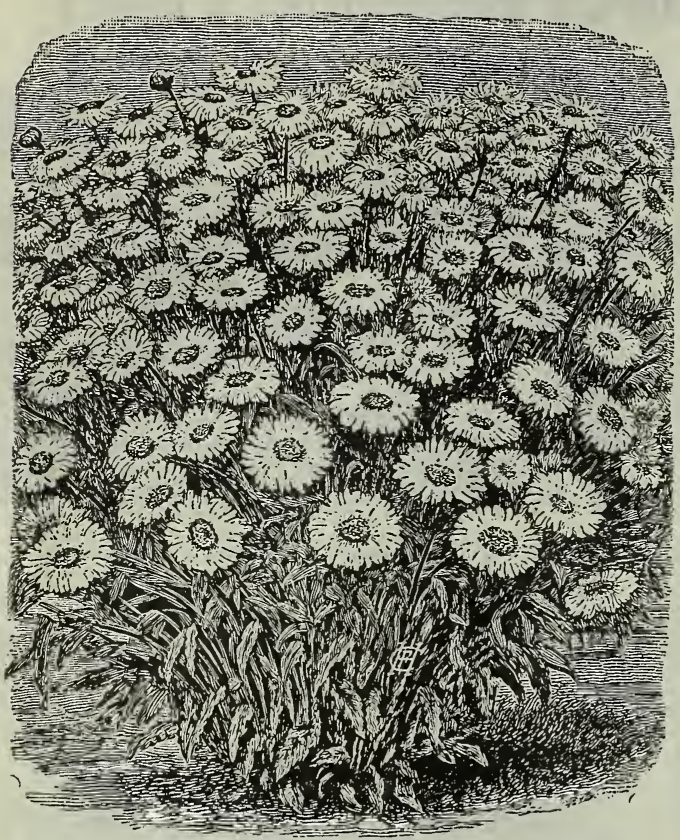

Chrysanthemum

\section{Campanulas (Bell Flower)}

PERSICIFOLIA GIGANTEA MOERHEIMI-This novelty is doubtless the best pure white Campanula hitherto introduced. The new form remains even more dwarf, not surpassing two feet in height, whereas its free flowering properties are truly wonderful, even the smallest spike being covered with large double flowers, suggesting Camellias. May to August. Price: Each, 25c.

MIEDIA (Canterbury Bells) - Well-known favorite flowers are of varied colors; July; two to three feet. Price: Each, 15c.

PYR AMIDAIIS-The most conspicuous of all Campanulas. Forming a perfect pyramid four to six feet high; crowded with large saucer-like flowers. Price: Each, 20c.

\section{Coreopsis}

GRANDIFLORA-Pretty border plant; 12 inches; yellow; June to September. Price: Each, 15c.

\section{Chrysanthemum (Hardy Pompon)}

One of the most popular of all perennials. They produce a lavish profusion of blooms, giving color, life and beauty to the garden just at a time when other plants have been killed by frost.

EAGLE d' OR-Finest golden yellow. Price: Each, 15c.

JULIA LAGRAVERE-Very rich garnet. P'rice: Each, 15c.

LUIA-Pure white. Price: Each, 15c.

RHODA-Delicate apple blossom pink. Price: Each 15c.

TRROJAN-Maroon with yellow center. Price:

\section{Shasty Daisy (Moonpenny Daisy)}

BURBANK'S IMPROVED-A decided improvement on the old Shasta Daisy; very free flowering; $4 \frac{1}{2}$ to 5 inches across; pure glistening white. Price: Each, 30c.

\section{Delphiniums (Hardy Larkspur)}

The hardy Larkspurs are one of the most important and most satisfactory plants in the herbaceous garden, and should be planted extensively even in the smallest garden. Their long spikes of flowers are produced continuously from June until late in the fall.

CHINENSIS-A pretty variety, growing only 18 inches high, with large open panicles of handsome flowers, varying in color through all the light shades of blue. Price: Each, 15c.

CHINENSIS ALBA-This beautiful white sort is unsurpassed and deserves a position in every garden; 2 feet. Price: Each, 15c.

FoRMosUM-Blooms from July to September. Large flower spikes, deep blue with white eye: three feet. Price: Each, 15c.

\section{Digitalis (Fox Glove)}

Old-fashioned perennial, throwing stalks four to six feet out of a mass of foliage, flowering profusely.

GLOXINIAEFLORA (Gloxinia flowered)-A strain of finely spotted varieties in white, purple, lilac and rose. Price: Each, 15c.

\section{Dianthus (Garden-Pink)}

BARBATUS-See sweet William.

DELTOIDES (Maiden Pink)-Pretty variety of medium-sized pink flowers, suitable for border or rockery planting. Price: Each, 15e.

COMET-Bright rosy crimson; a fine, large flower. Price: Each, 15c.

DELICATA-A soft, pure, pleasing, delicate rose. Price: Each, 15c.

WHITE RESERVE-A nicely fringed pure white. Price: Each, 15c.

\section{Funkia (Plantain or Day Lily)}

The Plantain Lilies are among the easlest plants to manage; their broad, massive foliage makes them attractive subjects for the border even when not in flower

COERULEA-Blue, broad green leaves. Price: Each, 15e.

SUBCORDATA-White fragrant flowers; pale green leaves. P'rice: Each, 20c.

\section{Ferns (Hardy)}

These plants thrive in most any partially shaded place. Require a loose, rich soil for successful growth.

MAIDENHAIR and six other varieties. Price: Fiach, 20e.

\section{Gillardia (Blanket Flower)]}

GRANDIFLORA-A showy and effective perennial. Flowers red, brown center, petals marked with rings of crimson and orange; two feet. Flowers from June to the end of season. Price: Each, 15e.

\section{It Pays to Plant the Best}




\section{PERENNIAL PLANTS-Continued Grasses orramentat)}

ARUNDO MACROPHYLLA GLAUCA (Giant Reed)-A remarkably strong growing variety, attaining a height of 15 feet, with foliage $311_{2}$ to 4 inches wide, much closer jointed than the type; the leaves are of a dark glossy green on the upper surface, and of a glaucous color underneath. Price: Each, 25c.

EULALIA JAPONICA VARIEGATA-A very ornamental variety; long, narrow leaves, striped green, white and often pink or yellow. Flower stalks from four to six feet. Price: Each, 25e.

ZEBRINA (Zebra Grass) - The long blades of this variety are marke 1 with broad yellow bands across the leaf. It makes a very attractive specimen plant for the lawn. Price: Each, 25e.

GYNERIUM ARGENTEUM (Pampas Grass)-One of the most effective. Its silvery plumes are produced on stems eight to ten feet high. Wellestablished plants can remain in the open ground if protected. Price: Each, 25e.

PHALARIS ARUNDINACEA VARIEGATA (Variegated Ribbon Grass, or Gardener's Garters) - Large, variegated foliage; an excellent grass for bordering large beds. Frice: Each, 10c.

\section{Gypsophila $\underset{\text { Breath) }}{(\mathbf{B a b y} \text { 's }}$}

The large graceful panacles of minute white flowers makes it indispensable in the border and vases.

PANICULATA-White; blooms August to september; two to three feet. Price: Each, 15e.

\section{Hollyhocks}

Few hardy plants combine as many good qualities as the Hollyhocks; the flowers form perfect rosettes of the most lovely shades and colors. A well-drained, rich soil will repay in quantity and beautiful flowers. A slight protection during the winter will be beneficial.

SINGLE VARIETIES-Mixed colors. Price: Each, 15e.

DOUBLE VARIETIES-Red, white, pink, yellow. Price: Each, 20c.

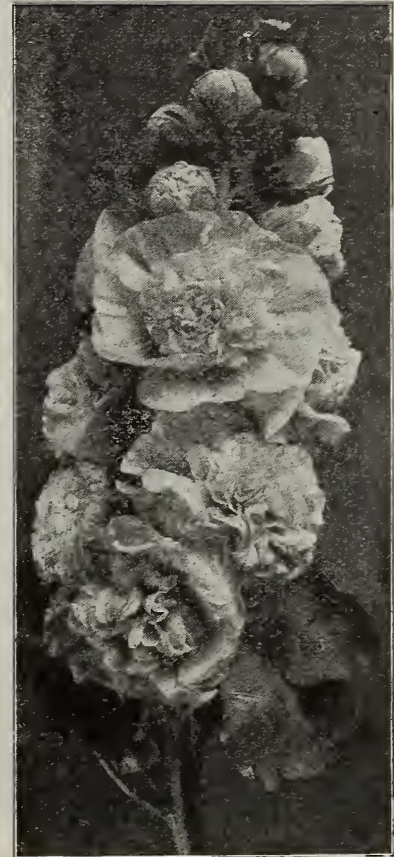

Hollyhocks

\section{Helianthus (sunflower)}

For extensive border planting and cutting, very desirable. Once planted will multiply rapidly.

MULTIFLORUS MAXIMUS - Produces immense single golden yellow flowers, 6 to 8 inches across; August to September; five to six feet. Price: Each, 15e.

-Fl-pl (Double Hardy Sunflower)-Large double Dahlia-like flowers. July to August; four to six feet. Price: Each, 15c.

MAXIMIULIANA-Proauces long graceful sprays after all other varieties have ceased flowering. Valuable for cutting, five to seven feet. Price: Each, 15e.

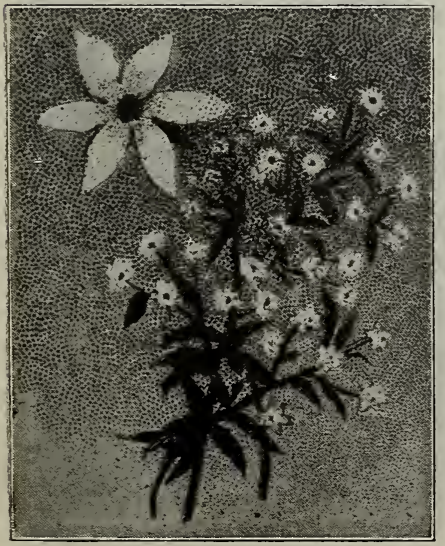

Gypsophila Each, 15e. Japanese. two feet. feet; June.

\section{Heliopsis sunflower)}

Similar in habit to Helianthus, flowering earlier of dwarfer habit; three feet.

PITCHERIANA-Flowers deep golden yellow, two inches across; blooms all summer. Price: Each, 15e.

\section{Hemerocallis $\begin{gathered}\text { (Yellow } \\ \text { Day Lily) }\end{gathered}$}

FLAVA-Erangrant yellow flowers produced in great profusion in July and August; three feet. Price: Each, 15c.

FULVA fl. pl.-Double orange; Day Lily; four feet. Price: Each, 20c.

\section{Hibiscus (Mallow)}

MOSCHEUTOS-Crimson eye; immense white flowers; crimson center; 24 inches in circumference; blooms all summer; four feet. Price:

\section{Iris Germanica-Fleur De Lis}

\author{
(German)
}

As the Japanese varieties, they are perfectly hardy, profuse bloomers; many shades"; thriving best in a dryer situation than the

EIGHT DISTINCT VARIETIES-As listed below. Price: Each,15e.

I. Bougere-Lilac and velvety purple; distinct, 18 inches.

I. Heetor-Light bronze, stained with purple. Fine.

I. Jacquesiano-Deep maroon velvet, tinged with bronze and crim. son; a rare and remarkable color; two feet; June.

I. L'Avenir-Lavender, a beautiful shade.

I. Lemon-White, spotted with purple and deep purple stripes; fine;

I. Louis Van Houtte-Salmon, tinged and striped with furple; two

I. Sappho-Clear blue and indigo; beautifully blended.

I. Silver King-Flowers silvery white, distinct and fine. 


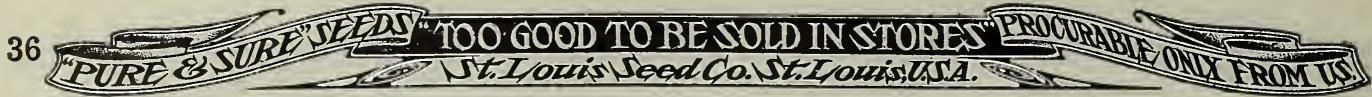

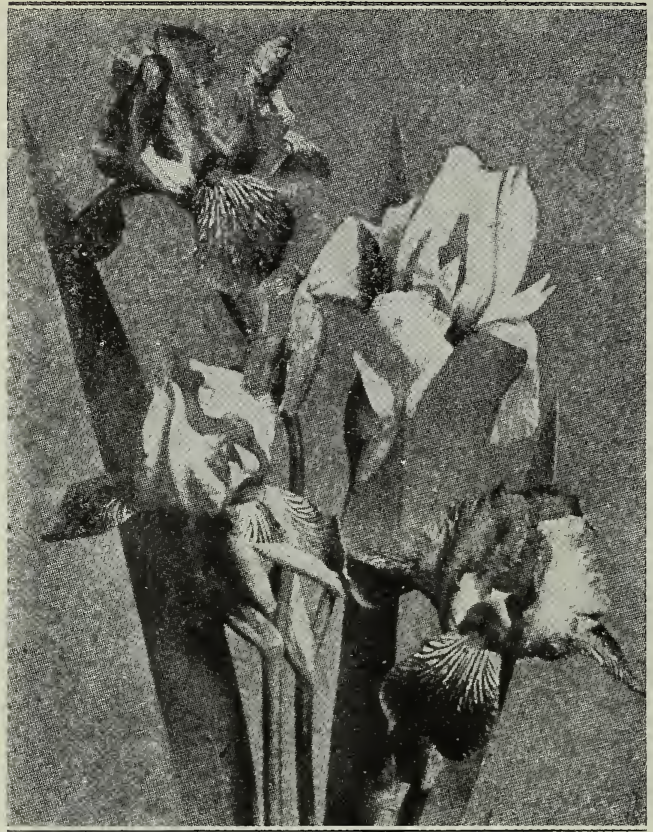

Iris

\section{Lysimachia}

NUMMULARIA (Creeping Jenny or Money-'Wort)-Valuable under trees and shrubs where grass will not grow. Spreads rapidly, making a dense carpet. Price: Each, 10c.

\section{Lily of the Valley}

A plant too well-known to need any further description. Indispensable for cut flowers. Price: doz. pips, 25c.

\section{Lychsris (Rose Campion)}

CHALCEDONICA Fl-pl.-Double flowering variety, producing immense heads of scarlet flowers, far exceeding in brilliancy the brightest Geraniums. July to September; 2-3 feet. Price: Each, 25c.

ALBA - White flowering form. Price: Each, 15c.

\section{Lobelias}

CARDINALS (Cardinal Flower)-Rich, fiery scarlet flowers; 24-36-inch spikes, each plant producing 10 to 18 spikes; July to September. Thrives in a moist situation. P'rice: Fach, 15c.

\section{Papaver (Poppy)}

VUDICAULE-(Iceland P'oppy) - Dwairf plant, fern-like leaves; borne in tufts; flowers on 1 foot stems; very pretty cup shaped in white, yellow, orange and scarlet. Price: Fach, 10c.

orientale (Oriental Poppy)-For a rich brilliant display of colors nothing equals them during the flowering period. Mixed colors. Price: Each, 25c.

\section{Primulas (Primrose)}

Perfectly hardy; indispensable for borders and rockeries; 1 foot. White, purple, blue; lilac. Price: Each, 10c.

\section{Pyrethrum}

Flowers similar to single asters. Very good for cutting; June; assorted colors. Price: each, 15c.

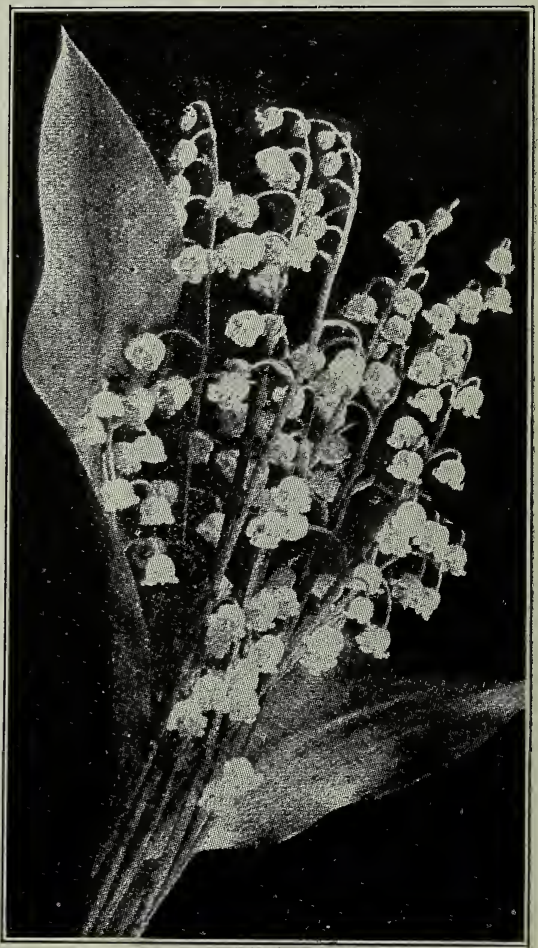

Lily of The Valley 


\section{PERENNIAL PLANTS-Continued Paeonies}

The old-fashioned Paeony is again coming into great favor; however, the types are so improved that one hardly recognizes these magnificent flowers; among the first to bloom in the spring.

\section{Standard Herbaceous Paeonies}

FESTIVA MAXIMA-Pure white, center of petals occasionally tipped red. Best white for cutting. Price: Each, 40c.

QUEEN VICTORIA-Large white, creamy center. Price: Each, 25e.

LOUIS VAN HOUTE-Large, loosely shaped flower; brilliant crimson. Price: Each, 30c.

GOLDEN HARVEST-Outer petals blush, center petals crimson striped, giving a creamy pink appearance. Price: Each, 40c.

HUMEA CARNEA-Strong grower, cherry pink; fine cut flower variety. Price. Each, 35c.

\section{Officinalis}

This is the old-fashioned Paeony; flowering ten davs earlier than the above.

RUBRA-Red. Price: Fach, 25c.

ROSEA-Rose. Price: Each, 25e.

ALBA-White. Price: Each, 25e.

MIXED-Double; white, red and pink. Price: Each, 10e; large size, 25e each; mammoth, 50e each.

\section{Phlox}

DECUSSATA (R. P. Struthers)-Bright rosy carmine: claret red eye. Price: Each, 15e.

BRIDESMAID-Pure white with crimson eye. Price: Each, 15e

JEANNE D'ARC-Pure white; late. Price: Each, 15c. VON GOETHE-Clear pink, white eye. Price: Each, 15e.

SFLMA-Pale rose, red eye. Price: Each, 15c.

F. G. VON LASSBURG-Magnificent white. Price: Each, 25e.

\section{Rudebeckia}

\section{(Cone Flower)}

GOLDEN GLOW-A very robust grower; five to six inches. Produces masses of rich golden yellow flowers, Price: Each, 15c.

MAXIMA-Large glaucous green leaves, bright yelluw flowers; five to six inches across with a cone two inches high. June to September. Price: Each, 25c.

\section{Stokesia}

(Corn Flower or Stokes Aster)

CYANEA-Bears handsome lavender-blue flowers from July to October, measuring from four to five inches acrosis. Ons of the most desirable border plants; 18 to 24 inches high. Price: Each, 15e.

CYANEA ALBA-Identical with the above in habit. Flowers white. Frice: Each, 20c.

\section{Veronica}

SPICATA-Desirable border plant, producing long spikes of bright blue flowers. Price: Each, 15e.

SPICATA ALBA-White form of the above. Price: Each, 15e.

\section{Yucca (Adam's}

FILAMENTOSA-This plant can be classed at the head of the herbaceous perennials. Price: Each, 25e.

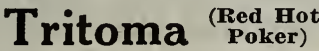

PFITzERI-Ever blooming Flame Flower. Flowers in spikes three to four feet high of a rich orange scarlet; August to November. P'rice: Each, 15e.

TRIUMPY-Rapid growing variety, flower heads 12 to 16 inches long on stems 4 to 5 feet high, distinct rich saffron yellow color; August to October. Price: Flach, 15e.

\section{Violets}

These hardy varieties will give-satisfaction, blooming profusely in the early spring. SWEET VIOLETS-Large double, deep purple, delightfully fragrant.

Price: Each, 10c.

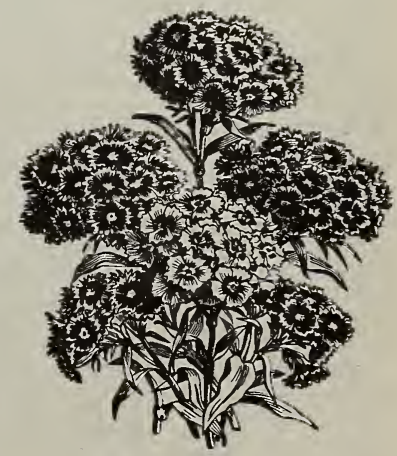

Sweet William 


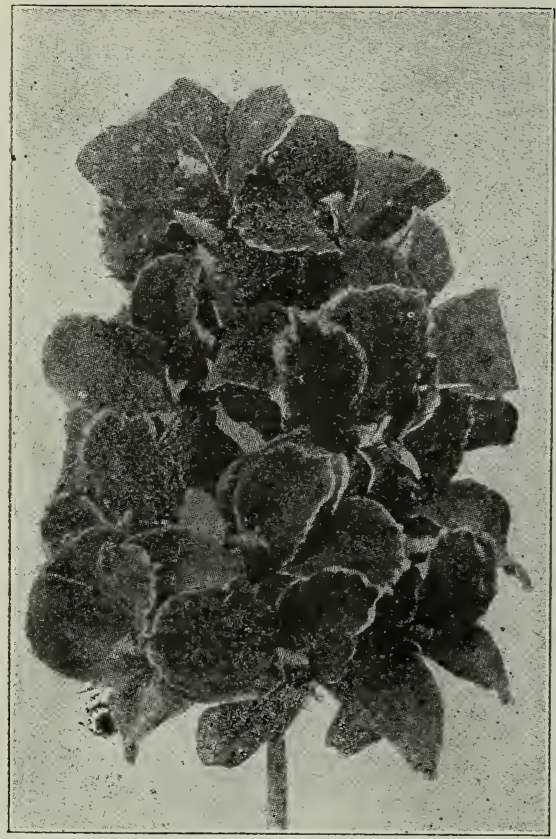

Canna (Queen Charlotte)

\section{Summer Flowering Bulbs Amaryllis}

The Amaryllis is pre-eminently a window garden plant for the amateur, producing under the simplest conditions one, two or even three spikes, two feet or more high, which are crowned with from three to six large and gorgeous trumpet-shaped blooms, which last long in good condition.

NEHRLING'S FLORIDA HYBRIDS-The result of 20 years' labor in fertilizing and cross-fertilizing on part of our most foremost Amaryllis grower. Flowers from 4 to 6 inches across', perfectly circular in, outline and of varied colors. varying from deep crimson) to dazzling orange scarlet. Price: Each, 50c.

FORMOSISSIMA (Jacobaean Lily)-Crimson, blooming early in summer. Price: Each, 10c.

JOHNSONII-Large flower, rich crimson scarlet; striped white. Price: Each, 25e.

\section{Cannas}

Our catalogue of Cannas on these pages are varieties of the highest s'tandard from afl sources in the world. We flower them on our own grounds and know them to be true. They are now recognized as the prettiest and showiest of all bedding plants.

CHARLES HENDERSON-Deep crimson, yellow flame at the throat.

FLORENCE VAUGHAN-Deep yellow, mottled rich crimson.

MADAME CROZY - A brilliant vermillion-scarlet, bordered yellow.

QUEEN CHARLOTTE-A grand, large flowered, everblooming French Canna, beautiful scarlet, bordered with yellow.

BEAUTE POITEVINE-A very fine dark crimson variety with dark metallic green foliage and deep, rich crimson flowers.
ITALIA-The new Giant Orchid-Flowered Canna. The coloring is golden-yellow, with great patches of brilliant reddish crimson.

Prices on all above varieties, dormant roots. Each, 10e; per doz., \$1.00.

Potted plants of same, April 15th: Each, 15c; per doz., \$1.50.

\section{New Giant Cannas}

PENNSYLVANIA-The flowers are often 7 to 8 inches across, with petals $2 \frac{1}{2}$ inches broad. Produces double the number of flowers of any Giantflowering Canna previously introduced. Height, 6 feet. Splendid habit and foliage. Dormant roots, 10e each; $\$ 1.00$ per doz. Potted plants, April 15th, 15e each; \$1.50 per doz.

AUSTRIA-The New Giant Golden Lily-Flowered Canna. Grows over 6 feet high, surmounted with glorious golden, lily-like flowers. Dormant roots, 10c each; \$1.00 per doz, Potted plants, April 15th, 15e each; \$1.50 per doz.

IKING HUMBERT-The highest type of the Orchid-flowered sorts, with bronze foliage, flowers brilliant orange, scarlet with bright red markings, 6 to 8 inches across; height, 6 to 8 feet. Dormant roots, $15 \mathrm{c}$ each; \$1.50 per doz. Potted plants, April 15th, 20e each; \$2.00 pes doz.

FRAU MARIE NAGEL-A grand new dwarf white Canna. The very large flowers are of cream color when first open, turning to pure white, after being fully open for 15 minutes. Dormanit roots, 15e each; \$1.50 per doz. Potted plants, April 15th, 20e each; \$2.00 per doz.

BLACK BEAUTY-It is undoubtedly the finest dark-leaved Canna in existence. The broad, tropical foliage is of the deepest crimson bronze. It is a splendid, hardy grower. Dormant roots, 15c, each; \$1.50 per doz. Potted plants, April 15 th, 20c each; \$2.00 per doz.

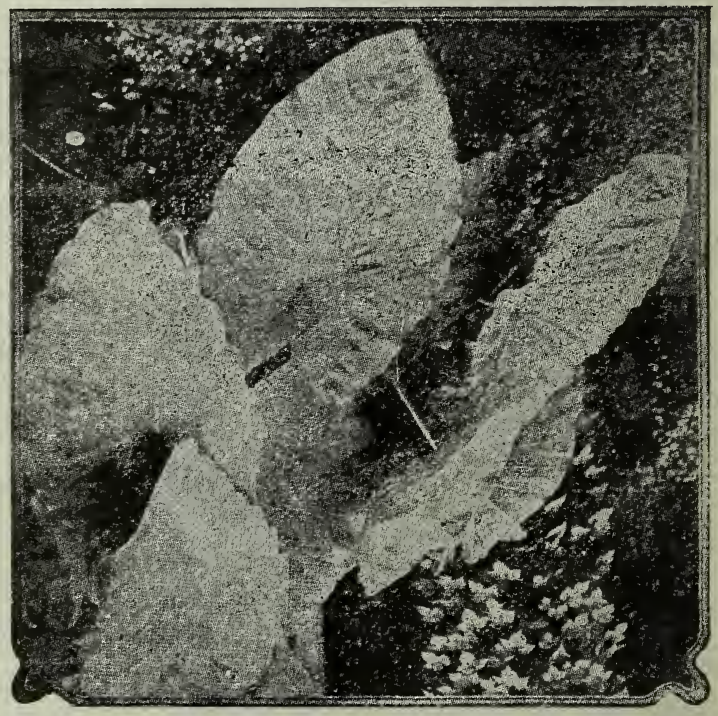

\section{Caladium (Elephant Ears)}

ESCULENTUM-A handsome plant of tropical aspect, bearing leaves sometimes a yard or more in expanse. Effective as a single plant on a lawn, or in groups; also useful for decorative effect near streams or ponds. Price: Small size, 15e; medium, 25e; large, 50e; mammoth, 75e: 50c. 


\section{SUMMER FLOWERING BULBS-Continued Gladiolus}

AMERICA-Conceded the best variety for cutting or bedding purposes. Orchid-like flowers' of a delicate pink color. Price: Each, 10c; per doz., \$1.00.

AUGUSTA-A magnificent white variety. Price: Each, 5c; per doz., 50e per 100 ,\$3.50.

BRENCHLEYENSIS-The best scarlet for massing. Price: Per doz., 25e; per 100 , \$1.75.

IRS. BEECHER-Brilliant crimson scarlet, white throat. Price: Each, 10e; per doz., 75e; per 100 , \$5.00.

GROFF'S HYBRIDS (Gold Medal Strain) - This strain has a worldwide reputation. All colors mixed. Price: Per doz., 50e; per 100 , $\$ 3.50$.

GANDAVENSIS-A beautiful crimson and yellow type. Price: Per doz., 25c; per 100, \$1.75.

BLANCHE-Snow white, of giant type, with soft rose tintings; a beautiful variety. Price: Each, 10c; per doz., \$1.00.

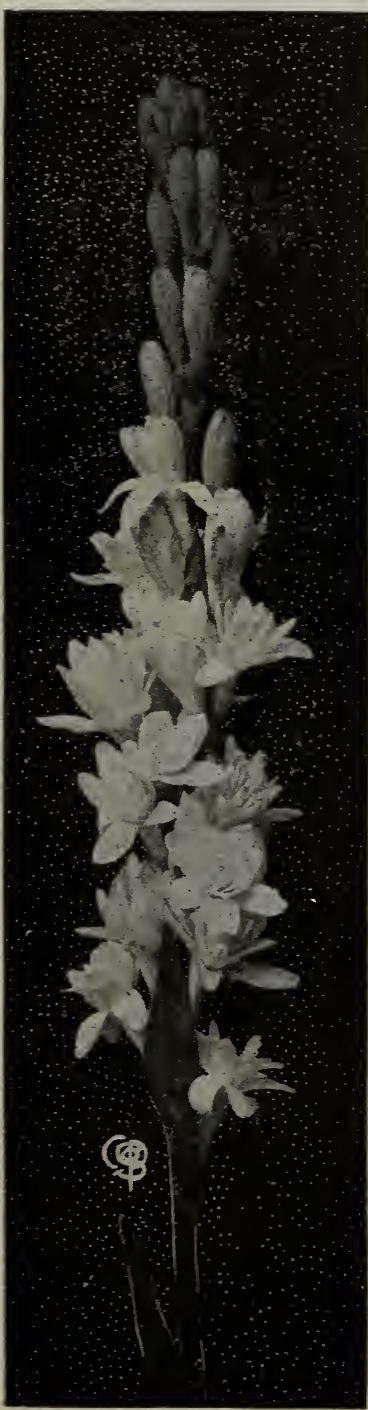

\section{Tuberoses}

One of the most delightfully fragrant and beautiful of the summerflowering bulls. By skillful management a succession of flowers may be obtained all the year round. For early flowers they can be started in February or March in the green-house or hotbed; and for a succession they can be planted at intervals as late as July. For flowering in the open border, plant about the middle of May, or as soon

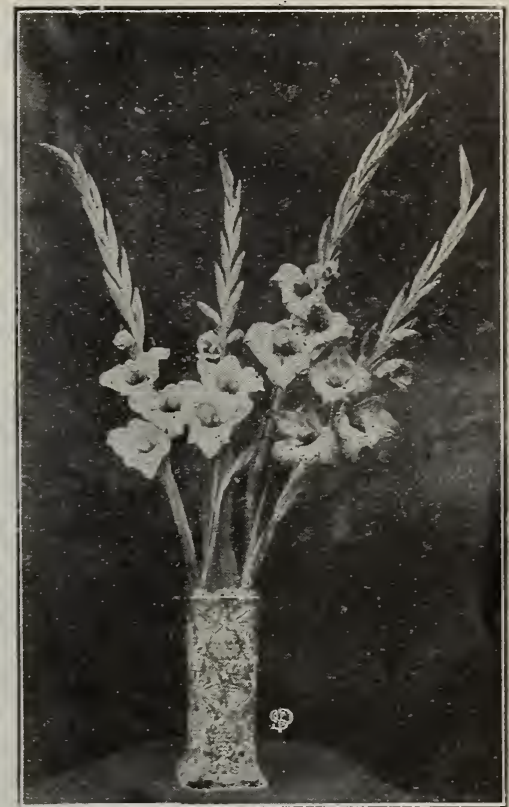
as the ground becomes warm.

EXCELSIOR DOUBLE PEARL-(See cut)-Price: Extra large bulbs, 3 for 10e; per doz., 25e; per 100,\$1.50.

ARMSTRONG'S EVERBLOOMING-This variety blooms year after year and produces single pure white flowers of a fragrance similar to that of the "Jasmine." It makes a splendid cut flower and should be in everyone's garden. Price: 3 for 10c; per doz., 25e; per 100 , \$1.50.

\section{Lilies (Japan)}

All herbaceous borders should have a few Lilies scattered through them. The sorts offered below can be planted with excellent results during the spring months. It is in the hardy border that Lilies do best, as they get the benefit of the shade of the surrounding plants, which is so necessary for their welfare; other varieties should be planted in the autumn and are offered in our autumn catalogue.

A U R A T U M (Gold-Banded Lily)-Large, graceful flowers, composed of six petals of a delicate ivory-white, thickly studded with chocolate crimson spots, and striped through the center a golden yellow. Price: Each, 15c; per doz., $\$ 1.50$.

SPECIOSUM ALBUM-Large white flowers of great substance, with a greenish band running through the center of each petal. Price: Each, 15c; per doz., \$1.50.

SPECIOSUMI RUBRUM, OR ROSEUM - White, he avily spotted with rich, rosy, crimson spots. Price: Each, 15e; per doz., \$1.50.

T I G R I N U M SPLENDENS (Tiger Lily) - Very large flowers; orange, spotted black. Price: Each, 10c; per doz, $\$ 1.00$.

TIGRINUM Fl. Pl. (Double Tiger Lily)-A double flowering form of the above. Price: Each, 15c; per doz., \$1.s0.

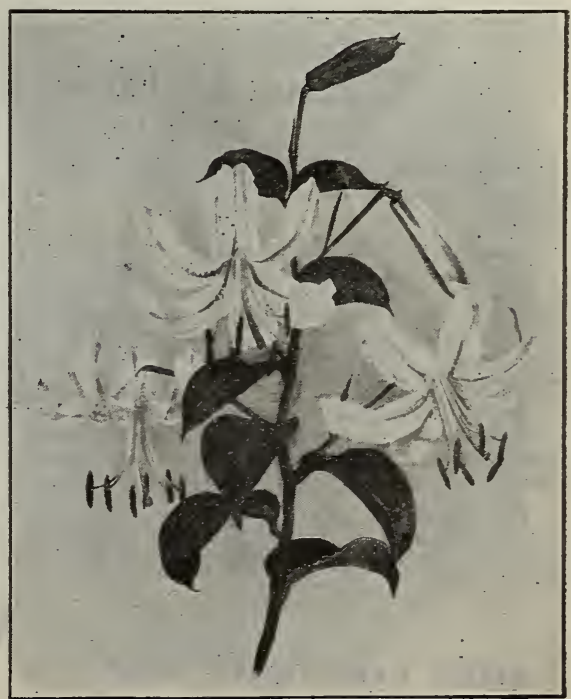




\section{Fancy and Show Dahlias Double}

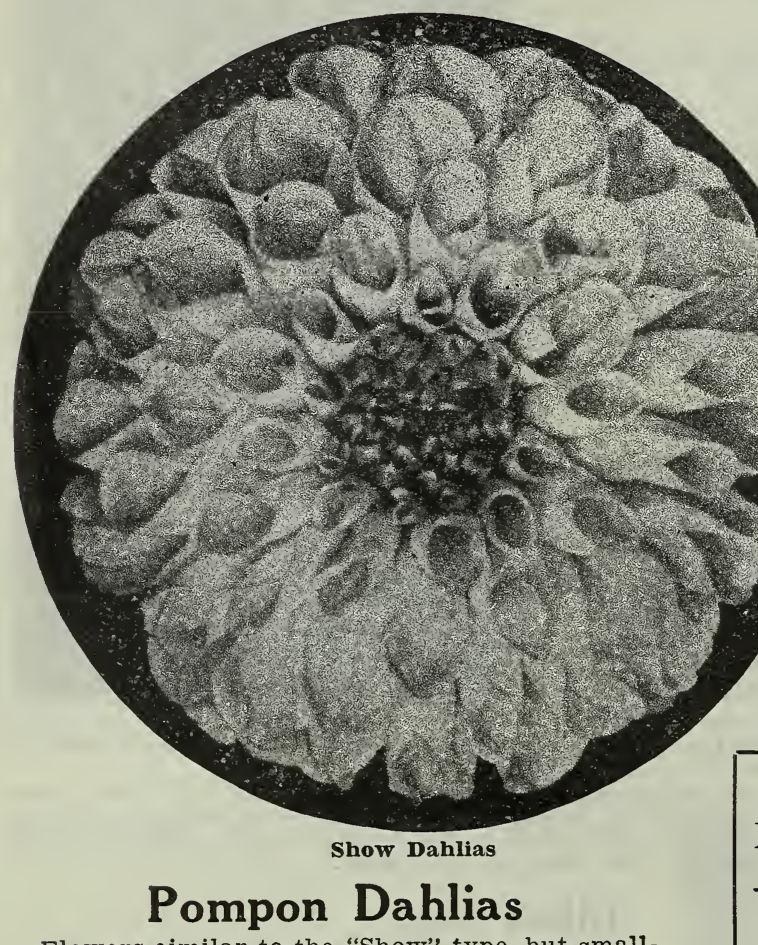

These varieties cannot be surpassed for size and beauty. They are very large and double, being full to the center.

RED IUSSAR-Pure cardinal red. Price: Each 15e.

GRAND DUKE ALEXIS-A magnificent flower of largest size and distinctly unique form, as the petals are rolled up so that the edges overlap each other. The color is pure white, distinctly tinged delicate pink. Price: Wach 15c.

TWENTIETH CENTURY-Early in the season, an intense rosy-crimson, shading gradually to almost white on the edges and a light halo around the disc. As the season advances the flowers become lighter, changing to almost pure white, suffused with soft pink. Price: Each 20c.

RUBY QUEEN-Brilliant deep ruby purple; an elegant dark variety. Price: Each 20e.

APPLE BLOSSOM-Combining all the delicate shades of the apple blossom. Price: Each 15c.

Beautiful Yards Need Flowers to Make them Complete. : : : : :

Flowers similar to the "Show" type, but smaller flowers produced in greater profusion.

SNOWCLAD-Finest white Pompon to date. Price: Each 15c.

SUNSHINE. Brilliant scarlet. Fine form, full center, long stems; largely used for cutting. Price: Each 15c.

\section{Cactus Dahlias}

The Cactus type is without a doubt the most popular variety for cut flower purposes. Flowers borne on long stems and are of a beautiful quilled form giving them a loose, fluffy appearance.

KRIEMHILDE-The color is a fresh, delicate pink shading to a deep rose-pink. The flowers, after being cut a short time, develop white petals at the center, giving it a beautiful pink and white contrast, producing flowers in abundance on long, stiff stems, which makes it an ideal variety for cut-flower purposes. Price: Each 15c.

NYMPHAEA-The most delicately beautiful of the entire collection. Color clear, light shrimppink, tinting lighter toward the center. P'rice: Each 20c.

FLORA-An ideal white Cactus Dahlia. A large, heavy flower, produced on stout, stiff stems, makes it valuable for cutting. Price: Each 25c.

\section{Mixed Dahlias}

MIXED DAHLIAS-All colors mixed. Price: each 10c; dozen $\$ 1.00$ 


\section{FLOWER SEED NOVELTIES}

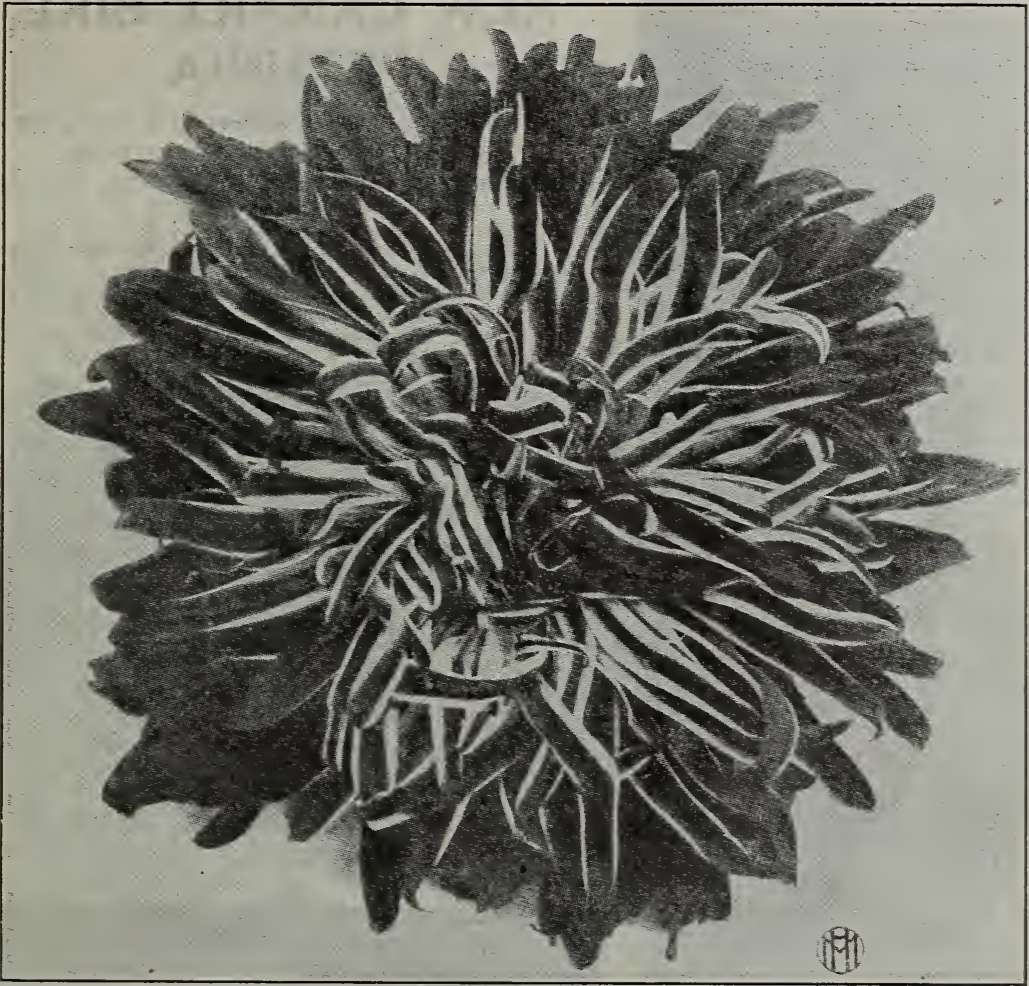

St. L. S. Co.'s New Novelty Aster Mixture

This superb mixture is composed of all new novelties of recent introduction. We know of no mixture of asters that will equal this for cutting and bedding purposes. The various shades' are mixed in equal proportion and most desirable effects obtained by planting these. We have no hesitarcy in recommending this mixture to the most critical. Blooms exhibited from this mixture scored highest awards wherever they were shown (hh. A). Price: Pkt. 15c; oz. $\$ 2.00$.

\section{Giant Comet Aster}

One of the most beautiful varieties of Asters closely resembling the large-flowering Japanese ichrysanthemum. Flowers grow from 3 to 5 inches in diameter and to a height of about 18 inches. We can furnish the following colors: White, light blue, deep blue, rose, crimson and white passing to rose; mixed. Price. Plit. 10e;

New Novelty Mixture Asters. 1 oz., \$1.50.

\section{PANSIES}

This GRAND, LARGEST Flowering Variety of Gorgeous Colorings cannot be surpassed.

\section{St. L. S. Co.'s New Exhibition}

This wonderful Giant Pansy we offer as our leacer. We challenge its equal from any seeo house, grower or originator. We know it is impossible to procure a plant anywhere near its equal in any respect. You will never have known the pleasure of flower-growing until after you have tried this splendid new offering. We control the entire stock of this new wonder, which is produced for us under the skilled eye of Europe's' most successful Pansy specialist. The colorings of this new Pansy are mixed, there being no end to the numerous shades which nature has endowed upon this gigantic marvel, every petal being a veritable display of shades and coloring in itself. Price: Pkt. 25c.

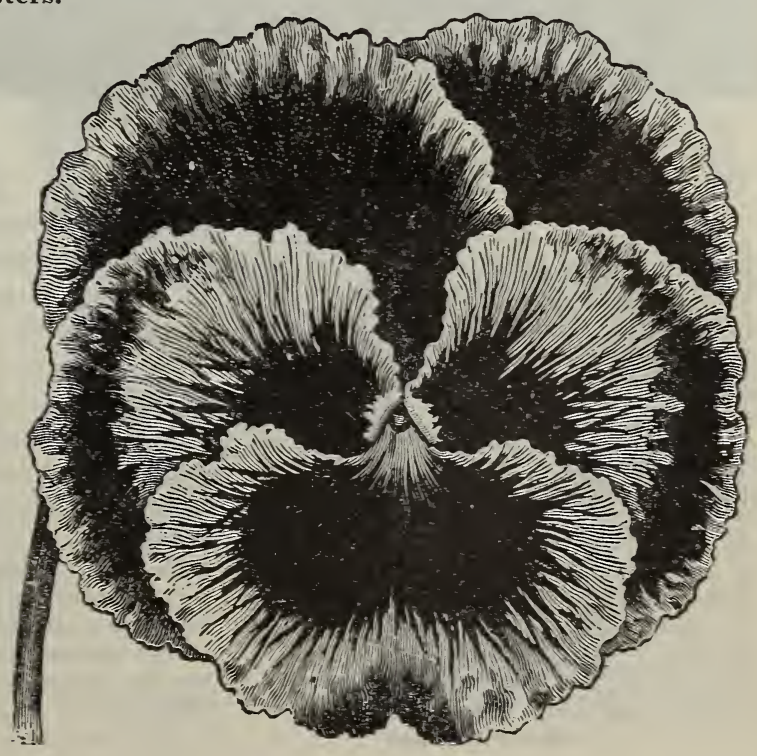




\section{Flower Seed Novelties}

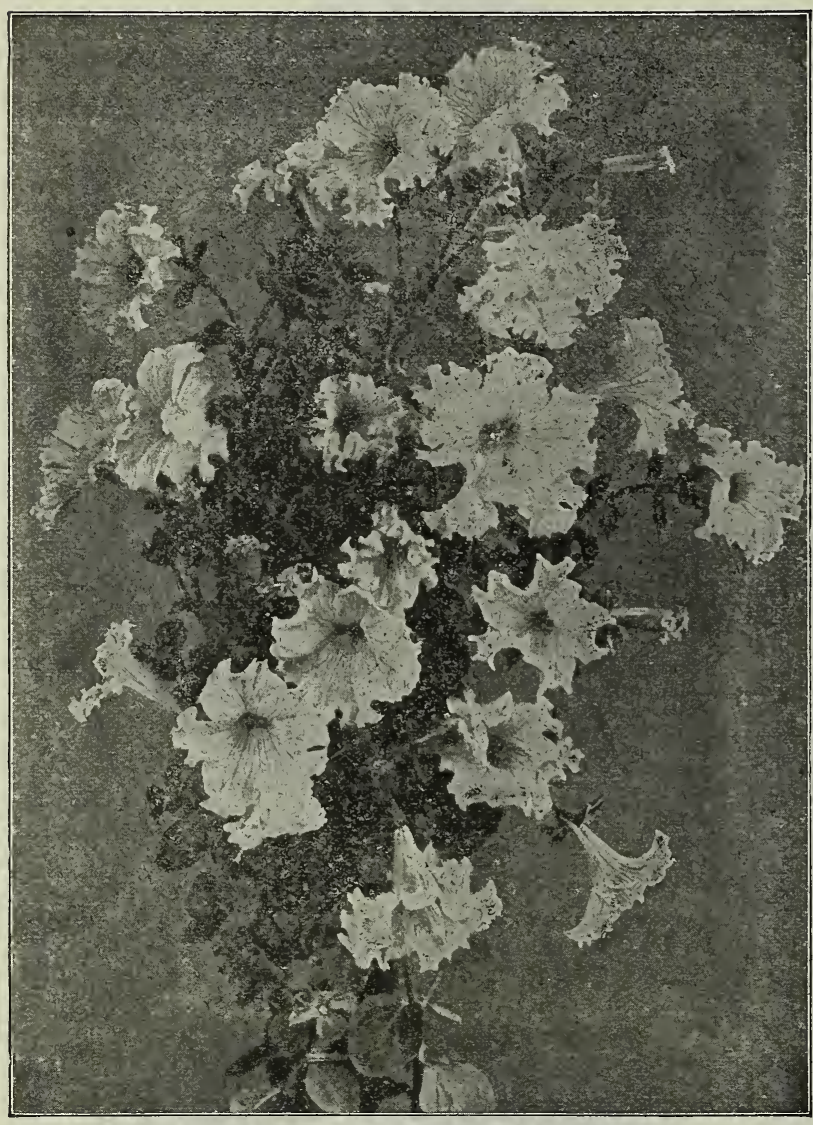

St. L. S. Co.'s New Canary Bird Petunia

\section{Admiral Poppy}

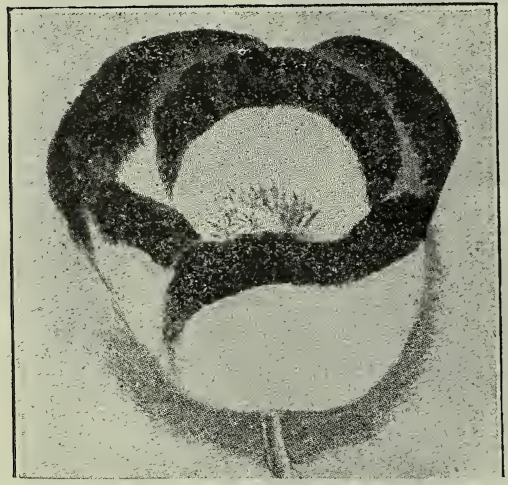

"Admiral" Poppy
A single Paeony-flowered variety of surpassing beauty, having large, smoothedged flowers of glistenting white, with a broad band of brilliant scarlet around the top. These two colors form a very striking contrast, and when planted in groups produce a magnificent effect. Price: Pkt. 10c.

\section{NEW CANARY BIRD PETUNIA}

The Greatest, the Grandest and Most Gorgeous Petunia Ever Discovered.

THE FIRST YELLOW PETUNIA EVER OFFERED.

Petunia lovers' desires have at last been granted. We now offer you for the first time in existence a beautiful Canary Yellow Petunia. The plant grows to a height of about 14 inches, and is of the mos't compact growth. The flowers are of medium size with finely fringed and curled borders. The press and public are now going wild over this new species. Florists demands have become so great that it will be years before the trade can be fully supplied. If you are looking for a flower of the most exquisite beauty, you need look no further. Our new "Canary Bird" Petunia will please and surprise you beyond doubt. Price: Pkt. 30c.

\section{Sunflower "Starlight"}

(Our own raising.) In this new variety of Annual Single Sunflower we have a fine advarice. The flowers are large, of very graceful appearance, and with petals beau. tifully twisted like a firie form of Single Cactus Dahlia.

The color of the flowers is a beautifui canary yellow, and borne on long stems, cannot be excelled for cutting purposes Priçe: Pkt. 15e.

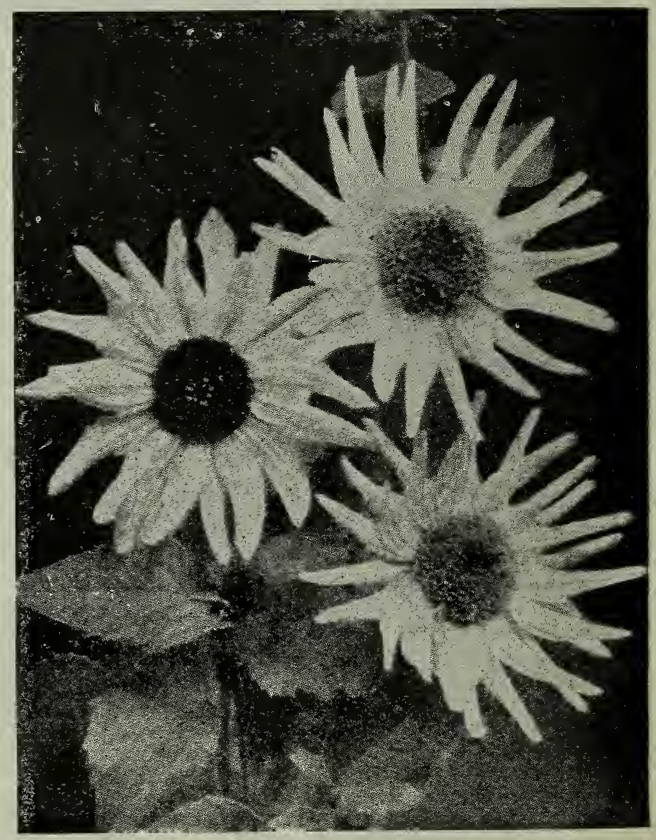

"Starlight"$$
\text { "Starlight" }
$$ 


\section{Flower Novelties

Salvia Splendens

A Beautiful and Gorgeous Effect when in Full Bloom.

A nuch improved strain of the Salvia Splendens Bonfire. It forms a globular, strong branching bush of from 15 to 18 inches' high. Its long, strong, shining scarlet blood red panicles are borne erectly and freely above the luxuriant dark green foliage ana are produced in such a quantits that the plants' fully developed, are entirely covere with them and nothing to be seen of the: foliage. Price: Pkt. 15e.

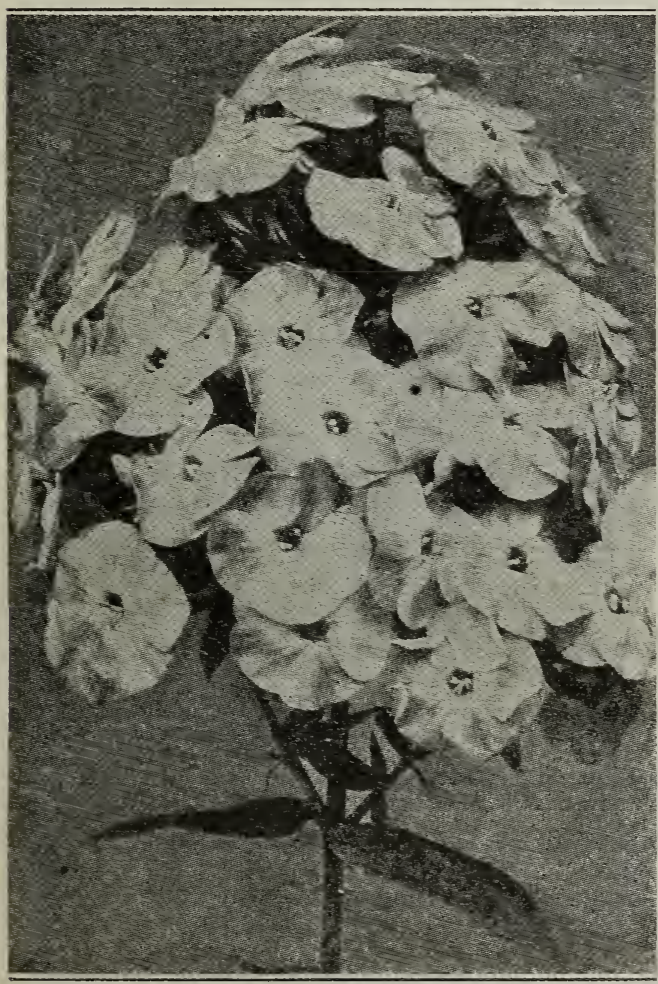

Large Flowered Phlox

\section{Verbena}

ST. L. S. CO.'S MAMMOTH STRAIN

The individual blossoms are frequently larger than a silver quarter; in fact, many are scarcely covered by a silver half dollar. Ours is a strain of truly Mammoth Verbena that produces uniformly magnificent trusses of flowers which embrace a wide range of colors. MAYMOTH WHITE 10c: MAMMOTH PURPLE 10c; MAMMOTH SCARLET 10c.

All colors mixed, pkt., 10c. $1 / 4$ oz. 50c.

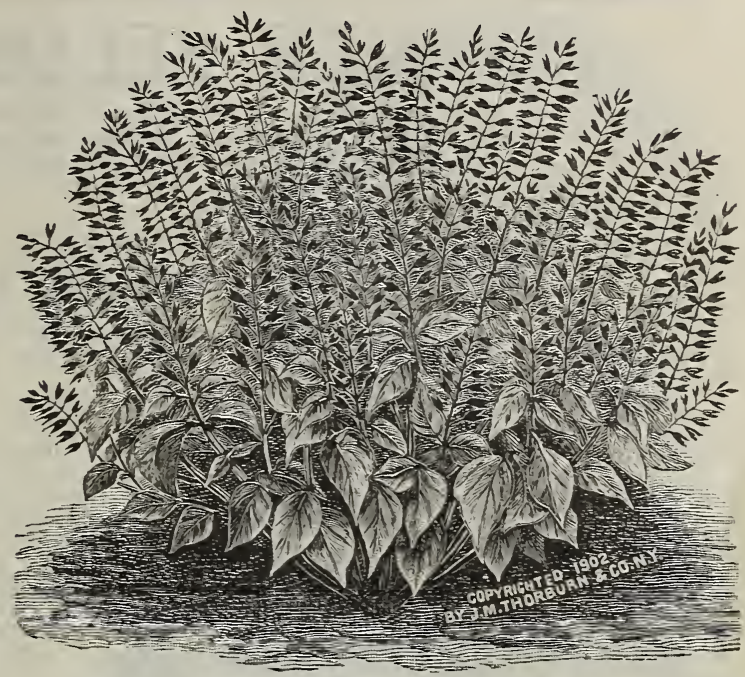

Salvia Splendens "FIREBALL"

\section{Phlox}

A grand flower for giving solid color effect. The flowers literally. cover the beds with their brilliant hues. It is a wonderful bloomer and continues late in this seasor if not allowed to produce seed.

LARGI: FLOWERING-This important strain is not only notable for variety and brilliancy of colors, but also fol the perfection and size of flowers, which are very lare and round, the petals overlapping each other. Mixed. Price: Pkt. 10c; oz. 50c.

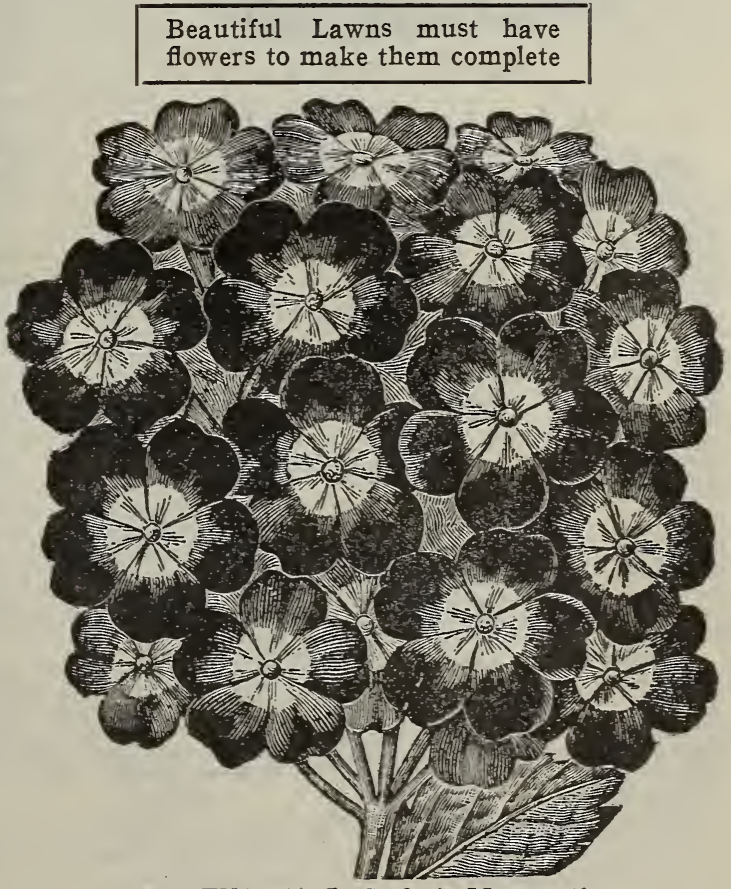

VERBENA-St. L. S. Co.'s Mammoth 


\section{FLOWER SEEDS - General List}

The following abbreviations and designations will be of material aid in making selections:

1 designates early-blooming in spring and $\epsilon$ arly sumnier.

2 designates intermediate-blooming in midsummer.

3 designate late-blooming in late summer and autumn.

A represents Annual-lasting but one year.

$B$ represents Biennial-lasting two years.

S represents shrubs-plants of bushy habit.

$P$ represents Perennial-lasting three or more years. Bu represents bulbous plants.

I represents Evergreen-retaining foliage the entire year.

As a large number of Biennials and Perennials, if sown early, flower the first season, this distinguishing mark $(\dagger)$ is affixed to such.

The hardiness is denoted by the following abbreviations, but it should be understood that this is intended to apply to the climate of the Middle States. Further north or south these designations apply only in a comparative way:

$h$ represents hardy-plants for open border.

hh represents half-hardy-plants that require to be forwarded in pots or frames.

$t$ represents tender-requiring protection.

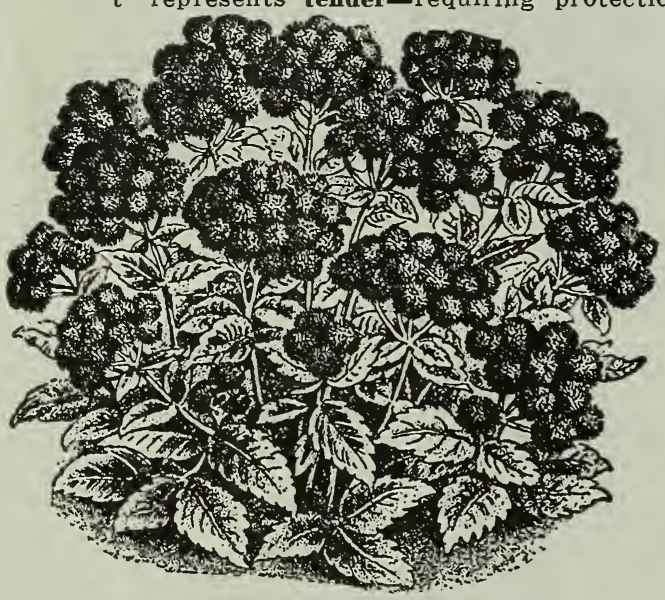

Ageratum Mexican

\section{Adonis Aestivalis}

(Pheasant's Eye.)

Beautiful dark scarlet flowers with light center. Of easy culture and showy. Fine cut foliage. A very pretty plant, $2-3$ h. A.; 1 foot. Price: Pkt., 5c.

\section{Acacia}

A beautiful shrub with graceful branches, bearing racemes of fragrant yellow flowers. Soak seeds in hot water. 1; g. P.; 6 foot. P'rice: Pkt., 10c.

\section{Alyssum}

This is one of the finest hardy annuals we have, and is beloved by many on account of its modest blossoms, very similar to white forget-me-nots. It is pleasantly fragrant, and just the thing for personal adornment or the breakfast table. It begins to blossom early in the season and blooms more or less constantly until fall.

CARPET OF SNOW-We know of no other white flower which is so particularly well adapted to borders, ribbons, etc., as our Carpet of Snow Alyssum. The plants commence to bloom when quite small, and will flower all summer long till late in the fall. This habit, with its fragrance, makes it indispensable. h. A. Price: Pkt., 5c; 1/2 oz., 20c.

IIT'TLE GEM-The best variety for bedding. Very dwarf and compact. Price: Pkt., 5e; 1 oz., 20c.

MARITIMUM-Not compact like Little Gem. Price: Pkt., 5e; oz., 20e.

\section{Abutilon}

(Flowering Maple.)

A very ornamental pot plant. Handsome little bushes, covered with bell shaped flowers in the daintiest and also strongest colors, dotted and veined. Bloom readily from seed the first summer, $2-3 ;$ g. S; 4 ft.; Hybrids Mixed. Price: P'kt., 15c.

\section{Abronia Umbellata}

\section{(Sand Verbena.)}

Verbena-like, rose-colored flowers. Elegant trailng habit. $2 ;$ h, A. Pkt. 5c.

\section{Ageratum}

(Floss Flower.)

One of the best bedding plants in white and blue colors. Blooms all summer long. It is one of the few good bedders whose flowers do not fade or become spoiled by rain, sun or drouth. It often keeps up a good appearance longer than geraniums. h. A.

BLUE STAR-A handsome new variety, different from all other Tom Thumb sorts. The tiny bushy plants do not exceed 4 or 5 inches in height, with clusters of flowers of light blue, with dark red center, changing to pure light blue. The plants are literally covered with flowers; we have counted over 200 on a single plant. Price: Pkt., 10c.

IMPERIAL DWARF BLUE-Good plant for ribbon borders; 6 in. Price: Pkt., 5c; 1 oz., 40c.

IMPERIAI DWARF WHITE-Like above, except in color. Price: P'kt., 5c; 1 oz., 40c.

LITTLE DORRIT-Azure blue, splendid coloring, 6 inches high, 1 foot across. Price: Pkt., 5c; 1 oz., 40c.

MEXICAN MIXED-Blue and white, good for cuting; 18 in. Price: Pkt., 5c; 1 oz., 25c.

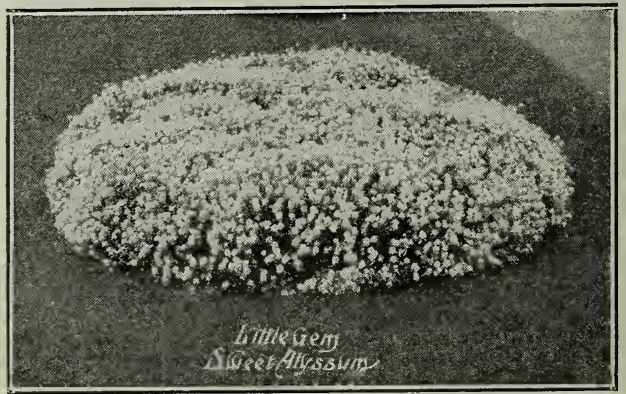




\section{Arabis (Rock cress)}

ALPINA NANA COMPACTA-One of the first flowers to bloom in the spring. Pure white, low, compact, carpet-like growth, useful for rockeries and the edge of a bed of perennials. For covering graves is unexcelled. 1 to $3 \mathrm{H}$. P. Price Pkt., 10e; $1 / 2$ oz., 50e.

\section{Amarantus}

Beautifully colored foliage plants; succeds best in sunny, dry locations.

TRI-COLOR (Joseph's Coat)-Makes a very pretty effect when used the same as Coleus. Keep it cut back to produce a symmetrical plant for edging; red, yellow and green; 2-3; t. A. 3 feet. Price: Pkt., 5e; 1 oz., 35e.

CHOICE MIXED-Price: Pkt., 5e; 1 o.z., 20c.

\section{Asparagus}

PLUMosUs-Probably the most popular house plant today. We sell thousands to florists who grow the pot plants. You can grow it for yourselves and neighbors. The leaves are bright green, gracefully arched, surpassing Maidenhair Ferns in grace, delicacy of texture and richness of color. Price: Pkt., 10c.

SPRENGERI-Similar to Plumosus in coloring, only hardier and more easily grown; 1 g. P. Price: Pkt., 10c.

\section{Arctotis Grandis}

\section{(Blue-Eyed Daisy)}

Its flowerheads, borne on long stems, the ray florets, being pure white on the upper surface, are embellished by a narrow yellow zone at their base; reverse of petals pale lilac; $2 ; \mathrm{h}$. A Price: Pkt., 5e.

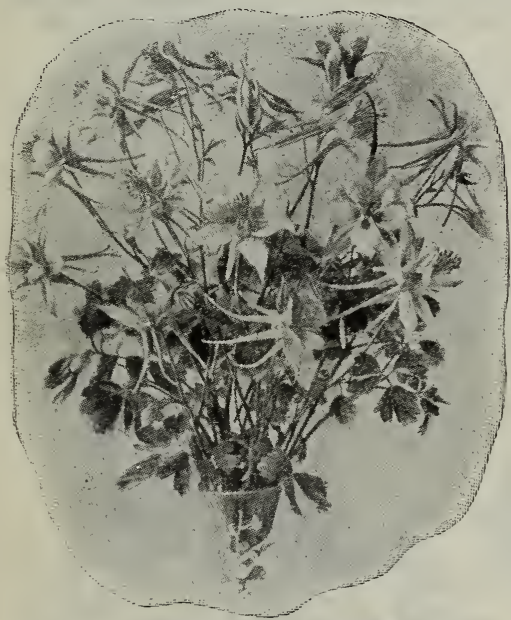

Glandulosa Aquilegia

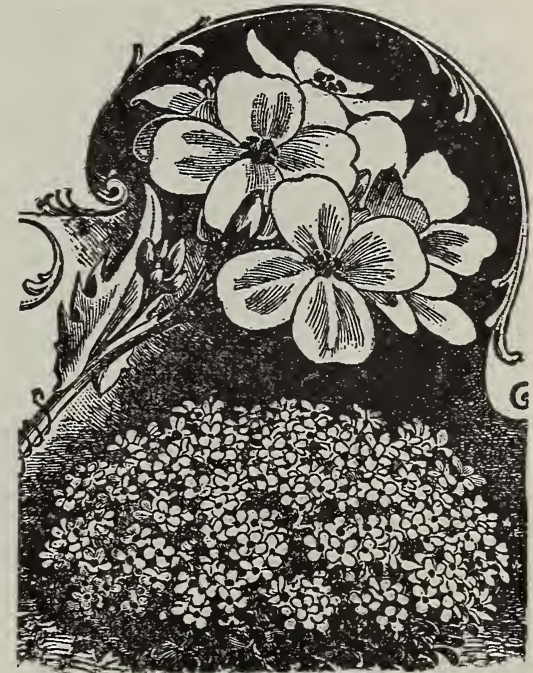

Arabis (Rock Cress)

\section{Aquilegia (Columbine)}

Charming hardy perennials, bearing in countless number through May and June their exquisite blossoms of clear blue white, rose yellow, purple, striped ( $2 \mathrm{ft}$.$) . For planting in per-$ manent places, $h$. R.

NEW GLANDULOSA-The flowers of this new strain are greatly enlarged, and the range of colors of the flower is of a most delicate blue, the Corolla being pure white Luxuriating in the more moist situations in the garden, growing from 1 to $11 / 2$ feet high. The large, unique, long-spurred flowers gracefully hang on long stems, are not only brilliantly effective on the plant, but equally as desirable when cut for vase and house decorations. Price: Pkt., 10e.

DOUBLE MIXED-Price: Pkt., 10c.

\section{It Pays to \\ Plant the B E S T ::}

\section{Antirrhinum}

(Snapdragon)

They are easily raised from seeds in any rich, sunny bed Spring seedlings bloom by midsummer, and if the flowers are cut freely the flowering will be continuous till fall.

QUEEN VICTORIA-The plants ( $3 \mathrm{ft}$.) produce beautiful, large, white flowers on long, slender stems the entire season. Price: Pkt., 10c; $1 / 2$ oz., 40c.

GIANT PINK-Scarlet, Striped, Yellow. Price: Pkt., 5e; $1 / 2$ oz., 40c.

GIANT MIXED-A showy border plant. Excellent for cutting. A fine winter bloomer also. Blooms the first year. $1 \frac{1 / 2}{2}$ ft. t. P. Price: Pkt., 5e; 1 oz., 20c.

TOM THUMB VARIETIES, Mixed Colors-Only $1 \mathrm{ft}$. high. Price: Pkt., 5c.

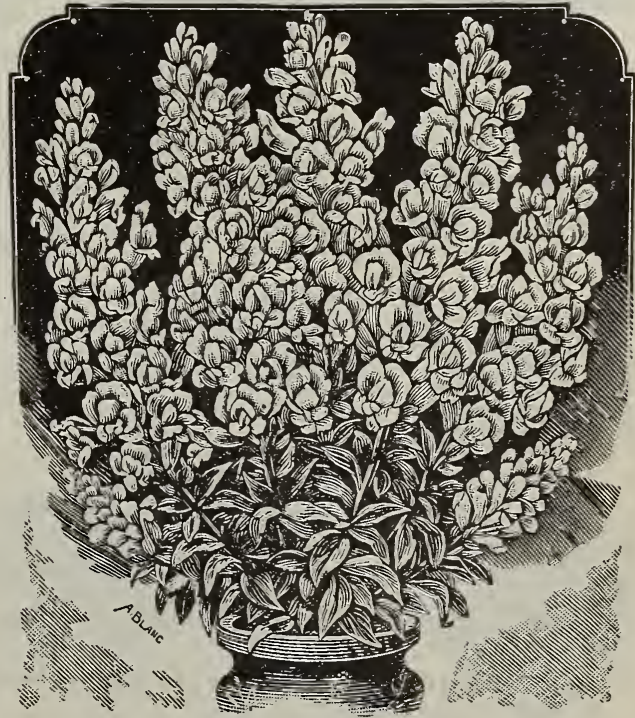

Antirrhinum 

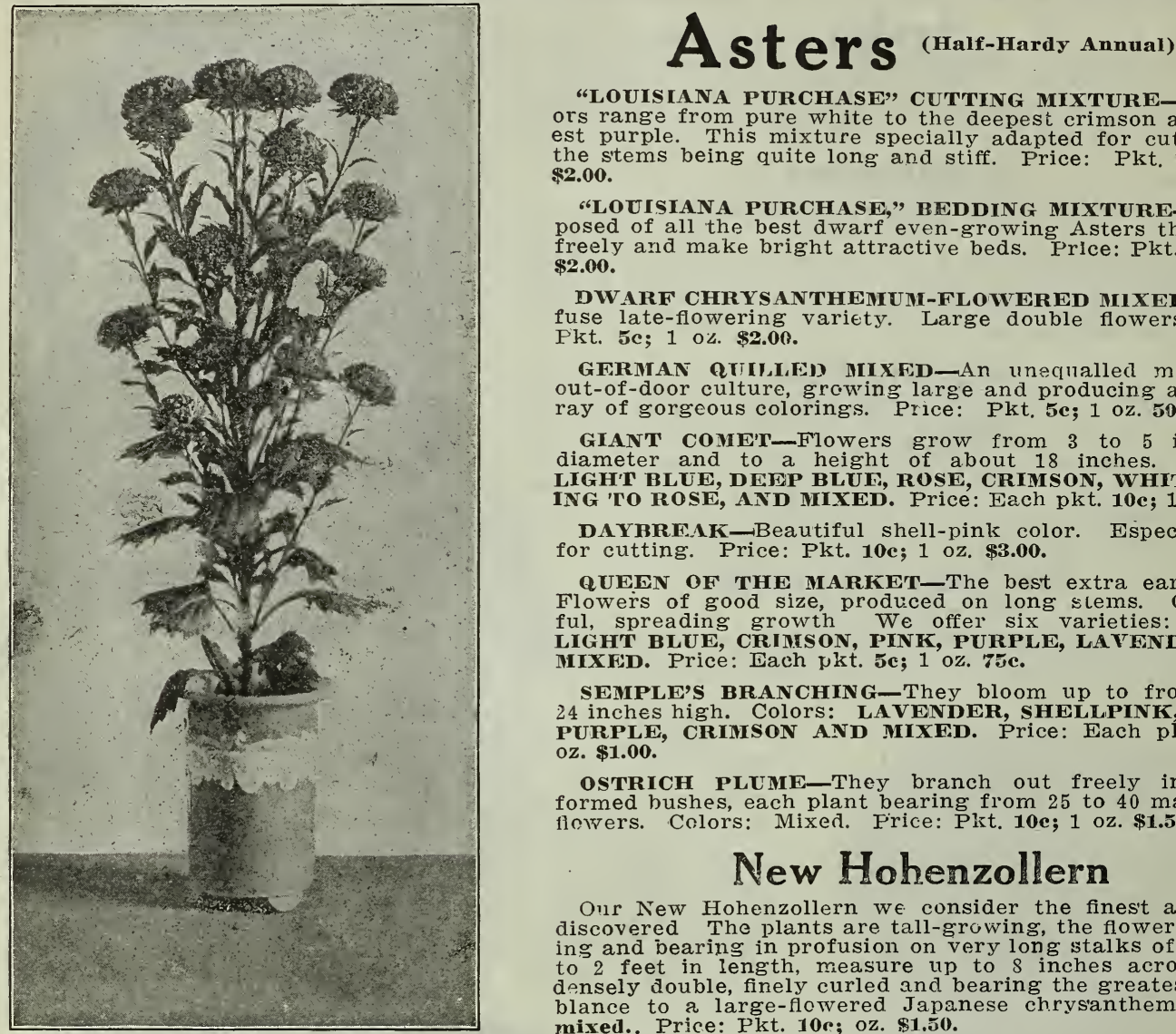

"LOUISIANA PURCHASE" CUTTING MIXTURE-The colors range from pure white to the deepest crimson and darkest purple. This mixture specially adapted for cut flowers, the stems being quite long and stiff. Price: Pkt. 10e; 1 oz. $\$ 2.00$.

"LOUISIANA PURCHASE," BEDDING MIXTURE-Is composed of all the best dwarf even-growing Asters that bloom freely and make bright attractive beds. Price: Pkt.10c; $1 \mathrm{oz}$ $\$ 2.00$.

DWARF CHRYSANTHENUM-FLOWERED MIXED-A profuse late-flowering variety. Large double flowers. Price: Pkt. 5c; 1 oz. \$2.00.

GERMAN RTIMIED MIXXED-An unequalled mixture of out-of-door culture, grcwing large and producing a brilliant ray of gorgeous colorings. Price: Pkt. 5e; 1 oz. 50e.

GIAN'T COME'T-Flowers grow from 3 to 5 inches in diameter and to a height of about 18 inches. WHITs, LIGH'T BLUE, DEWP BLUE, ROSE, CRIMSON, WHITE PASSING 'TO ROSE, AND MIXED. Price: Each pkt. 10e; 1 oz. \$1.50.

DAYBREAK-Beautiful shell-pink color. Especially fine for cutting. Price: Pkt. 10c; 1 oz. \$3.00.

QUEEN OF THE MARKET-The best extra early Aster. Flowers of good size, produced on long slems. Of graceful, spreading growth We offer six varieties: WHITE, LIGH'T BLUE, CRIMSON, PINK, PURPLE, LAVENDER AND MIXFD. Price: Each pkt. 5c; 1 oz. 75e.

SEMPLE'S BRANCHING-They bloom up to frost; 18 to 24 inches high. Colors: LAVENDER, SHELLPINK, WHITE, PURPLE, CRIMSON AND MIXED. Price: Each pkt. 10e; 1 oz. $\$ 1.00$.

OSTRICH PLUME-They branch out freely into wellformed bushes, each plant bearing from 25 to 40 magnificent fiowers. Colors: Mixed. Frice: Pkt. 10e; 1 oz. \$1.50.

\section{New Hohenzollern}

Our New Hohenzollern we consider the fines't aster ever discovered The plants are tall-growing, the flowers branching and bearing in profusion on very long stalks of from $1 \frac{1}{2}$ to 2 feet in length, measure up to 8 inches across, being densely double, finely curled and bearing the greatest resemblance to a large-flowered Japanese chrysanthemum. Fine mixed.. Price: Pkt. 10c; oz. \$1.ฮ0.

\section{Begonia}

A beautiful flower of various colors. Blooms in constant profusion from early summer until late fall, and an excellent plant for winter blooming. T. P.

SEMPIR FLGFEN EE MIXED-Similar to above, only colors mixed. Price: Pkt. 10e.

BEGONI REX-Fine for growing in pots. With perfect habit. With beautiful foliage. Price: Fkt. 25e.

\section{Banana (Musa Ensete)}

One of the most effective lawn plants we have, giving a tropical effect to any garden. Should be pianted in a somewhat sheltered place where the wind will not whip about the broad leaves. Plants can be over-wintered in a tuh in the nouse, and be set out again after all danger of frost is over. 8 to $12-\mathrm{ft}$. Price: Pkt. 25c.

\section{Browallia}

BROWAIMIA MAJOR-This new sort is without doubt the most beautiful of all the Browallias. The plants grow only about a foot high and form dense little bushes, which are covered with an abundance of the most delightful sky-blue flowers, much larger than those of the other varieties. For beds, borders or pots there is hardly a plant with jlue flowers that compares with jt. g. P. Price: Pkt. 10c.

\section{Brachycome (swan River Daisy)}

IBERIDIFOLIA MIXFD-Very effective in edgings, beds and rustic baskets. Good for house culture in winter. Always in full bloom. hh. A. Price: Pkt. 5e; oz. 50e.

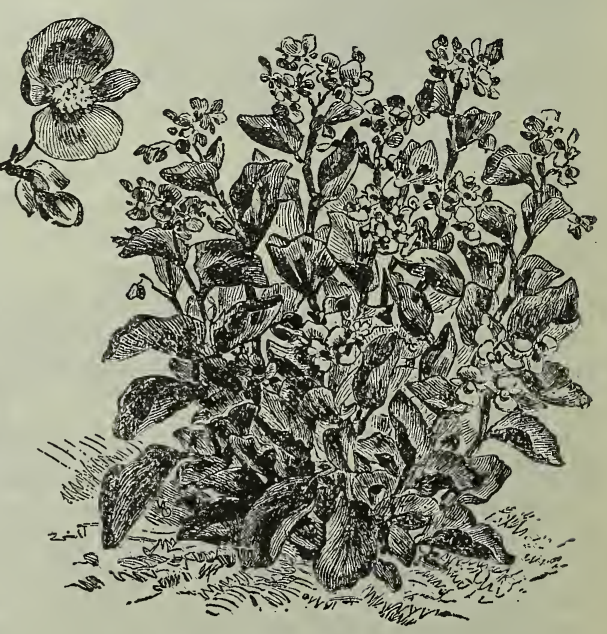

Begonia-Semperfiorence 


\section{Balsam}

These beautiful Annuals have always been popular. Most brilliantly colored, very large. hh. A. $1 \frac{1 / 2}{2}$ to 2 feet.

ROSE FLOWERING-Mixed. Price: Pkt. 5c.

CANEILIA FLOWERED MIXED-Flowers of extra size, double and full centered, with reflexed petals. The most elegant of all Balsams. Price: Pkt. 10c; oz. 75e.

CAMELLIA-FLOWERED PRINCE BISMARCK-Salmon pink, Very double. A pleasing color. Price: Pkt. 10c; oz. \$1,00.

\section{Calliopsis}

One of the most showy flowers, very easily grown: will thrive almost anywhere without trouble or care. A favorite for the home yard or lawn. h. A.

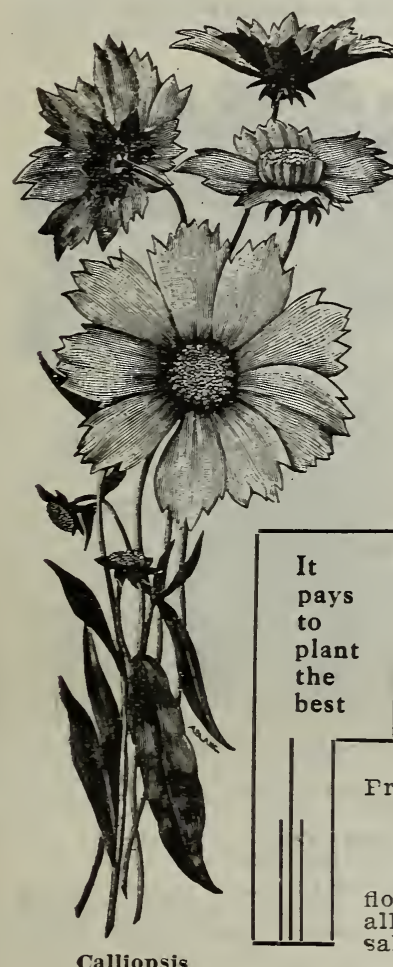

\section{Cosmos}

They make large piants, growing 5 to 7 feet high, which are beautiful masses of the most elegant foliage wintil they begin to bloom, wnen each plant will have hundreds of large, showy olossoms. h. A.

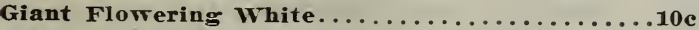

Glant Flowering Pink..................

Giant Flowering Mixed; 0z. 75e............

HYHRID CS MIXED-Price: Pkt. 5c; oz. 40c.

KLONDYKE-The true yellow Cosmos. Price: Pkt., 10c.

BLACK COSMOS (Biden's astrosanquinea)-Of the deepest velvety dark blood-red, appearing near$1 y$ black. $1 \mathrm{ft}$. Price: Pkt. 10c.

EARLY DAWN-Flowers in July. Dwarf-growth white flowers, shaded rose. Price: Pkt. 5e; oz. 50c.

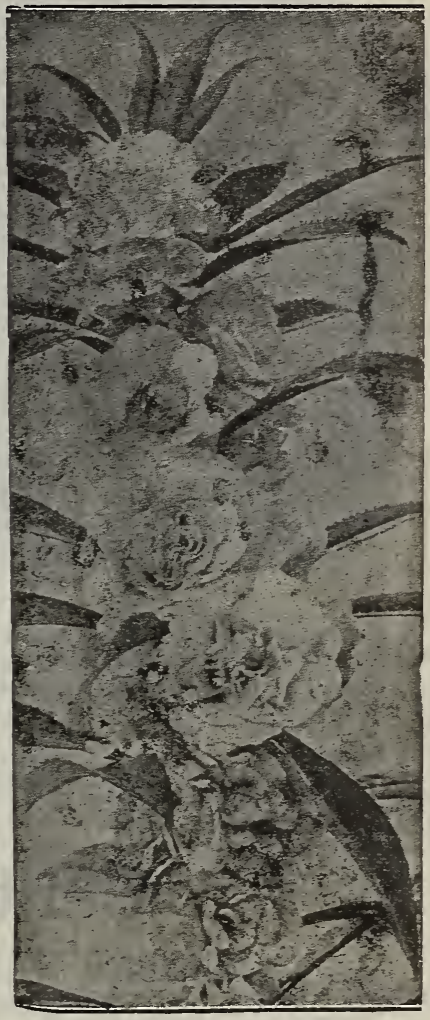

Balsam Rose Flowered

\section{Cotton}

S inches. Price: Pkt. 5c; oz. 25c.

FINE MIXED-Valuable for mixed

SUPERB HYBRIDS, MIXED-Unlike

GOLDFY WIVE-Rich golden yellow. (the A pretty free-blooming plant with Grown extensively for decorating purposes. Tery showy and attractive.

Cannas are famous for their luxuriant growth and immense Gladiolus-like

\section{Canna}




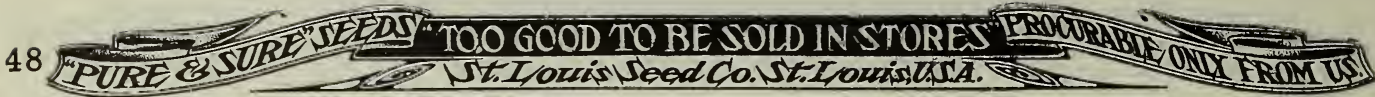

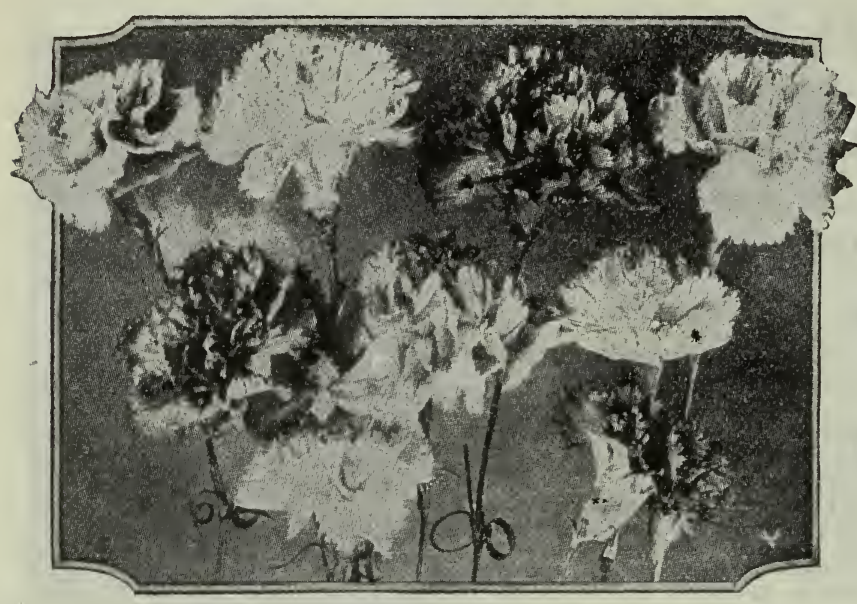

\section{Carnations}

MARGUERITE MIXED-These beautiful Carnations succeed in any good situation Exquisite in color, showing beautiful shades in red, pink, white, variegated, etc. Price, pkt. 5e; 1 oz. 50c.

MARGUERITE WHITE - A beautiful snow white. Price, pkt. 10c.

PRESIDENT MCKINLEY-This valuable new Chabaud-Carnation is of a strikingly bright scarlet color and strongly scented. Fully equal in beauty to the perpetua Carnations and Picotees. It surpasses them in making an early show of flowers. Price, pkt. 15e.

FINEST DOUBLE MIXED-Many colors; saved from the most perfect flowers. About 2 feet. Price, pkt. 10c.

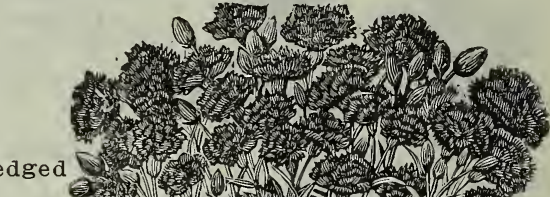
DOUBLE PICOTEE MIXED-Various colors. "Picotee" edged
with purple, rose or red. A distinct class. P'rice, pkt. 20c.

CHABAUD'S EVER-BLOOMING MIXED-Resembles guerite Carnation, but is perpetual growing or perennial Exquisite colors, large flowers. Price, pkt. 20c.

PERPETUAL CARNATIONS-This specie has large, elegantly formed flowers, continually abloom, upon closely branched symmetrical plants, often called, from their neat habit, "Tree Carnations." Finest mixed, pkt. $15 c$.

\section{Centaurea}

(Corn Flower or Bachelor's Button.)

I'his favorite old-time flower is also known as Ragged Sailor Blue Bottle, etc. It is a free flowering bloomer, very showy, grow. ing from 2 to 3 feet high and are largely used for cut flowers. 'It grows in any soil and almost equals the Astor popularity. HA.

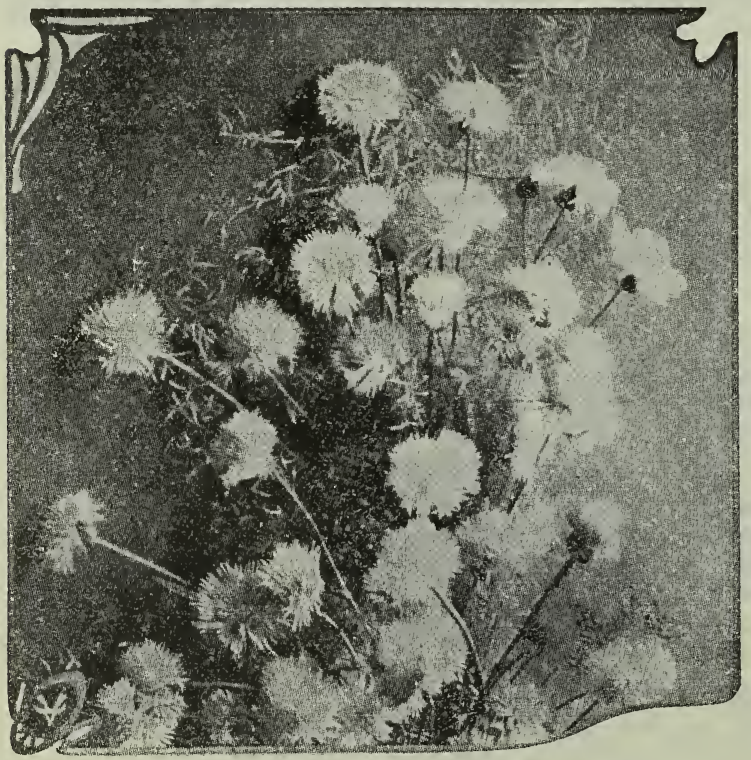

Centaurea-Moschata.

CYANUS KAISER WIIHELM - Rich, deep blue $1 \frac{1}{2}$ feet. Plit. 5c; oz. 20c.

CYANUS SINGLE MIXED-Contains all the popular colors. $1 \frac{1 / 2}{2 t}$. Pkt. 5e; $1 / 2$ oz. 10c.

CYANUS DOUBLE MIXED-A much better strain than the above. Bunch this with Sweet Peas and it makes a pretty combination. Pkt. 10c; $1 / 2$ oz. 25e.

MOSCHATA, OR SIVEET SULTAN-A beautiful new variety, similar to Marguerite, producing freely large, graceful, fragrant flowers on long stems; height about $1 \frac{1 / 2}{\mathrm{ft}}$. Pkt. 5c.

IMPERIALS (Giant Royal Sweet Sultans.)This is a new type of annual Centaurea. Bushes are from 3 to 4 feet in height, flowers are finely fringed, soft and feathery, and frequently 3 inches across. Fine for cutting and of a strong, hardy constitution. Mixed, all colors. Price, pkt. 10e.

ODORATA MARGUERITE-Distinct from all other varieties. Flowers pure white; exceedingly fragrant; long stems. The centers are full and double. Grows quite businy and of the easiest culture. Price, pkt. 10c.

CANDIDISSIMI - Ornamental Leaved Centaurae-(Dusty Miller.) For bedding, hanging baskets and pots and for edging of beds where white foliage is desired. Easily raised from seed. Silvery white, finely cut leaves. 1 foot. Price, pkt. 10c.

GYMNOCARPA-Leaves not so white as the above. $1 \frac{1 / 2}{\mathrm{ft}}$. Price, pkt. 5c. 


\section{CANDY TUFT}

It produces flowers profusely throughout the entire season. For beds, edging, pots and borders, they are in supreme demand. 18 in. h. A.

EMPRESS-The best pure white and the best for cut flowers; fragrant. Price: Pkt., 5e; oz., 30c.

MIXED-Price: Pkt., 5c; oz., 15c.

\section{CALENDULA}

Dwarf bushy annuals, blooming abundantly until frost, of easy culture. $1 \mathrm{ft}$. h. A.

DOLBLE MIXED-Price: Pkt., 5c; oz., 20c.

PURE GOLD-Golden Yellow. Price: Pkt., 5c; oz., 25c.

METEOR-Creamy center, edged with orange. Price: Pkt., 5c; oz., 25c.

\section{CAMPANULA}

(Centerhury Bells) h. B.

SPECLLLM (Venus' Looking Glass)-A Beautiful Blue. Price: Pkt., 5c.

MEDICI CALYCANTHEMA-Blue, Striped, White, Rose and nixed. Price: Pkt., 5c.

\section{CELOSIA \\ (Coxcomb)}

Beautiful plumes of brilliant colors. hh. A. Being fine for vases, and of splendid foliage. Celosia is the finest of all novelty plants, producing very large ostrich-feather-like plumes.

THOMSOY'S MAGNIFICA —A new improved strain. Colors, Golden Yellow, Fiery Scarlet, Purple, Salmon, Blood-red, etc. Price: Pkt., 10c.

OSTRICH PLUME CRIMSON-Price: Pkt., 5̌c.

OSTRICH PLUNE-Golden. Price, 5c.

PYRAMIDALIS-Tall mixed. Price: Pkt., 5e; 1/2 oz., 25c.

CELOSIA, CRISTATA (Coxcomb)-They make attractive beds planted in a mass or as border for other plants. May be dried and kept for years, still retaining their color. hh. A. Yellow and Piuk. Price: Pkt., 10c.

GLASGOW PRIZE-The best dwarf crimson sort, with handsome dark foliage. Combs very large and solid. Price: Pkt., 10c.

DWARF MIXED-Combs often more than 1 foot wide. Price: Pkt., 5c.

\section{CINERARIA}

Magnificent flowering plants for spring decorations for the conservatory or window garden. The flowers measure 2 to 3 inches across, are of white, blue, violet and crimson shades; usually two or more colors are shown in one flower, covering the plant with a sheet of blooms. 20c.

\section{CLEOME}

\section{(Giant Spider Plant)}

Large spikes of rosy purple flowers. Large bushy plant; 3 to 4 feet high. h. A.

PUNGEUS-The finest strain. Price: Pkt., 5c.

\section{COLEUS}

Coleus grown from seed make very thrifty plants the first season. For sub-tropical groups the endless variety and combinations of brilliant colors are very captivating. Price: Pkt., 20c.

\section{COREOPSIS}

A beautiful hardv flower blooming from seed the first year. Very large golden yellow flowers of great elegance and beauty. The plant is covered with flowers the entire summer. Price: Pkt., 5c; oz., 30c.

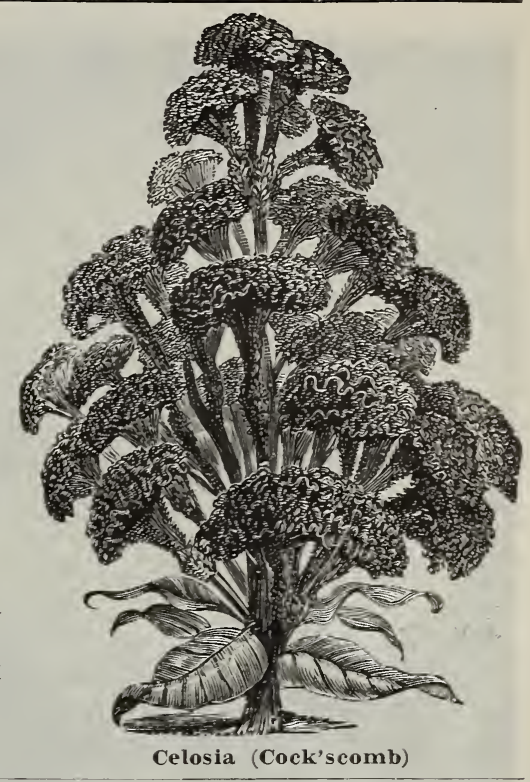

\section{CUPHEA}

(Cigar Plant)

A very pretty border plant. Very showy for borders and bedding. Dwarf habit, hh. A. G.

PLA'TYCENTRA-A favorite Cuphea. Price. Pkt. 10c.

\section{Chrysanthemums}

This Seed will Produce Blooming Plants the First Season.

The real beauty of these Royal Flowers of the Orient is well known. There are many people, however, who do not realize how easily they may be grown from seed, and that all of the mag. nificent new varieties were raised from hybridized seed, similar to that which we are now offering.

ST. L. S. CO.'S CHRYSANTHEMUM "PRINCESS HEVRY"-Most valuable of the maximum type. It is of a very set growth, averaging only about 18 inches high. Very floriferous. The plant is of a globular shape and very decorative, the flowers open for four inches in diameter, and give an abundant and very handsome cutting material. Pure white flowers. Price: Pkt., 10c. 1.5e.

ANNUAL-SINGLE-Mixed. Price: Pkt.. 5e; nz.,

CORONARILM, IUTTRLE-One of the latest introductions in the Chrysanthemum world. Owing to its magnificent golden yellow and white shades it is fast becoming a florist favorite. Price: Pkt., 5c; oz., 30c.

JAPANESE PERENNIAL-The seed we offer is saved from a collection of 50 different varieties from Japan. If this seed is sown in February and March, and properly treated, the plants will bloom profusely next fall equal to any plants started from cuttings. Mixed. Price: Pkt., 20c.

THE BRIDAL ROBE-Of very compact and upright habit; 10 inches in height; the sturdy plants throw out their finely feathered foliage from the base and deck themselves with a mantle of extra double pure white flowers. With their short, closely-set petals the latter recall the finest forms of very large-flowering double Daisies. Chrysanthemum Bridal Robe from seed has certainly proven a bedding plant of the very first rank, while also useful for pot culture. Price: Pkt., 20c. 


\section{Dianthus}

(Pinks)

In this large and greatly varied genus are some of the most beautiful and best-loved flowers, unsurpassable for color and fragrance.

ST. L. S. Co.'S SNOWDRIF'T-Our new Snowdrift may be classed the Ideal Dianthus. Its robust and freely branching plants throw up a multitude of strikingly large flowers, 3 to 4 inches across, very double and with finely laciniated petals of the purest white. Price: Pkt., 15c.

HEDDEWIGII, DOUBLE MIXED-Price: Pkt., 10c.

HEDD. DOUBLE "FIREBALL"-Brilliant scarlet; very compact and floriferous. Price: Pkt., 10c. HEDD. DOUBLE DIADEMATUS (Diadem Pink) Mixed colors. Price: Pkt., 10c.

HEDD. DOUBLE ATROPURPUREA - Crimson. Price: Pkt., 10c.

HEDD. DOUBLE SNOWBALL-Pure white. Price: Pkt., 10c.

HEDD. LACINIATUS, DOUBLE MIXED-Exquisite. Price: Pkt., 10c.

HEDD. SINGLE LACINIATUS, MIXED-Price: Pkt., 5e; $1 / 2$ oz., 25e.

CHINENSIS, CHINA OR INDIAN PINKS-One of the most beautiful and satisfactory of summerflowering annuals. The plants are bushy, of symmetrical form, 1 foot high. Finest mixed colors. Price: Pkt., 5e; $1 / 2$ oz., 15e.

IMPERIALIS, FL. PL. (Double Imperial Pink)Mixed colors. Price: Pkt., 5c; 1/2, oz., 20c.

PLUMARIUS (Hardy Grass Pinks, Border or Spice Pinks)-These form those dwarf bushy mat-like plants above which are produced, on long stems, the beautiful fringed Pinks which have been valued for generations. For permanent beds and borders there is nothing better. Fragrant.

PLUMARIUS, SINGLE MIXED (Pheasant's Eye) Price: Pkt., 5c.

PLUMARIUS, DOUBLE MIXED-Price: Pkt., 10c. "ERFUR'T"-The flowers of this new type are larger, are borne more profusely on shorter, stiff stems with a vivid and rich display of colors and markings. The colors include blood red, rose, maroon, purple, pink, blush, spotted, laced, variegated. Usually very double, beautifully fringed, clove-like perfume. Mixed colors. Price: Pkt., 10c.

\section{Datura}

But few people know that Dahlias can be raised from seed and will bloom the first year. If sown early will bloom profusely all fall. Plant them in a shallow box or pan early in March or April, transplant them carefully as their growth demands, and keep the soil moderately moist. When all danger from frost is over, plant them in the bed or border in the garden, and from then on they will prove no more trouble than if the tubers had been used instead of seed.

DOUBLE MIXED-Pkt., 10c.

SINGLE MIXED-Pkt., 5e.

CACTUS MIXED-Pkt., 10c.

\section{Erysimum}

This Annual Border Plant is one of the sweetest scented annuals in cultivation. It is of a beautiful orange yellow coloring, is of free flowering, of bright color and neat habits. It is rapidly becoming one of our favorite bloomers. h. A. $3 \mathrm{ft}$.

PEROFSKIANUM-The favorite orange coloring. Price: Pkt., 5e.

\section{Eschscholtzia}

\section{(California Poppies)}

Beautiful and popular annuals, being of the earliest culture and giving great satisfaction. From spring-sown seeds they flower profusely until late in the autumn, making them inavaluable bedding plants. h. A.

ROSE CARDINAL-A grand variety. Intense carmine. Price: Pkt., 5e; oz., 35e.

MANDARIN-Red flowers, orange within and scarlet without. Price: Pkt., 5e; oz., 30c.

DOUBLE AND SINGLE MIXED-Price: Pkt., 5c; $1 / 2$ oz., 15c.
"ANGEL'S TRUMPET"-A new annual variety and exceedingly fine, bearing great trumpet-like flowers, 6 to 8 inches long, with double frilled interiors; sweet-scented; plants 4 feet high, bushy and free-flowering, of fine sub-tropical effect in the garden. Mixed. Price: Pkt., 5e; oz., 30c.

\section{Daisies} mer and will continue to bloom for years if given slight protection during winter. They are not very particular as to soil, but should be grown where they have a little shade. $h$. P.

DOUBLE SNOWBALL, WHITE-Pkt., 10c.

DOUBLE ROSE LONGFELLOW-Pkt., 10c.

DOUBLE MIXED-Pkt., 10c.

\section{Shasta Daisy}

One of the most satisfactory hardy plants for shrubbery border. Flowers profusely throughout the summer making excellent cut flowers for decorative purposes. Quite a profitable plant to grow as the flowers are in big demand by florists. Price:

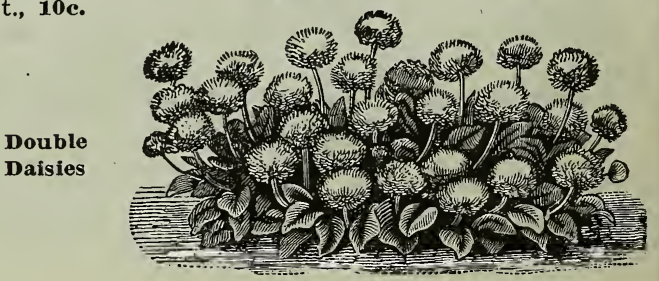

Plants of Double Daisy will bloom the first sumPkt., 10e. 


\section{Euphorbia}

(Poinsetta)

A beautiful plant of exquisite colorings. $h$. A.

VARIEGATA (Snow-on-the-Mountain) Is very popular. Green foliage, veined and margined white; 2 to 4 feet. Price: Pkt. 5c.

heterophyLLA (Mexican Fire Plant or Fire-on-the-Mountain - An annual, resembling the beautiful hothouse poinsetta in habit and color. Smooth, glossy-green leaves, changing to a blazing scarlet, with just a tip of green left; about 3 feet. Price: Pkt. 10c.

\section{Ferns}

A beautiful plant used for foliage, bouquets, etc. Are a favorite everywhere and are very easily grown. Sow seed in rich loam. Below we offer you the finest species.

FINE MIXED - Greenhouse species. Price, pkt. 20c.

HARDY-Species for outdoor culture. Price, pkt. 20e.

\section{Feverfew}

\section{(Matricaria.)}

An old garden favorite. This is the annual Feverfew, and one of the numerous flowers called "Bachelor's Button." Elegant for cutting and bouquet work. h. A.

DOUBLE WHITE-About $2 \mathrm{ft}$. Good for cutting.

Price, pkt. 5c.

GOLDEN BALL-Dwarf. Beautiful yellow. Price, pkt. 10c.

\section{Forget-Me-Not}

(Myosotis.)

These daintily elegant little flowers are hardy perennials that love cool, moist soils, and like pansies, bloom most freely in the fall and early spring. They make beautiful close borders, or edgings, thickly sprinkled with pretty flowersprays, and will bloom nicely in winter in a cool room or coldframe. Once at home in a garden they establish themselves by self-seeding. All the varieties are general favorites. Sow in spring in a warm, sunny border. Most varieties bloom freely the first season and profusely the second. Average height, 6 inches. hh. P.

ROYAL BLUE-Early and free-flowering, with the deepest indigo-blue flowers produced on long sprays, which are excellent for cutting; 9 in. Price, pkt. 10c.

VICTORIA DISTINCTION (Alpestris.) - Bright azure blue. Very early. Price, pkt. 10c.

MYOSOTIS ALPESTRIS-A pretty trailer with blue flowers. Price, pkt. 5c.

MIXED; price, pkt. 5e.

\section{Gaillardia}

\section{(Blanket Flower.)}

Flowers are of extraordinary large size, very highly colored in great diversity of variations and blendings, as dazzling scarlet with gold edge, blood crimson with yellow edge, yellow with orange disc, golden with scarlet border, pure yellow, fiery crimson.

PERENNIAL LARGE FLOWERING-Mixed, h. P. Price: Pkt., 10e; oz., 50c.

ANNUAL LORENZIANA-Double, highly colored as the Perennial. h. A. Price, pkt. 5e; oz. 30c.

ANNUAL LORENZIANA-Single, highly colored as the Perennial. h. A. Price, pkt. 5c; oz. 25c.

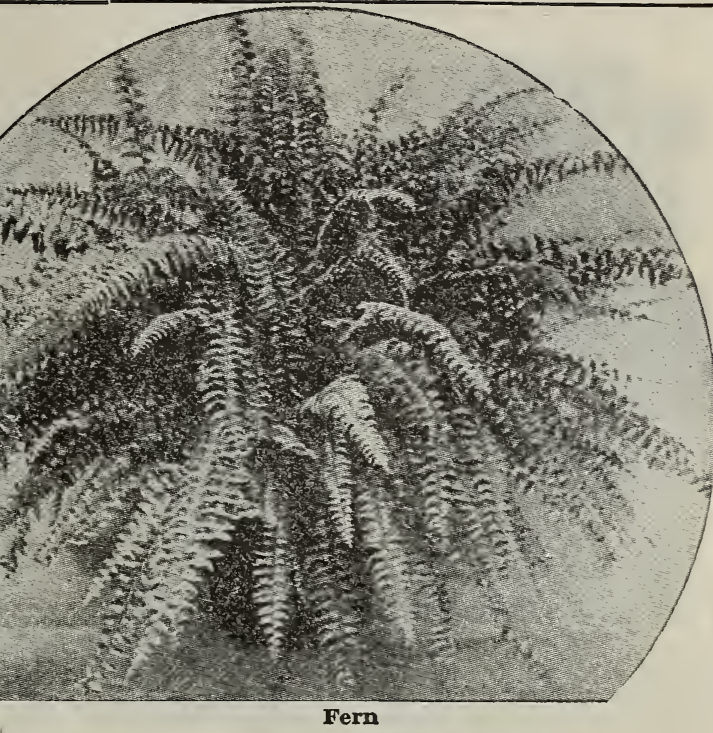

\section{Foxglove (Digitalis.)}

GLOXINIAEFLORA-This is a fine strain of the ordinary Foxglove, with handsome Gloxiana-like flowers on long spikes. Mixed. h. P. Price, pkt. 5e; oz. 30e.

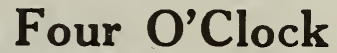

\section{(See Marvel of Peru.) \\ Fuschia (Eardrops.)}

This elegant pot variety is one of our showiest plants. They produce flowers of the most beautiful colorings. g. $P$.

FINEST MIXED-Price, pkt. 25c.

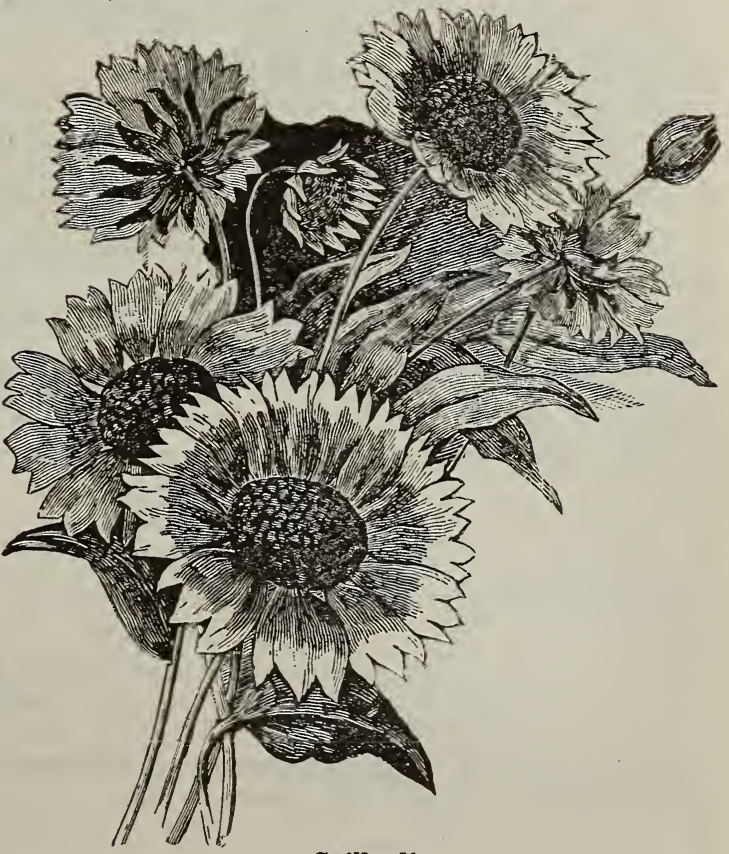

Gaillardia 


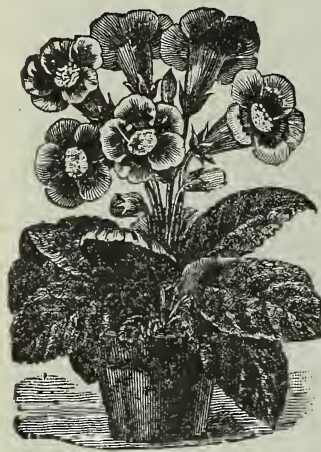

Gloxinia

\section{Geraniums}

These grow readily from seed and produce blooming plants the first summer. There is a great deal of pleasure in watching them develop from seed, and there is always a chance of securing something new and desirable in that way. g. P.

ZONALE, Mixed-Price: Pkt., 10c; $1 / 2$ oz., 25c.

APPLE-SCENTED-Price: Pkt., 25c.

\section{Gloxinia}

Gloxinias are most charming greenhouse plants, of dwarf habit. Their flowers are produced in greatest profusion, and of the most exquisite and gorgeous colors, many of which are magnificently spotted, mottled and blended. Flowers of extraordinarily large dimensions, measuring from $41 / 2$ to 5 in. across. 1 foot. $g$. P.

GIAN'T HYBRIDS, Mixed-Price: Pkt., 25 .

\section{Gypsophila}

Gypsophilas are valuable for bouquet-making, either green or dried. They are very graceful, and easily cultivated. Should be in every garden. All flower the first season. G. paniculata continues to bloom for several years. h. A.

PANICULATA (Baby's Breath)-Flowers white. A hardy perennial which will stay in the ground all winter. Price: Pkt., 5e.
ELEGANs, Pure White-Splendid for carpeting in rose or lily beds. Price: Pkt., 5c.

\section{Godetia}

They are of a dwarf habit of growth. The flowers are of handsome shape, in the most brilliant as well as delicate colors, and are produced in marvelous profusion. Of easiest culture. h. A.

Many sorts and colors, mixed. Pkt., 5c.

\section{Heliotrope}

A beautiful flower which produces trusses frequently measuring 9 to 14 inches across. Rich colors and unusually fragrant. 2 feet. $t$. P. GIANT MIXED-Price: Pkt., 10c.

\section{Heuchera}

The foliage is evergreen, flowers fiery coral, shading to brilliant crimson, borne on graceful spikes. A charming cut flower. $h$. P.

SANGUINEA SPLENDENS-Price; Pkt. 10c.

\section{Hibiscus}

Robust garden annuals; large saucer shaped flowers of creamy yellow with purple centers. 2 feet. h. A.

AFRICANUS (Marshmallows)-Price: Pkt., Бc.

\section{Hollyhocks}

(5 to 8 feet high.)

NEW EVEIRBLOOMING DOUBLE ANNUAL-Leaves of this novelty remain bright and green ưntil the autumn. Price: Pkt., 15c.

ALLEGHENY FRINGED DOUBLE MIXED-Flowers mammoth in size, fringed pink to deep red in color. Blooms very early and continues late. Blooms the first year from seed if sown early. Price: Pkt., 10c.

CHATER'S SUPERB DOUBLE-An extra fine strain. The plants are hardy and large, robust growers; the flowers are not closely huddled up like other Hollyhocks. Crimson, rose, sulphur yellow, white and mixed. Price: Each, 10c.

DOUBLE MIXED, Ordinary Varieties-Price: Pkt., 5c; oz., 50c.

\section{Hunnemania}

\section{(Bush Escholtzia.)}

The plants grow into a shrubby bush, 2 feet high, and produce large cup-shaped flowers.

HUNNEM ANIA-FUMARIAEFOLIA-Yellow. 2-3 h. A. Price: Pkt., 5c.

\section{Ice Plant}

(Mesembryanthemum Crystallinum.)

Handsome and curious plant for hanging baskets, rock work, vases and edgings. Trailer. t. A. 6 inches. Price, pkt., 5c.

\section{Impatieus Sultana}

The Zanzibar or Sultan's Balsam. Ideal for either pot or garden cul ture; a tender perennial that cannot be surpassed. It produces waxy bright flowers almost continually winter and summer. Grows about one foot tall, and of a handsome rose color. 2-3 g. P. Price, pkt., 10c.

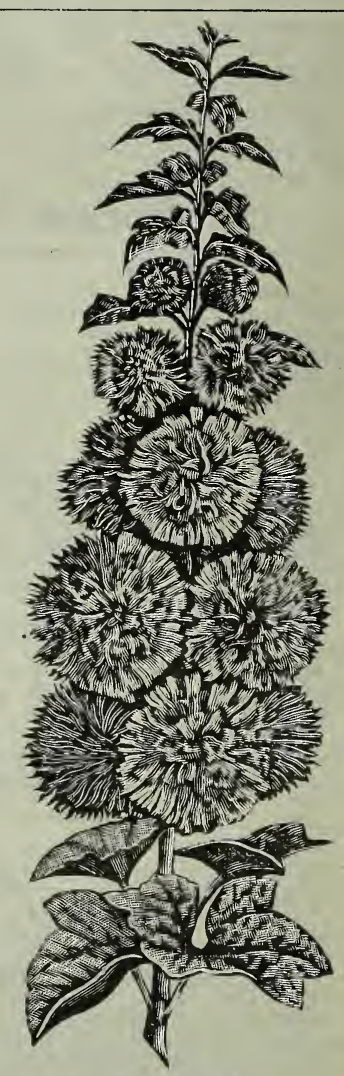

Hollyhocks 
KOCHIA (Burning Bush)

Forms regular pyramids from 2 to 3 feet in height, having a cypress-like appearance. Autumn coloring has given it another name, "Mexican Fire Plant." Plants do best in a sunny exposure about 2 feet apart. h. A. Price: pkt., 10c; $1 / 2$ oz., 25e.

\section{LUPINUS}

Mixed beautiful garden annuals of strong growth. Flowers of various colorings are produced on spikes. Elegant for groups or bordering. Height $1 \frac{1}{2}$ to $3 \mathrm{ft}$. h. A. Price, pkt. 5e; oz. 20c.

PERENNIAL MIXED-3 H. P. Price, pkt. 5e; oz. 30c.

\section{LEMON VERBENA}

The seed of this grand old favorite is very scarce. The leaves are delightfully fragrant and refreshing. Lives from year to year. g. P. Price, pkt. 10c.

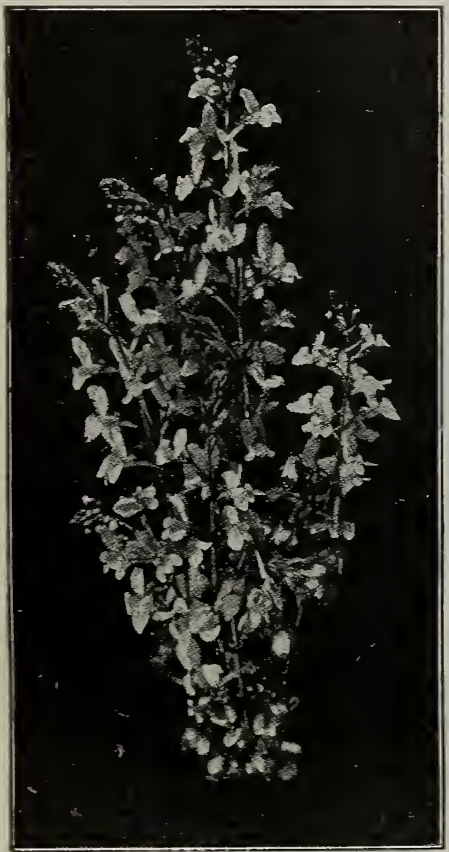

Linaria "Rainbow"

\section{EANTANA}

H X R I D A - Of tall ind slender growth, they will be found a great improvement upon the newer sorts, and a splendid acquisition to our'list of window and garden flowers. A plant suitable to outdoor use in summer and for house zulture. Flowers verbena-like in many colors. g. P. Price: Pkt., 5c; oz. 25c.

RAINBOW-This new creation presents all the colors of the rainbow. "Rainbow" Linaria contains all the shades ranging between dark violet and light blue, dark crimson and pink, also various pure yellow tints. Price, pkt. 10c.

CYMBALARIA (Kenilworth Ivy)-Very pretty new variety, with light green, glossy foliage and violet flowers. h. P. Price, pkt. 10c.

\section{LINIUM (Crimson Flax)}

An unrivaled red annual for small groups and bedding. 1 foot. hh. A. Price, pkt. 5e; oz. 25e.

\section{Larkspur}

(Delphinium)

Annual Varieties.

These include the Rocket and Hyacinth flowered. They bloom best in a rather cool, moist soil.

DELPHINIUM DWAFF ROCIET MIXED-The earliest. Price, pkt. 5e; oz. 25c.

TALL BLANCHING-Very effective and showy planted amongst shrubbery or against the fence, $2 \frac{1}{2}$ ft. Price, mixed, pkt. כe; oz. 30c.

\section{Perennial Varieties.}

These are usually taller than the annuals, requiring more space between the plants.

CHINENSIS GRANDIFLORA (Chinese Mixed)-The stems have many lateral branches, gracefully set with large flowers ranging from pure White to deep Indigo Blue, the paler colors being especially admired. $2 \mathrm{ft}$. Price, pkt, 5e; oz. 40c.

ELATUM (Bee Lurkspur) —Soft, clear Blue; 3 ft. Price, pkt. 10c.

ELATUM DoUBLE-Very showy. Price, pkt. 10c.

FORMosuM-Brilliant Blue, White center; 3 ft. Price, pkt. 10c.

NUDICAULE-The only pure bright Scarlet. Dwarf and compact in growth, with flower stems of fine length; $1 \mathrm{ft}$. A native of California. Price, pkt. 10c.

One Package each of the above perenial varieties for only $35 c$.

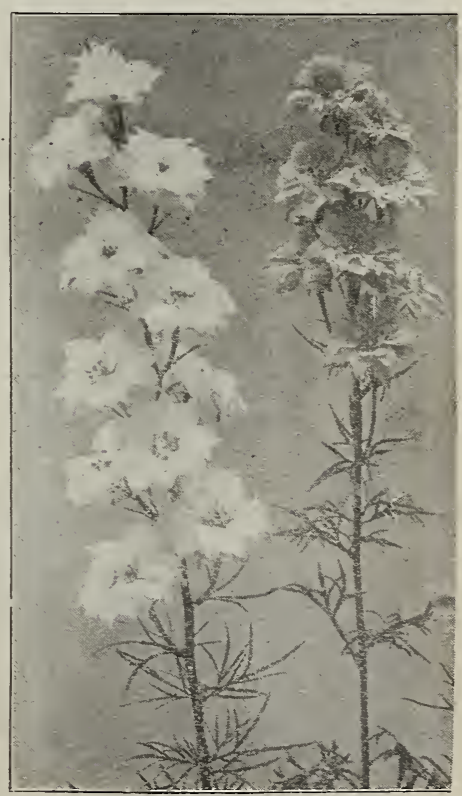

Larkspur 


\section{Lobelia}

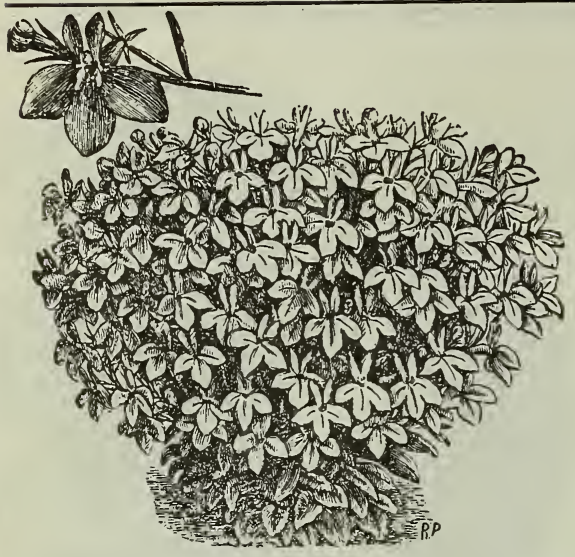

Lobelia

\section{Marigold}

The African and French Marigolds are valuable for their flowers in autumn, and can be grown to advantage in little clumps with other plants in the front of shrubberies or in the garden border. They succeed best in light soil, with full exposure to the sun. h. A.

AFRICAN TALL DOUBLE MIXED-Taller than the French, and the flowers are larger. 2 feet. Price: Pkt., 5e; oz., 20c.

FRENCH DWARF DOUBLE MIXED-Many striped and blotched. Earlier than the African. 1 foot. Price: Pkt., 5e; oz., 20c.

LEGION OF HONOR-Single golden yellow blossoms marked with red. Price: Pkt., 5e; oz., 25c.

\section{Mimulus}

OR MONKEY FLOWERS-Admirable pot plants. The color and markings of the large Gloxinia-shaped flowers; are rich in the extreme, ranging through crimson, maroon, yellow, white and pink, beautifully spotted and blotched.

TIGRINUS MIXED-One foot. 1-3. Price: Pkt., 10c.

MOSCHATUS (Musk Plant)-Foliage emits a strong musky perfume; yellow. 1 foot. 1-3. h. A. Price: Pkt., 5e.

\section{Marvel of Peru}

FOUR O'CLOCKS-Called Four O'clocks because they open their blossoms at that hour in the afternoon. They are also known as "Marvel of Peru." Handsome, free-flowering, sweet-scented; blossoms variegated and striped. h. A.

FINE MIXED VARIETIES-Price: Pkt., 5c; oz., 10c.
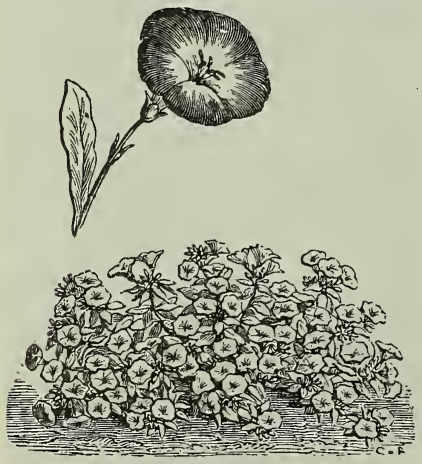

Dwarf Morning Glory c. Price: Pkt., 10c. Pkt., 5c.
Extensively cultivated for bedding, edgings and as pot plant for indoor decoration. Nothing prettier

CRYSTAL PALACE COMPACTA-Large deep blue owers and bronzy foliage. Of fine, close habit. 6 in. rice: Pkt., 10e.

FLorist's FAvorite CoMPACTA (Pumila Splenens)-Brilliant dark blue with white eyes. Very warf. Price: Pkt., 10c.

MAGENTA RED-A splendid red variety with white yes, a beautiful effective plant when used in con10c.

ERINUS TraILING DARK BLUE-Price: Pkt., 5c.

\section{Lychnis \\ (Burning Star)}

HAAGEANA HYBRIDA-Grand hardy perennials, which grow and bloom year after year, requiring no orotection. White rose, vermillion. h. P. Price: Pkt.,
Marigolds, French Dwarf Double

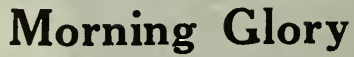

DWARF MIXED-Price: Pkt., 5e; oz., 10c. Nemophila

Splendid annuals for garden decorations; bright colored flowers, in shades of blue, white and violet. 1 foot. $h$. A.

FINEST MIXED-Price: Pkt., 5e.

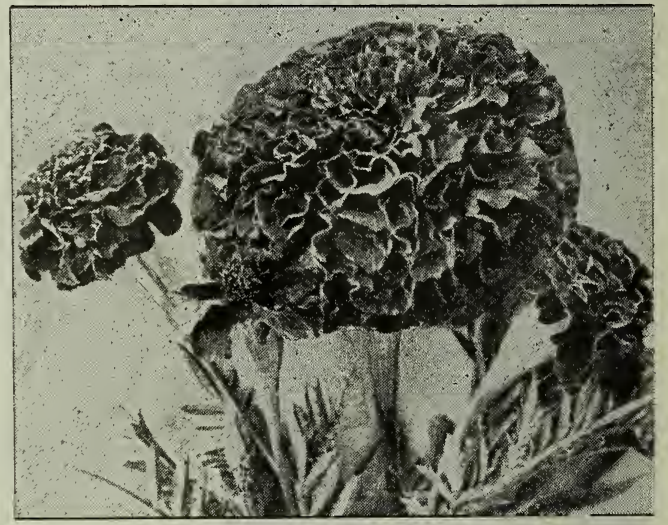

\section{Nicotiana}

\section{(Ornamental Tobaceo)}

A beautiful hardy annual, fine for its sweet-scented flowers and ornamental leaves. h. A.

ST, L. S. Co'S NICOTIANA SANDERAE-A Brazilian novelty, the entire bush being covered with large brilliant carmine red flowers. Height of about 2 feet. An ideal plant to be used for bordering and bedding purposes, as is Salvia, its graceful and copiously branching habit making it one of the most hansdome flowers. It is of a decidedly sweet odor.

COLOSSEA-An imposing foliage plant, 5 to 6 feet; immense leaves, at first rose and violet, afterward changing to deep green, with red veins. Price: Pkt., 10c.

AFFINIS-An annual with sweet-scented, pure white star-shaped flowers, 3 inches across, blooming continually. 2 to 3 feet high. Price: 


\section{Mignonette}

This is one of the grandest garden flowers ever produced, and no garden is complete without an assortment of the following varieties. The color of the florets vary on account of the density of the florets and spikes, thus presenting almost solid columns of brilliant contrasted colorings against the healthy, rich sreen foliage. The fragrance is delightfully rich and powerful. For cutting they are superb, remaining fresh for 8 or 10 days in water. h. A.

ST. L. S. CO.'S "RED GOLIATH" - The spikes of flowers are immense, measuring 6 to 8 inches long by $2 \frac{1}{2}$ inches in diameter, and are compactly filled with giant florets, measuring $1 / 2$ inch across and packed full, even in the center, with anthers, or three times as many as other Mignonettes. The fragrance is delightfully rich and powerful. For cutting it is perfection, remaining fresh for 8 to 10 days in water. Price: Pkt., 10c.

PURE MATCHET-A dwarf French variety, with broad spikes of flowers. Price: Pkt., 5c.

BISMARCK-Can best be described as an improved Matchet. Good for florists. Has stout stalks, dark cream crimped foliage. Price: Pkt., 5c.

ALLEN'S DEFIANCE-Will throw flower stalks of a foot in length and of an unequaled delicious fragrance. Good forcing variety under glass; $1 \frac{1}{2}$ feet. Price: Pkt., 5c.

GIANT PYRAMID-Very beautiful. Slender spikes of light flowers. Price: Pkt., 5c.

LARGE FLOWERING-Mixed. Price: Pkt., 5c; oz.,

\section{Nigella}

(Love in a Mist or Devil in the Bush.)

A compact free-flowering plant with finely cut foliage, curious looking flowers and seed pods; of easy culture, growing in any garden soil; hardy annuals; blue and white mixed; 1 foot. h. A.

DAMASCENA-The finest Nigella. Price: Pkt., 5c; $1 / 2$ Oz., 15c.
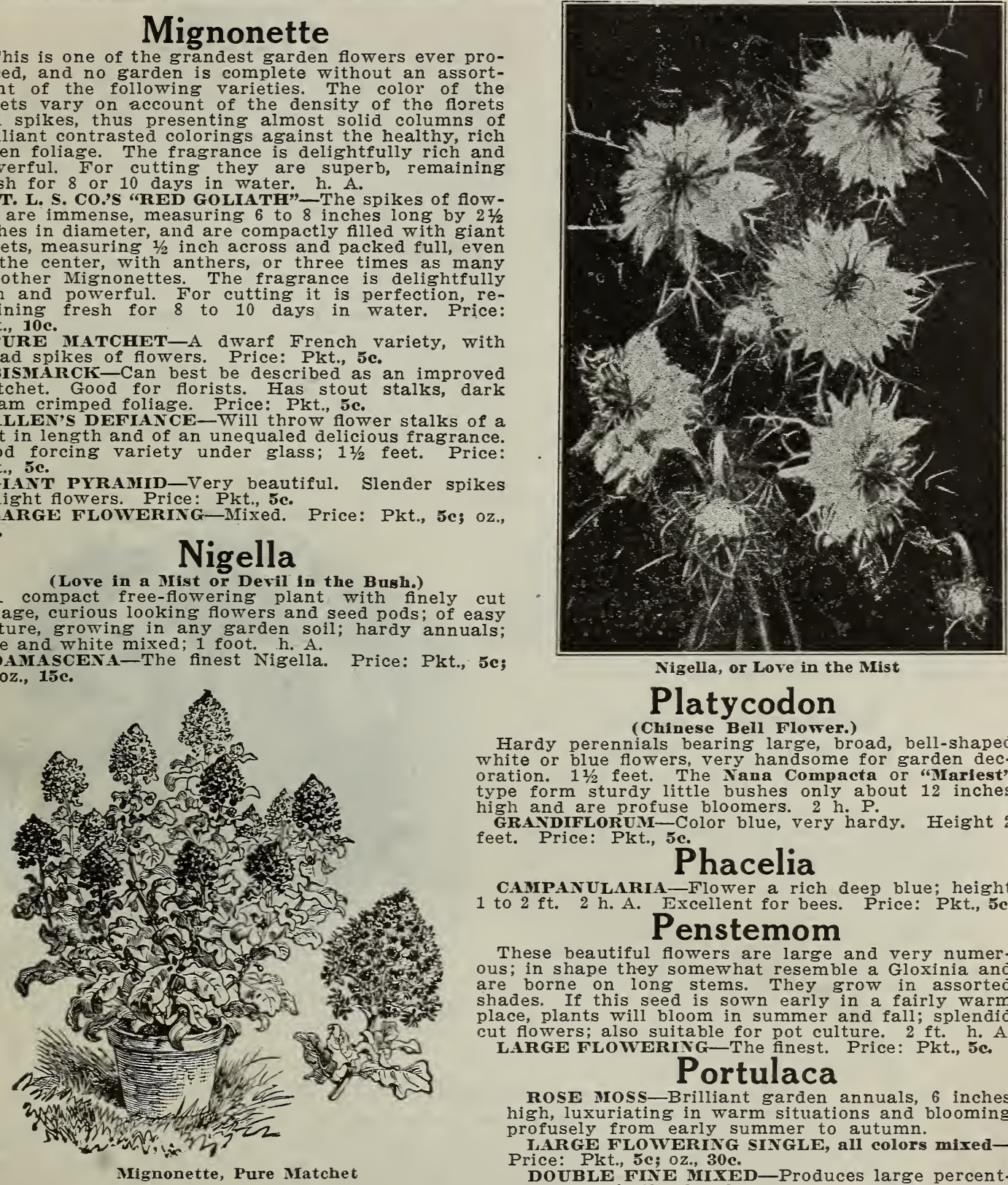

Nigella, or Love in the Mist

\section{Platycodon}

(Chinese Bell Flower.)

Hardy perennials bearing large, broad, bell-shaped white or blue flowers, very handsome for garden decoration. 11/2 feet. The Nana Compacta or "Mariest" type form sturdy little bushes only about 12 inches high and are profuse bloomers. 2 h. P.

GRANDIFLORUM-Color blue, very hardy. Height 2 feet. Price: Pkt, 5c.

\section{Phacelia}

CAMPANULARIA-Flower a rich deep blue; height 1 to $2 \mathrm{ft} .2 \mathrm{~h}$. A. Excellent for bees. Price: Pkt., 5c.

\section{Penstemom}

These beautiful flowers are large and very numer ous; in shape they somewhat resemble a Gloxinia and are borne on long stems. They grow in assorted shades. If this seed is sown early in a fairly warm place, plants will bloom in summer and fall; splendid cut flowers; also suitable for pot culture. $2 \mathrm{ft}$. $\mathrm{h}$. A

LARGE FLOWERING-The finest. Price: Pkt., 5c.

\section{Portulaca}

ROSE MOSS-Brilliant garden annuals, 6 inches high, luxuriating in warm situations and blooming profusely from early summer to autumn.

IAARGE FLOWERING SINGLE, all colors mixedPrice: Pkt., 5c; oz., 30c.

DOUBLE FINE MIXED-Produces large percentage of perfectly double flowers; all colors mixed. Price: Each, 10c.

\section{Perilla}

LACINIATA-A beautiful showy plant. Highly prized for its foliage, producing leaves similar to the Coleus. $1 \frac{1 / 2}{\mathrm{ft} .} 2 \mathrm{hh}$. A. Price: Pkt., 5c; 1/2 oz., 15c. Potentilla

(Flowering Strawberry)

flowers to make them complete

A beautiful (From yellow to bright red. Leaves resemble strawberry plants. An unexcelled plant for border and naturalizing effects. $1 \mathrm{ft}$. h. P. Double sorts mixed. Price: Pkt., 10c. 


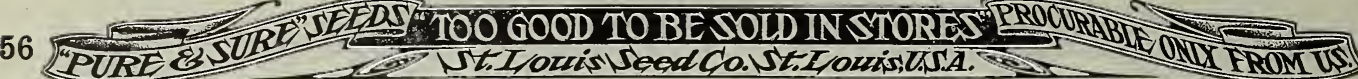

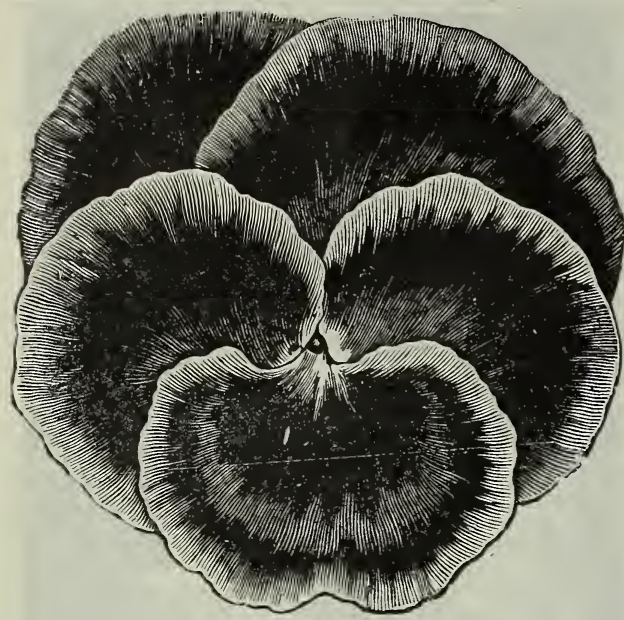

\section{PANSIES}

Most Popular Pansy Mixtures.

ST. L. S. CO.'S "NONPAREIL" MIXTURE-This is certainly one of the grandest collections of the rarest and most beautiful varieties of Pansies. There is no end to the countless shades of color with which nature has endowed this mixture; it is nearly inconceivable. The flowers are of large size and the plants grow more compactly bushy than other mixtures. We control the crop of the European specialists who raise it. Price: Pkt., 20e.

TRIMARDEAU GIANT, MIXED-Extra large flowers, but not of such perfect form as the Imperial German. Most of the flowers have three large blotches or spots. Price: Pkt., 10c.

IMPERIAL GERMAN GIAN'T, MIXED-They embrace all the solid or self-colors, delicately shaded of various colors, dark and light marbled varieties, flowers with clear, distinct eyes, striped flowers of striking beauty and vividly colored fancy varieties. Price: Pkt., 15c.

BUGNOT'S GIAN'T MIXTURE-One of the richest mixtures imaginable; contains the finest blotched varieties; of large size and exquisite colorings. Price: Pkt., 15e.

CASSIER'S GIANT, MIXED-One of the largest blotched variety, with petals of the finest coloring. Price: Pkt., 20c.

ST. L. S. CO.'S LARGE FLOWERING, MIXED-An extra fine strain. Plants compact and produce flowers in great variety of colors. Price: Pkt., 10e; oz., 75e.

MASTERPIECE-This grand new giant Pansy is remarkable in having the borders of the petals waved or frilled, which gives the fower an almost double appearance; the type is altogether novel and distinct. Price: Pkt., 15e.

FINE MIXED-Price: Pkt., 5e; oz., 50e.

\section{Separate Colors}

\section{All Giant-Flowered Varieties.}

FAIRY QUEEN-Delicate blue, margined with pure white.

FIRE KING-Bright reddish brown.

KING OF THE BLACKS (Faust)-Pure jet black.

LORD BEACONSFIFLD-Lavender and violet.

SNOWFLAKE-White.

YELLOW TRIMARDEAU-With black eye.

MAHOGANY-Brown.

EMPEROR WILLIAM-Ultramarine-blue.

GOLD ELSIE-Clear yellow. Price: Pkt., 15e.

Any of the above. Separate colors, not priced, 10e per packet, 3 for 25 .

Size of Bed
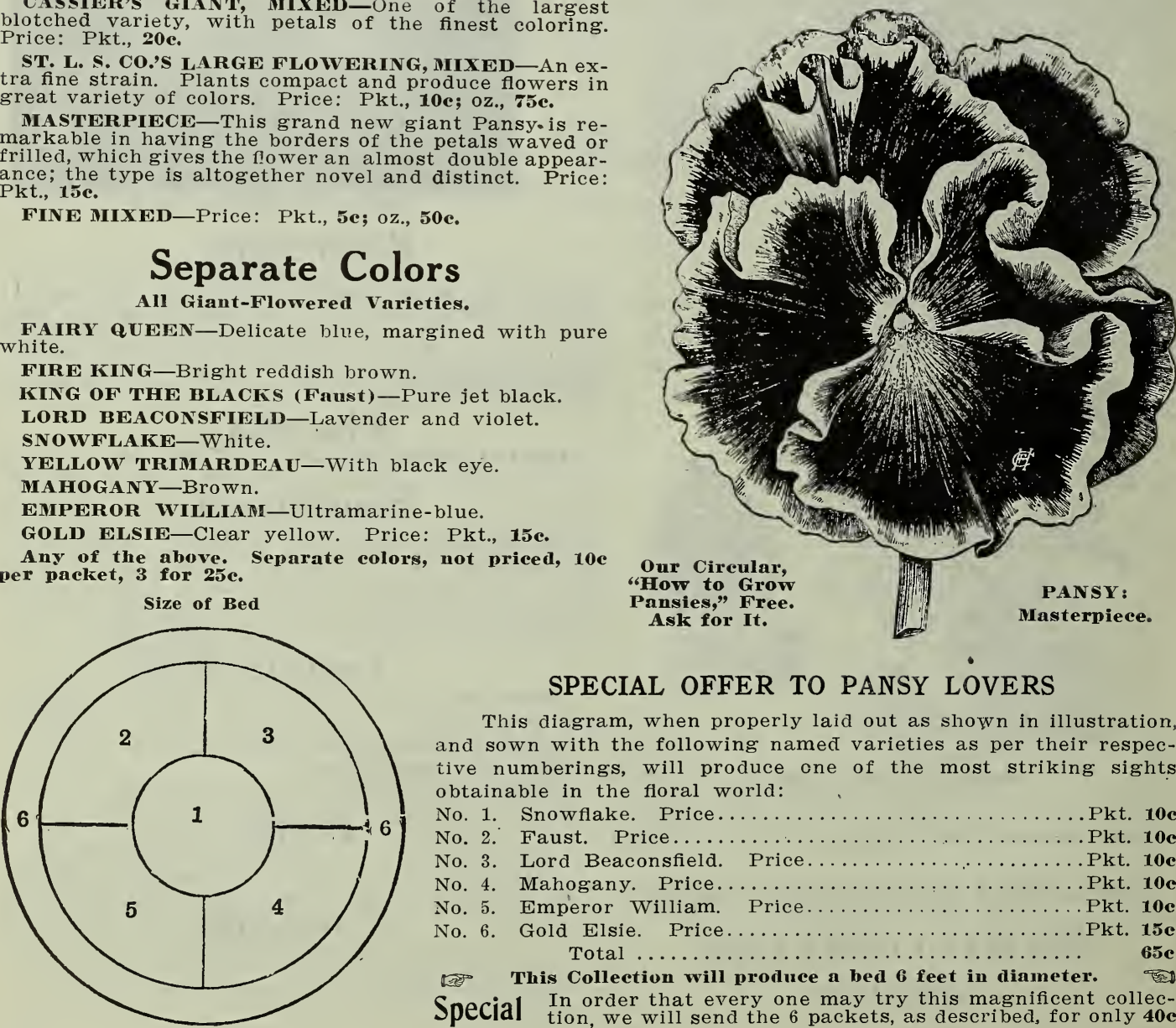

This diagram, when properly laid out as shown in illustration and sown with the following named varieties as per their respective numberings, will produce one of the most striking sights obtainable in the floral world:

No. 1. Snowflake. Price...................... 10

No. 2. Faust. Price........................ Pkt. 10c

No. 3. Lord Beaconsfield. Price.................... 10k

No. 4. Mahogany. Price......................... 10e

No. 5. Emperor William. Price.................... 10c

No. 6. Gold Elsie. Price...................... 15kt. Total ...............................

This Collection will produce a bed 6 feet in diameter. Special In order that every one may try this magnificent collecSpecial tion, we will send the 6 packets, as described, for only $40 c$ 


\section{Petunia}

ST. L. S. CO.'S NEW FOREST PARK PETUNIA-Ii is a strain of incomparable beauty, size and luxuriance. Most of the flowers are exquisitely ruffled or fringed on the edges, and are of enormous dimensions, but their great merits lie in the tremendous variety of colors, markings, veinings, blotches and stripings. Price: Pkt., 25c.

GIANTS OF CALIFORNIA-The richest colors, the largest flowers and the finest markings of all Petunias. Flowers of gigantic size, many of them measuring 5 inches in diameter, and of an astonishing variety of colors. They embrace every conceivable shade of crimson, pink, lavender, pure white, etc., with a diversity of beautiful throat veinings. Price: Pkt., 15c.

FINE MIXED-Many colors; fine for bedding. Price: Pkt., 5e; oz., 40c.

EXTRA CHOICE MIXED-A very choice strain, partly made up from named large-flowering sorts, which will give the greatest variety of colors. Price: Pkt., 10e.

DOUBLE LARGE-FLOWERING FRINGED, MIXEDThe grandest strain of Petunias. Flowers of immense size and variety. Price: Pkt., 25c; 3 pkts., 60c.

DWARF MIXED-Splendid dwarf varieties; large flowering. Price: Pkt., 10c.

ST. L. S. CO.'S KING ALPHONSO PETUNIA-It produces flowers of a very dark crimson color, and are boldly waved and frilled to such an extent that the widely-opened, brilliant black throat of the flower is often almost concealed. Price: Pkt., 20c.

NEW CAN.IRY BIRD PETUNIA-See Novelty Page 42.

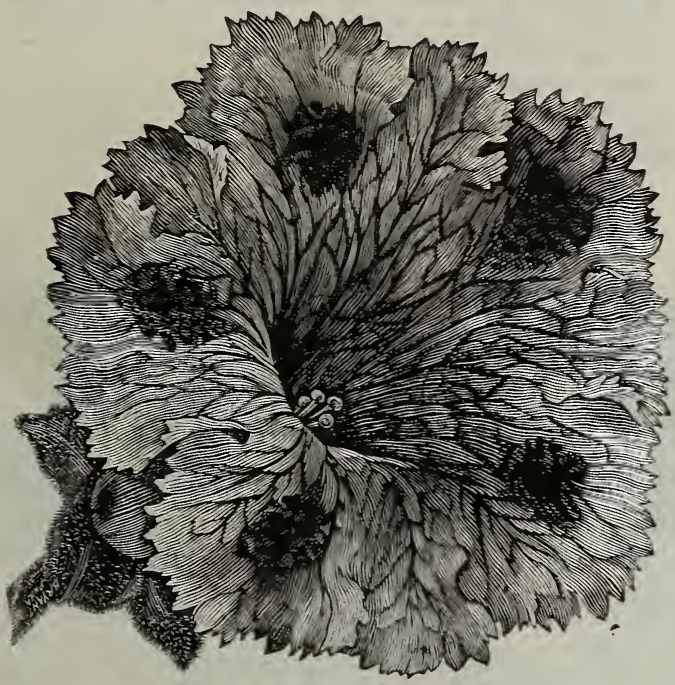

Giants of California, Mixed

\section{Primula (Primrose)}

OBCONICA-This is one of the most useful flowering plants. If sown early in the spring the seedlings will commence to bloom in May or June and continue to flower throughout the whole year. h. P.

GRANDIFLORA-A very profuse bloomer, bearing on long stems, heads containing 10 to 15 flowers. Pure white, shaded lilac. $\leftarrow$ P. Price: Pkt., 10e.

CHINExsis (Chinese Primrose)-The culture of these lovely flowers is much easier than most people think. Our mixture includes all the choicest colors of the single flowering Primulas in all their dainty shadings. Large flowering and fern-leaved mixed. G. B. Pkt., 25c.

AURICULA-Beautiful low-growing early springflowering plants, fine for borders, pot culture, etc.; the fragrant flowers of many rich colors are borne in clusters on the top of stalks 4 to 6 inches long. Pkt., 10c.

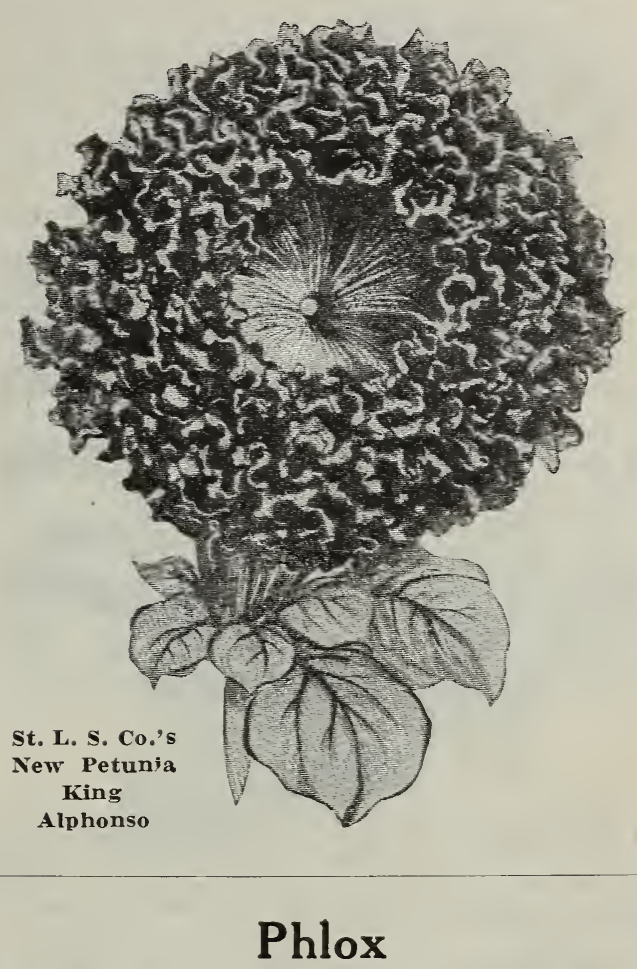

A grand flower for giving solid color effect. The flowers literally cover the beds with their brilliant hues. It is a wonderful bloomer and continues late in the season if not allowed to produce seed.

STARRED AND FRINGED MIXED-Very odd and pretty effect. Price: Pkt., 10c.

LARGE FLOWERING-This important strain is not only notable for variety and brilliancy of colors, but also for the perfection and size of flowers, which are very large and round, the petals overlapping each other. Mixed. Price: Pkt., 10c; oz., 50c.

FINE MIXED-Bright, showy flowers. Good for cutting. 1 foot. Price: Pkt., 5c; oz., 30c.

DWARF PHLOX-This strain grows only 6 inches in height. Plants form round, compact bushes, and are thickly studded with bright, showy flowers, like the taller variety, in all colors. Splendid for bedding, edging and pot culture.

DWARF FIREBALL_Elegant scarlet flowers of fiery hue. Price: Pkt., 10c.

DWARF SNOWBALL-White form of the above. Price: Pkt., 10c.

DWARF MIXED-All colors mixed. Price: Pkt., 5e.

PEREXNIAL MIXED-A fine herbaceous perennial for beds or mixed borders. Price: Pkt., 10c.

\section{Pyrethrum}

(Feverfew) 2, 3; h. A.

ROSEUM HYBRIDEUM GRANDIFLORUM-Flowers of enormous size, ranging in color from light pink and rose to deep carmine. Price: Pkt., 10c. 


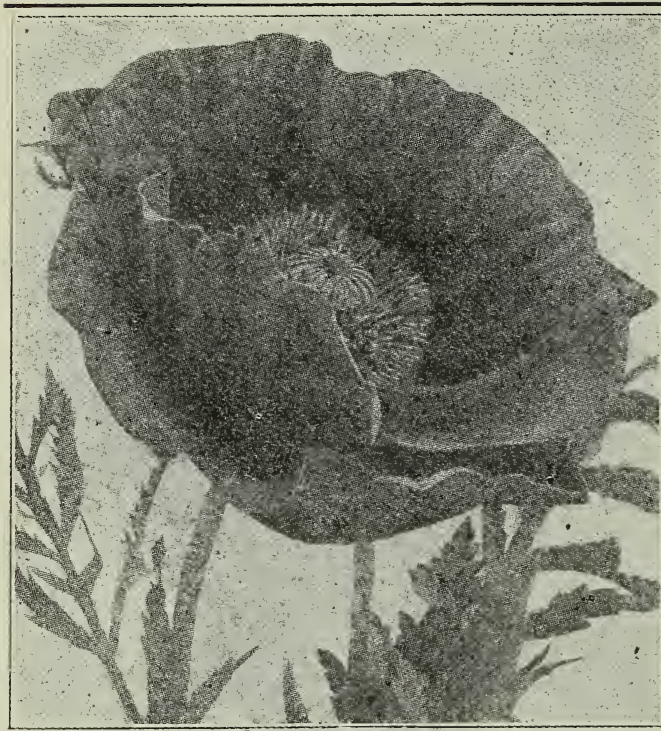

Oriental Poppy

\section{Ricinus}

It makes a perfect pyramid of gigantic leaves. ZANZIBARIENSIS-Surpasses all in size and beauty of colors, which include glaucous-green, coppery brown, metallic red, brownish purple, red maroon and bronze. 8 to 10 feet. Price: Pkt., 5e; oz., 15c.

BORBONIENSIS ARBOREUS The tallest of the Ricinus family. $15 \mathrm{ft}$. Price: Pkt., 5c; oz., 20c.

CAMBODGENSIS-A beautiful black-leaved specie, a handsome foliage. Price; Pkt., 5c; oz., 20c.

GIBSONI-Purplish leaves and stems. $6 \mathrm{ft}$. Price: Pkt., 5e; oz., 20c. MIXED sorTs-Price: Pkt., 5e: oz., 10e.

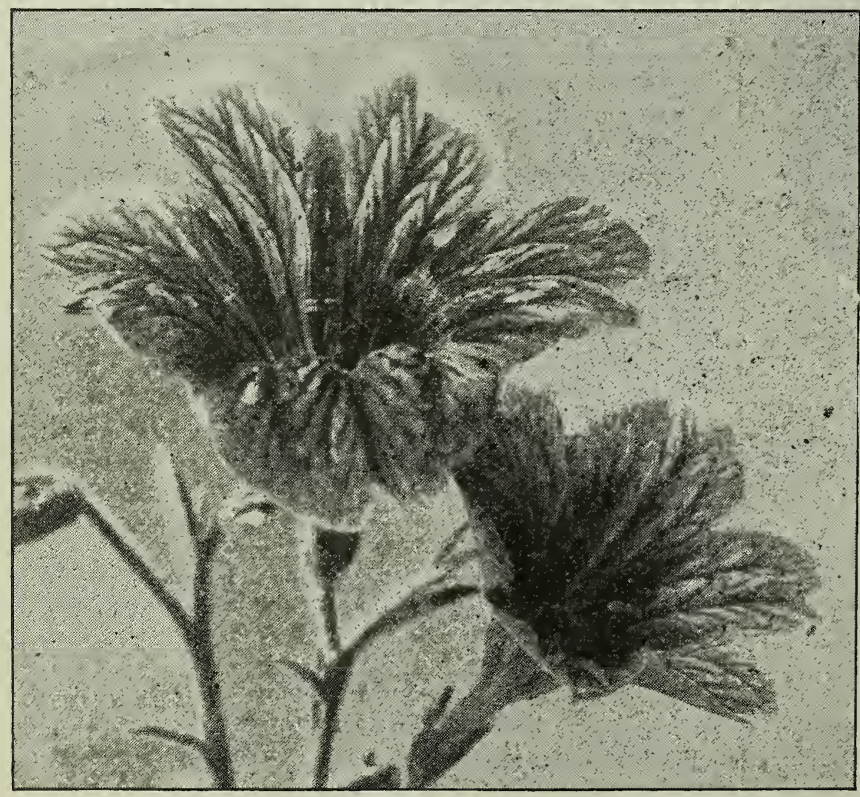

Salpiglossis

\section{Poppies}

DOUBLE CARDINAL-Round as a ball, red as fire. The flowers are of very large size and finely fringed. In color it is a glowing cardinal scarlet of attractive brilliancy, and the long duration of its blooming period makes it a very desirable variety indeed. Height, 16 inches. h. A. Price: Pkt., 5e.

DOUBLE CARNATION - FLOWEIRED - Large, showy flowers. 2 feet. h. A. Mixed. Pkt., 5e; oz., 15e.

WHITE SWAN-A large flowered white form. Price: Pkt., 5c

BRILLIAN' ROSE-Pink type of above. Price: Pkt., 5e.

ORIENTAL HYBRIDS-Large, showy flowers, ranging in color from orange-scarlet to crimson. Very brilliant. h. P. About $2 \frac{1}{2}$ feet. Price: Pkt., 10c.

SHIRLEY - MIXED - This magnificent species sports to numberless shades of color, from pure white to rose, pink, carmine and deepest crimson. h. A. Price: Pkt., 5e.

TULIP-FLOWERED SCARLET - Large, bright scarlet flowers. The two outer petals of the flower form a tulip cup. Strikingly beautiful. About 1 foot. h. A. Price: Pkt., 5e.

DOUBLE-FEATHERED - They are remarkable for the very soft shades as well as for the loose but noble style of their flowers, which distinguish them so prominently to the older somniferum sorts. Pink and rose. h. A. Price: Pkt., 10c.

ICELAND LACINIATED MIXED-White, salmon, rose and orange, with yellow stamens. Petals delicately laciniated and fringed. Dwarf. h. P. Price: Pkt., 10e.

Miss SHFRwoOD-The single Paeony-flowered Poppy bears large flowers of a satiny white, the upper half silky rose. A beautiful combination. Price: Pkt., 10c.

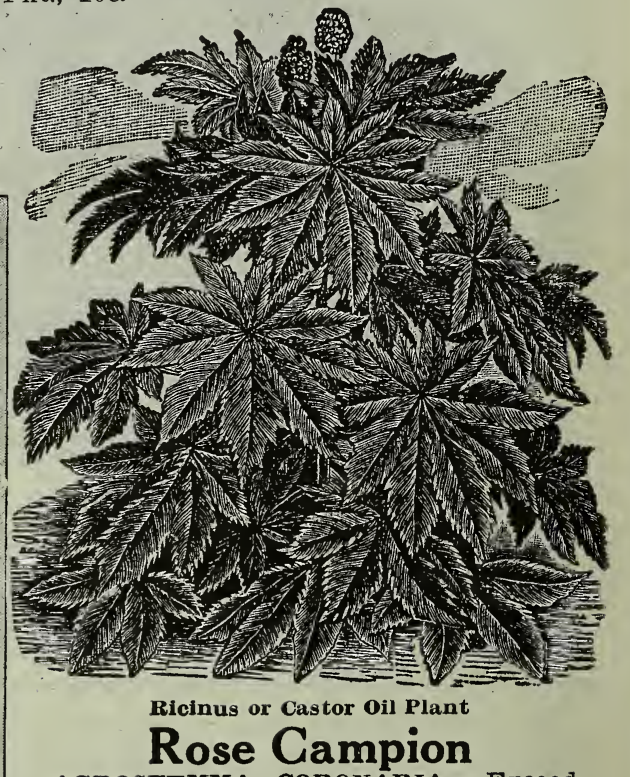

AGROSTEMMA CORONARIA - Exceedingly handsome and free-flowering. Rose pink. h. P. $1 \frac{112}{2 t}$. Price: Pkt., 5e.

Salpiglossis (Painted Tongue)

As pot plants they are elegant and for cut flowers for vase and bouquets they are unsurpassed. 2-3. H. H. A.

LARGE FLOWERED (Painted Tongue) - Yellow, Rose Scarlet, Light Blue, Purplish Violet mixed. Price: Pkt., sc. 


\section{Salvia}

(Flowering Sage) H. H. A.

The plants grow and bloom profusely in any light, rich soil.

SPLENDENS GRANDIFLORA, SCARLET-A rich-flowered bedder. 3 feet. Price: Pkt., 5c.

SPLENDENS BONFIRE-Our well-known compact Salviathe freest blooming of all, seemingly on fire all the time with dense, flaming scarlet spikes. $2 \frac{1}{2}$ feet. Price: Pkt., 10c.

SILVERSPOT-Rich green leaves, elegantly spotted with yellow. The intense bright scarlet flowers are large and lavishly borne; neat and compact. $21 / 2$ feet. Pkt., 10c.

FIREBALL-The most compact type of Salvia yet introduced. Splendid for beds or borders, of somewhat dwarf habit. Price: Pkt., 15c.

\section{Schizanthus}

(Butterfly Flower)

What we have said about Salpiglossis we would repeat for Schizanthus, as they are certainly one of the most beautiful flowers imaginable. The seed must be carefully sown and cared for. 2-3. hh. A.

LARGE-FLOWERED MIXED-As pretty as miniature Orchids. Exceedingly profuse bloomers. Price: Pkt., 5c.

\section{Sensitive Plant}

\section{(Minosa Pudica)}

A curious and interesting plant with pinkish white flowers; the leaves close when touched or shaken, $1 \frac{1 / 2}{2}$ feet. The favorite variety. 2-3; t. A. Price: Pkt., б́c.

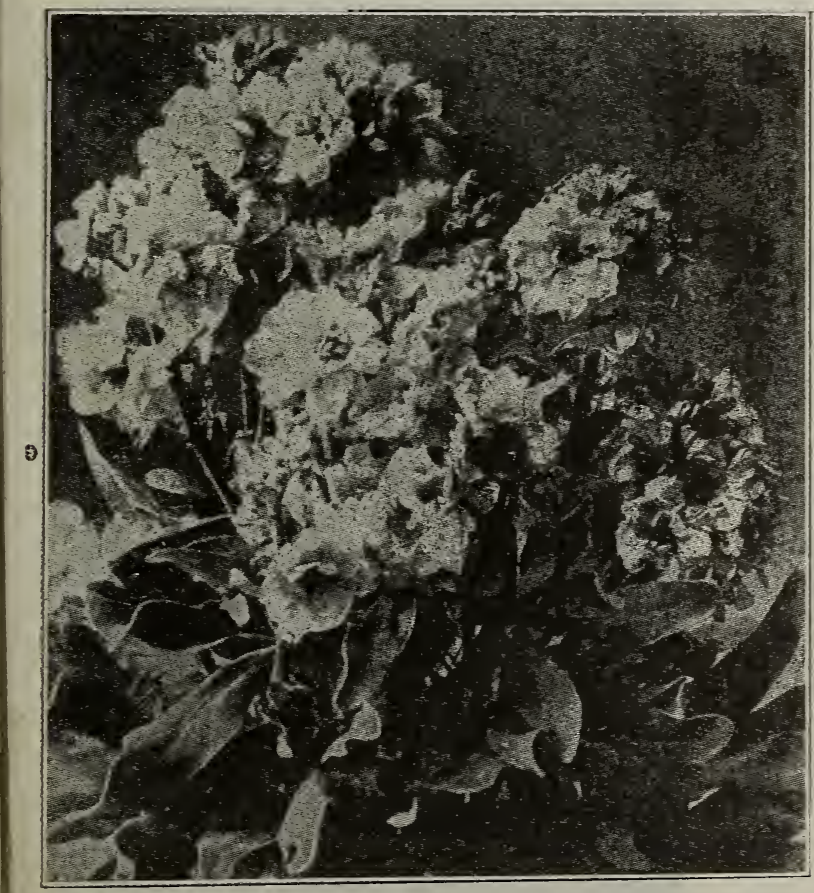

Stocks

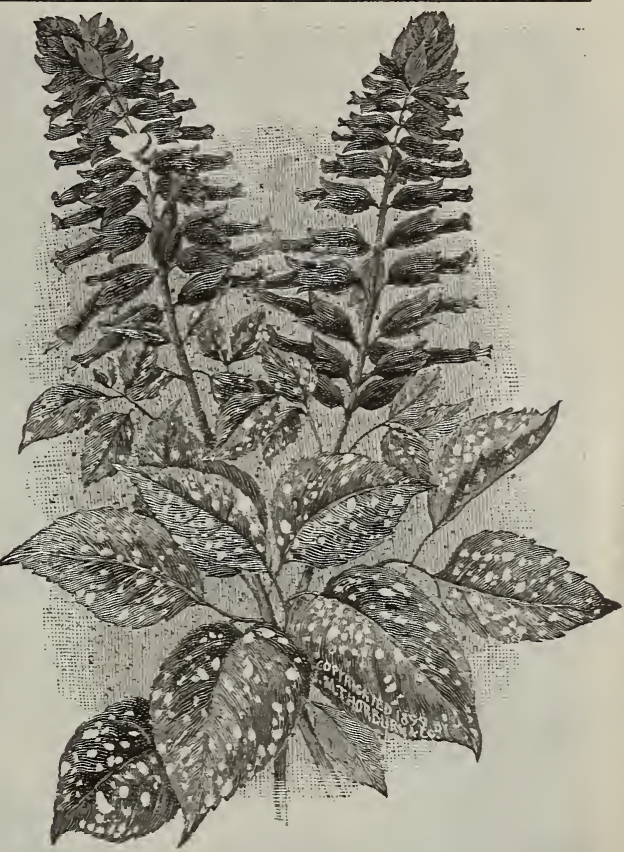

Salvia, Silver Spot

\section{Solanum}

(Jerusalem Cherry)

This is a very useful pot plant for winter decoration. It is of the dwarf branching habit; leaves small and oval-shaped, bearing in the greatest profusion bright, scarlet, globular berries. Very ornamental. 1 foot. 2-3. t. A.

CAPSICASTRUM-A beautiful decorative variety. Price: Pkt., 5c.

\section{Stocks}

The Ten Weeks or Annual Stock has nearly or quite all the requisites of a perfect flowering plant-good habit, fine foliage and beautiful flowers of almost every desirable tint. They will flower finely in winter in a house that is tolerably cool and moist. For this purpose sow seeds late in the season. Although not a constant bloomer, like Phlox, the flowers endure for a long time, and the side shoots give a succession of blossoms when the plant can obtain a needed supply of moisture. Hh. A.

TEN-IVEEK VARIETIES. DRESDEN PERPETUAL (Cut-and-Come Again, or Princess Alice)-Pure white. Plants of robust growth and branching habit. If sown early, commences blooming in June and continues until frost, producing flowers in September and October, when other varieties have faded. Fine cutting. Price: Pkt., 20c.

DOUBLE GERMAN MIXED-The best for ordinary outdoor planting. Price: Pkt., 5c.

LARGE FLOIVERING DOUBLE-Select pot grown German seed. White, red, yellow, blue, purple and mixed. Price: Pkt., each, 10c.

AUTUMNAL OR LATE FLOWERING FINE MIXED-(Intermediate Stocks.) Blossoms in the fall if sown early. HHB. $11 / 2$ feet. Price: Pkt., 15c.

WINTER OR BROMTON MIXED-Remove the plants indoors for winter blooming. Price Pkt., 15̌c. 


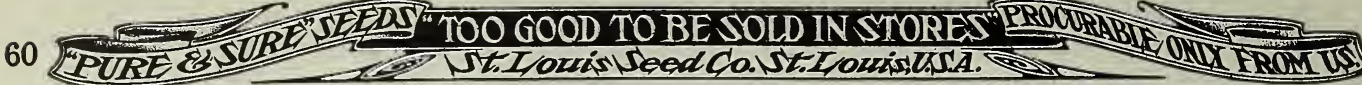

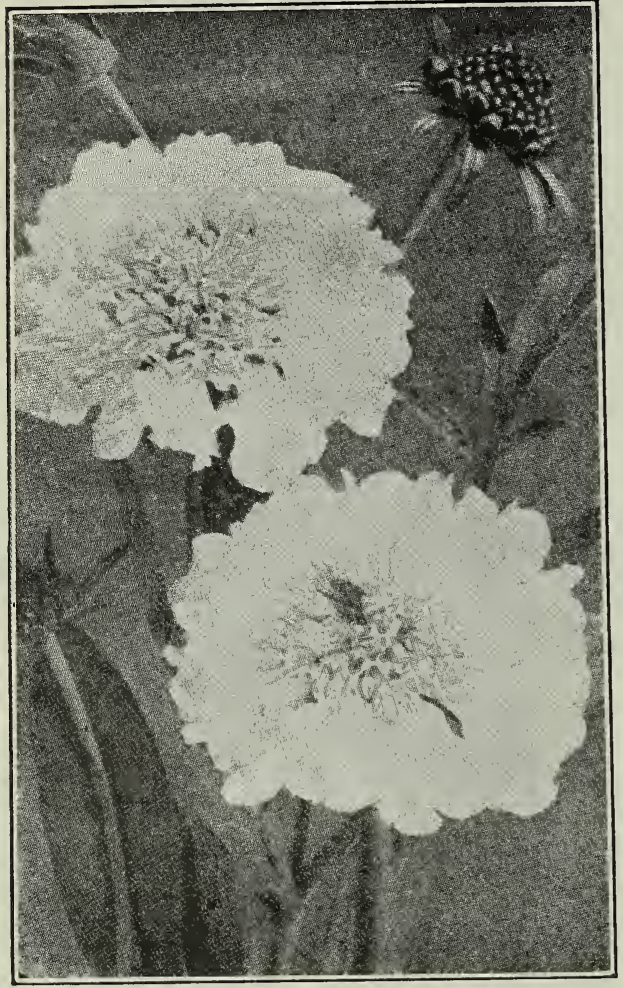

Scabiosa

dollar. Ours is a strain of truly Mammoth Verbena that produces uniformly magnificent trusses of flowers which embrace a wide range of colors, white, purple, scarlet and mixed. Price: Pkt., each, 10c.

GREAT FLORAL CLOCK MIXTURE-This splendid new variety is a very dwarf compact growing BushVerbena with large trusses of pure flesh-colored flowers, a shade previously unknown in this class. Excellent for dwarf beds and borders, and, in fact, superior to any of the other verbena family, producing mammoth trusses of flowers of unusual size and coloring. Price: Pkt., 15c.

FINE MIXED-All the good colors. Price: Pkt., 5e; oz., 50c.

\section{Sunflower (Helianthus)}

Far superior to common Sunflowers. The large, rich olden yellow flowers are produced on each branch. Makes a beautiful hedge. h. A.

GOLDEN BAIL-A beautiful large double variety. Price: Pkt., 5e; oz., 10c.

DWARF DOUBLE VARIEGATED-Similar to the above variety, only of a dwarf nature, with variegated leaves, Price: Pkt., 5c; oz., 15c.

DOUBLE CALIFORNIA-A beautiful, large golden double variety. Price: Pkt., 5e; oz., 15c.

\section{Single Flowering Sorts}

The single Sunflowers are indispensable for cutting. Sown on a sunny spot in April or May, they come into bloom early in summer and keep up a constant supply of flowers until cut down by frost.

CUCUMERIFOLIUS (Miniature Sunflower)-Smallflowered dwarf; single; rich yellow; an abundant bloomer. Price: Pkt., 5c; oz., 25c.

MAMMOTH RUSSIAN- 5 to 8 feet (see Farm Seed Dept.). Price: Pkt., 5c.

\section{Scabiosa (2.3 h. A.)}

Eqveet Seabious, Pinctian Rose, Etc.

They grow about $21 / 2$ feet high and come into bloom early in July, and continue without interruption until frost. The beautiful flowers in exquisite shades condition for the best when cut keep in permake effective borders or beds, and no garden is comlete without Scabiosas, especially where flowers are tor cutting.

.......Pkt., 5e; $1 / 2$ oz., 20c (20.

"

Purple edged White........

\section{Stokesia (Corn Flower Aster)}

Highly valuable for cutting, supplying a shade of oloring not overly plentiful at any season of the year.

CYANEA-The earliest and best sort. h. P. blue. rice: Pkt., 10c.

\section{Sweet Rocket (Hesperis)}

Old-fashioned garden plant, and among the most esirable of hardy flowers; also known as Dame's oret and Dame's Violet; grows from 2 to 3 feet high. P. Fine mixed. Price: Pkt., 5c.

\section{Sweet William (n. P.)}

DOUBLE MIXED-This mixture contains the finest Impossible to find anything that can compare ith it. Price: Pkt., 10c.

SINGLE MIXED-Price: Pkt., 5c.

\section{Verbena (hh. P.)}

ST. I. S. CO,'S MAMMOTH STRAIN-The individual lossoms are frequently larger than a silver quarter in fact, many are scarcely covered by a silver half-

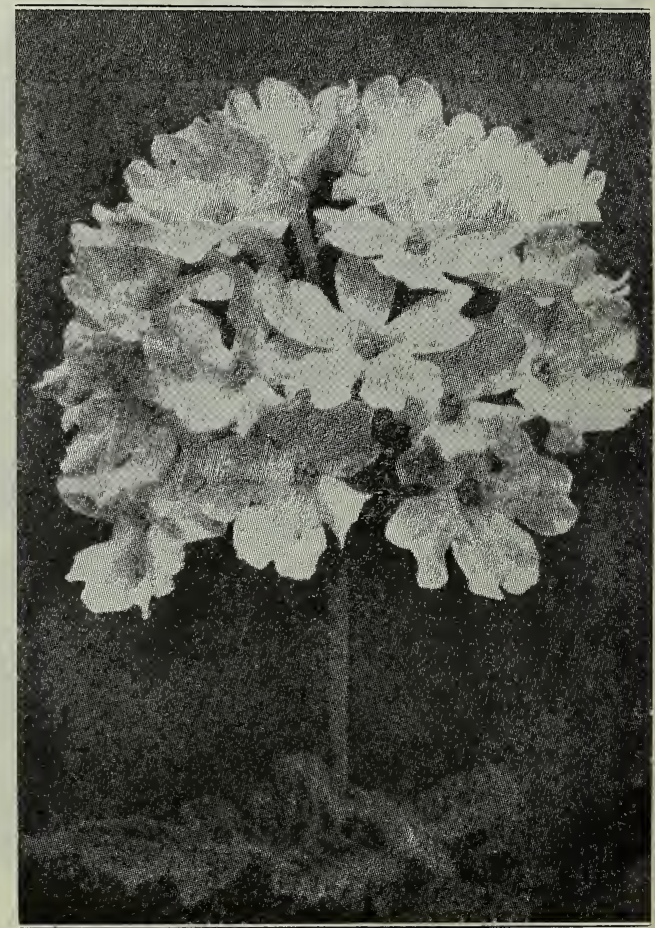




\section{Zinnia}

The plants form handsome little bushes about 15 inches high, and fairly bristle with tiny, short stemmed, very double flowers, hardly exceeding a Daisy flower in size. They are exceedingly pretty plants and bloom all summer long and until late in the fall. $1 \frac{1}{2}$ to 2 feet. h. A. 5e.

EXTRA DOUBLE MIXED-2 feet. Price: Pkt.,

ZEBRA DOUBLE MIXED-A very pretty strain of striped flowers. Price: Pkt., 5c.

MAMMOTH DOUBLE-Of unusually robust habit of growth and immense size. Perfectly formed, very double flowers of various striking colors of white, rose, yellow, scarlet, lilac, purple and mixed. Price: Pkt., each, 10c.

DOUBLE LILIPUT MIXED-Smaller than the ordinary Zinnia, long stiff stems. Valuable for bouquets. Price: Pkt., бc.

DWARF DOUBLE MIXED-Price: Pkt., 5c.

\section{Vinca (Madagascear Periwinkle)}

The Vincas are among our most satisfactory bedding plants: they are very ornamental and bloom freely from early summer until destroyed by frost. In the fall they can be potted for the house, and kept in bloom through the winter. t. P.

ROSEA-Fine rose color. Price: Pkt., бc.

ROSEA ALBA-White, rosy eye. Price: Pkt., 5c.

ALBA PURA-Clear, pure white. Price: Pkt., 5c.

ALL COLORS, MIXED-Price: Pkt., 5е.

\section{Violets (sweet scented)}

VIOLA ODORATA (Semperforens)-Is the wellknown English Violet, a free-flowering hardy perennial. May be grown from seed. Succeeds best in a partially shaded, moist place. H. P. Price: Pkt., 10e.

\section{Virginian Stock}

Charming dwarf annuals, with bright-colored flowers, making the garden gay in early summer. $1 / 2$ foot. h. A.

MIXED-Price: Pkt., 5e.

\section{Wahlenbergia}

See Platycodon-Page 55.

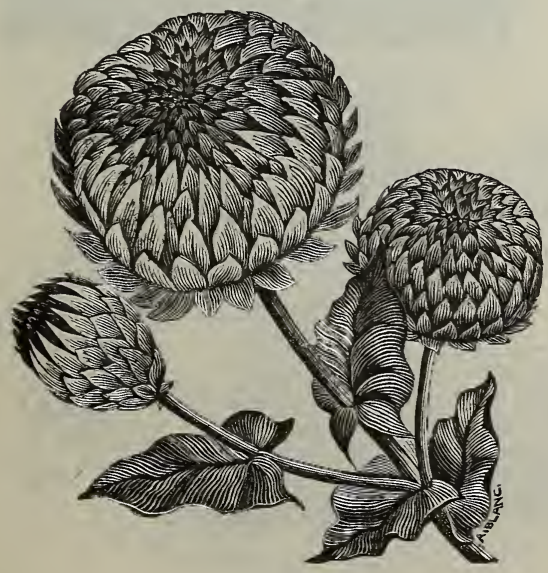

Helichrysum

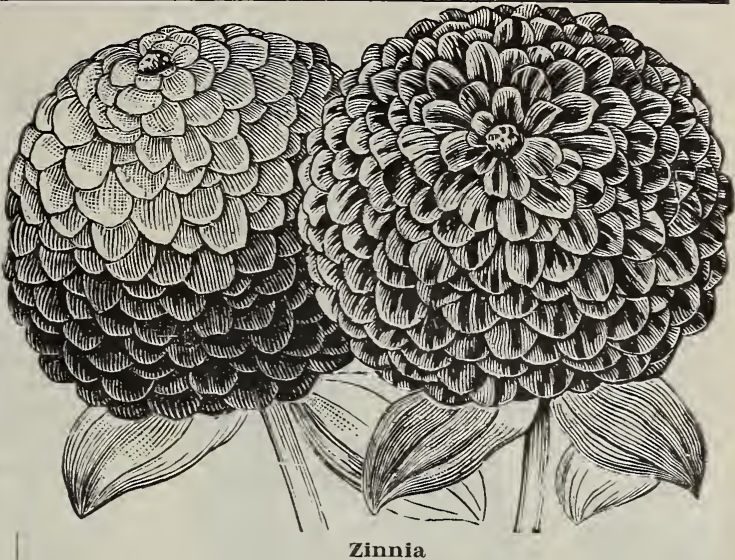

\section{Wall Flower}

A beautiful hardy perennial of exquisite coloring, producing long, showy spikes in abundance.

EXTRA EARLY PARISIAN-Blooms in August and continues until checked by frost; magnificent golden yellow single flowers on long spikes; deliciously fragrant. Price: Pkt., 10c.

DOUBLE MIXED-Price: Pkt., 10c.

SINGLE MIXED-1 foot. Price: Pkt., 5c.

\section{Annual Garden Mixture}

Contains from 40 to 50 varieties of standard hardy flower seeds. Price: Pkt., 5e; oz., 20e.

\section{Everlasting Flowers}

These are mostly annuals, with straw-like flowers that keep their form and color for years. With few exceptions they should be cut just as the buds begin to expand.

ACROCLINIUM ROSFUM-Rose and white mixed, $1 \mathrm{ft}$.

HELICHRYSUM, MIXED - (Bachelor Button). Very ornamental and much admired when dried. Fine double mixed. $3 \mathrm{ft}$.

GOMPHRENA, MIXED-(Globe Amaranth).

HELIPTERUM SANFORDII-Clusters of yellow flowers.

RHODANTHE, MIXED-Pretty for bouquets.

STATICE SUWOROWI-Bright rose color.

Any variety 10 cents per packet. The above 6 packets, 30 cents.

\section{Ornamental Grasses}

For large beds or groups on lawns nothing gives a finer effect and they are now largely used in prominent positions in many of the finest public parks, etc. The follow ing are the most popular varieties.

BRIZA MAXIMA-(Quacking Grass). Very beautiful.

COIZ LACHRIMA-(Job's Tears). $2 \mathrm{ft}$.

GINERIUM ARGENTEUM-(Pampus Grass). The most noble grass in cultivation. $12 \mathrm{ft}$.

LAGURUS OVATUS-(Hare's Tail Grass). Bushy and puffy.

PENNISETUM LONGISTILUM-A favorite among florists for bouquets, etc.

STIPA PINNATA-(Feather Grass).

ORNAMENTAL GRASSES, MIXED-Best varieties. Packet of any of the above, 10e each; 6 pkts., 30e. 


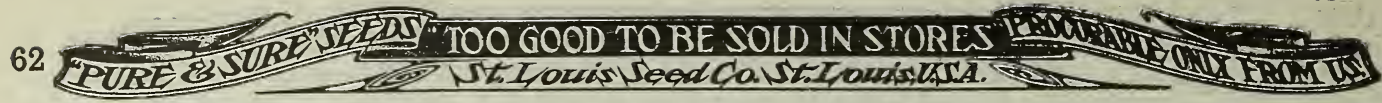

\section{Climbers Worthy of Notice}

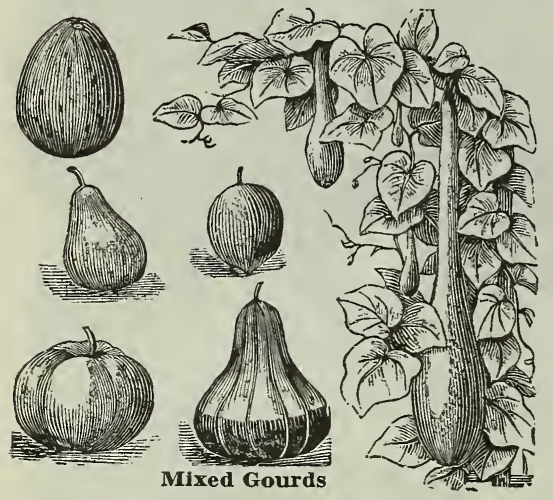

Antigonon (Leptopus)

\section{Ornamental Gourds}

They attain the remarkable growth of from 10 to 20 feet in height and are grown extensively for household as well as ornamental purposes.

DIPPER-Useful for many household purposes. When grown on the ground, produces differently shaped gourds than on the trellis. Price: Pkt., 5e.

DISH CLOTH OR LUFFA-Sponge-like, porous lining is dried and used in the bath or for dishcloth. Price: Pkt., 10c. HERCULES' CLUB-The longest of any of the gourds. Price: Pkt., 5e.

JAPANESE NEST EGG-Resembles hen's eggs in color, size and shape. Price: Pkt., 5c.

SUGAR TROUGH-Very light, but durable. Used for buckets, baskets, soap and salt dishes, etc. Price: Pkt., 5c. MOCK ORANGE-A handsome gourd; very popular. Price:

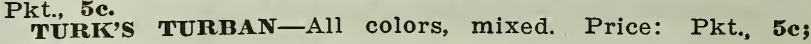
oz., 25e.

S̈MALL VARIETIES, MIXED-Price: Pkt., 5c; oz., 25c.

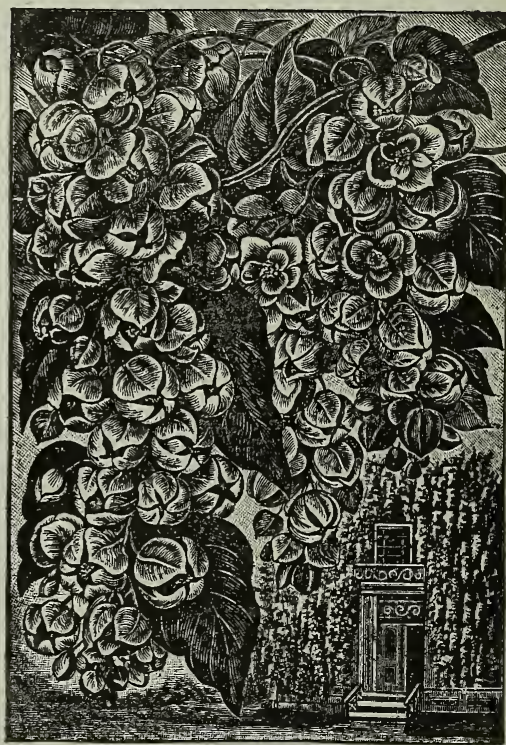

A grand and effective vine when grown in a sunny spot. Bears numerous clusters of deep pink blossoms, completely covering the vine. If outdoors it does best in the South. 3. g. P. Price: Pkt., 5c.

\section{Adlumia (Cirnosa)}

(Mountain Fringe or Allegheny Vine)

A charming, hardy, biennial climber. Feathery foliage, rose-colored flowers. 3. h. B. 15 ft. Price: Pkt., 10c.

\section{Ampelopsis (veitchii)}

Clings to the walls of wood, stone or brick. Dense foliage; glossy green, changing to red and yellow in autumn. h. P. $40 \mathrm{ft}$. Price: Pkt., 5c.

\section{Aristolochia (sipho)}

(Dutchman's Pipe)

Excellent for shade or screen purposes. h. P. Price: Pkt., 10c.

\section{Balloon Vine (Love-in-a-Puff)}

A rapid growing annual climber; succeeds best in light soil and warm situation; flowers white; seed vessels look like miniature balloons. 5 to $10 \mathrm{ft}$. $\mathrm{hh}$. A. Price: Pkt., 5c.

\section{Canary Bird Flower (Tropoelum Peregrinum)}

Charming little canary-colored blossoms resembling canary birds. Very pretty for trellis. hh. A. 10 to $15 \mathrm{ft}$. Price: Pkt.. 10c.

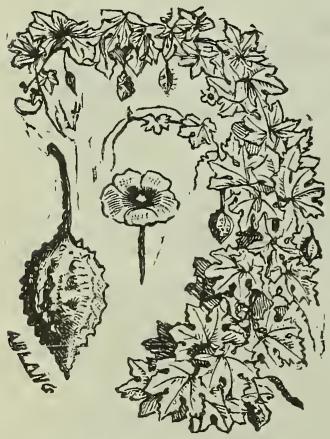

\section{Balsam}

APPLE (Mamordica Balsamina)-A beautiful climbing plant; handsome apple-shaped fruits. Makes dense shade. The fruits preserved in alcohol make a useful liniment. hh. A. 15 to 20 ft. Price: Pkt., 5e; oz., 25c.

PEAR (Momordica Charantia)-Fruits are longer than the apple. Price: Pkt., бe; oz., 25c.

\section{Cypress Vine}

Beautifully twining vine. Its foliage is quite as attractive as its flowers. A continuous bloomer and adapted for any purpose. T. A. $15 \mathrm{ft}$ or more. Scarlet, white and mixed. Price: Pkt., 5e; oz., 15e.

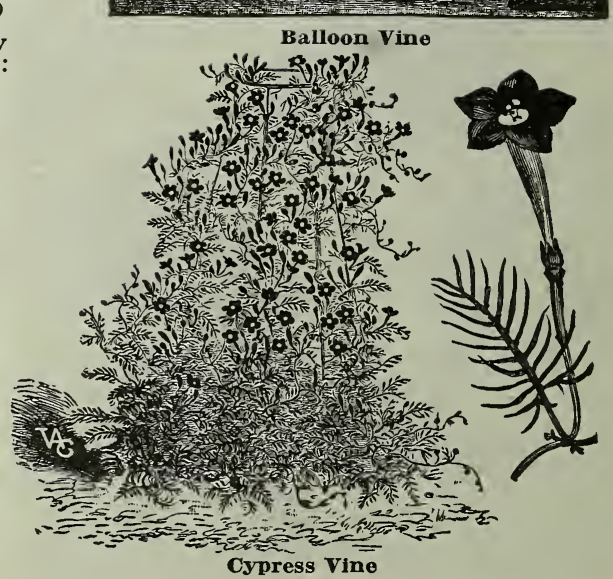




\section{CLIMBERS_Continued}

\section{Dolichos}

(Hyacinth Bean.)

A rapid growing twiner, with attractive flowers and lots of foliage. Will grow anywhere and is very popular. $t$. A. $20 \mathrm{ft}$.

"DAYLIGHT"-This grand Hyacinth Bean comes from Japan. Seed sown late in May will by the middle of July often attain a height of ten feet, and are covered with spikes of snow-white, pea-shaped blossoms from then on until late fall. The heart-shaped foliage is bright green, and are not affected by insect pests of any kind. Price: Pkt., 5c; oz., 10c.

SONDANIEANSIS-The most beautiful purple ever discovered. Similar to the Daylight except in color. Price: Pkt., 5e; oz., 15c.

MIXED COLORS-Price: Pkt., 5e; oz., 10c.

\section{Scarlet Runner Bean}

Price........................... 5kt. $1 / 4$ Ib., 15e

\section{Butterfly Runner Bean}

One of the most beautiful new climbing flowers. The vine is also extremely floriferous; its leaves, of a somewhat lighter green than other runners, almost disappearing beneath the clusters of charming flowers which gracefully rise and fall, like butterflies in the passing breeze. Price: Per pkt., 10e; $1 / 4$ tb., 35e.

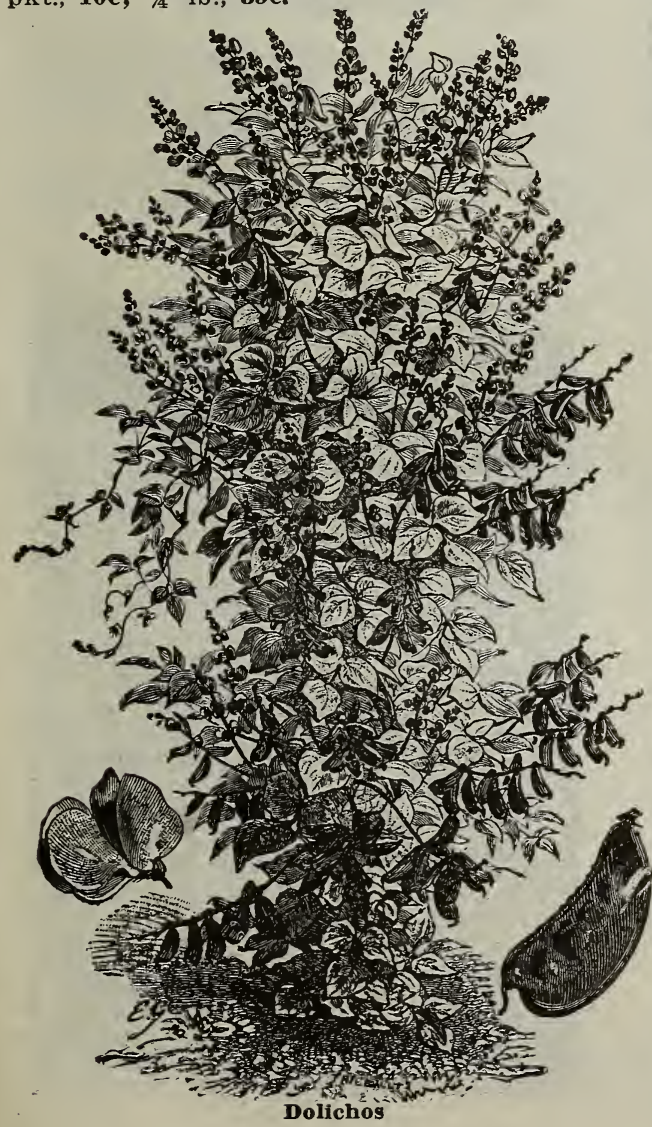

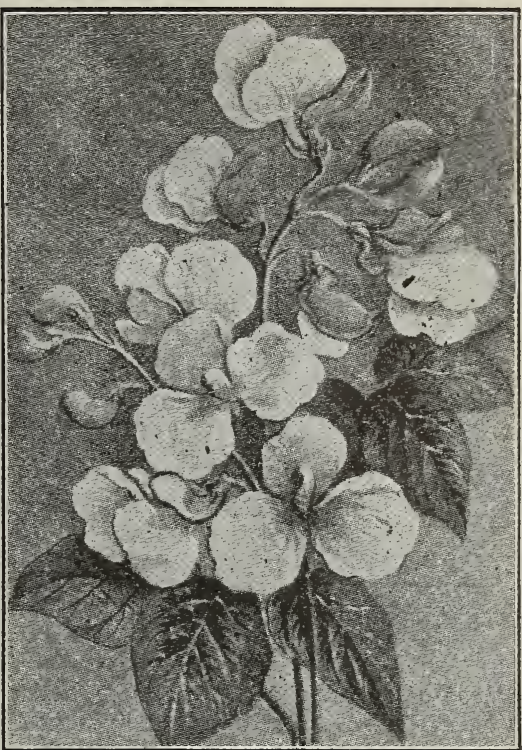

Butterfly Runner Bean

\section{Coboea Scandens}

(Cup and Saucer Vine)

A good tall vine. Foliage heavy, suiting it for shade purposes, and its flowers are attractive. Good for pot culture indoors. t. P. $20 \mathrm{ft}$. Price: Pkt., 5e.

\section{Hop}

JAPANESE VARIEGATED-An excellent rapid climber. Leaves are never injured by insects or weather. 3. t. A. $20 \mathrm{ft}$. Price: Plst., 10c.

\section{Japanese Kudzu Vine}

From Seed; Hardy and a Rapid Grower

The beautiful new Ornamental and Rapid Climbing Vine which we offered last season met with such universal praise that we have no hesitancy in urging our customers everywhere to try it. See illustration. It is much better to grow these from seed in this locality, as the imported roots do not thrive, as they are in transit from Japan too long and seems to injure them a great deal. Seed, per pkt., 10c.

\section{Maurandia}

FINE MIXED-Suitable either for house or garden culture. TP. $10 \mathrm{ft}$. Price: Pkt., 10c.

\section{Mina}

LOBATA-Half hardy Mexican climbing annual. The buds are at first of a vivid red, but turn to orangeyellow before they open, and when fully expanded the flowers are of a creamy-white shade. They are freely produced from the base to the summit of the plant, which attains a height of from 18 to $20 \mathrm{ft}$. Seed should be sown early. HA. Pkt., 10c. 


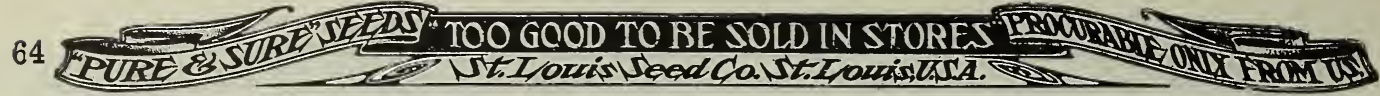

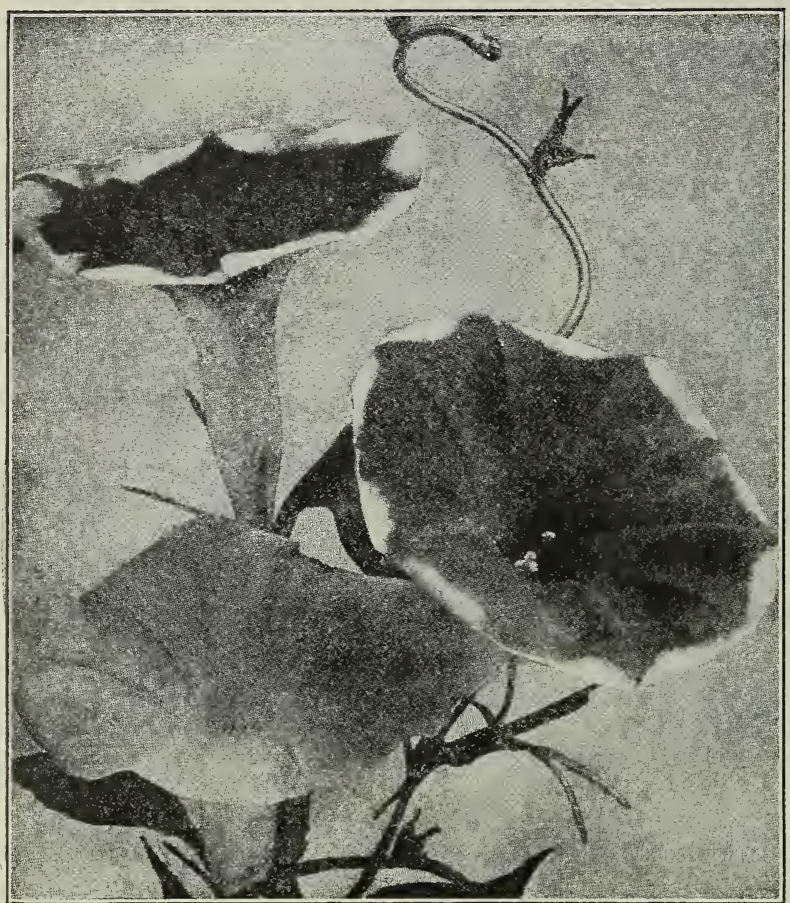

New Japanese Ipomea

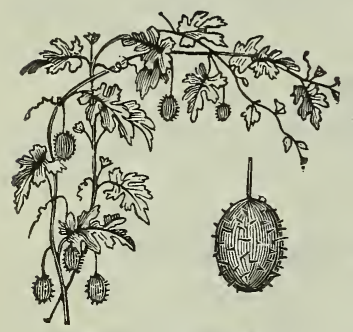

Wild Cucumber

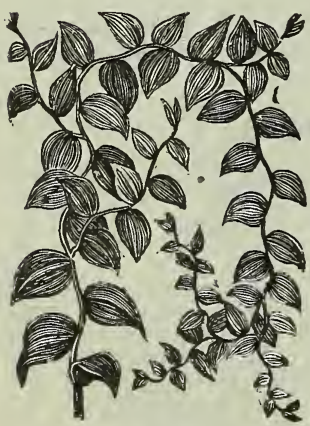

Smilax

\section{Passiflora}

\section{(Passion Vine)}

COER ULEA - Very popular for window decoration or sunny locations in the garden. Blue. 2-3. hh. P. 10 feet. Price: Pkt., 5e.

\section{Perennial Peas}

LATHYRUS LATIFOLIUS - If you have a fence or a stump to cover with a vine that makes lots of growth, bears attractive, large clusters of flowers, and never dies, but increases in size every year, plant this h. $P$.

Pink, white, mixed, each variety, Pkt., 10e each.

\section{Thunbergia}

MIXED (Blackeyed Susan)Handsome foliage and flowers Used for a screen or basket. 1-2 hh. A. 6 ft. Price: Pkt., se.

\section{Wild Cucumber}

A rapid climber and free bloomer. Very popular for small city yards. We highly recommend it for porches, fences or outbuildings. Price: Pkt., 5e.

\section{Smilax}

Beautiful greenhouse climbers 2-3 g. P. Price: Pkt., 5e.

\section{CLIMBERS - Continued}

\section{Morning Glories}

NEW JAPANESE IMPERIAL-This exquisite new Morning Glory is without doubt the finest new specie ever offered. So rich and beautiful are its gorgeous markings of handsome blotched petals that it cannot be compared with the ordinary Japanese Morning Glory. The flowers are of enormous size, and the vines of a beautiful clinging nature. Price: Pkt., 10e; oz., 20c.

RUBRO COERULEA (Heavenly Blue)Beautiful, large flowers; light blue, one of the most rapid climbers. Price: Pkt. 10e; oz., 35e.

SETOSA (Brazilian Morning Glory)Bears enormous rosy flowers with a pink satiny s.tar. Seed pods add a great deal to its attractiveness. Price: Pkt., 5e; oz., 30e.

Fine Mixed-All colors, Pkt.,5c; oz., $10 \mathrm{c}$.

\section{Moonflower}

WHITE LARGE FLOWERING - The most rapid growing of all annual twining vines. Grows to a height of 50 feet or or more in favorable seasons. t. A. Price: Pkt., 10e; oz., 35e.

BLUE (Impomoea Bona Nox)-Beautiful large violet flowers. Price: Pkt., 5e; oz., 20e.

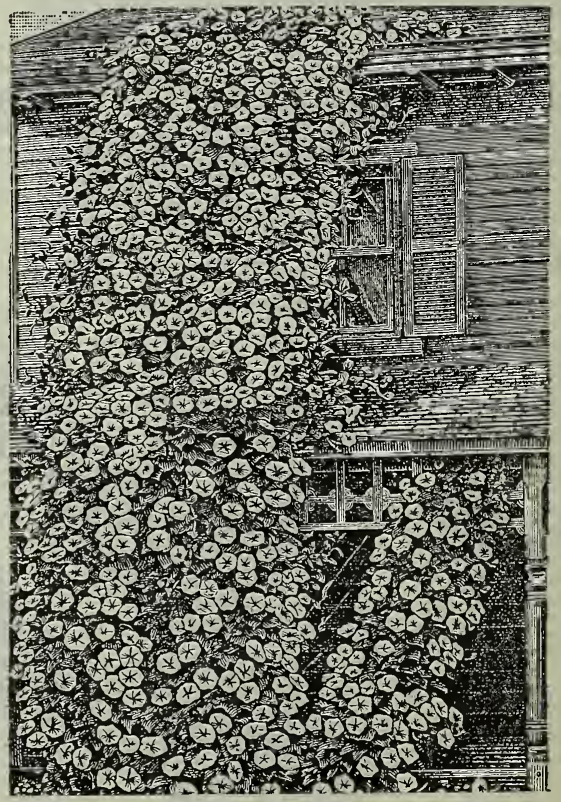

Moon Flower 


\section{Sweet Peas}

\section{Grand "Orchid-Flowered" "Countess Spencer" Type}

\section{True Countess Spencer}

The coloring is a soft rose-pink, which deepens at the outer edges and becomes still richer or more heavily suffused in cool weather. In size, form and coloring, COUNTESS SPENCER is simply exquisite. The plant is a strong vigorous grower, and the large flowers are borne three and four upon long stiff stems. Price: Pkt., כc; oz., 10c; 1/4 lb., 30c.

\section{Helen Lewis}

This superb variety received the Certificate of the National Sweet Pea Society of England. It is a grand gigantic orchid-flowered seedling of Countess Spencer. The orange-rose wings roll and fold; the standard is reflexed, showing the distinctly fluted effect, and is of an intense rich crimson orange. The blooms are truly of a gigantic size-the ruffled standard measuring 2 inches across. Very brilliant. Price: Pkt., 5c; oz., 10c; $1 / 4$ lb., 30c.

\section{Horace Wright}

Standard dark bronzy claret, stiffly erect; wings dark rich purple-violet. Per pkt., 5e; oz., 10c; 1/4 1b., 30c.

\section{Henry Eckford}

The flowers are self-colored in a bright soft fiaming orange, deepening slightly in the center. To secure the finest color effect the flowers should be cut as soon as opened and allowed to develop in water in a cool room, as they will fade under the hot sunshine; or an even better plan is to cover the blooming plants' with cheese cloth. Price: Pkt., 5c; oz., 10c; $1 / 4$ lb., $25 c$

\section{Phenomenal}

\section{Spencer Type}

Very large flower of hooded and wavy form. The lower blossom on the stem is often double. The color is white, suffused with rosy lavender, which grows deeper toward the edges. Price: Pkt. 5c; oz., 10c; $1 / 4$ lb., 30c.

\section{Mrs. Walter Wright}

\section{Spencer Type}

The flowers are self-colored, of a pinkish-cream tint when first opening, changing to mauve and then to a reddish violet. A very handsome and effective, one of the best varieties. Price: Pkt., 10c; oz., 20e; 1/4 lb., 75e.

\section{Blanche Ferry}

Spencer Type

The popular pink and white; always reliable fine cut flower variety. Price: Pkt., 10c; oz., 20c; $1 / 1$ 1b., 50c.

\section{Queen of Spain}

The flowers, of fair size, are self-colored in a delicate peach-blossom pink with slight apricot tinge. The color effect is a self buff-pink, resembling that of Countess of Latham, but is lighter and comes entirely true from seed. Price: pkt., 5c; oz., 10c; $1 / 4$ 1b., 25c.

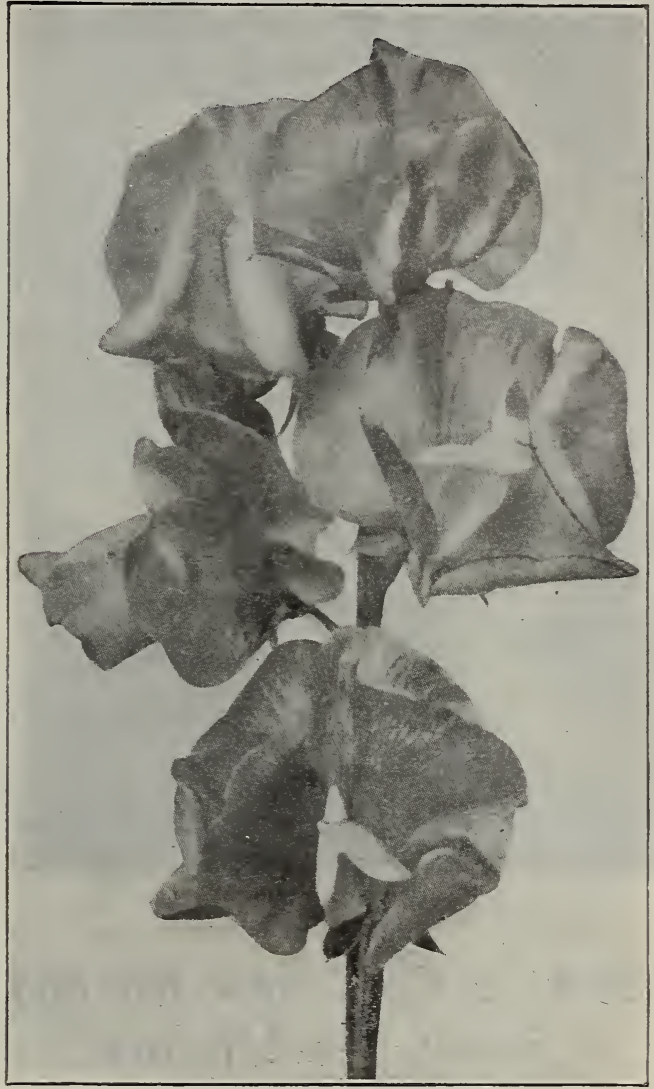

True Countess Spencer

\section{White Spencer}

Produces in the greatest profusion pure white flowers of large size. It is white-seeded and the flowers-of the spencer type-extremely beautiful. The bold standard is crinkled and fluted; the wavy wings are so folded that the keel is' almost hidden. The standard measures from one and three-quarters to two inches across by one and three-eighths to one and five-eighths inches in depth. The wings are fully an inch wide and nearly as deep as the standard. The flowers are borne three and four to the stem and are uniformly well placed. The stems are extra strong and measure froni twelve to fifteen inches in length. The vines are most vigorous in growth, with heavy foliage, and attain a height of ten to twelve feet. They are almost completely covered with bloom, while the flowers retain their large size throughout the season. Price: Pkt., 5e; oz., 10e; $1 / 4$ lb., 30c.

\section{Queen Alexandra}

This is an intense scarlet self of grand texturea bold expanded flower of finest form. It is very free flowering and the flowers are of giant size with long strong stems. This grand flower does not buru in the sun, and might be described briefly as a larger, finer "fadeless" "Scarlet Gem." Price: Pkt.. бe: Oz., 10c; $1 / 4$ 1b., 25e. 


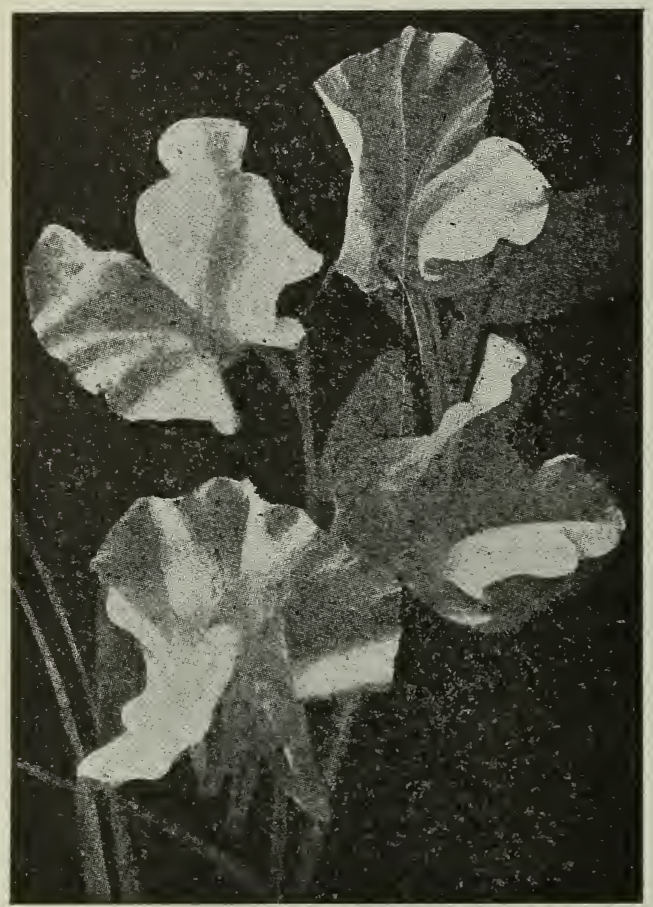

Nora Unwin

\section{St. L. S. Co.'s New Novelty Sweet Pea Mixture}

Of Spencer, Unwin and Grandiflora Types.

\section{A BEAUTIFUL SWEET PEA GARDEN}

Those Who Appreciate Lovely Sweet Peas Will Be Delighted in These

In offering you this mixture of all the latest introductions, we do so with the knowledge that every Sweet Pea lover will be enthusiastic at the opportunity of producing an assortment of colorings at a nominal cost such as could not be secured in any other way. 'Each and every variety will be found the finest and choicest of all the large fancy flowering sorts in the Sweet Pea world. Prices: Pkt., 10c; oz., 15c; $1 / 4$ lb., 35c.

\section{Sweet Pea Collection}

$$
\text { - of- }
$$

Eleven (11) Big Packets; each packet a separate color of the best varieties. This enables you to have all colors which you can plant as you wish. A circular is enclosed with this collection on how to plant and grow them. Price, 25c.

\section{SWEET PEAS}

New Waved Sweet Peas

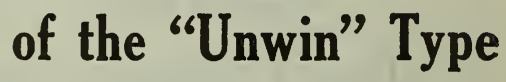

Although of distinct origin Gladys Unwin is nearly of the same type as the Countess Spencer, but the flowers are not so large. These seeding varieties resemble the parent and generally come uniformly waved and fluted.

\section{Gladys Unwin}

A bold flower, with striking upright standard which is crinkled and waved; broad wings. Of a lovely light pink color. Price: Pkt., 5c; oz., 10c; $1 / 4$ 1b., 25c.

\section{E. J. Castle}

The color is a rich carmine-rose with salmon shading in the standard. This rich color with the boid wavy standard of the Unwin type makes' a most striking effect, especially in artificial light. Price: Pkt., 5c; oz., 10c; $1 / 4$ 1b., 25c.

\section{Phyllis Unwin}

The flowers are larger in size than the original Gladys Unwin and similarly crinkled wavy standard with broad wings. The long stout stems carry three and four flowers each; of a beautiful rose color throughout. Comes' perfectly true. Price: Pkt., 5e; oz., 10c; $1 / 4$ lb., 25e.

\section{Nora Unwin}

A very beautiful pure white variety, finely waved or fluted. The flowers are borne generally three on a stem, and while not so boldly spreading as are the flowers of White spencer, the standard is distinctly erect and the wings curve in closer to the keel. Of good substance and a finely effective flower, it has been pronounced "the next best white" to White Spencer and comes true from seed. Price: Pkt., 10c; oz., 20c; $1 / 4$ lb., 50c.

\section{Florists' Lavender}

Flowers very large, well formed and of a beautiful shade. The long, stiff stems make it a leader for cut flowers. Vines are of vigorous and robust growth. Price: Pkt., 5e; oz., 10c; 1/4 1b., 25e.

\section{Mrs. Alfred Watkins}

Flowers of large size, beautifully formed and widely spreading, with the wavy or crinkled effect so much admired. Both standard and wings are a clear pink color which is suffused over the entire fiower, but rather deeper and heavier at the outer. edges. Price: Pkt., 5c; oz., 10c; 1/4 1b., 25c.

\section{Helen Pierce}

The color is very bright blue, mottled on pure white. It does not show any suggestion of stripe but is uniformly marbled or mottled. Of good size and perfect shell shape. Per pkt., se; oz., 10c; $1 / 4$ lb., 25c. 


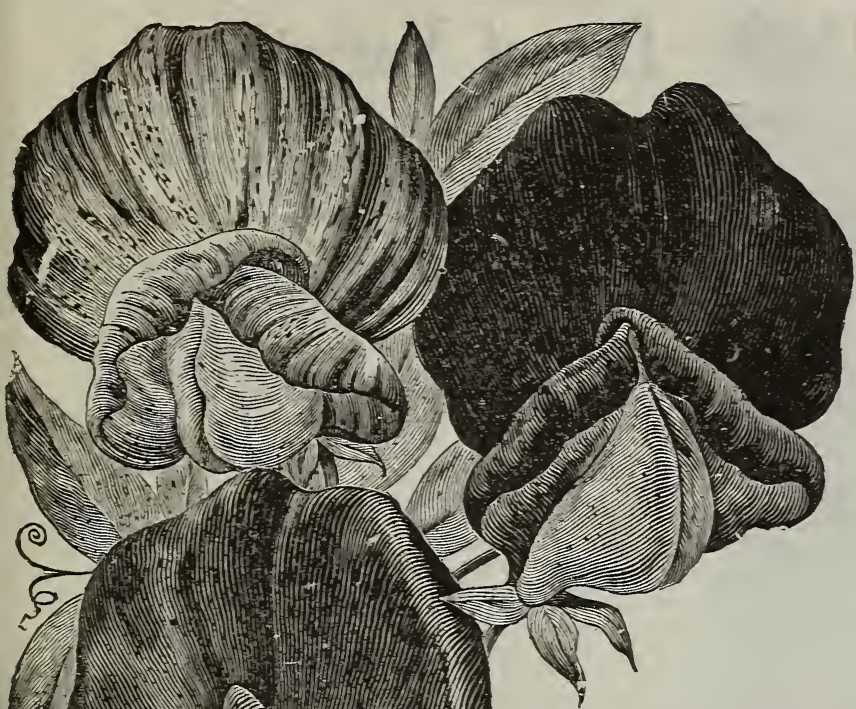

\section{Sweet Peas}

\section{Standard Varieties}

There are now in commerce, including the New Orchid-flowered type, about 300 varieties of Sweet Peas, with $n \in w$ sorts being added every year. Every year our list is carefully revised, with a view to keeping it strictly upto-date; and while it seems hard to dispense with some of the once popular kinds, yet it must be done to keep up with the march of progress. See pages 65-66 for newest sorts.

APPLE BLOSSOM-Color of Apple Blossoms. Pkt., כe; oz., 10c; $1 / 4$ lb., 20c.

AURORA - Wh it e, magnificently flaked and striped orange. Pkt., כe; oz., 10e; $1 / 4$ lb., 20c.

BLAYCHE BURPEE-Of the best white. Pkt., 5c; oz., 10c; $1 / 41 b ., 20 c$. BLANCHE FERRY-The popular pink and white variety. Pkt., כe; oz., 10e; $1 / 4$ lb., 20c.

COUNTESS OF RADOR, IMPROVED-Pure light lavender; wings dark mauve. Pkt., ic; oz., 10c; 1/4 Ib., 20e.

DOROTHY ECKFORD-Fine pure white large flowers. Pkt., 5c; oz., 10e; $1 / 4$ 1b., 20c.

KATHERINE TRACY-Bright pink; excellent. Pkt., 5e; oz., 10e; 1/4 1b., 20c.

KING EDWARD VII-A true giant flowering variety, with strong stems and growth. In fact the best scarlet in existence. Pkt., Jc; oz., 10c; $1 / 4$ lb., 20c.

LAIIY GRISEL HAMILTON-Light lavender blue. Pkt., 5c; oz., 10c; $1 / 4$ lb., 20e.

IRS. JOS. CHAMBERLAIN-Ground color is a clear silvery white, brightly striped soft rosy pink. Pkt., 5c; oz., 10c; 1/4 lb., 20c.

MRS. GEORGE HIGGINSON, JR.-Light blue. Pkt., כe; 0z., 10c; 1/4 lb., $20 \mathrm{c}$.

OTHELLO-Deep maroon. Elegant for bouquets. Pkt., 5c; oz., 10c; 1/4

1b., 20c.

PRINCE DF W.ALES-Bright rose pink. Plkt., 5c; oz., 10c; $1 / 4$ lb., 20c.

THE HON. MRS. KENYON-Primrose yellow. Pkt., 5e; oz., 10c; 1/4 1b., 20c.

\section{Forcing Varieties}

CHRISTMAS WHITE-Price: Pkt., 5c; oz., 15e; $1 / 4$ lb., 40c.

CHRISTIAS PINK-Price: Pkt., 5e; oz., 15e; 1/4 1b., 40c.

MRS. ALEXANDER WALLACE (Lavender)-Pkt., 10e; oz., 20c; 1/1 Ib., $75 \mathrm{c}$.

MONT BLANC (White)-Pkt., 5c; oz., 10c; 1/4 1b., 20c.

EARLIEST OF ALL (Pink and Thite)-Pkt., 5c; oz., 10c; 1/4 1b., 20 c. EXIRA EARLY BLANCHE FERRY (Pink and White)-Pkt., כe; oz., 10e: $1 / 4$ lb., 20c.

St. L. S. Co.'s Superb Mixture.

\section{Eckford's New Seedlings Mixed}

Composed entirely of Eckford's finest largeflowered varieties. Pkt., 5c; oz., 10c; 1/4 1b., 20c; 1b., 60c.

\section{St. Louis Seed Co.'s Superb Mixed}

This strain embraces more fine varieties than are found in Eckford's New Seedlings Mixed, and is superior. Oz., 5c; $1 / 4$ lb., 15e; lb., 50c.

\section{Cupid Varieties}

Compact, dwarf plants, 7-in. high, covering a circumference of about 18 in., covering the ground like verbenas. Fine for low beds and pot culture. MIXED-Different colors. Pkt., 5e; oz., 10e; 1/4 1b., 20e.

\section{Bush Varieties}

These grow in perfect bush form, 16 to 18 inches high. They require no trellis when grown in hedge form, but when grown as individual bushes the support of light crossed sticks should be given. They freely produce flowers of large size. MIXEDPkt., 5c; oz., 10c; $1 / 4$ lb., 25c. 


\section{NASTURTIUMS - Dwarf Varieties}

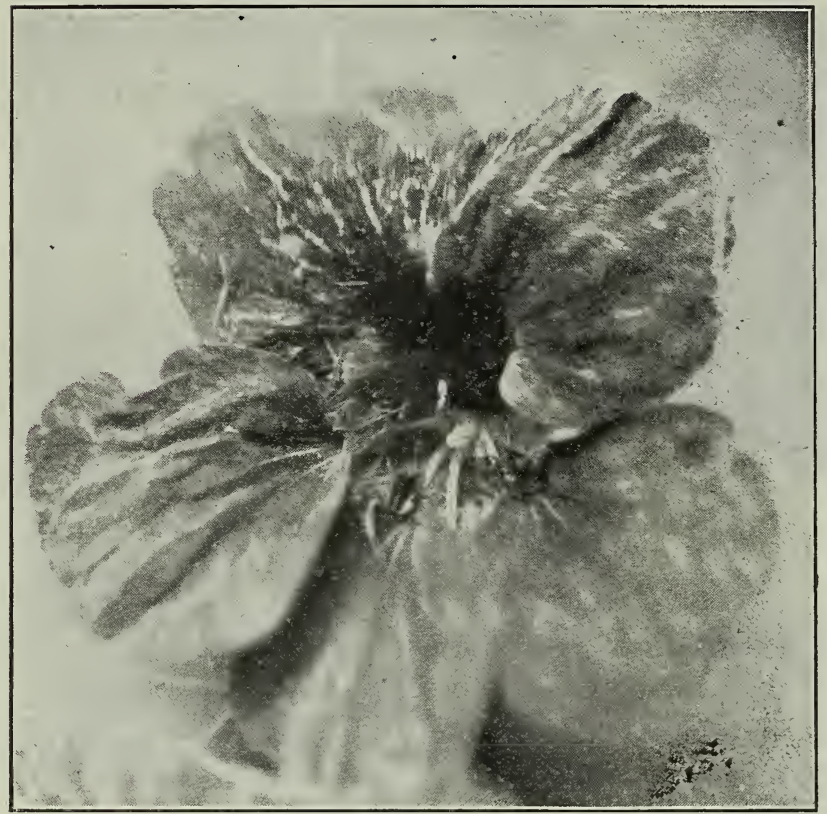

Shaw's Garden Hybrids

For ease of culture, duration of bloom, brilliancy of coloring, and general excellence, nothing excels Nasturtiums. All they need is a moderately good soil in a well drained, sunny position, and from within a few weeks from the time they are sown until hard frost comes there is an erdless profusion of their gorgeous blos'soms. For cut flowers the tall varieties furnish the largest supply. Do not sow too early.

Dwarf forms of Nasturtiums are especially adapted for beds' or borders.

AURORA-Lovely and distinct; salmonrose mottled blush white, garnet blotches. Price: Pkt., 5c; oz., 15c.

BEAUTY-Beautiful yellow and scarlet. Price: Pkt., 5e; oz., 15c.

CHAMELEON' (New French)-P'roduces flowers of many different colors on the same plant. A magnificent variety. Price: Pkt., 5c; oz., 15c.

CLOTH OF GOLD-Golden yellow foliage, light scarlet flowers. Very effective. Price: Pkt., 5e; oz., 15c.

EMPRESS OF INDIA-Brilliant crimson, dark foliage. Very rich. Price: Pkt., 5e; oz., 15c.

KING THEODORE-Dark scarlet maroon, dark foliage. Price: Pkt, 5c; oz. $15 \mathrm{c}$

IUUBY KING-Ruby red dark leaves. Price: Pkt., 5c; oz., 15c.

LADY BIRD-Orange yellow, red s'pots. Price: Pkt., 5c; oz., 15c.

VESUVIUS - Beautiful salmon rose. Price: Pkt. 5c; oz;

KING OF TOM THUMBS-One of the finest dwarf scarlet varieties. Price: Pkt., 5e; oz., 15c.

PRINCE HENRY-A handsome yellow marbled scarlet specie, that is fast attaining popularity everywhere. Price: Pkt., 5c; oz., 15e.

\section{Shaw's Garden Hybrids}

\section{DWARF NASTURTIUMS}

The prettiest strain of Dwarf Nasturtiums. Worth ten times the price of the ordinary mixed. There's' really no comparison in the beauty and color of the flowers. They are larger, produced in greater profusion, with longer stems, and in colors much more varied in the hundreds of beautiful shades not found in any other mixture.

We are confident that this will become the only Nasturtium mixture that will be sown by all our customers. It cannot be beat. P'kt., 10c; oz., 15c; $1 / 4$ lb., 50c; 1 lb., \$1.50.

\section{ST. L. S. CO.'S}

\section{Gilt Edge Nasturtium}

\section{MIXTURE}

We have spared neither time nor expense in producing the finest strains of the dwarf varieties to add to our new "Gilt Edge" Mixture, which yields an endless collection of colorings of the most delicate hue. It matters not whether you have room for a single bed or a flower garden, it will pay you to give preference to this mixture above all other flowers. Price: Pkt., 10c; oz., 20c; 1/4 lb., 50c; 1 lb., $\$ 1.75$.

ST. L. S. CO.'S DWARF MIXTURE-In offering you this celebrated mixture we do so with the knowledge that after you have once tried it you will plant no other. Our mixture contains all the good standard sorts and colors. Price: Pkt., 5c; oz., 10c; $1 / 4$ lb., 25c; 1 lb., 75c.

SPECIAL OFFER

Collection 8 Large Packets, 25c Each Packet a Separate Color. All Dwarf Varieties.

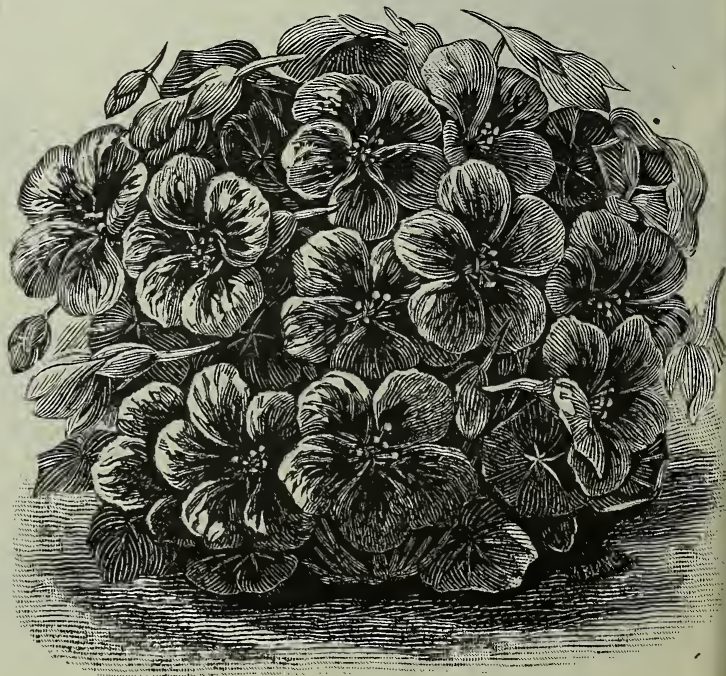

Nasturtiums, Gilt Edge Mixture 


\section{NASTURTIUMS Climbing Varieties}

\section{Hybrids of Mme. Gunther}

THE RICHEST STRAIN OF ALL. These new Hybrids make a strong growth, climbing about six feet and covered from spring to fall with large substantial flowers of the most brilliant shades. They are remarkable for their wide range of color, embracing many unknown shades: The foliage is generally dark and contrasts effectively with the rich colors of the Howers. Pkt., 5e; oz., 15e; 2 oz., 25e; 1/4 lb., 40e; 1b., \$1.25.

SUNLIGHT-Flowers of superb size, ranging from primrose to deep orange, blotched crimson in the throat and on the upper petals. Price: Pkt., 5e; oz., 15c.

GOLDEN-LEAVED SCARLET - Price P'kt., 5e; oz., 15e.

VESUVIUS-An exquisite shade of salmon. Price: Pkt., 5e; oz., 15e.

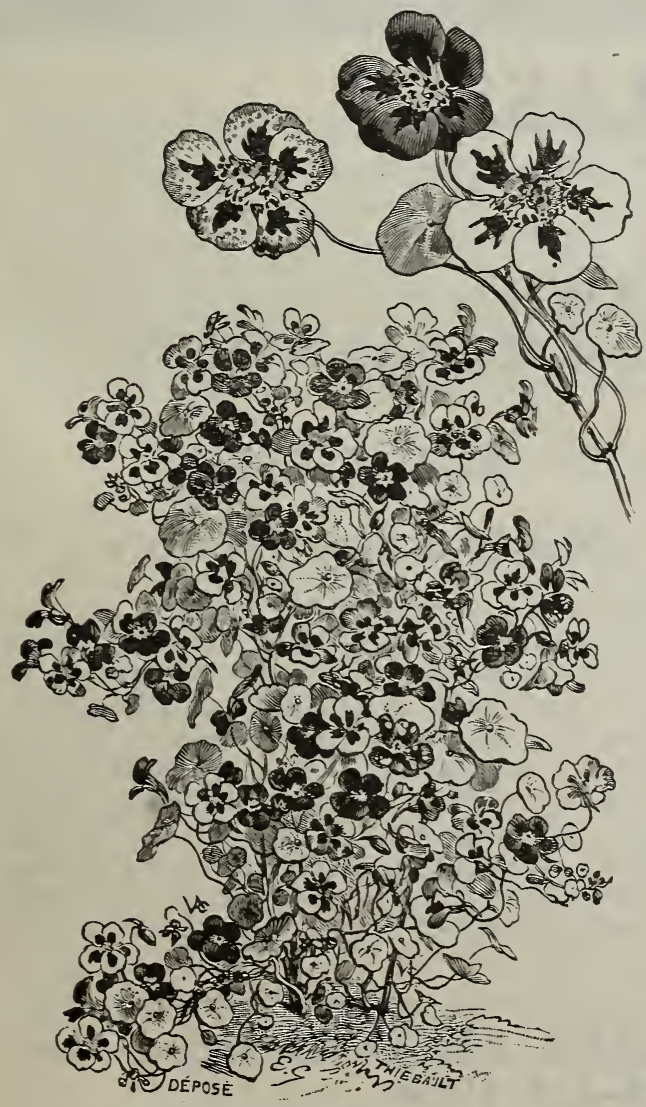

Lobb's Fine Mixed

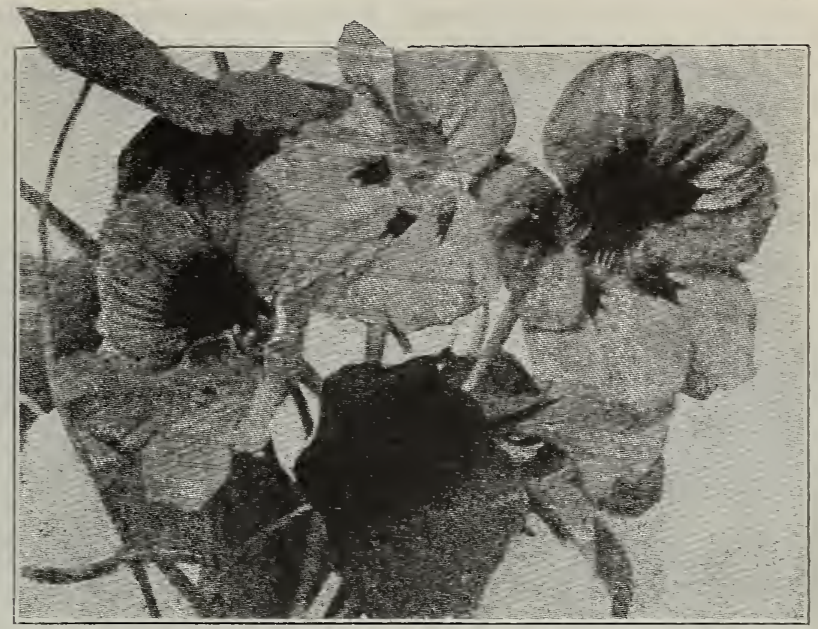

PEARL-Very large; buff colored, heavily blotched rosy salmon, the three upper petals penciled with crimson. Price: Pkt., 5e; oz., 15e.

ATROPURPUREA-One of the finest dark colored Nasturtiums. Price: Pkt., 5c; oz., 15e.

HEMISPHEIRICUM-Of a beautiful orange color. Price: Pkt., 5e; oz., 15e.

KING THEODORE-The darkest of the dark-leaved variety. Very showy. Price: Pkt., 5e; oz., 15c.

SCHULZI-Similar to the above, only not quite so dark in color. P'rice: Pkt., 5c; oz., 15e.

TALL MIXED NASTURTIUMS-A mixture which is considered the best assortment grown. Price: Pkt. 5e; oz., 10c; $1 / 4$ lb., 20c; lb., 60c.

\section{Lobb's Climbing Sorts}

This class is remarkable for the intensely brilliant colors of its flowers, which are a trifle smaller than those of other sorts. In moderately rich soil they climb high and bloom brilliantly. Average height, 6 feet.

ASA GRAY - A beautiful yellow and white flowe: a favorite everywhere. Price: Pkt., 5c; oz., 15c.

CROWN PRINCE OF PRUSSIA-Similar to the above, orily a beautiful blood red. Price: Pkt., 5c; oz., 15c.

IIRGARET-Also called PRINCE VICTORIA LOUISE-A very pretty yellow and white variety. Price: P'kt., 5e; oz., 15c.

REGINA-The favorite salmon-colored variety. Price: Pkt., 5e; oz., 15c.

BLACK PRINCE-One of the handsomest black climbers. Price: Pkt., 5e; oz., 15c.

LOBB'S MIXED-Are unexcelled for covering fences and unsightly places; are especially free flowering. with very intense colorings. Very rapid growing form of Nasturtiums. Price: Pkt., 5c; oz., 15e; 1/4 lb., 35c; 1 lb., \$1.00.

\section{Tall "Ivy-Leaved" Nasturtiums}

The plants' are of running growth, with star-like pointed leaves of rich green, veined with white, so that the young shoots, where the leaves are set quite closely together, have a marked resemblance to the foliage of the hardy English Ivy. The flowers are of medium size and of most distinct form. Assorted colors. Price: P'kt., 10c; oz., 25e; 1/4 lb., 75e. 

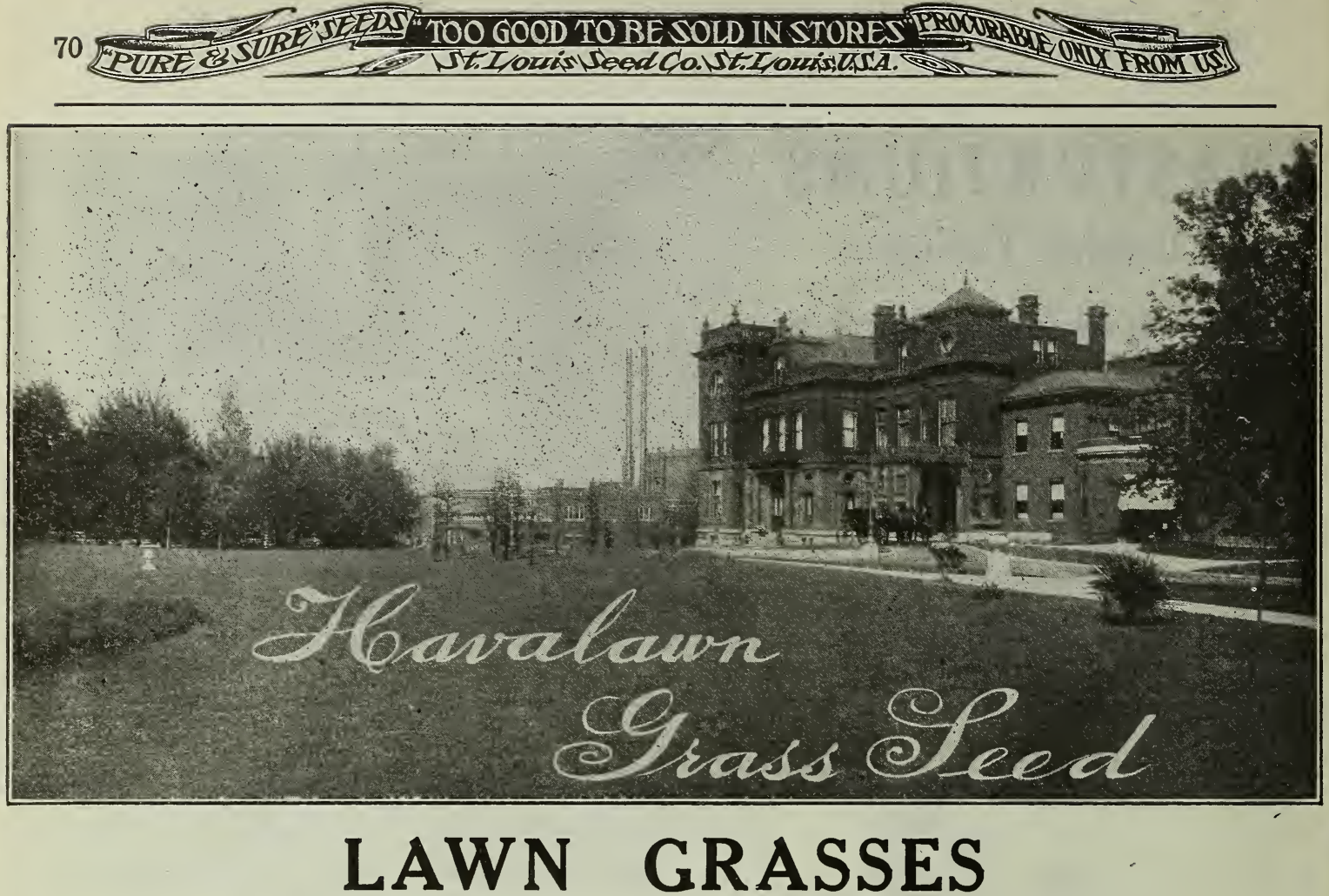

Especially Adapted for This Locality and Will Insure a Fine Velvety Lawn

\section{"If you want a LAWN That IS a LAWN Sow HAVALAW N"}

\section{Havalawn}

(Name registered in U. S. Patent Office.)

Is procurable only from us. Every package bears our green label. No other is genuine, and we will prosecute all infringements.

\section{Havalawn Mixture}

Will insure a beautiful, compact evergreen sod on any lawn where the essential requirements of grass culture have been complied with. Its component parts are the grasses particularly adapted to lawns and door yards. It is composed of the best thriving varieties, together with the best known creeping or sod-forming sorts. Timothy and orchard gras's are wholly excluded on account of their coarse leaves, and only finest sorts are used. Full provision is made for a succession of growth, so that there shall be no break in the richness of the verdure from spring until autumn, and experience proves that Havalawn Grass Mixture is now perfect. Nothing better can be purchased on the American market, no matter what claims may be advanced by other seedsmen. Price: Per 1b., 30c; half bu. (7 lbs.), \$2.00; bu. (14 lbs.), \$4.00.

\section{St. L. S. Co.'s}

\section{Shady Lawn Mixture}

This mixture is intended for all situations that are in partial or complete shade, and will be found invaluable on grounds lying under the shadows of trees or buildings. In preparing such places for the reception of grass seeds it is well to use airslaked lime quite liberally. This mixture is a combination of fine dwarf-growing, evergreen varieties of grass, which grow naturally in the woods or in shaded spots. They are mixed in proper proportions to make a fine lawn under shade trees. Sow seed thickly. Price: Per lb., 30c; half bu. (7 lbs.), \$2.00; bu. (14 lbs.), \$4.00.

\section{Our Famous HAVALAWN GRASS SEED Awarded the L. P. Exposition Medal 1904}


LAWN GRASS-Cont'd

\section{Good Result Mixture}

This is intended for back yards, large playgrounds, etc., that are not intended to be kept cut as closely as other front lawns, and where grass is wanted quick to cover unsightly places; also for tenants who do not intend to stay long on the premises, yet want a good grass. We would advise setting the lawn mower as high as it will go in cutting this grass, and not water often, but when you do, do it in earnest, or else keep the water off. This rule should apply to all lawn grasses, Watering often burns out the grass more than you may think. This grass mixture will give value received for your time and money spent and will enable those who don't want to spend much on the lawn a chance to have plenty of green grass.

We are anxious to see every city lot covered with grass, instead of being covered with rubbish, tin cans, brush, ashes, etc. We make this mixture so it is within the reach of all. No excuse now for not having a lawn, if price has interfered before. Price: Lb., 20c; 2 lbs., 35c; half bu. (7 lbs.), \$1.15; bu. (14 lbs.),

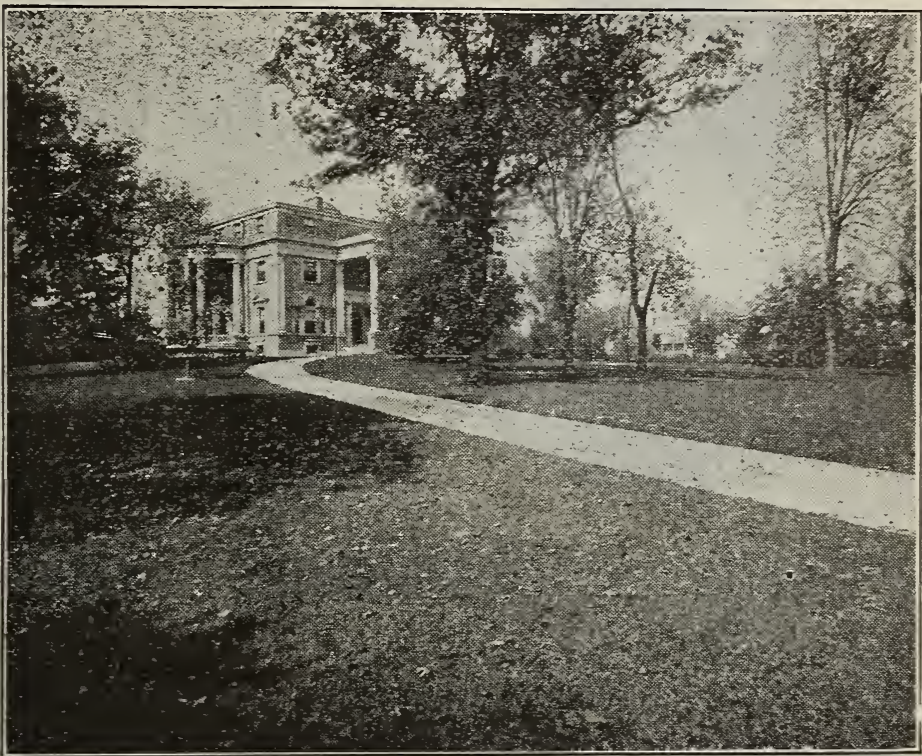

$\$ 2.00$

\section{Fancy Kentucky Blue Grass}

So widely advertised as an ideal lawn grass, it has merits and demerits. Where Blue Grass thrives it eventually makes a good lawn, but it is slow to thicken up, requiring not less than two years to form a good sward, and does not hold its color in hot weather; it will not thrive on acid soils, and a large proportion of soils in the lower altitudes, especially in the coast states, are inclined to acidity. Kentucky Blue Grass is quite extensively used for lawns on the Pacific Coast and on the limestone soils of Kentucky, etc., but the results of this or any one grass in no way compare with the beauty and fine velvety texture of lawns made with an intelligently blended mixture of grasses of neat, close, interweaving growth, such as compose the "Havalawn" Lawn Grass mixture; and besides, the latter will make a thick, clos'e turf in a few weeks' time. Price: Lb., 30c; half bu. (7 lbs.), \$2.00; bu. (14 ibs.), \$3.50.

\section{White Clover}

Valuable for the lawn with other grasses; helps to shade same and keep the soil from washing out. Price: Per lb., 40c.

\section{FORMATION OF LAWNS TO BE SOWN}

The ground should be thoroughly drained and well prepared. The soil ought not to be too rich, as a rapid growth is not wanted in the gras'ses of a lawn: but the surface should be as much alike in quality as possible and thoroughly pulverized. After sowing, the ground should be rolled in order to press the seed firmly into the soil. The proper time to sow grass seed depends, of course, upon the latitude. In this vicinity from early spring to hot weather. Seed may also be sown in the fall, provided it is done early enough to secure a good, strong growth before winter sets in. The sowing should be done when the ground is moist, or before an expected rain, and a subsequent rolling is always advisable. As to weeds in newly made lawns, it may not be generally known, but many weed seeds actually lie dormant in the ground for six or seven years and will germinate and make their appearance when the soil is turned up. It requires at least $1 \mathrm{lb}$. of seed to every 200 square feet of ground, not already seeded, to give best results.

Rolling-As soon as the frost is out of the ground in the spring, the land shold be gone over with a heavy roller. Winter frosts loosen the soil, and rolling is necessary to compress it again. If grass seed is to be sown, this should be done first and the rolling immediately afterward. Roll frequently.

Mowing-All turf-forming grasses are improved. both in vigor of root-growth and in fineness of texture by frequent mowings. It is imposisible to say just how often the grass should be mown, as that depends upon the rate at which it grows. Too close cutting should be guarded against, however, especially during the hot summer months, when the roots require some top growth to protect them from the burning sun. A good top growth is also necessary to protect the roots from severe winter frosts.

To Grass a Bank or Terrace-For each square rod, take a pound of lawn-grass seed, and mix it thoroughly with 6 cubic feet of good, dry garden loam; place in. a tub, and add liquid manure, diluted with about two-thirds of water, so as to bring the whole to the consistency of mortar. The slope must be made perfectly smooth, and then well watered, after which the paste should be applied. 


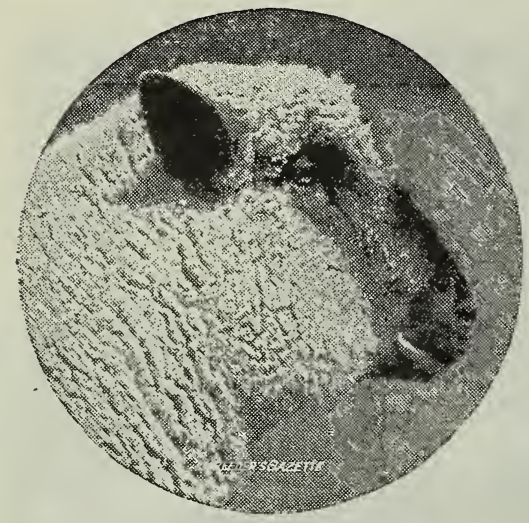

\section{Fertilizers}

\section{For Lawn, Garden, Field and House Plants}

A Necessity to All Growing Plants.

The farms of our land were never in such need of fertilizing as they are today. The Government Experiment Stations have proven that with the use of fertilizer you can raise much larger and finer crops, and without drawing on the land for all its nutriment. Report shows that the Western States are "waking up" and that there has been from 500 to 1000 per cent more increase in different States' in the past year in the use of fertilizers. Eastern farmers never think of sowing wheat and grasses without sowing fertilizer also. and our Western customers will soon do the same. The proper time to fertilize in St. Louis latitude is September for fall sowing and March for spring sowing.
Here is a Fertilizer that will satisfy those who are skeptical as to the use of Commercial Fer tilizers-

First-Because seeing is believing.

Second-Because you can see what it is.

Third-Because it adds humas to the soil.

Fourth-Becaus'e it nourishes plant life.

Fifth-Because it is pure; contains no weed seeds.

Sixth-Because it is easily applied, without dangering the plants in the least.

All these points are combined in our brands of Pure Shredded Cattle Manure, Pulverized Hog Manure and P'ulverized Sheep Manure.

\section{Shredded Cattle Manure}

This is a high grade of Fertilizer that will fill a long-felt want, and prepared in such shape to be easily applied by any man or boy This, added to our Pulverized Sheep Manure, on lawns will make grass grow on most any soil. It has been tested thoroughly and found to contain just what we are all wanting. It is being used on a large scale among gardeners and farmers on all crops and they find it cheaper and better than any compost they can haul from city or barnyard on the farm. They never can get enough at the latter places. This new form will enable them to have plenty on hand to use at any time they need it. We know of gardeners buying carloads of it and our Hog Manure. A hint to the wise is sufficient. Price: 51 bs., 20c; 10 lbs., 35c; 25 lbs., 75c; 50 lbs'., \$1.15; 100 lbs., \$2.00; 500 lbs., at $\$ 1.75$, delivered in city. Ton and car lots at special quotations.

NITRA'TE OF SODA-95 to 98 per cent purity, $181 / 2$ to $19 \frac{1 / 2}{2}$ per cent ammonia. 100 lbs. to the acre. Price: 1 lb., 10c; 10 lbs., 75c; 50 lbs., \$3.25: 100 lbs., \$6.00.

\section{Pulverized Sheep Manure}

As a top dressing for lawns there is nothing better. Promotes a steady and rapid growth in the vegetable garden. For garden and field crops; 1 to 2 tons per acre, one-half before plowing, balance before harrowing. For top dressing use 1 ton per acre-fall or early spring. Price: 5 lbs., 20c; 10 lbs., 35c; 25 lbs., 75c; 50 lbs., \$1.15; 100 lbs., \$2.00; 500 lbs., at $\mathbf{\$ 1 . 7 5}$, delivered in this city.

\section{Pulverized Hog Manure}

Is without any doubt one of the most powerful fertilizers. It is especially adapted for garden use, as well as for all grain crops. Potatoes will pay big where this is used. It is prepared in such shape it can be drilled with any farm seed drill. It is free from all foul seeds and always ready to use. Why should you raise crops that fail to yield, because you could not get the kind of fertilizers you needed heretofore? But you can't say that now. The above three fertilizers are pure, and if you figure what it costs you to haul stable manure from the city you will find you can buy the above brands much cheaper and have all you want for your crops.

Ask us, when in our store (or come in and see us) about these, and look at samples and see for yourself. Try it and be convinced, as we are. Prices: 5 lbs., 20c; 10 lbs., 35c; 25 lbs., 75e; 50 lbs. \$1.15; 100 lbs., \$2.00. Ton and car lots at special quotations.

PURE BONE MEAL-Price: 5 lbs., 20c; 10 lbs., 35e; 25 lbs., 65e; 50 lbs., \$1.25; 100 lbs., \$2.00.

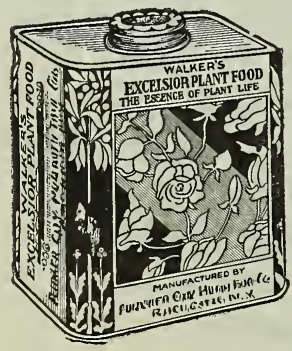

\section{St. L. S. Co.'s Excelsior Plant Food}

It will make weak plants strong and make healthy plants have brighter flowers and prolong the period of blooming. Price: Small size, 15c; large size, 25c.

\section{"Bonora"}

Nature's greatest Lawn and Plant Food. Used and endorsed by all the leading city parks in the United States, as well as all the botanical gardens throughout the land. It is the elixir of life and beauty to lawns, plants, flowers, vegetables, trees, etc., etc. A vitality pioducer par excellence. Price: 1/4-1b. can, makes 56 pints liquid, 25c; 1 - 1 b. can, makes 28 gallons liquid, 50c. 


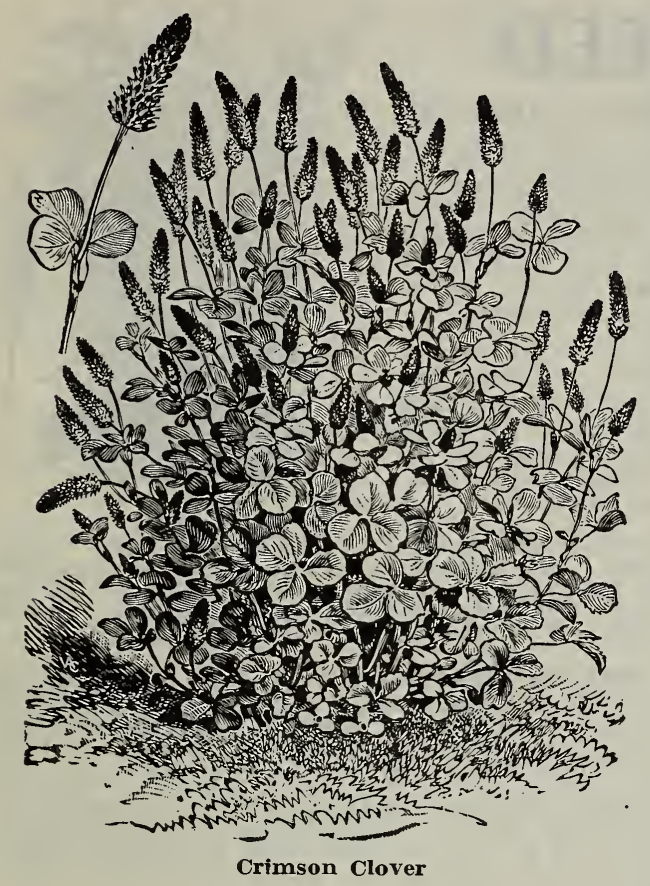

GENUINE TURKESTAN ALFALFA-Superior to the ordinary variety because of its greater ability to resist drought or stand higher temperatures. It possesses a very large root systen, and the general construction of the plant is to enable it to do this. Price: 1 lb., 25c; 10 1bs., \$2.40; bu., \$13.50; 100 lbs., $\$ 22.00$.

BOKHARA OR BEE CLOVER (Honey Sweet)Especially adapted to bees, the honey from it being as clear as a crystal. It is also recommended as a fertilizer, to be turned under when green. It is a very quick, vigorous grower. Price: 1 lb., 35e; 10 lbs., \$3.00.

JAPAN CLOVER (Lespezeda)-A low spreading perennial, very valuable for dry sandy land. Price: 1 lb., 45c; 10 lbs., \$3.50; 100 lbs., \$32.00.

WHITE CLOVER-A small, creeping, perennial variety, valuable for pasturage and lawns; its flowers are well liked by bees. Flourishes in a variety of soils, but prefers moist ground. Price: 1 lb., 40c; 10 lbs., \$3.50; 100 lbs., \$26.00.

\section{Clover Seed}

\section{PRICES ARE SUBJECT TO MARKET CHANGES}

\section{(60 Pounds Per Bushel.)}

RED CLOVER-The most practical of all Clovers, being used for hay and pasturage, as well as for enriching lands. Our strictly "Fancy Recleaned" grade cannot be surpassed by anyone. Price: 1 lb. 20c; bu., \$9.30; 100 lbs., \$16.00.

CRIMSON CLOVER (Scarlet Clover)-This is a highly valuable variety on account of its wonderful quick growth. Sown early in spring it furnishes a large crop of hay in May or June. It may be sown in midsummer or early fall as a catch crop for fine winter pasturage and for early spring, before other grasses or clovers are ready. For hay, it must be cut before coming into full bloom. Price: 1 lb., 20c; 10 lbs., \$1.25; bu., \$6.00.

ALSIKE OR SWEDISH CLOVER-A very hardy variety that succeeds on any kind of soil and resists extremes of heat and drought. It is usually planted in mixture with grass'es for pasturage and for hay; especially with timothy. It is excellent for bees. P'rice: 1 lb., 20c; bu., \$9.50; 100 lbs., $\$ 14.75$.

MAMMOTH CLOVER (Sapling)-Grows much taller and heavier than common Red Clover. Produces an enormous yield and is of high feeding quality. Price: Fancy recleaned, 1 lb., 25c; bu., \$10.25; 100 lbs., \$16.25.

ALFALFA CLOVER (Faney)-The King of Forage Plants-Alfalfa is the corner-stone upon which is being built the prosperity of wide areas' of our agricultural country-with its never-failing four to five crops of from six to twelve tons per acre; its great fattening qualities for horses, cattle, hogs, sheep and poultry, its drought-resisting qualities. After once being rooted, its perennity is more than two decades while some claim for it immortality. Price: 1 lb., 25c; 10 lbs., \$2.40; bu., \$12.75; 100 lbs., \$21.00.

\section{Permanent Pasture Mixtures}

PASTURE MIXTURE "A"-Good Moist Soils. Sow to fifteen pounds per acre. This is intended for the average soil. Use more seed where land is dryer. If stock does not keep down to six or ten inches use the mower to do so. Do not pasture too closely. This is well suited for "patching" your present pasture by disking or harrowing in. Price: 1 lb., 30c; 10 lbs., \$2.50; 100 lbs., \$22.00.

PASTURE MIXTURE "B"-Dry, Hilly Uplands. Sow fifteen to twenty pounds per acre. Recommended for rolling ground, or where stones or sand in soil demand drought-resisting varieties. Plow or disk in where possible, and on unplowed, stumpy or stony ground brush thoroughly. Price: 1 lb., 35c; 10 lbs., \$2.75; 100 lbs., \$24.00.

PASTURE MIX'TURE "C"-Shaded Pastures. Sow five to ten pounds per acre. This is especially planned to suit the woods, which is often waste except for its timber. Get the seed on and into the ground; do not leave on top of the leaves. The more open use the more seed. Price: 1 lb., 40c; 10 lbs., \$3.00; 100 lbs., \$27.00. 


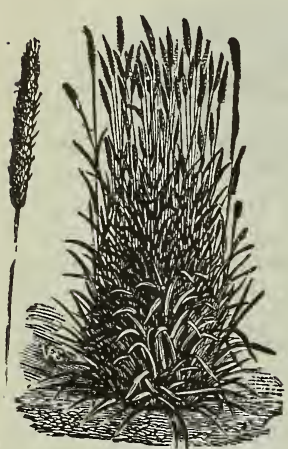

Timothy

\section{GRASS SEED}

(PRICES SUBJECT TO MARKET CHANGES)

TIMOTHY-(45 lbs. per bu.)-The best of all grasses for hay. It should be cut when in blossom, in June or July. It is preferable to sow in the fall, but we sell almost as much seed in the early spring and it is frequently sown then with equal success. Price: Fancy-Bu. \$4.50; 100 lbs., \$9.50. Choice-Per lb., 15c; bu., \$4.25; 100 lbs., \$9.10.

TALL MEADOW OAT GRASS-(14 lbs. per bu. $)$ This grass should be given the trial its merit deserves. It is a luxuriant grower for early and late permanent pasture. For hay it may be cut twice a year and for green soiling it may be cut four or five times in favorable seasons. Height, 2 to 4 feet. Price: 1 lb., 20c; 10 lbs., \$1.70; bu., \$2.25.

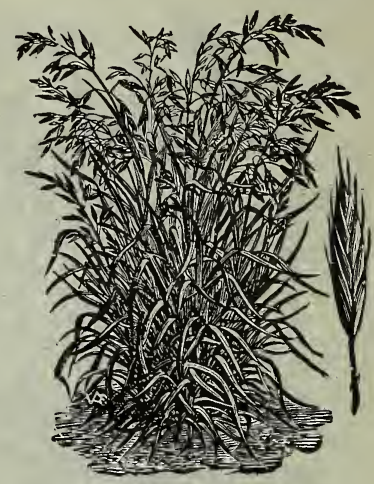

RED TOP - A very hardy native perennial grass, succeeding best on moist land. It accommodates itself to a variety of soils, however, even to quite dry situations, and stands our hot climate admirably. Fancy or solid seed-Price: 1 lb., 25c; 10 lbs., \$2.00; 100 lbs., \$14.50.

ENGLISH BLUE GRASS-(14 lbs. per bu. $)$ (Meadow Fescue)-A valuable pasture grass. Its long and tender leaves are much relished by all kinds of stock. Height 18 to 24 inches'. Price: 1 lb., 25c; 10 lbs., \$2.00; bu., \$2.50; 100 lbs., \$14.00.

ORCHARD GRASS (Rough Cock's Foot) (14 lbs. per bu.) -A rather coarse perennial grass that forms dense tufts, recommended for partially timbered soils of the central states. Flourishes best in the shade. Price: 1 lb., 25c; 10 lbs., \$2.25; bu., \$2.75; 100 lbs., \$16.00.

ENGLISH PERENNIAL RYE GRASS-(20 lbs. per bu.) - It is invaluable for permanent pastures, for hay if cut when in blossom. Price: 1 1b., 15c; bu., $\$ 1.90 ; 100$ lbs., \$8.00.

BERMUDA GRASS-Used extensively in the South for lawns, where other lawn grasses cannot be successfully grown. Sow seed in the spring. Price: 1 lb., 75c.

AWNLESS, OR SMOOTH BROME GRASS-(14 1bs. per bu.)-An erect perennial, 3 to 5 feet high. It is considered one of the best hay grasses, yielding a good return in the arid and silicious soil. It has passed the experimental stage, and our customers can sow it with an assurance of success, on account of its remarkable drought-resisting powers. Prices: 1 lb., 20c; bu., \$2.00; 100 lbs., \$10.50.

JOHNSON GRASS-(25 lbs. per bu. $)$-Extensively grown in the southern cities, where during the hottest and dries't months it yields large crops of hay. Sow from August to October, or in spring. Crop almost failure.

REED CANARY GRASS-This is also an excellent grass for a covering for wild game and for food, and is sown around spots similar to smart Weed seed and wild rice. Price: 1 lb., 45c; 10 lbs., \$3.50; 100 lbs., \$32.00.

SHEEP'S FESCUE-(14 1bs. per bu.)-Fescues are being appreciated wherever introduced. This variety deserves a place in the stock pastures. Price: 1 lb., 25e; bu., \$3.00.

HARD FESCUE-Smaller and less vigorous growth than Sheep's Fescue. It suits sandy or dry, hilly soils. It stands heat or cold and prolonged drought. Price: 1 lb., 25c; bu., \$3.00.

RED FESCUE-(14 lbs. per bu.)-For meadows or pastures on dry, hard or sandy soils. It is very hardy. Price: 1 lb., 30c; bu., \$3.75.

FOR LAWN GRASS-See pages 70-71.

\section{MILLETS (sons as o to bus}

All Field Seed Prices Subject to Change

\section{German or Golden}

It is a strong grower and will yield enormous crops of the finest hay, and should be cut before the seeds will harden. Can be sown late after some early crop and if sown early will mature in time for the ground to be plowed for wheat, and it leaves the ground in fine shape for this purpose. For hay, sow from May to August 1st. For grain, sow in drills not later than June 20 th. FancyPrice: 1 lb., 10c; 10 lbs., 55c; bu., \$1.75; 100 lbs., $\$ 3.25$.

\section{Hungarian}

Commonly called Hungarian Grass. A quick growing, valuable forage plant. May be sown at any time during the summer up to the middle of August. It has a long, slender head, and is darker in color than the German. Price: 1 lb., 10c; 10 lbs., 40c; bu., \$1.75; 100 lbs., \$3.25.

\section{Siberian}

More productive than the German or Golden and of superior quality. Is superseding all other varieties in some sections. Price: 1 lb., 10c; 10 lbs., 50c; bu., \$1.75; 100 lbs., \$3.25.

\section{Our Business Grows because Our Seeds Grow}




\section{Farm Seeds}

PRICES SUBJECT TO MARKET CHANGES. Dwarf Essex Rape

The demand for Dwarf Essex Rape is becoming so great that it is increasing many fold each year. It is easily grown everywhere and it always gives the best satisfaction. As a forage plant for hogs, cattle or sheep it can not be surpassed. There is but one true variety, and that is English Grown, and we offer you the true stocknot German Rape, as is sent out by so many other houses. Price: 1 lb., 15e 10 lbs., 90c; 25 lbs., \$1.85; 100 lbs., \$6.00.

\section{Broom Corn}

STANDARD EVERGREEN-Grows about eight to ten feet high, stands up well and is entirely free from crooked brush. The fiber is long and fine. It will not get red in the field before it is cut, but is strictly a green variety of brush. Price: 1 lb., 10c; 10 lbs., 50c.

\section{Cane}

EARLY AMBER-Farmers and stockmen say that Early Amber Cane is the most valuable fodder plan in existence. Not only is it adapted for feeding purposes, but its great qualities as a Sorghum producer is one of a paying investment, and has attracted general attention everywhere. Price: 1 lb., 10c; 10 lbs., 50c; 25 lbs., 90c; 100 lbs., \$3.50.

EARLY ORANGE-A variety well adapted for the South. It is from eight to ten days later than the Early Amber. Price: 1 lb., 10c; 10 lbs., 60c; 25 lbs., \$1.00; 100 lbs., \$3.00.

\section{Buckwheat}

\section{(52 lbs. per bushel.)}

JAPANESE-About a week earlier than silver Hull and yields more. It is much more productive than any other, succeeds well. The straw is heavier and it branches more. Best for bees. Price: Pk., 50c; bu., \$1.60.

SILVER HULL-Very good popuiar variety. Price: Pk., 50c; bu., \$1.60.

\section{Barley}

(48 lbs. per bushel.)

SUCCESS BEARDLESS BARLEY-Earliest variety in existence; is a heavy yielder. Price: 1 lb., 10c; pk., 50c; bu., \$1.40; 5 bu., at \$1.35 per bu.

SPRING BARLEY-A close second to the famous Beardless Barley. Price: 1 lb., 10c; pk., 40c; bu., $\$ 1.25$.

\section{Kaffir Corn}

One of the finest fodder plants, yielding two crops each season. Stalks grow to a height of five or six feet, each bearing numerous wide leaves. It is a wonderful yielder and one of the most profitable crops grown.

WHITE VARIETY-Price: 1 lb., 10c; 10 lbs., 35c: 25 lbs., 65c; 100 lbs., \$2.10.

RED VARIETY-Grows taller than the white variety. Price: 1 lb., 10c; 10 lbs., 45c; 25 lbs., 90c; 100 lbs., \$2.50.

\section{Flax}

(56 lbs. per bushel.)

Is one of the most productive and profitable crops and will yield you many fold the returns from numerous other crops. Price: 1 lb., 10c; pk., 65c; bu., \$2.00.

\section{Peanuts}

Field largely and are a paying crop. Planted in April, they ripen in August, and planted as late as July 1st, they will mature full crops before frost.

White-Price: 1 lb., 15c; 10 lbs., \$1.25. SpanishPrice: 1 lb., 15c; 10 lbs., \$1.25.

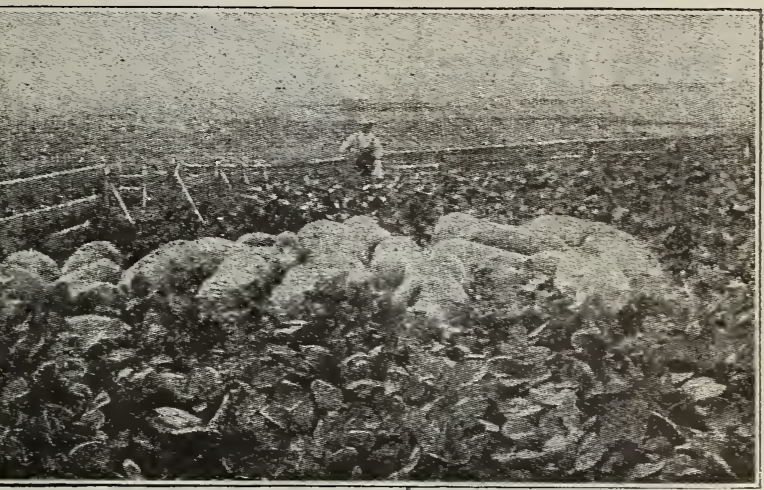

\section{Cow Peas}

WHIPPOORWILL-The favorite early bunchgrowing variety; has brown speckled seeds. Price: 1 lb., 10c; pk., 65e; bu., \$2.25.

CLAYS - A favorite with some for hay. Makes a heavy growth of vine and is late in maturing. Price: 1 lb., 10c; pk., 65e; bu., \$2.25.

BLACK-Seed black. Will make an enormous growth of vine in a short time. Equal to either of the above in feeding value, and is possibly the best variety for poor soils. Price: 1 lb., 10e pk., 85e; bu., $\$ 3.00$.

NEW ERA-The famous standard variety, grown extensively everywhere. Price: 1 lb., 10c; pk., 65e; bu., \$2.25.

MIXED-We always have a supply of mixed varieties; usually a little lower in price because of this and equally valuable for soiing. Price: 1 1B., 10c; pk., 65c; bu., \$2.10.

\section{Canada Field Peas}

Quite distinct from Cow P'eas, yet similar in valuable properties as fertilizer, food, etc. Price: 1 lb., 5c; pk., 60e; bu., \$1.90.

\section{Wild Rice}

Valuable as a forage plant forage plant for swamps and inundated lands, but chiefly as an attraction for wild fowl, ducks, geese, etc. Sown in water which is from 6 inches to 5 feet deep, with soft mud bottom. Sow in fall, as seed must be sown before it becomes dry. We make shipments in September only, in damp form.

Price: 1 lb., 40c; 10 lbs., \$3.50; 25 lbs., \$\$.00; 100 lbs., \$30.00.

\section{Speltz}

\section{0 pounds per bushel.)}

Of high value for feeding and will make a fair grade of flour. Makes excellent pasturage and good hay. The grain is claimed to be much richer than corn for feeding, and of superior quality for fattening hogs, cattle, sheep, poultry, etc. Usually sown in the spring. Price: Pk., 40c; bu., \$1.10.

\section{Vetch}

TVINTER OR HAIRY VETCH-Should be sown during August and September; mixed with Rye, it serves as a support for the plants, or in spring with oats or barley. It is the earliest crop for cutting. Price: 1 lb., 15c; 10 lbs., \$1.00; 25 lbs., \$2.50.

\section{Seed Rye}

CHOICE-(56 lbs, per bu.)-If sown early in the spring it makes an early and abundant pasture. Price: 1 lb., 10c; pk., 30c; bu., $\$ 1.00$.

\section{Sunflower}

MAMMOTH RUSSIAN-Sunflower Seeds are superior for poultry (said to improve the meat). Price: 1 lb., 10c; 25 lbs., \$1.25; 100 lbs., \$4.00. 


\section{Here is the Greatest Potato 0 OVFER}

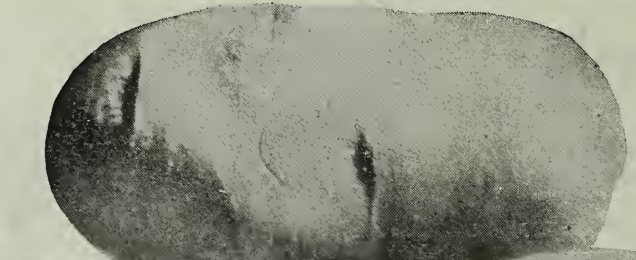

The EARLIEST POTATO

The LARGEST POTATO

The MOST BEAUTIFUL

POTATO

EVER DISCOVERED

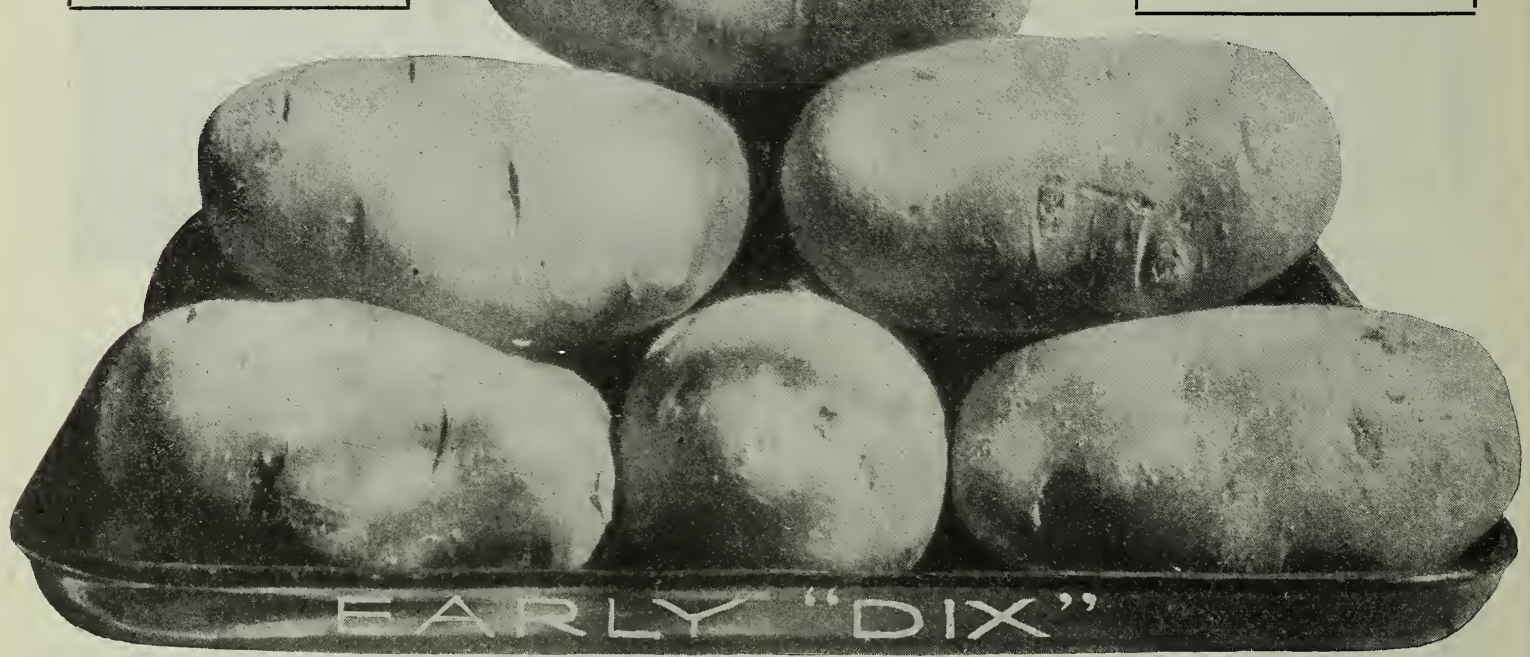

\section{St. L. S. Co.'s New Early “Dix" Potato}

The pride of the "Red River Valley." We offer it to you now as "The Greatest Potato on Earth." We mean just what we say. We are ready to stake our reputation that you will say so, too, when you have tried it. It is of the most uniform growth ever known-all large, no small potatoes being found. It is earlier than the famous Early Ohio. It is ten times better as a yielder, and has no yellow or black core. Its tops are of an upright growth, bush form. Its skin is of a light red pinkish color; its eyes are very shallow, and many; its dry and mealy nature is supreme. P'rice: $1 / 2 \mathrm{pk}$., 50c; pk., 75c; bu., \$2.50.

\section{Big Buster}

The finest late Potato in existence. Its make-up is of the most handsome type and as a main crop it will prove itself supreme. It is of large size, white skin. eyes shallow, very white inside, dry and mealy. Its yielding qualities are far ahead of any on the market today. Why people will plant old worn-out varieties, when they can get such new ones as these, is a mystery to us. We have only a limited supply this season. Price: 1/2 pk., 35c; pk. 60e; bu., \$2.00.

\section{Concaved Seed} Potato Knife

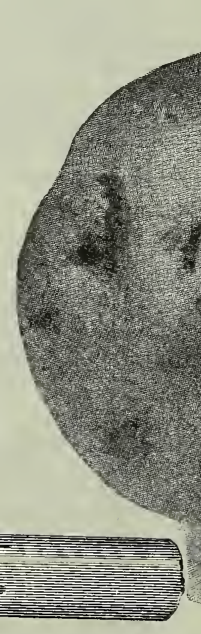

In our new Concaved and Curved Seed Potato Knife we not only offer you a knife that is good for planting season, but as a household article, for peeling apples, potatoes, etc. Each, 35c. 


\section{Nichol's Up-to-Date}

It is just the right shape, just the right size. A mealy, white, dry, flowery meat that is irresistible. A striking characteristic of this new Irish beauty is its productiveness. We will say right here that it will yield more potatoes by far on the same amount of ground than any other late sort you ever saw except Big Buster. We will back this statement by saying that it will be the most beautiful and of unilorm size. Price: $1 / 2$ pk., 35c; pk., 60c; bu., \$2.00.

\begin{abstract}
N E W I M P R V E D PEACHBLovi-The potatoes are of a very uniform size, none growing so small but that they can be readily used. It is of a beautiful type, producing large, white, smooth potatoes, with handsome, shallow pink eyes, giving them a very appetizing appearance when on the market. It is' an excellent keeper. Price: $1 / 2$ pk., 35e; pk., 60e; bu., $\$ 2.00$.
\end{abstract}

SNOW FLAKE-The tubers are of a good medium and uniform size, elongated oval, compresised, exceedingly symmetrical and remarkably uniform. Its mealiness, its pure, delicate flavor, and the evenness with which it cooks through. have never been eclipsed by any Potato. Pk., 50c; bui., \$1.75.

EARLY OHIO-Northern grown, in the Red River Valley. Much need not be said of this great potato. Among the standard early varieties it undoubtedly stands at the head of the list. An excellent keeper for such an early variety. Price: Pk., 40c; bu., \$1.40.

EARLY ROSE-No introduction is necessary for this standard productive variety. For earliness,
Use Arsenate of Lead on Potato Vines for Bugs, Etc.

\section{Sweet Potatoes}

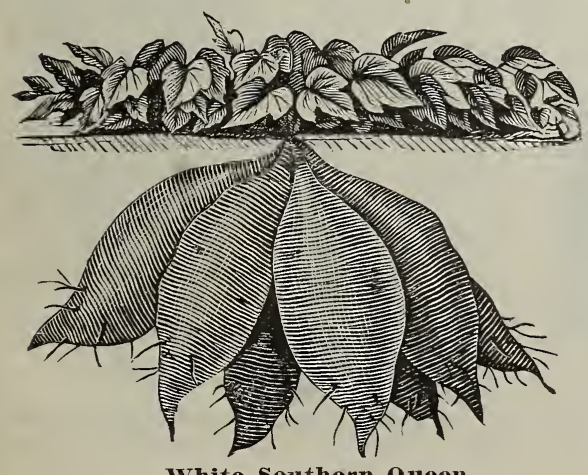

White Southern Queen

\section{Prices are Subject to Change on all Potatoes}

WHITE SOUTHERN QUEEN-These are the large "Yams," the famous Sweet Potatoes that are so popular in the South. Even the seed potatoes' are monster size, often weighing several pounds each; the gardener's favorite. P'rice: Pk., 50c; $1 / 2$ bu., 90c; bu., $\$ 1.50$.

EARLY YELLOW NANSEMOND-This potato is like the above, but averaging longer and not so chunky, very sweet and an ideal home or market sort. Price: Pk., 50c; $1 / 2$ bu., 90c; bu., \$1.50.

EARLY RED NANSEMOND-Similar to our Yellow Nansemond, only being of a red color, which many people prefer in preference to the yellow; very productive. Price: Pk., 50e; $1 / 2$ bu., 90c; bu., \$1.50.

RED BERMUD $\mathbf{A}$-One of the most popular varieties in existence, being of a very large and solid nature, yielding heavier than any other sort. Price: Pk., 60c; $1 / 2$ bu., \$1.00; bu., $\$ 1.75$.

SWEE'T POTATO PLANTS-Ready May 15th-Price subject to change.

Any of the varieties listed on this page. Price: 100 , 35c; $300, \$ 1.00 ; 1000, \$ 3.00$.

IMPOR'TAN'T-If you want to raise a big crop of POTAToEs, be sure to use our Pulverized Hog Manure. It will pay to drill same in row before planting. It is absolutely pure. See page 72 . 


\section{Seed Corn}

Hand Selected. All Butted and Tipped

Nichol's Yellow Dent

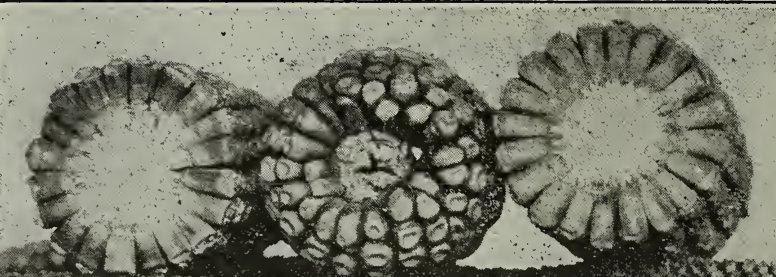

"Pure and Sure"

Look out for Cheap

Seed Gorn This

Year-It Will Not

Grow. Ours is

Tested.

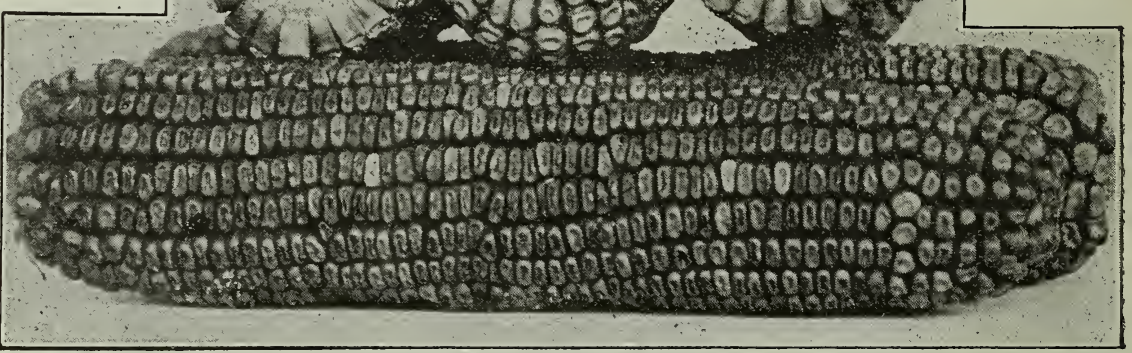

\section{Nichol's Yellow Dent}

The ears are large, handsome and well filled from butt to tip. The cob is very small. It is early, sure to mature from 95 to 100 days. 'The stalks grow from 8 to 10 feet in height. It will produce twice the amount on poor soil than any we have ever tried. It is the ideal corn of the corn world, and is surpassed by no other 95-day corn. Price: Pk., 75c; 1/2 bu., \$1.25; bu., \$2.00; 5 bu., at $\$ 1.90$ per bu.

GOLD BOND-Stalk grows to a height of 8 to 10 feet; ears grow 10 to 12 inches long, being very thick and uniform in appearance, with 18 to 20 rows of very deep, yellow kernels, set on a very small red cob and well filled over the tips. For high or low lands, it is the best. Do not fail to give it a trial this year. Matures in 95 days. Price: Pk., 75c; 1/2 bu., \$1.25; bu., \$2.00; 5 bu., at $\$ 1.90$ per bu.

YELLOW QUEEN-The grandest new Yellow Corn on the market today. We pride ourselves as being the first to produce such a wonderful variety. It is a big yielder of fine large yellow ears. The grains are deep and the cob is small. If you are looking for a corn that will make you more money than you have ever seen or planted heretofore, here is the corn that will do it. Price: Pk., 75c; 1/2 bu., \$1.25; bu., \$2.00; 5 bu., at \$1.90 per bu.

\section{White Star}

The greatest White Corn ever introduced. It has been tested thoroughly and has been admired by every one. Our local farmers are planting heavily of it. It is a very large white ear, with deep grains on a small white cob. Many stalks produce two and three ears. Will yield double any corn in this market. It matures in about 100 days and will out-shell any other. P'rice: Pk., 75c; $1 / 2$ bu., \$1.25; bu., \$2.00; 5 bu., at $\$ 1.90$ per bu.

IOWA SILVER MINE-Being a pure white, with deep grains and small cob. Stalks grow 8 to 10 feet in height and ears set well down toward the ground. Medium early. Price: Pk., 60c; $1 / 2$ bu., \$1.00; bu., \$1.75; 5 bu., at \$1.65 per bu.

BOONE COUNTY WHITE-This Standard White Corn is too well known to need any introduction. Its mammoth ears grow 7 to 10 inches in circumference and from 10 to 12 inches in length and contains from 18 to 24 rows. Its stalk is very large, with abundance of foliage. Price: Pk., 65c; $1 / 2$ bu., \$1.15; bu., \$2.00; 5 bu., at $\$ 1.85$ per bu.

CHAMPION EARLY WHITE PEARL-The earliest snow white Dent Corn. Grown extensively by gardeners for roasting ears. It is an immense yielding variety, and very uniform in shape, size, etc. Hence its great market demand. Price: Pk., 50c; $1 / 2$ bu., 85c; bu., \$1.50; 5 bu., at $\$ 1.40$ per bu.

PRIDE OF THE NORTH-A very early Dent variety grown everywhere. A good variety to plant late. Pirice: Pk., 50c; $1 / 2$ bu., 90c; bu., \$1.75; 5 bu., at \$1.65 per bu.

ST. CHARLES-An old, well-known white variety. Grains are pearly white, deep and set on a red cob, with 18 to 24 rows. We always have a large demand for this variety. Price: Pk., 40c; $1 / 2$ bu., 85c; bu., \$1.40; 5 bu., at $\$ 1.30$ per bu.

HICKORY KING-So large are the grains and so small is the cob that on an ear broken in half a single grain will almost cover the cob section. Frequently grows with three ears to the stalk. Price: Pk., 75c; $1 / 2$ bu., \$1.25; bu., \$2.00; 5 bu., at $\$ 1.90$ per bu.

POP CORN, MONARCH WHITE RICE-A superior quality of Pop Corn, very easily popped and very sweet, tender and white after being popped. P'rice: $1 \mathrm{lb}$., 10c; $5 \mathrm{lbs}$., 40c; 10 lbs., 75c.

WHITE PEARL-Smooth grained ears. Price: 1 lb., 10c; 5 lbs., 40c; 10 lbs., 65c.

White Star 

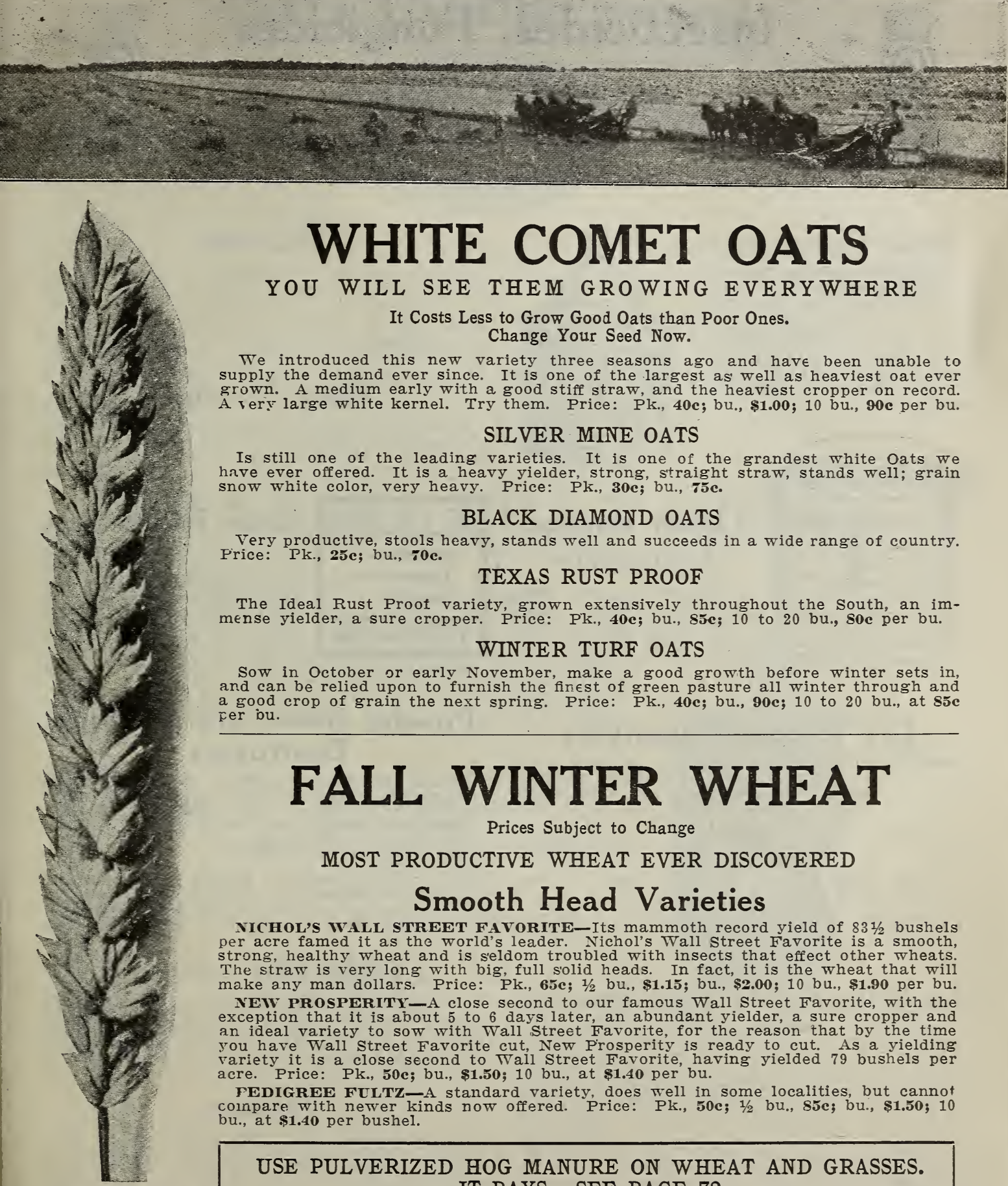

YOU WILL SEE THEM GROWING EVERYWHERE

It Costs Less to Grow Good Oats than Poor Ones.

Change Your Seed Now.

We introduced this new variety three seasons ago and have been unable to supply the demand ever since. It is one of the largest as well as heaviest oat ever grown. A medium early with a good stiff straw, and the heaviest cropper on record. A very large white kernel. Try them. Price: Pk., 40c; bu., \$1.00; 10 bu., 90e per bu.

\section{SILVER MINE OATS}

Is still one of the leading varieties. It is one of the grandest white Oats we have ever offered. It is a heavy yielder, strong, straight straw, stands well; grain snow white color, very heavy. Price: Pk., 30c; bu., 75c.

\section{BLACK DIAMOND OATS}

Very productive, stools heavy, stands well and succeeds in a wide range of country. Price: Pk., 25e; bu., 70c.

\section{TEXAS RUST PROOF}

The Ideal Rust Proof variety, grown extensively throughout the South, an immense yielder, a sure cropper. Price: Pk., 40e; bu., 85e; 10 to 20 bu., 80e per bu.

\section{WINTER TURF OATS}

Sow in October or early November, make a good growth before winter sets in, and can be relied upon to furnish the fintst of green pasture all winter through and a good crop of grain the next spring. Price: Pk., 40c; bu., 90c; 10 to 20 bu., at 85c cer bu.

\section{FALL WINTER WHEAT}

Prices Subject to Change

\section{MOST PRODUCTIVE WHEAT EVER DISCOVERED}

\section{Smooth Head Varieties}

NICHOL'S WALL STREET FAVORITE-Its mammoth record yield of $831 / 2$ bushels per acre famed it as the world's leader. Nichol's Wall street Favorite is a smooth, strong, healthy wheat and is seldom troubled with insects that effect other wheats. The straw is very long with big, full solid heads. In fact, it is the wheat that will make any man dollars. Price: Pk., 65c; 1/2 bu., \$1.15; bu., \$2.00; 10 bu., \$1.90 per bu.

NEV PROSPERITY-A close second to our famous Wall Street Favorite, with the exception that it is about 5 to 6 days later, an abundant yielder, a sure cropper and an ideal variety to sow with Wall Street Favorite, for the reason that by the time you have Wall Street Favorite cut, New Prosperity is ready to cut. As a yielding variety it is a close second to Wall Street Favorite, having yielded 79 bushels per acre. Price: Pk., 50c; bu., \$1.50; 10 bu., at \$1.40 per bu.

PEDIGREE FULTZ-A standard variety, does well in some localities, but cannot coinpare with newer kinds now offered. Price: Pk., 50c; $1 / 2$ bu., \$5e; bu., \$1.50; 10 bu., at $\$ 1.40$ per bushel. 


\section{Insecticides, Fungicides and Remedies}

For all Plant Diseases, Garden and Animal Insects PRICES SUBJECT TO CHANGES

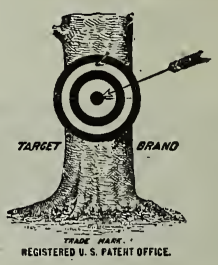

\section{Scale Destroyers}

TARGE'T BRAND SCALE DESTROYER-This we consider the most effective scale destroyer on the market today. It has many advantages over the old Lime-Sulphur Wash: Price: Qt. can, 35e; $1 / 2$ gal., 65e; gal., \$1.00; 5 gal., \$3.75; 50 gal. bbl., \$25.00.

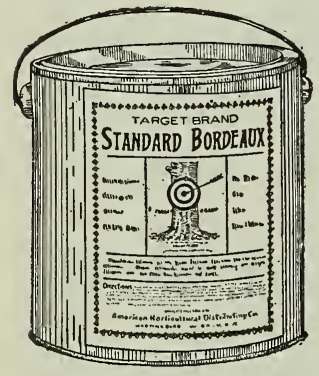

\section{Liquid Fungus Destroyers}

TARGET BRAND LIQUID BORDEAUX MIXTURE-Pint, 25e; qt.. 40e; gallon, \$1.20. Use one part to fifty parts water.

\section{Dry Fungus Destroyers}

DRY BORDEAUX MIXTURE-OF the same properties as' the liquid. Can be used dry or add water. 1 lb., 25e, makes 5 gallons spray; 5 lbs., \$1.00, makes 25 gallons spray.

HAMMOND'S GRAPE DUST-Avoids mildew on roses, grapes, gooseberries, etc., 5-1b. packages', 35e.

PARIS GREEN - $1 / 4$ lb., 10c; $1 / 2$ 1b., 20c; 1 lb., 40c; 5 lbs., \$1.90.

FLOWER OF SULPHUR-For mildew. 1 lb., 15e; 5 lbst., 60e; 10 lbs., \$1.00.

\section{Liquid Insect and Parasite Destroyer}

ARSENATE OF LEAD-This is without doubt the most effective poisonous insecticide yet discovered for the leaf-eating insects. Where other preparations have failed this has proven a specific remedy. It will never scorch, burn nor injure the most delicate foliage, but at the same time kills all kinds of leaf and vine-eating insects, and is free from their many objectionable qualities. Arsenate of Lead sticks to the foliage. For potatoes it cannot be surpassed. Comes in paste form, and only requires to be diluted with water. Price: 1-lb. tin can, 30c; 5-lb. wooden keg, \$1.25; 20 lbs., \$3.60; 50 lbs., \$8.50; 100 lbs., \$16.00.

\section{Nikoteen}

Contains 40 per cent nicotine. One pint contains as much nicotine as $200 \mathrm{lbs}$. tobacco stems. For spraying use two spoonfuls to 1 quart of water. Does not blight or color the most delicate plant. Price: Small size, 10e; $1-8$ pt., 25e; 1/4 pt., 50c; pt., \$1.50.

\section{Rose Nicotine}

A very powerful and highly concentrated insect and parasite destroyer. Price: Small size, 10c: medium size, 25e; large size, 50c.

\section{K I L L S \\ Sulpho- \\ Tobacco \\ soap. \\ INSECTS}

\section{Sulpho Tobacco Soap}

Kills all insect life in the window, garden or conservatory. Unsurpassed for roses; also valuable exterminator of moths, cockroaches and carpet bugs. Price: Small cake, 10c; large cake, 20c.
WHALE OIL SOAP-1-1b, cartons, 15e; 5 lbs., 75c.

\section{Powder Insect and Parasite Destroyers}

DEATH DUS'T-1-1b. cartons, 15c; 10 lbs., \$1.25. HAMMOND'S SLUG SHO'T-1-1b. cartons, 15e; 5 lbs., 30c; 10 lbs., 50c; 100 lbs., \$4.50.

TOBACCO DUST-1-1b. carton, 15e; 5 lbs., 40c; 10 lbs., 60e; 100 lbs., \$1.75.

HELLEBORE POWDERED- $1 / 4 \quad 1 b ., \quad 15 c ; 1 / 2 \quad 1 b$. , 25c; 1 lb., 50c.

ST. L. S. CO.'S SPECIAL MELON LOUSE KILLER -A special composition. It readily kills and prevents all insects that harbor around a melon patch. $1-1 b$ cartons, 15e; 5 lbs., 65e; 10 lbs., \$1.25.

\section{To-ba-kine (Aphis Punk)}

An improved fumigation preparation. Florists, you can depend upon this' as being the real article. With this it costs only $20 \mathrm{c}$ to heavily fumigate a $100-\mathrm{ft}$. house. Per box of 12 rolls, 60e; 1 case, 12 boxes, \$6.50; smaller size packages, 25e.

\section{Aphine}

The insecticide that kills plant lice of every species. Aphine, while admittedly a powerful insecticide, does not affect the most tender growths of plants. Price: Half pints, 40e; pints, 65e; quarts, \$1.00. 


\section{INSECTICIDES-Continued}

\section{WEED KILLER}

Destroys Weeds', Grass, Poison Ivy, Sumac, and all kinds' of undesirable vegetation. An application of this will keep drives, walks and tennis courts absolutely free from vegetable growth of any kind, thus doing away with repeated labor of hoeing and weeding. One part to 49 parts water. Price: Qt., 40e; 1/2 gal., 65c; 1 gal., \$1.00; 5 gal., \$4.00.

\section{Hammond's Copper Solution}

A concentrated liquid fungicide, for trees, vines or vegetables affected with rot, blight, scab or rust. Dilute 1 quart to 25 gallons of water and spray lightly. 1 qt., 60c.

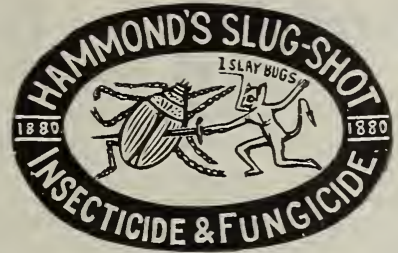

Conkey's

FLY KNOCKER

\section{SPRAYERS THAT SPRAY}

\section{The "Century" Barrel Sprayer}

The "Century" stands in the front rank of barrel sprayers. It has' brass working parts throughout. The large air chamber is located within the barrel; hence there is no projection to catch in low branches. The cylinder is submerged in the liquid and is constantly primed. The agitator is operated by the lever. An iron base is furnished, in which is a filling hole with cap. Has 21/4-irich cylinder with one $121 / 2 \mathrm{ft}$. section of $1 / 2$-inch hose, nozzle and pole holder Also " $\bar{Y}$ " coupling for attaching two discharge hose when desired. Price \$13.00.

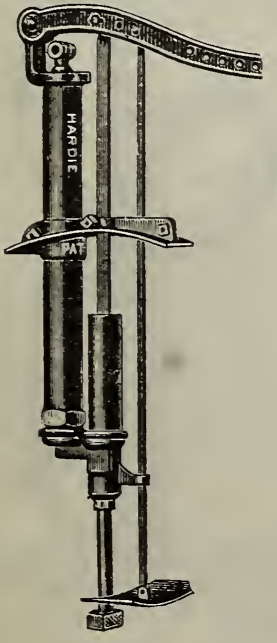

The "Hardie" Barrel Pump
It Pays to Spray, and the Best Sprayers are Best Payers.

\section{The "Hardie" Barrel Pump}

The accompanying cut shows one of the "Hardie" Pumps ready to mount on a barrel or other receptacle for liquid. The plunger, suction and discharge tubes' are of heavy seamless brass. The base or body of the pump is a brass casting. The valves are brass balls contained in a bras's cage.

The materials used in this pump will not be effected with any chemical .used for spraying. Copper, sulphate, or sulphur, lime and salt can be used without harming the pump in the least.

"The Hardie" has no stuffing boxes, leather or rubber washers to give trouble. Will fit either side or end of barrel; $12 \frac{1}{2} \mathrm{ft}$. 5-ply guaranteed hose Vermorel or Bordeaux nozzle, also coupling for two leads of discharge hose. Complete, \$13.00. 


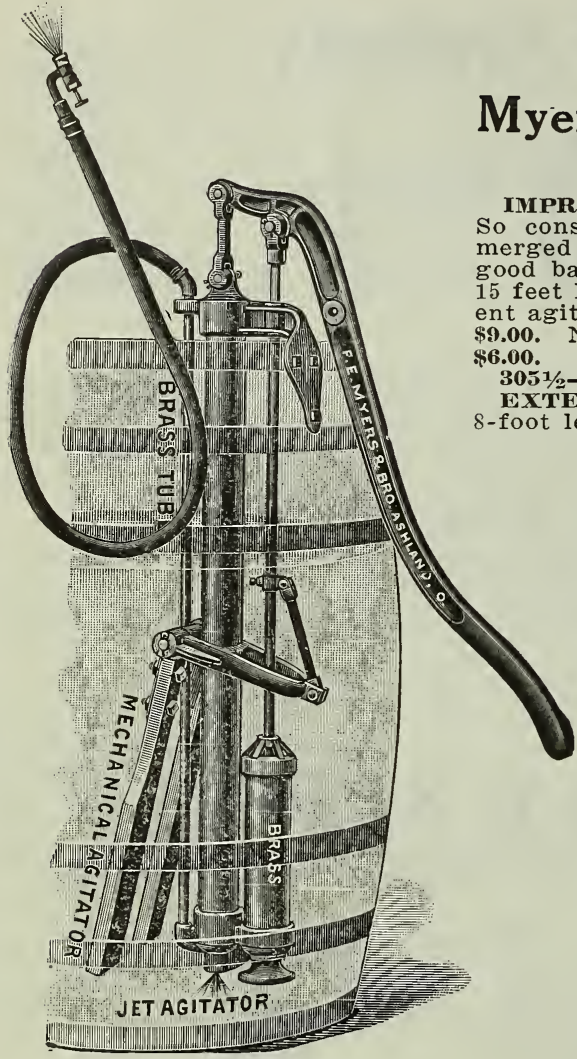

No. 306
Sprayers-continued

s'Perfect Double-Acting Barrel Spray Pumps

IMPROVED BRASS BARREL SPRAYER No. 306.so constructed that the cylinders are entirely submerged in the liquid. It fastens to the chime of any Is fitted with two discharge hose, 5-ply wich keeps the liquid well mixed. Price, .00. No. 305 same as 306 , with one discharge hose,

$3051 / 2-$ Same as 305 with mechanical agitator, \$7.00.

EXTENSION PIPES-Iron, 4-foot lengths, 25e each, ths, 45e each.

LEVER BUCKET PUMP AND BARREIL SPRAYER No. 324. - This is the besit combination made for small frult growers. Has brass' cylinders, patent agitators, coarse and fine stream nozzles. Being a combination pump it can be used on a barrel or in a bucket. A No. 1 machine for whitewashing as well as spraying. Price, \$4.00; with 8foot extension pipe, $\$ \mathbf{4 4 . 4 5}$.

MYERS, KNAPSACK SPRAYThe tank holds 5 gallons, fitted with lid and strainer, and is so arranged that no water can drip on the operator. The handle lever can be shifted from right to left shoulder at will. It can be set on the ground. Has brass stop-cock at end of hose and has large air chamber, ball valves, solid plunger and agitator, with 5 feet of hose, extension rod and nozzles. Price, galvanized, \$6.75; copper, $\$ 9.00$.

LITTLE GIANT BUCKET SPRAY PUMP.-For spraying and whitewashing. Has an adjustable footrest to fit any bucket or tub. Price, with 3 -foot hose, \$2.75.

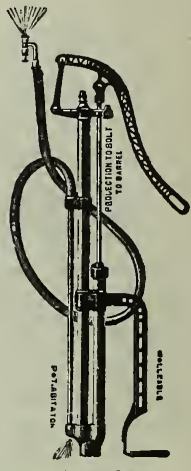

No. 324

Lever Bucket

Pump and

Barrel Sprayer

\section{Defiance Double-Acting Bucket Pump}

Is made entirely of brass, except the handle and foot-rest; has patent agitator, detachable hose, hemp packed plunger, brass ball valves, 2 nozzles, spray and solid stream; can be used for spraying or whitewashing. Price, each, \$3.75. (See cut.)

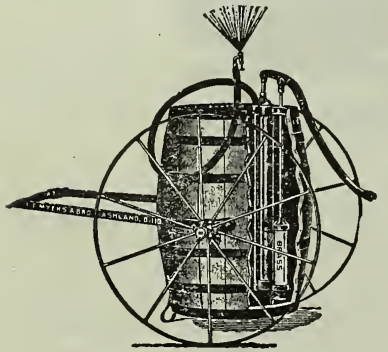

Barrel Cart

\section{The Boss}

All brass, double acting pump; fits any bucket. Furnished with 3 feet of heavy rubber hose; two interchangeable nozzles for a mist spray up to a solid stream; fine for disinfectants, whitewashing, etc. Nothing better. Only, \$3.00.

THE PRIZE BRASS SPRAY PUMP-It is fitted with the celebrated Acme nozzle, and will throw a fine spray or solid stream. It will fit any size bucket. Price, $\mathbf{\$ 3 . 7 5}$ each.

BARREL CART.-All steel, 36-in. wheels, ready to attach to a barrel. No legs to shut up. Always ready; best made (without barrel). Price, \$6.00.

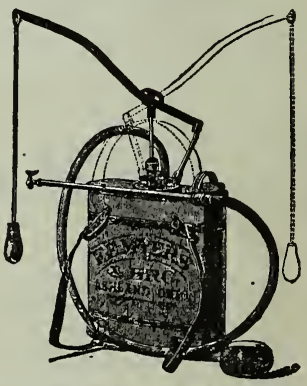

Myers' Knapsack Sprayer 


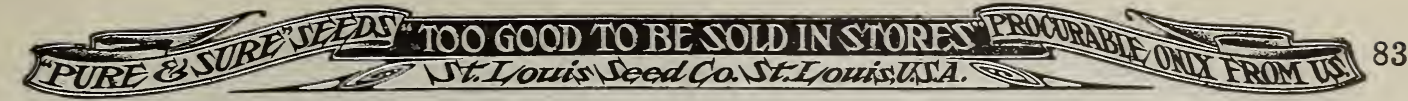
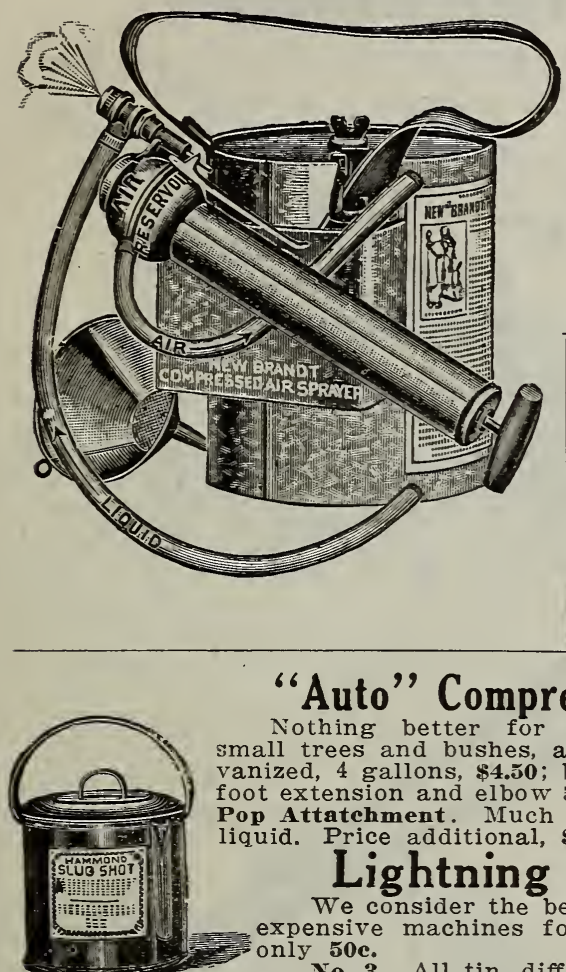

slug Shot Duster liquid. Price additional, \$1.35.

\section{"Auto" Compressed Air Sprayer}

Nothing better for spraying potatoes, melons, small trees and bushes, also for whitewashing. Galvanized, 4 gallons, \$4.50; brass, 4 gallons, \$6.65. Twofoot extension and elbow 50e additional. New "Auto" Pop Attatchment. Much easier to operate and saves

\section{Lightning Sprayer No. 7}

We consider the best, and fully equal to the more expensive machines for this purpose. 1 quart size,

50c. All tin, different style tank, 50c each.

No. 3. All brass, same style as No. 3 (see cut), $75 \mathrm{c}$ each.

U. T. K.-Compressed air Sprayer, shaped like No. 3 except has removable brass nozzle; DOUBLE VERMOREL $\$ 1.15$ each. NOZZLE-Throws streams in two directions. Price, \$2.00. SINGLE VERMOREL NOZZLE-Like above, only one nozzle. Price, 75e.

BORDEAUX NOZZLE-For spraying whitewash it cannot be surpassed. Unclogs itself when cock handle is turned. Fits all standard pumps. Price, \$1.00.

\section{SLUG SHOT DUSTER -Perforated bottom.} Half gallon size, 30c; gallon, 45e.

JUMBO DRY POWDER GUN-Price, 25e.

SLUG SHOT BELLOWS-F or applying slug shot, grape dust, etc. Small size, \$1.25; large size, \$2.00.

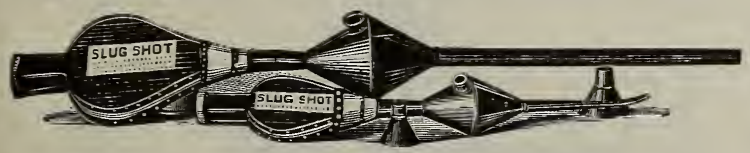

Slug Shot Bellows
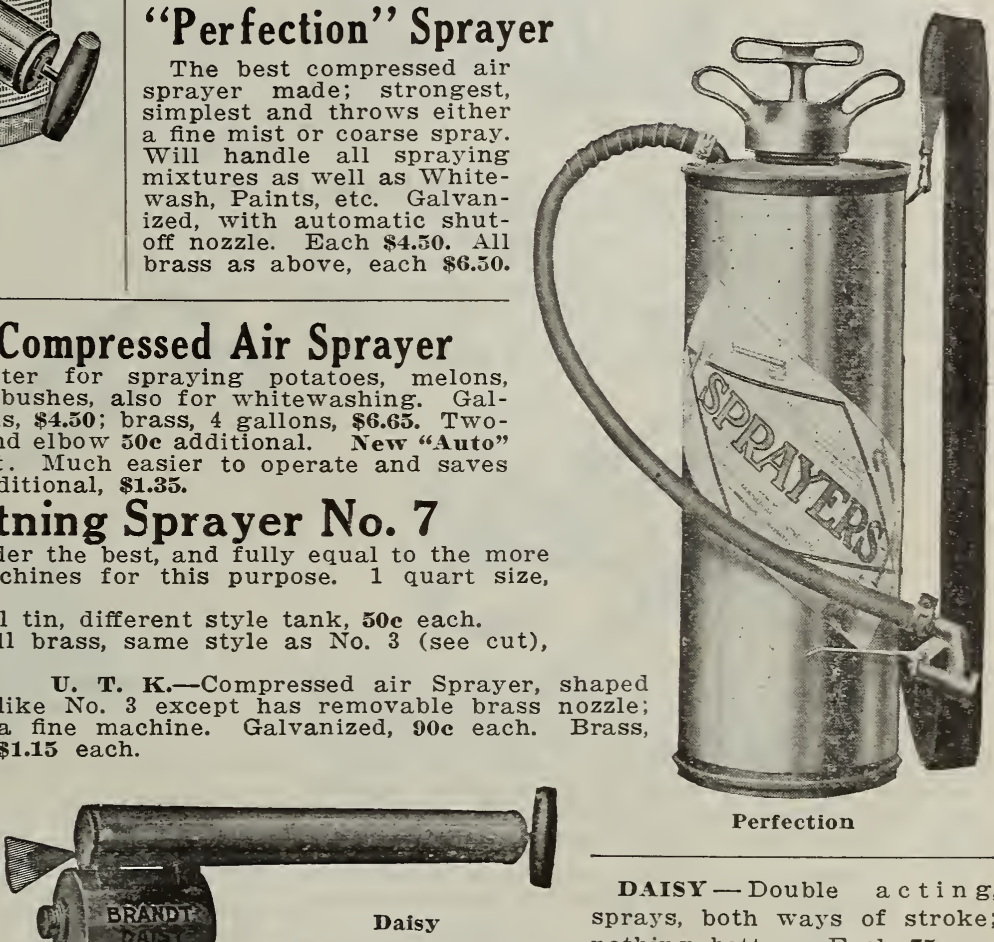

DAISY - Double a c ting, sprays, both ways of stroke; nothing better. Each ซsc.
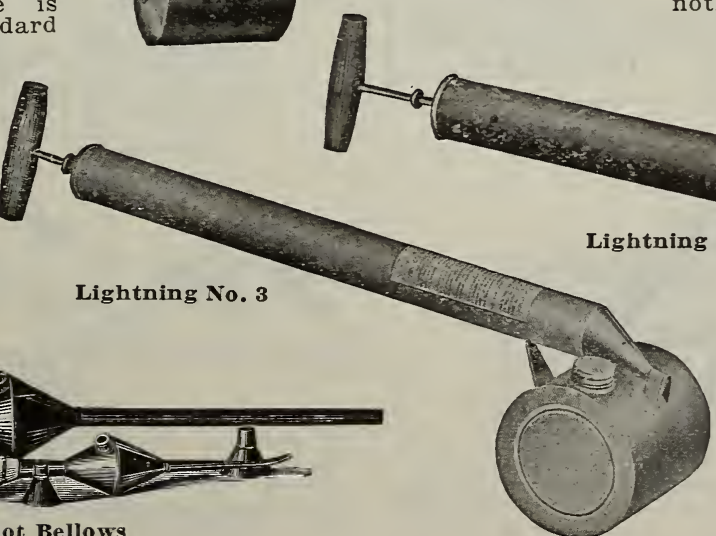

our Calendar "HOW, WHEN AND WHAT TO SPRAY" It's Free 


\section{Farm and Garden Implements}

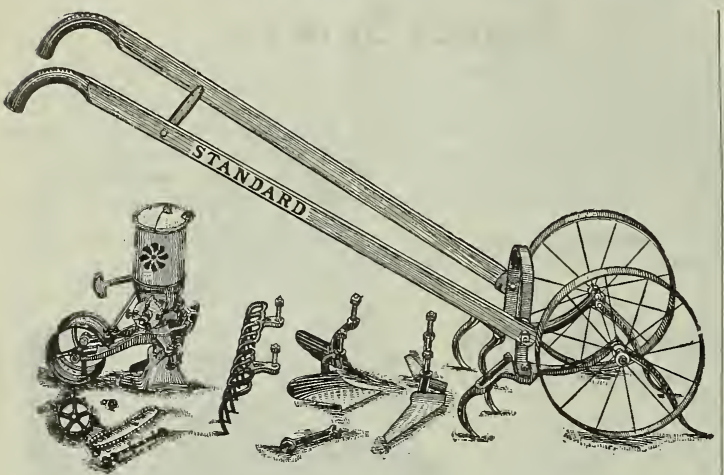

No. 9 COMBINED DOUBLE AND SINGLE WHEEI, HOE, HILL AND DRILL SEEDER.

Here is a complete machine. Simplest to change from one style to another. No other make like it. It has come to stay. We recommend the Standard as' always giving good results. You have three separate machines in this one only. Price, \$11.00.

As a Hill and Drill Seeder. Price, \$8.50.

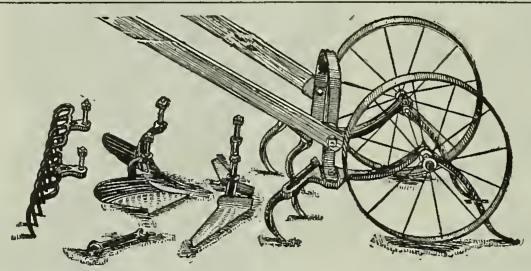

"STANDARD" No. 4 SINGLE AND DOUBLE WHEEL HOE, BOTH IN ONE.

Of all labor-saving tools this cannot be surpassed. Can be changed from one to the other in a few seconds, thereby saves buying two separate machines when you don't have work for both at same time. Frame all malleable iron attachments, with steel shovels. Price \$6.50; without rakes, $\$ 6.00$.

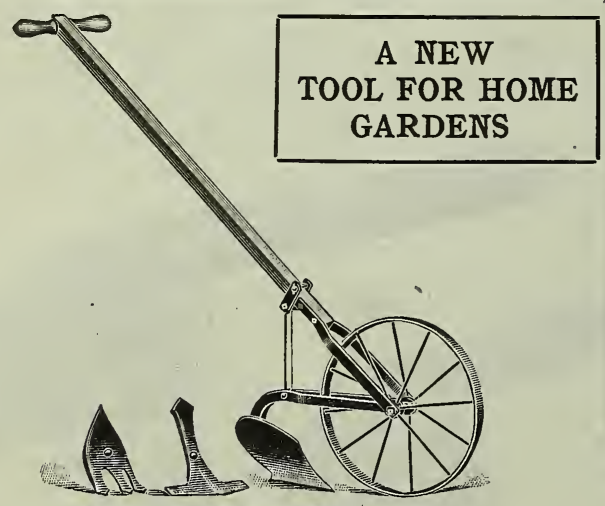

MONOGRAM WHEEL HOE.

Light in weight; strong in construction; convenient to use; complete in every way. Special offer, only \$2.00.
All These Machines Have 16-Inch Wheels With 11/4-Inch Tire, all Steel.

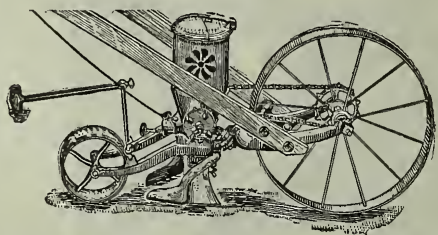

THE STANDARD No. 14-HILL AND DRILL SEEDER.

This drill is perfect in construction, is light but strong and well balanced. Will sow any kind of garden seed, either in hills $4,6,8,12,24$ inches apart in the row, or in continuous drill. Has revolving agitator, will not clog. It has 16-inch steel wheel with $13 / 4$-inch tire chain drive. Price $\$ 9.00$.

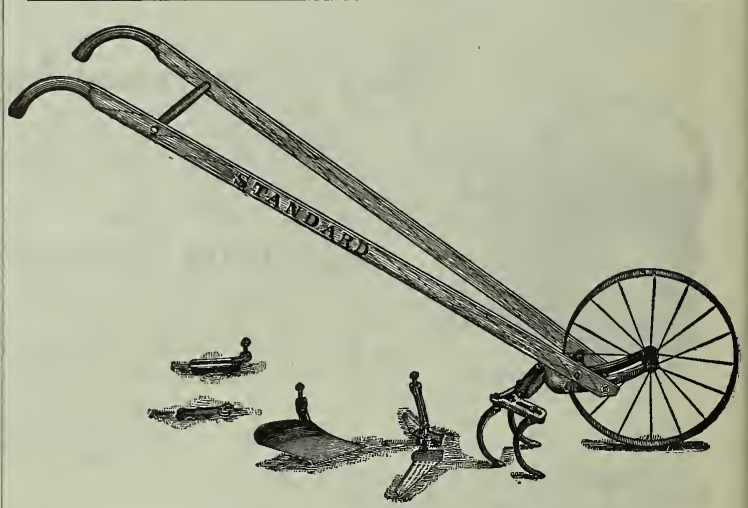

STANDARD No. 22, SINGLE WHEEL HOE.

A single wheel hoe, but can be used astride the row as well as for between rows. Very light running on account of good-sized wheels. Fine for small home gardens. Price \$5.00; with rakes, price $\$ 5.75$.

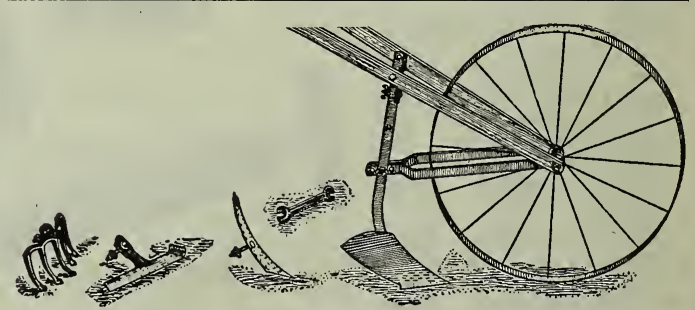

STANDARD No. 20, NEW STYLE WITH 24-INCH WHEEL.

This machine is made to use where a cheaper one is desired, such as in home gardens and for the market gardener to use in cultivating crops of larger vegetables. It is strong and durable, is adjustable in height by loosening a thumb nut. We recommend this for the price. Price \$3.00. 


\section{Farm and Garden Implements}

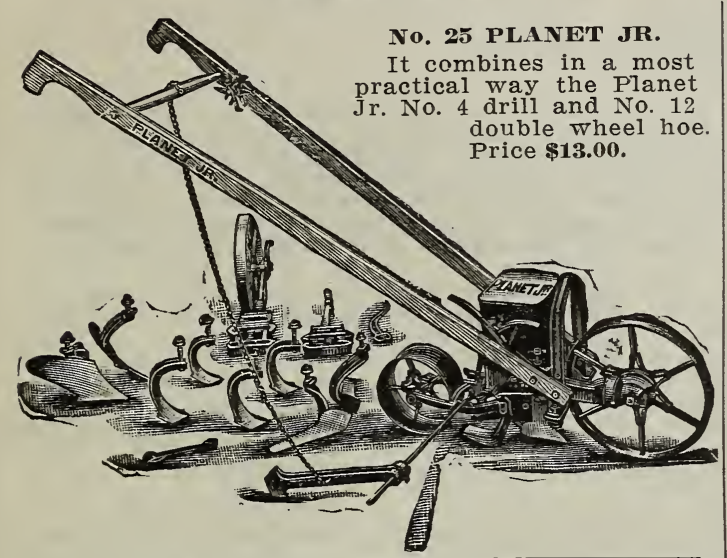

No. 4 COMBINED HILL AND DRILL SEEDER, SINGLE WHEEL HOE, CULTIVATOR AND PLOW.

With this implement the small farmer or gardener can do practically all the work in his small crops. Holds 2 quarts. Price, complete, \$10.50. Drill only, \$8.50.

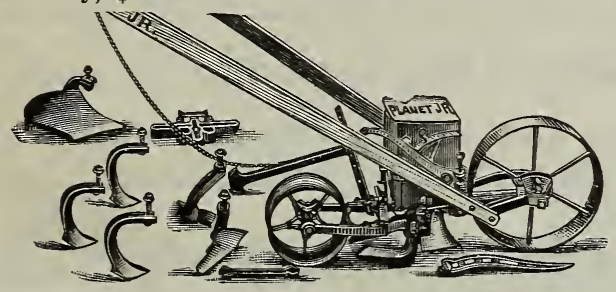

No. 12. DOUBLE WHEEL HOE, CULTIVATOR AND PLOW.

These tools shown are those gardeners use most. others can be added if wanted. Price \$6.50.
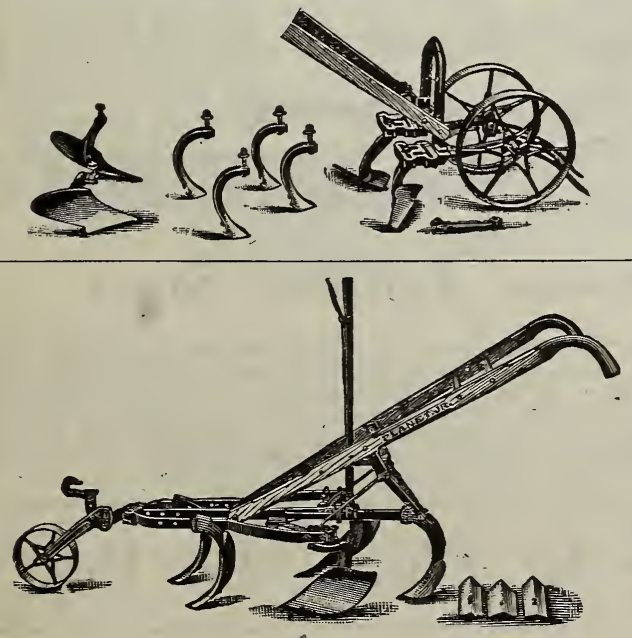

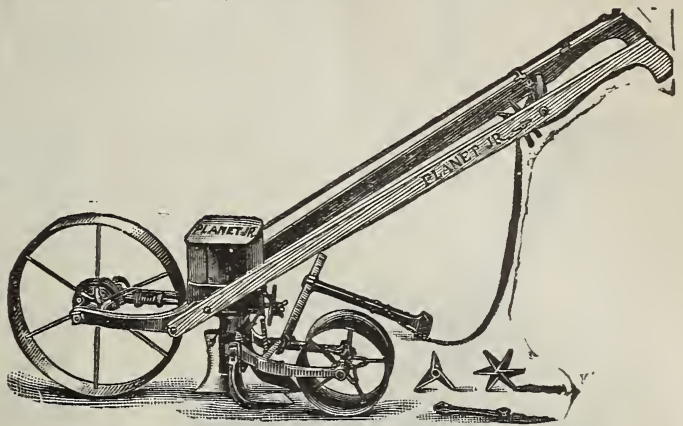

No, 3. HILL AND DRILL SEEDER.

Sows evenly in drills, and also drops in hills, at $4,6,8,12$ or 24 inches apart. The latest and most perfect development of the hand seed drill. Holds 3 quarts. Price $\$ \mathbf{1 0 . 0 0}$

No. 17. SINGLE WHEEL HOE, CULTIVATOR AND PLOW.

A fine tool for small gardens; does fine work and easy to operate. Price \$4.50.

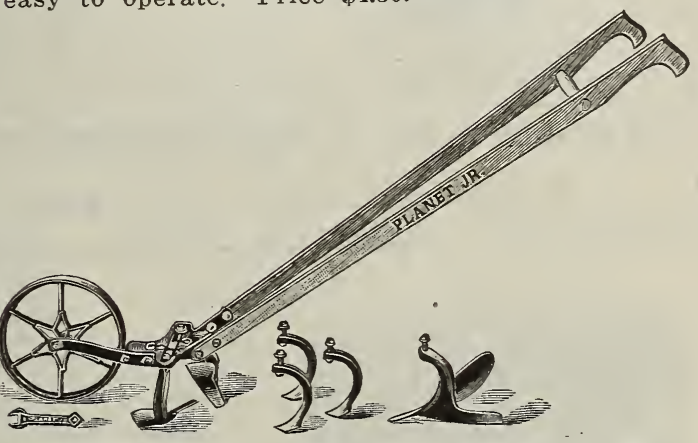

TWELVE-TOOTH HARROW AND CULTIVATOR.

This tool has rapidly grown into favor with farmers, market gardeners and strawberry growers. It has high frame and the chisel-shaped teeth cut an inch wide each. It may be set with teeth-trailing. Price: Complete (as illustrated) \$8.50; without Pulverizer, \$7.00. Without wheel lever and pulverizer, \$6.40

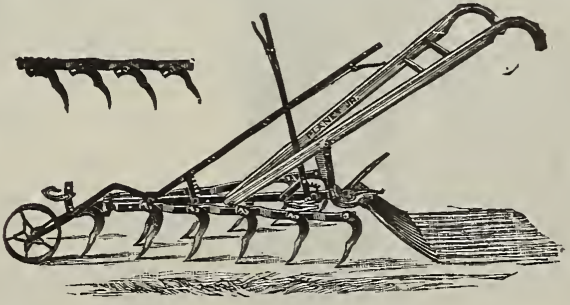

A practical machine for farm or garden.

No. 8 COMBINED HORSE HOE AND CULTIVATOR.

It is so strongly built as to withstand incredible strain, yet it is light and easy to handle. Price $\$ 8.50$

This machine pays for itself every day. 


\title{
"Velvetlawn" Seeders
}

\author{
Make Perfect Lawns and Greens
}

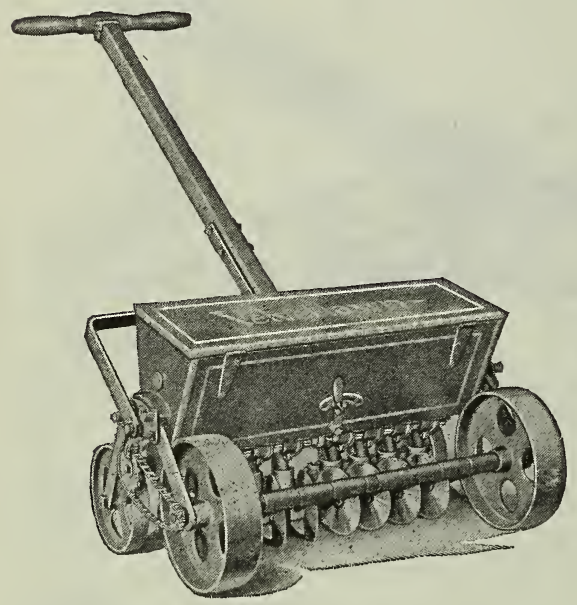

The illustration is a front view of the "Velvetlawn" Seeder. The ground wheels drive the feeds by means of sprocket wheels and chain. The feed dial on the front of the hopper has a number of notches in it into which fits the shifting lever. The shifting lever locks in the notches and enables the operator to sow in wide range of quantities. This lever can also be shifted to close the feeds entirely.

There are eight single discs on the machine, set two inches apart. Therefore it plants eight rows of seed at a time, or a strip sixteen inches wide. There are as many force feeds on the "Velvetlawn" Seeder as there are discs. Every feed sows an equal amount of seed, and the feeds can be set to sow any quantity desired. Each disc is independent in action and automatically conforms to the inequalities of the ground. Each disc has an independent roller which presses the soil back, covering the seed, allowing for uneven grounds.

It does equally as good on old lawns as it does on new. Every seed trench contains an equal amount of seed. No seed is wasted. The seed must grow, because it is in the soil and not on top of it. The wind cannot blow it away. Birds and fowls do note get it. Neither can heavy rains wash it away. The discs do not tear the sod; they cut it, cultivate the grass roots and make a finely prepared seed bed. For work in gardens and new grading the discs pulverize the soil. Send for Catalog. Each, \$20.00.

\section{We sold a lot of these Seeders last season on trial and every one gave} entire satisfaction. We assure you they are as represented.

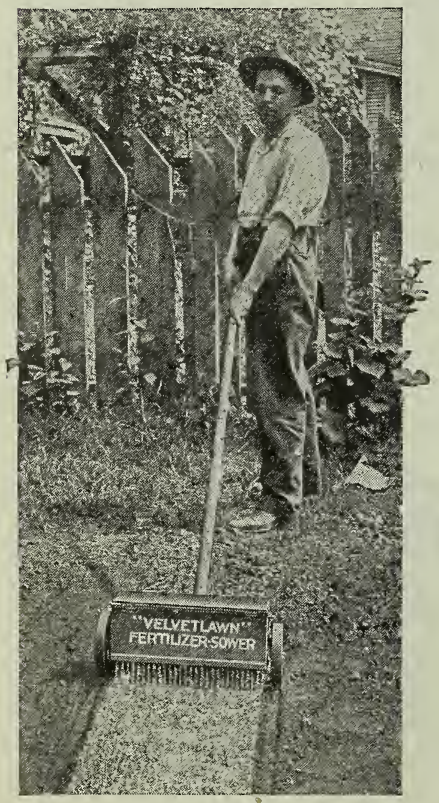

\section{"Velvetlawn" Horse Seeder}

This machine is same style as in above cut, only it sows a strip four feet wide, with all shifting devices, etc. It is used in making over old lawns, parks and large estates, as well as making a new lawn. Same is complete with shafts ready to hitch to and guaranteed to do fine work. Circular on request. Price, \$45.00.

\section{"Velvetlawn" Broadcast Seeder or Fertilizer Sower}

This machine is same size as one at top of page, except it does not have the discs and sows seed on top of ground as in cut at left. It is inexpensive and does the work far better and more even than by hand. Price, \$6.00.

\section{"Velvetlawn" Fertilizer Sower (See cut.)}

You can use lawn fertilizers such as pulverized sheep manure, pulverized hog manure, bone meal, etc., without any disagreeable odor around the house. There is none of it wasted by blowing away. We are proud to be able to offer our customers such a valuable machine, and we guarantee it in every particular. It saves time and money, and the work is done right. Price: Each $\$ \mathbf{6 . 0 0}$ and $\$ \mathbf{8 . 0 0}$.

\section{It Pays to Plant the Best}




\section{The 20th Century Lawn Roller \\ YOUR LAWN NEEDS A ROLLER.}

This season we are pleased to offer you the famous 20 th Century Lawn Roller. They are praised and endorsed by the leading lawn owners and yard men throughout the country. They have a highly polished surface with a silver-finished face, therefore making them the smoothest roller ever invented. The outer edges are beveled. They are made in sections. Handles are thoroughly reinforced and can easily be made heavier at will. We carry the following three sizes, which are the most used, but can supply you with any larger size if wanted:

Size No. 1-Roller 16 inches long; 2 sections; 15 inches in diameter; weight, 150 pounds. Price, $\$ 8.00$.

Size No. 2-Roller 24 inches long; 2 sections; 20 inches in diameter; weight, 225 pounds. Price, \$10.50.

Size No. 3-Roller 24 inches long; 2 sections; 20 inches in diameter; weight, 300 pounds. Price, $\$ \mathbf{1 4 . 0 0}$.

\section{Water Ballast}

This of great importance where one wants one for light rolling and heavy also. It is filled with water to any weight. Never rusts. Price, \$12.50.

\section{"Water Witch" Roller}

To weight the machine, turn on end, remove pipe plug by unscrewing, insert nozzle of garden hose or if necessary use pail and funnell, fill the drum to any desired weight from 115 lbs. to haif a ton, screw in the threaded plug and your Machine is ready for business. Drum 24 inches in diameter; 24 inches long; anti-rust inside. Price $\$ 15.00$ each.

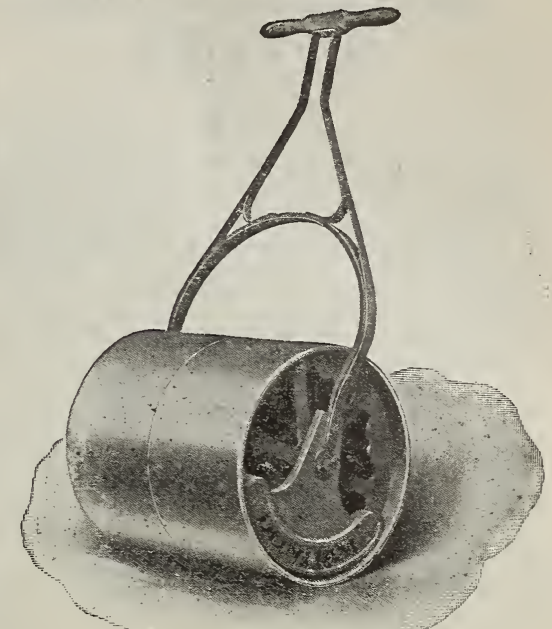

\section{The Mower that Cuts Clean}

\section{BACKED BY OUR GUARANTEE.}

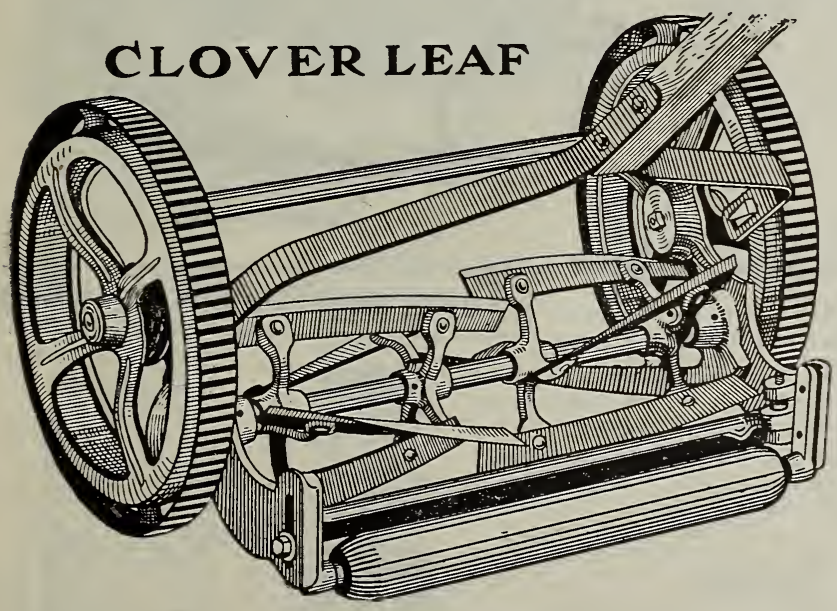

DAISY

No lawn mower with the old style reel can equal these Guaranteed to cut higher grass, run lighter and take better care of the grass than any other machine. The most powerful mower yet produced and the lightest running. We put this machine against any other make, and if it is no better, does not do as we claim, you can return it and get your money-you to be the judge. The double cutting blade, roller bearings and 12-inch wheels save you labor and cut evener. Price: 16-inch \$10.00 20 -inch \$12.00.

\section{New Principle in Lawn Mower Construction}

CLOVER LEAF is a ball-bearing machine. The great feature of these new mowers, you will see, is the double reel blades, which are of great importance. Combined with the 12-inch wheels and the new shaft boxing, make it a far lighter running mower than any ever made heretofore. It throws the cut grass to the center, entirely out of the way. A 20-inch mower of these makes runs lighter than a 16-inch of any other make. We guarantee to give satisfaction as represented or money refunded for same. These are not cheaply made mowers; best in quality. Self-sharpening. Cuts higher grass; has 12 -inch wheels. The only mower that takes perfect care of the cut grass. Price: 16 -inch $\$ 11.00 ; 20$-inch $\$ 12.00$.

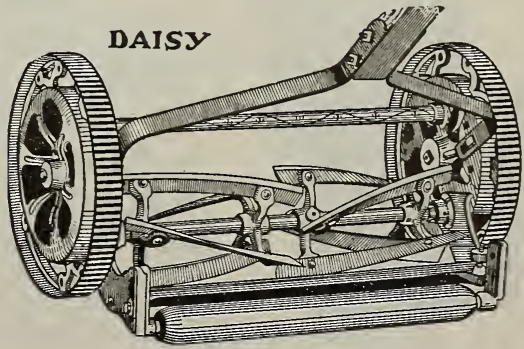




\section{MISCELLANEOUS SUPPLIES}

\section{Raffia}

We will furnish you the finest quality of Raffia on the market in twenty different shades. The Raffia is of the finest grade, the strands are long and uniform, making it a decided advantage in weaving. The natural Raffia is also used for tying up plants in field or greenhouse. Price; Natural, per lb. 25e; per 5 lbs. 20e per lb.; per bunch, 10e; Colored, per skein, 10e; 3 for 25e; per 1b. 60c.

\section{Reed}

Used for basket making, lattice work, etc. We carry all sizes adapted for schools, homes, etc.

No. 1

1 oz. 15e;

No. 3
$1 / 4 \underset{66}{1 b .30 e ;}$
$66 \quad 25 e ;$

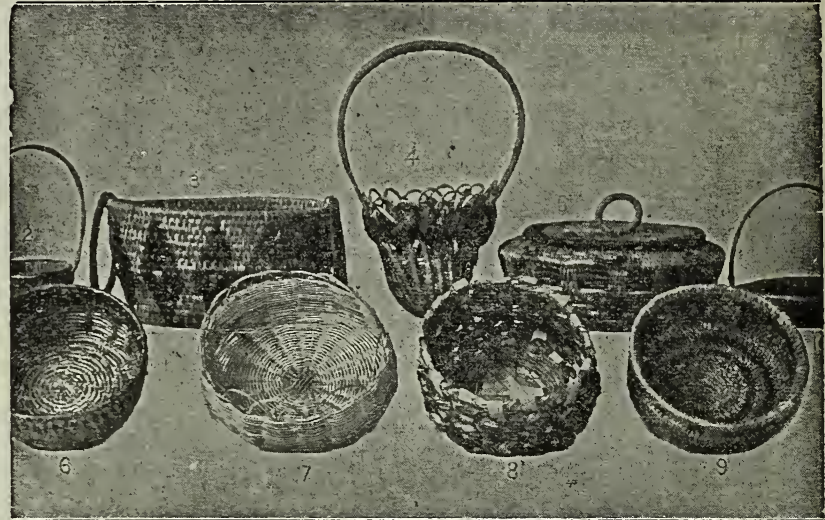

Baskets Made From Raffia and Reed

$\begin{array}{cr}1 & \text { lb. } \\ 66 & .80 \\ 66 & .70\end{array}$
No. 4

No. 5

No. 6

No. 7
1 oz. 10e;

$1 / 4$ 1b. 20e;

66 20e;

66 20e;

"6 20c;

1 lb. $\$ 0.60$

“6. .60

$66 \quad .50$

\section{Cyclone Grass Seed Sower}

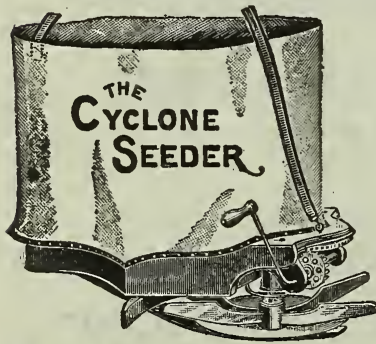

Sows all grass and grain seeds. It has a slant feed board and an oscillating feed plate which insures a uniform flow of seed. Price, $\$ 1.50$.

\section{Cahoon's}

\section{Broadcast Sower}

Sows all kinds of grass and grain seeds. 4 to 8 acres an hour. It will throw heavy seed 40 feet. Price,
\$3.00.
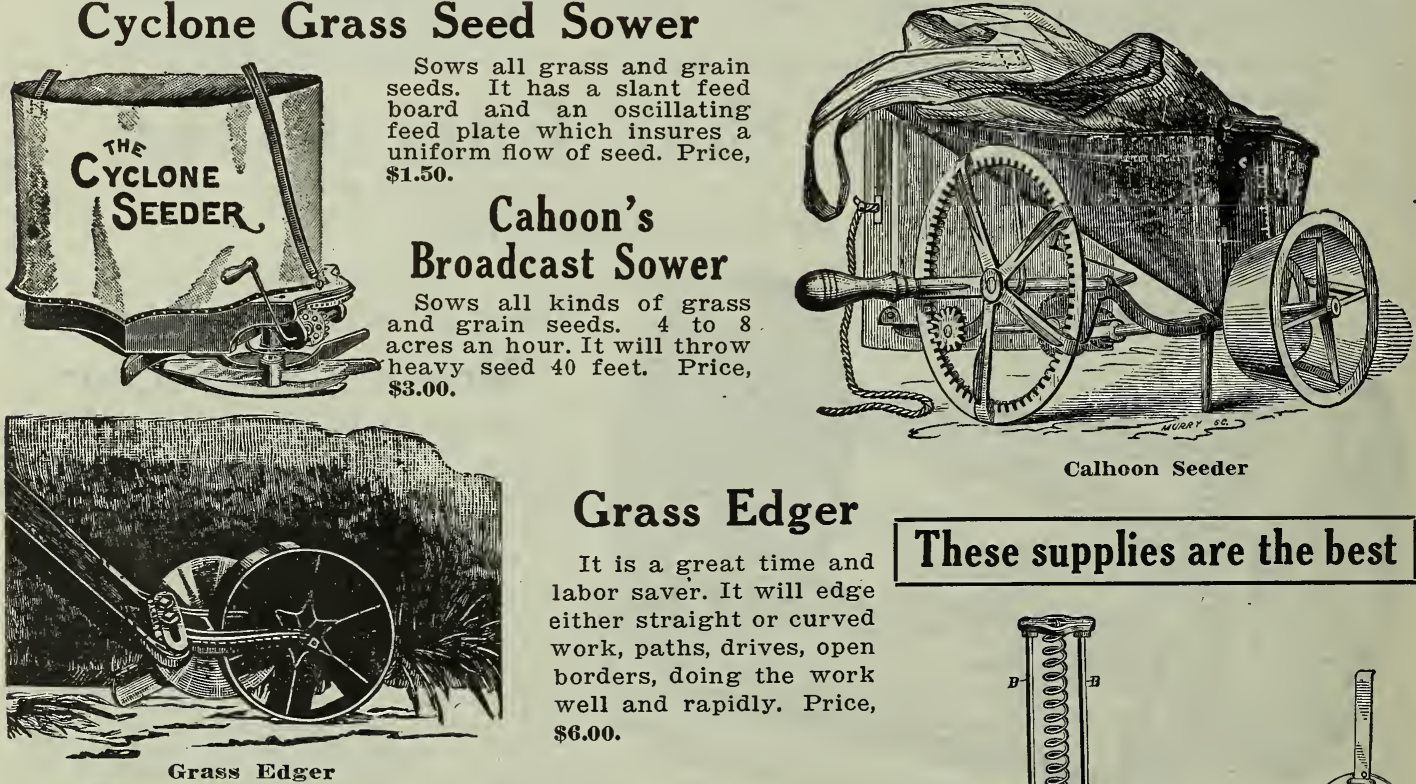

Calhoon Seeder

\section{Grass Edger}

It is a great time and labor saver. It will edge either straight or curved work, paths, drives, open borders, doing the work well and rapidly. Price, $\$ 6.00$.

\section{Mole Traps}

OLMSTEAD-The best trap made. Sure to catch them. Made of best material. Price, \$1.25.

RIDDLE-A very good trap for the money. Price, 75c.

\section{Seed Corn Grader}

THE BOSS GRADER-Does the same work as a large mill, only better separates the butts and tips, leaving only uniform grains, which insures planting evenly. Capacity 6 bushels per hour. Sin. gle, for tips only, \$1.00; Doubles, for tips and butts, \$1.50.

\section{These supplies are the best}

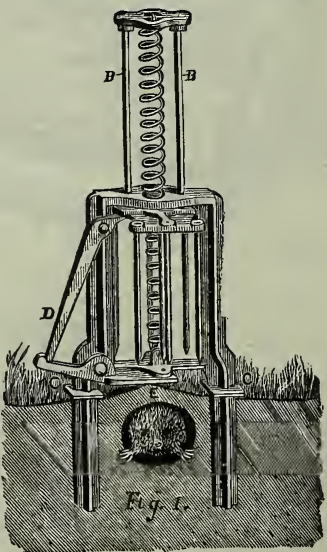

Corn Grader 


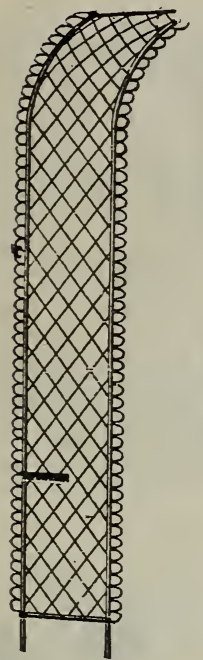

Porch Trellis

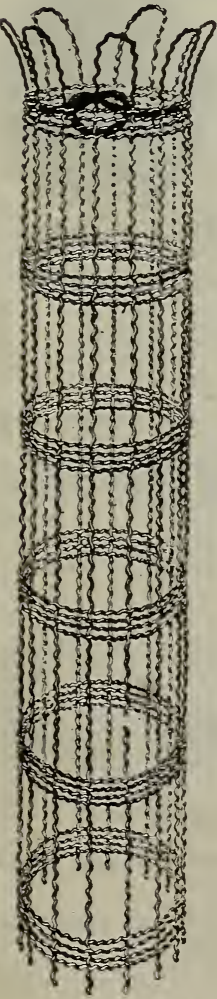

Wire Tree Box

\section{MISCELLANEOUS SUPPLIES-Continued}

\section{Trellises}

PORCH TRELLIS-Made of wire and painted; strong and durable; nothing better for your hardy climbers. 30 inches wide, 12 feet high, \$2.75; $14 \mathrm{ft}$.\$3.25; $16 \mathrm{ft}$. $\$ 3.75$.

BALLOON TRELLIS-A heavy wire frame suitable to place anywhere on the lawn for vines, etc., needs no other support. Painted, 4 feet high, \$1.50; 5 ft., $\$ 2.00 ; 6$ ft., \$2.50.

\section{Tree Guards}

EXCELSIOR TREE GUARDS-These are very essential to protect young trees from being barked or injured in any way and will last years. Made of heavy iron and well painted. $5 \mathrm{ft} .6$ in. $x 9$. Price $\$ 1.50$ each.

WIRE TREE BOX-(Like cut.) Made of best crimped wire, strong and durable; has neat appearance; 6 feet high. Price \$1.25 each. 75e.

Galvanized Wire Guard, made of screen wire, each

PLANT TUBS-Made of $7 / 8$-inch cypress and will keep for many years without rotting. Has drop handles and iron legs. Painted deep rich green. (See cut.)

No. 112 in. diam. \$1.25 No. 421 in. diam. \$2.25 No. $213 \mathrm{I} / 2$ in. diam. $\mathbf{1 . 5 0}$ No. 315 in. diam. $\mathbf{1 . 7 5}$

No. 524 in. diam. $\mathbf{2 . 7 5}$

FANCY TUBS-Natural wood in hard oil finish, with solid brass handles and hoops, suitable for any hall or room. Size $131 / 2$ inches diameter $\$ 4.50$; size 16 inches diameter, \$6.00.

\section{Flower Pots}

We are florists' headquarters for Flower Pots of every description. Send us your orders.

\begin{tabular}{|c|c|c|c|c|c|}
\hline $21 / 2-i n c h$ & per “doz & $\$ 0.20$ & $21 / 2-i n c h$ & per 100 & $\begin{array}{r}\$ 0.75 \\
1.50\end{array}$ \\
\hline “" & “" & $\begin{array}{l}.30 \\
.60\end{array}$ & $\begin{array}{ll}4 \\
5\end{array}$ & “" & $\begin{array}{l}\mathbf{1 . 5 0} \\
\mathbf{3 . 0 0}\end{array}$ \\
\hline “ & “ & 1.00 & “ & “ & 4. \\
\hline “ & each & .12 & " & per doz. & 1. \\
\hline " & “ & .15 & “ & " & 1. \\
\hline "“ & " & .30 & 10 & “ & 3. \\
\hline “ & “ & .50 & 12 & “ & 4 \\
\hline
\end{tabular}

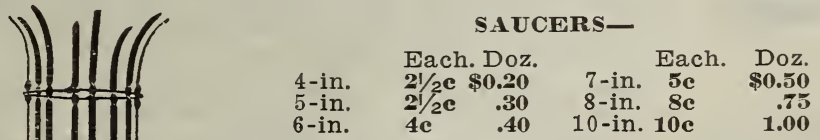

WIRE HANGING BASKETS-10 to 12 inches diameter. Price: 25c.

CLAY HANGING BASKETS-10 to 12 inches diameter. Price: 35c and 50c; large size, 50c.

MOSS SPHAGNUM-Large bale, \$1.50; 1/2 bale, \$1.00.

WOODEN LABELS-We do not sell less than 1000 of a kind. Larger quantity at same rate.

POT LABELS-Plain, per 1000, 4-in., 60c; 5-in., 75c.; 6-in., 90c; 8-in., \$2.75. Painted, per 1000, 4-in., 75c.; 5 -in., \$1.00; 6-in., \$1.25; 8-in., \$3.50.

\section{"Fibrotta" Plant Tub Saucers}

These are strong, and non-porous, do not leak like old style.

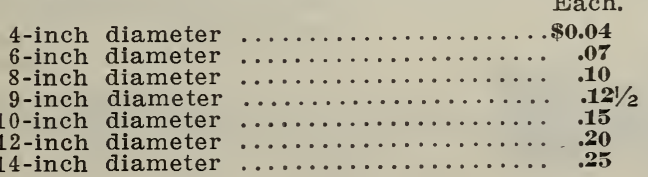

Doz.

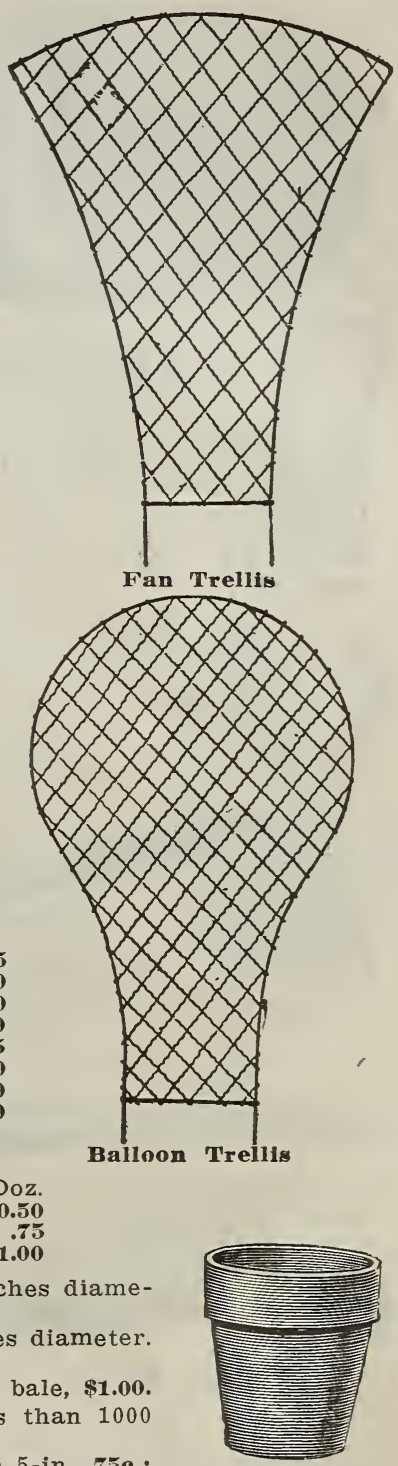

30.40

.00

1.25

1.60

$\ldots$

14-inch diameter

Iron Tree Box 

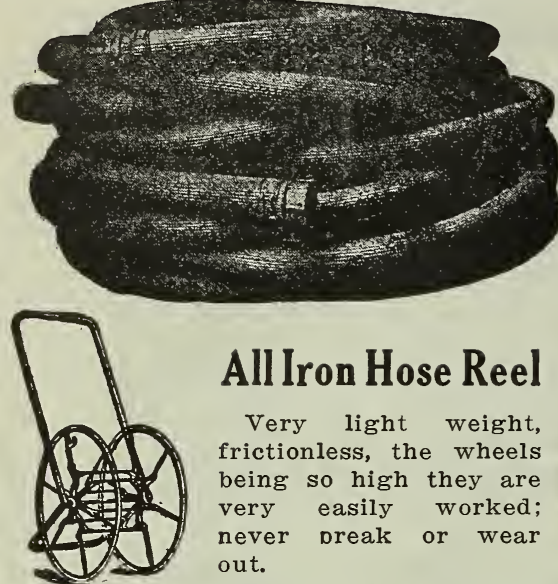

All Iron Hose Reel

Very light weight, frictionless, the wheels being so high they are very easily worked; never preak or wear out.

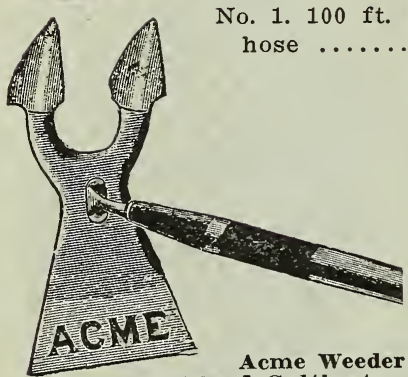
or Hand Cultivator

Transplanting Trowel

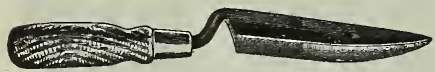

Garden Trowel
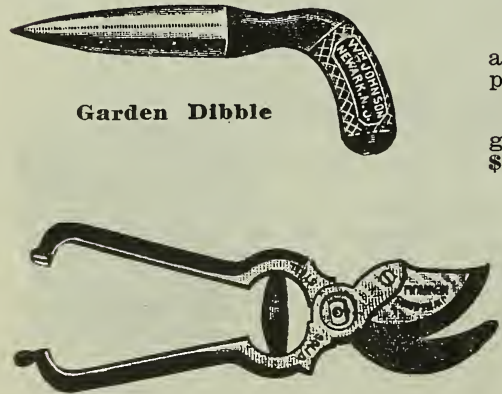
$\$ 1.00$.

\section{MISCELLANEOUS SUPPLIES-Continued}

\section{Rubber Hose}

Magic

Best hose on the market, finest quality of rubber being used in its manufacture; will last for years. We can supply in any length if advised at time of ordering. Price, $3 / 4$ inch, per 50 feet, $\$ 9.00 ; 100$ feet, $\$ 17.00$.

Diamond Brand. A fine grade of hose, which we can readily recommend. Comes in 50 foot lengths only. Price, $3 / 4$ inch (including plain couplings), per 50 feet, $\$ \mathbf{\$ 7 . 5 0}$.

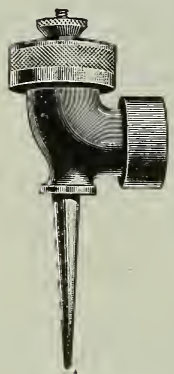

\section{Champion Lawn Sprinkler}

(Seje Cut.) It has adjustable nozzle for fine spray or coarse; stick the sharp end in ground and it works itself; can't get out of order.

Brass, each........75e

Water's Tree Pruners. The best Pruner on the market; cuts limbs to $3 / 4$-inch in diameter.

8 feet..........\$1.00

10 feet...........1.15

12 feet............ 1.25

ACME WEEDER OR HAND CULTIVATOR.Combination hoe and cultivator combined. Made with a solid steel shank, polished blade and points, bronzed malleable shank and bronzed steel ferrule. (See cut.) Price, 85c.

\section{Garden Trowels}

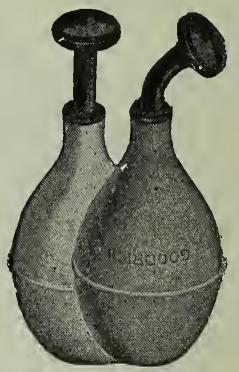

FORGED STEEL GARDEN TROWELS.-Made of Plant Sprinklers one piece of steel, they are strong and stout. For market gardeners' use they are the very best trowel; 4-inch, 30c; 5-inch, 35e; 6-inch, 40e; 7-inch, 45c. Cheaper grade, 15c.

TRANSPLANTING TROWELS-Made of the same material as the above; 5-inch, 10c; 6-inch, 15e; 7 -inch, 15c.

AMATEUR GARDEN TROWEL-4-inch, riveted handle. Each, 10c.

GARDEN DIBBLE-All iron; is used for transplanting small plants. Has polished steel point. An indispensable tool in the garden. Each, 35e; 3 for $\$ 1.00$.

SHEARS FOR PRUNING-Very strong steel blades and good spring. Price: 50e; best grade, 75e.

GRAFTING WAX-1 1 b. 25e.

CELERY RIBBON-We can supply you with this in a blue shade, about $3 / 8$ inch wide, on wooden spools of 1000 yards each. Price: \$2.00 per spool.

TWINE-Best jute, 2 or 3 ply, per lb. 20c; 6 lbs. \$1.00. Flax, best grade for tying bags, small, medium or large size, per lb., 35e; 3 lbs.

ASPARAGUS KNIFE-Saw edge, each, \$1.00.

20TH CENTURY GRASS SHEARS-Steel blade, steel spring, cast frame. A bargain, only 25c.

ALL STEEL COMBINATION SHEEP AND GRASS SHEARS - The best made, only 50c.

PLANT SPRINKLERS-Straight neck, size 4 oz. 75c; 6 oz. 90c. 


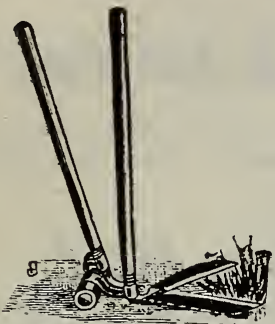

Edge Shears

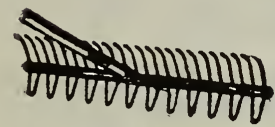

Reversible Steel Lawn Rake

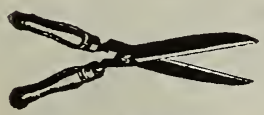

Hedge Shears

Miscellaneous Supplies

\section{Terra Cotta Grass Seed Novelties}

These are the latest craze-a small hollow earthen figure. Fill with water, sprinkle grass seed on the head, and his hair will grow. A beautiful window ornament. Made in various sizes and images. The laughing Jew (see cut), 4 in. high, 15c; medium, 5 in. high, 20c; large, 6 in. high, 25c. The Laughing Baby, The Crying Baby, same size and prices as above. Pigs, 15c; Lions, 15c.

The above prices include grass seed for each figure ordered. Special prices in large quantities.

EDGE OR BORDER SHEARS (see cut), made of best steel with wheels, \$2.75.

HEDGE SHEARS-8in., with notch, \$1.50; 9in. blades, with notch, $\$ 1.75 ; 10-$ in. blades, with notch, \$2.00.

The "notch" is at the heel of the blades, for cutting small branches.
LAWN RAKE-Heavily tinned steel teeth. The arched teeth for leaves and litter, and the opposite side for fine cut grass. Twenty-four teeth closely set in a 21 inch head. Price, 50c. each.

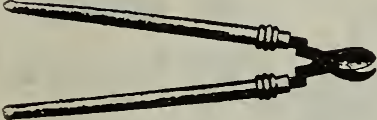

Lopping Shears
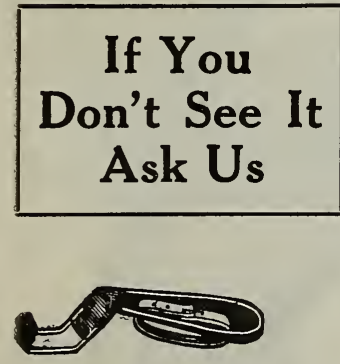

Lang's Weeder

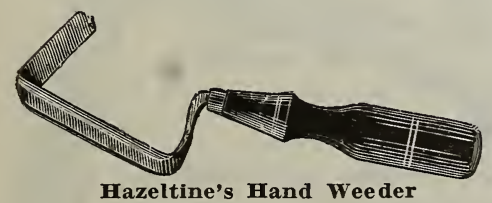

Hazeltine's Hand Weeder

\section{Pennsylvania Fruit Pickers}

Attach to pole of any desired length. Saves all climbing, especially on young trees. Price, 50c.

AUTOMATIC RAKE-One of the finest rakes made. Has 26 teeth, $251 / 2$-inch wood head, oil finished and varnished; selected hickory, with japanned malleable iron casting. Price: \$1.00.

PLANT BED CLOTH.

Our cloth is composed of waterproof fibre, 1 yard wide, about 40 yards to a bolt. Light grade, per yard, 9e; by the bolt, 7c per yard. Medium grade, per yd., 12c; by the bolt, 11c per yd. Heavy, per yd., 14c; by the bolt, 12l/2c per yd.

\section{Hand Weeders}

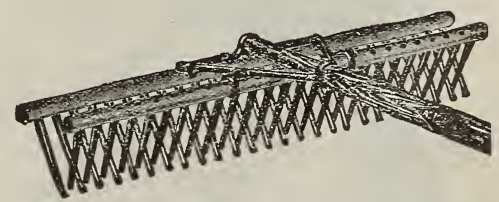

Automatic Rake

HAZELTINE'S HAND WEEDER-One of the most useful garden tools made. Every owner of a garden should have one. Price: 25c.

EXCELSIOR HAND WEEDER-For weeding seed beds, stirring soil in hot beds, etc. Price, 10c each; 3 for 25e.

LANG'S HAND WEEDER-In our opinion this is the best of all weeders. Price: 25c.

CLIMAX WEED PULLER-A neat little tool, very much used by landscape gardeners and lawnmakers everywhere. For cutting out weeds, dandelion, etc., it is indispensable. Price each, only 75 .

Climax Weeder
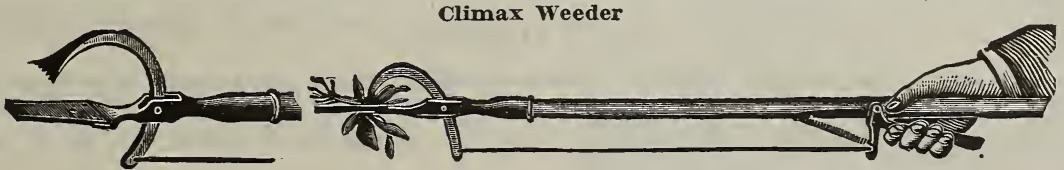


\title{
Birds that Sing and Birds that Talk \\ THE MOST POPULAR OF ALL PARROTS

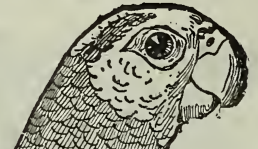

The Harmonious Blending of Human Voices. The Takology

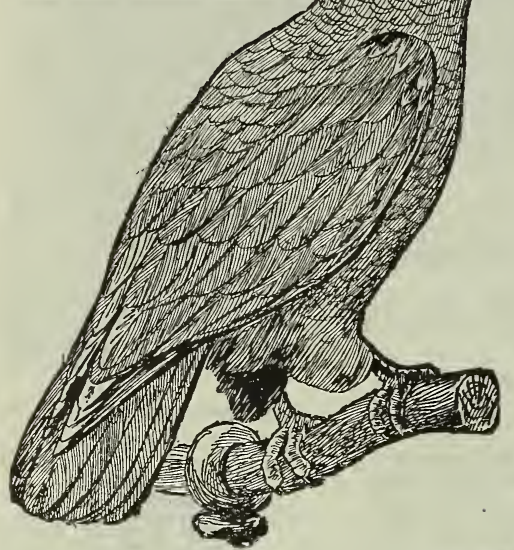
of the Parrot Tribe. The Inovation of Mimiery. The Fun Furnisher to His Majesty-His Master.

\section{Mexican Double Yellow Head}

A native of Mexico. They are of a beautiful plumage, as for talking, singing and whistling, they are superior to all other varieties. Its color is of a handsome dark green, with bright red and blue tinted feathers on the edge of the wings and tail, the top of the head being composed of a beautiful mass of pale orange color over his head and neck, thus giving it a very pretty appearance. Young birds, in July and August, $\$ 6.00$ to $\$ 9.00$ each. Older ones, just talking, from $\$ \mathbf{\$ 1 0 . 0 0}$ to $\$ 20.00$ each.

\section{Pedigree "Seifert's Hollow" Roller Canary}

\author{
(See Cut)
}

Here is a New Canary. First of its kind in America. We are proud to announce we are the only house here that can offer them; known all over France and Germany as the best singer.

In this bird we have what is considered by bird breeders the world over the "King" of all Canaries. He is what breeders term a professor, and is kept almost exclusively by

the bird raisers to teach

other birds the art of sing-

ing. Price $\$ 15.00$ each.

\section{Leipzig Canary}

"The Bird Without a Flaw"

We are pleased to be able to offer you while they last a bird of this variety for only \$10.00.

We are the only house in America that can supply you with the Leipzig Canary.

\section{-}

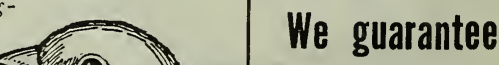

ST. ANDREASBERGER CANARY

These are a fine grade of roller Canaries. We import them direct ourselves. Each \$5.00.

\section{GERMAN ROLLERS}

A high grade German Canary; fine singers. Each \$3.50.

\section{HARTZ MOUNTAIN CANARY}

Hartz Mt. Canary, the famous German warbler, very common in this country, each $\$ 2.50$.

FEMALE CANARIES ready for mateing in January, February and March. Each \$1.00, \$1.50, \$2.50.

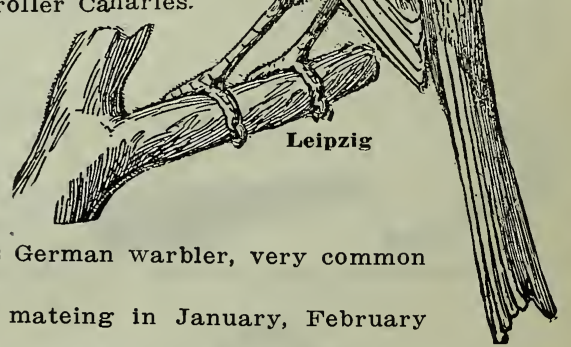

THE AUSTRALIAN SHELI PARORUETS

Love Birds Must Be Ordered in Pairs.

They are very affectionate and are known as "Love Birds." In fact they are so affectionate that they will not live separated, hence they must be kept in pairs. Per pair \$5.75. 


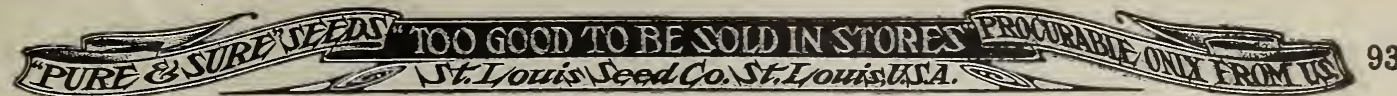

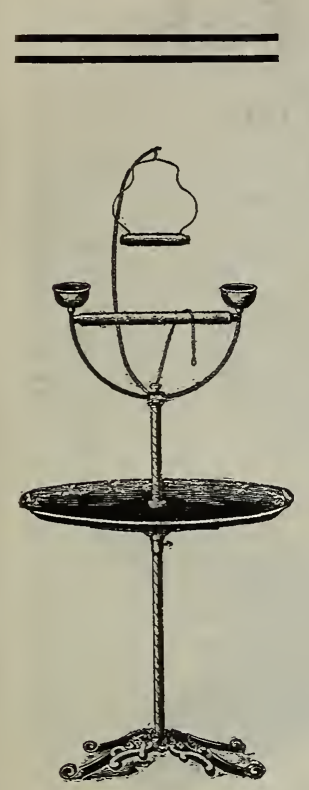

\section{Cages}

\section{Parrot Cages}

Our Round Parrot Cages have Brass Knobs and Tin Washers, Heavy Hangers with Brass Nuts, Hardwood Perches and Swings, Heavy Zinc Bottoms, Tinned Iron Feed Cups, No. "A" has a plain Tin Knob, no Washer and no swing.

No. A. 12 inches diameter...\$1.50 No. B. 14 inches diameter.... 3.00 No. C. 16 inches diameter..... 3.50 Square Parrot Cages No. 5. (Without draw pan.) $15 \times 13$ inches, 4 cross bars ................\$3.50 No. 7. $17 \frac{112 \times 15}{10}$ inches, 4 cross bars .................50 No. 5. 15 (With draw pan.) 13 inches ......\$4.50 No. 7. $171 / 2 \times 13$ inches.........

\section{Parrot Stand}

Height, including swing, 5 feet, 9 inches. Gold bronzed Iron Foot, Fancy Brass Standard, Japanned Tray, Tinned Iron Feed. Cups, Hardwood Perches, Brass Chain.

Each ............\$10.50 Without Swing ...............50

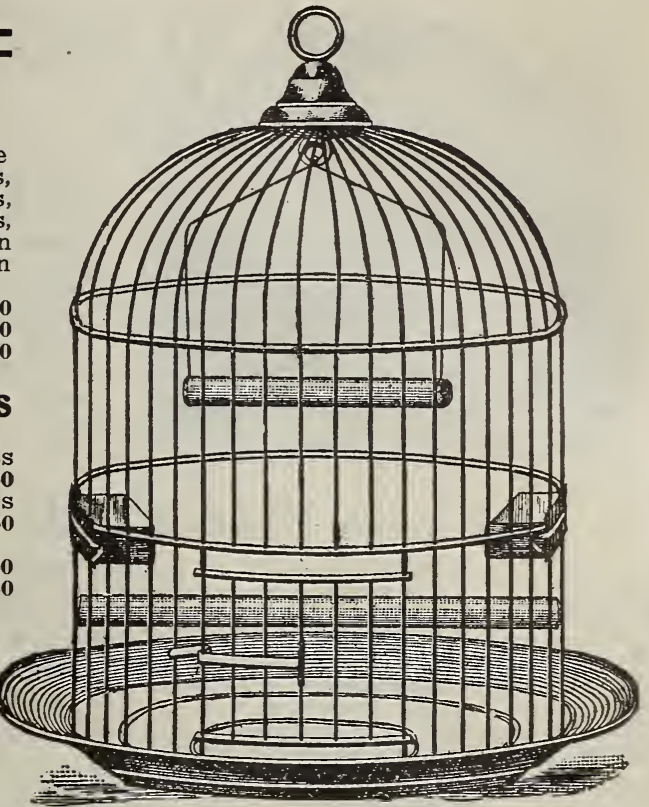

Round Parrot Cages

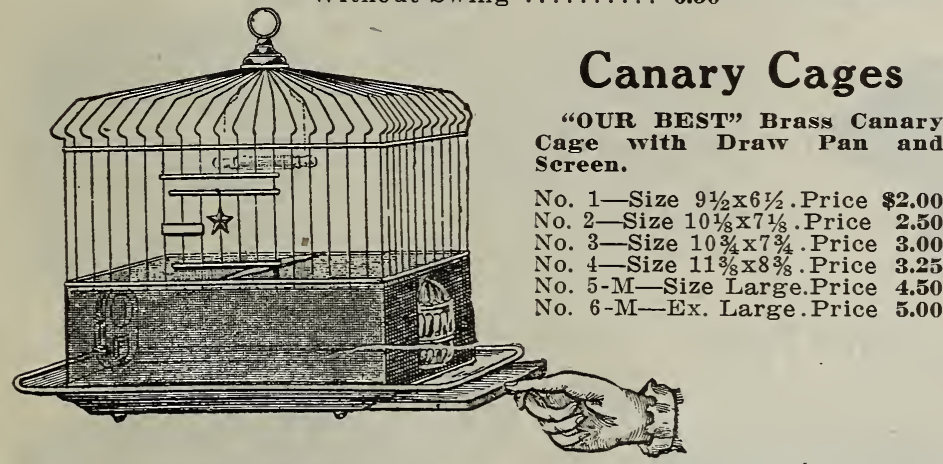

Japanned Cages

A beautiful pattern. Japanned and painted, very neat and attractive, though not as much so as the all brass kind.

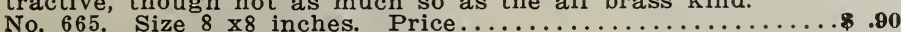

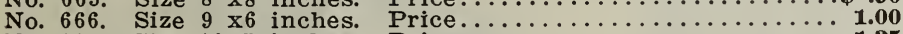

No. 667 . Size $10 \times 7$ inches. Price................

No. 668 . Size $11 \times 8$ inches. Price................

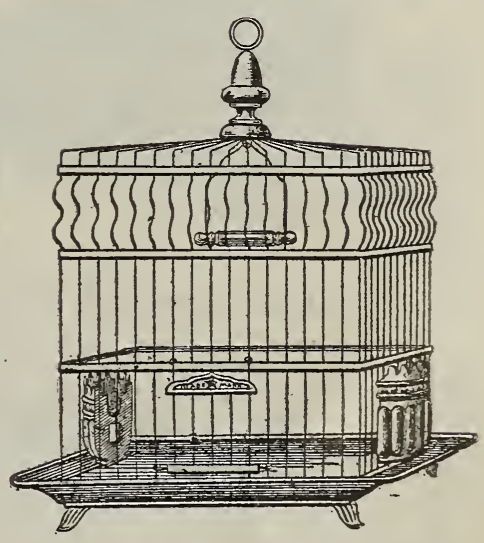

\section{Breeding Cages}

FLA'T TOP BREEDING CAGE.

This beautiful cage is well described by the accompanying illustration.

No. 1 Size 18 in. long. Price..........\$1.50

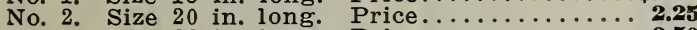

No. 3. Size 22 in. long. Price..................

NOTE-Wire nests and nesting should be ordered with this cage.

\section{Be sure to get the best foods for your bird}

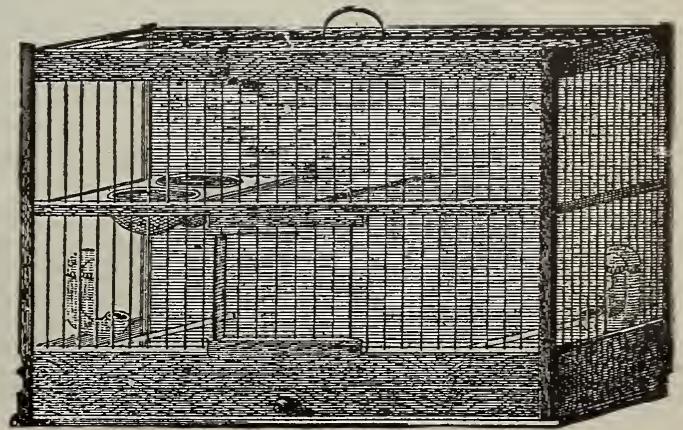




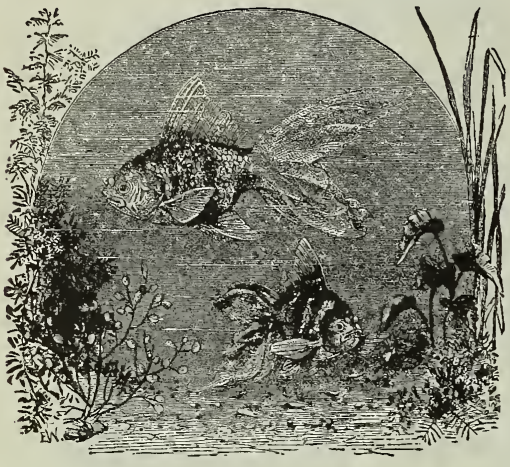

\section{Japanese Fantail Fish}

This variety is one of the most popular of all fancy fish, the fins and tail being of the finest lace-like formation with a tail of a V-shape. They are variegated in color, being of a golden-red, pearly-white and black coloring. We import this variety. direct from Japan. They are rather expensive, but if you want a fish that will beautify your aquarium, you cannot afford to be without this specie. Price each, according to size and coloring, \$1.50, \$2.00, \$2.50 and \$3.00.

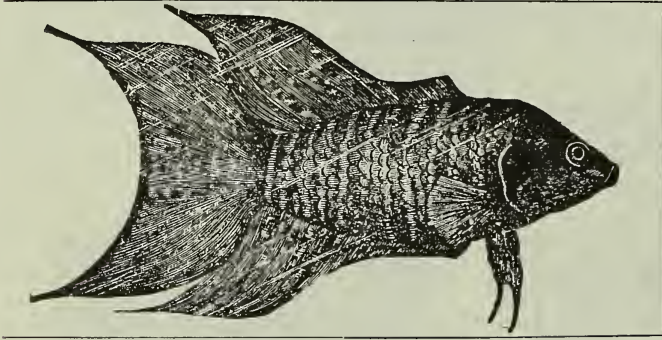

\section{Japanese Fringetail Fish}

Undoubtedly the most beautiful and gorgeous of all aquaria pets, having a handsome lace-like tail which shows as one ray of splendor when in nice clear water. The fins, like the tail, are very attractive. In fact, so beautiful are these pets of variegated colors that they often bring twenty-five to fifty times the price asked for other varieties. We offer specimens of superior shape and color at only $\$ 1.00, \$ 2.00$ and $\$ 3.00$ each, according to size.

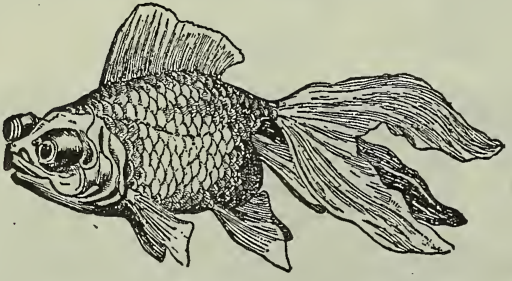

\section{Silver Fish or Pearl}

This fish is practically like the Golden Carp, only that they are of a white pearlish hue. They are used quite extensively for mixing in with other varieties in order to give the bowl or aquarium a beautiful effect. They are also very hardy. Prices each, according to size, 15e, 25e, 35e and 50e.
These fish are famous for their gorgeous tails, being spoken of by lovers of the finny tribe as "Long Tailed Beauties." They are without doubt the most graceful of all Gold Fish. These fish were formerly tives of Japan but, like Golden Carp, they are bred almost exclusively in this country now. No aquarium cies. Price each, according to size, 25e, 35e, 50 speand $\$ 1.00$.

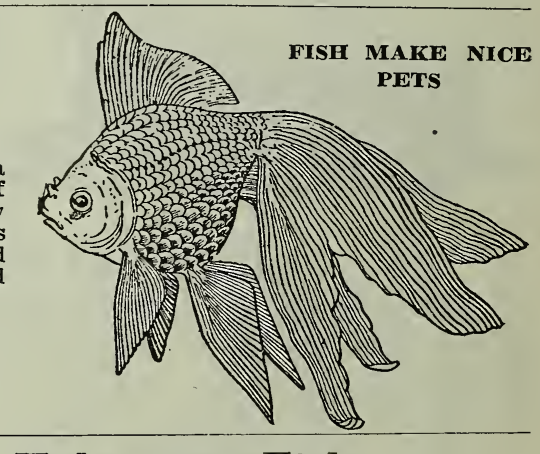

\section{Telescope Fish}

This is another native of the Chinese waters, noted for their oddity, having eyes that bulge out like telescopes. The tail is single, double and sometimes triple. This variety is very scarce owing to the great demand for them to finish out the aquaria, giving it the touch that will always attract attention. We can supply you with fine specimens of these fish at 50c, $75 \mathbf{c}, \mathbf{\$ 1 . 0 0}$ and $\mathbf{\$ 1 . 5 0}$ each, according to size. In color they resemble the ordinary Gold Fish.

\section{Tadpoles}

The scavenger of the aquaria. They consume all decay and refuse matter and aid greatly in keeping the fish healthy, 10e each, 75e per dozen. 


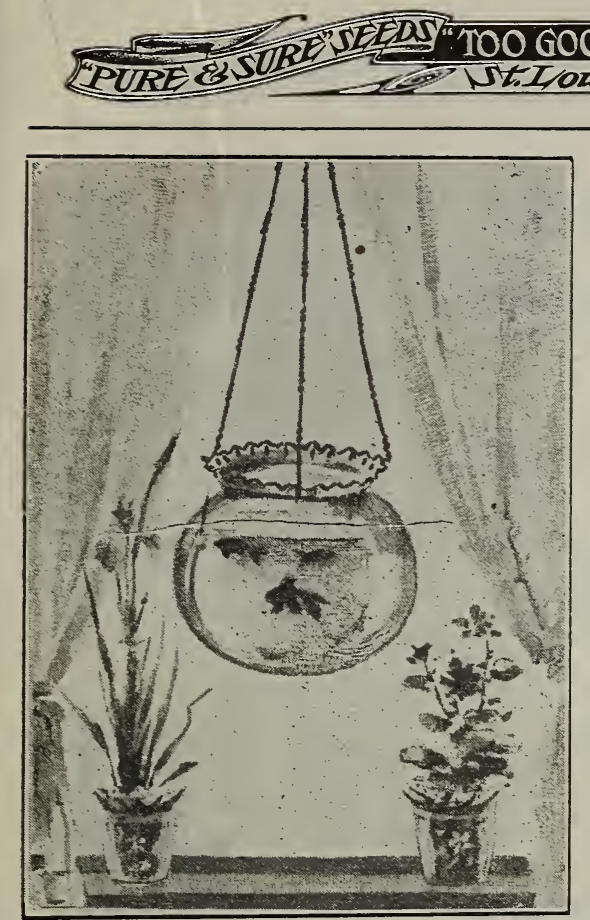

DECORATE YOUR HOME

\section{FISH GLOBES AQUARIUMS}

All of our globes are made from pure lead glass and are extra heavy.

\section{LOW OR HANGING FISH GLOBE.}

These are the most popular of all globes.

Diameter. Holds. Each. Diameter. Holds. Each. 7 -inch.... 3 qts....\$0.50 10-inch....8 qts....\$0.90

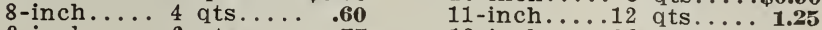

9 -inch ....6. 6 qts..... $\mathbf{7 5} \quad 12$-inch.....16 qts.... 1.75

\section{GLASS TANIK.}

These beautiful aquariums are made of heavy glass. Being of a green and bluish hue, they give the water a very pretty effect, in fact, making it look like sea water. They are very much admired and give the fish plenty of room in which to play. Size, 3 quarts up. Each 90e to \$4.00.

\section{SHEE'T IRON FRAME AQUARIUM.}

This beautiful aquarium has slate bottom, the corners being lined so as to avoid the water coming in contact with the frame. They are neat, durable. Prices: No. 1, \$2.50; No. $2, \$ 4.00$. $\$ 5.50$.

Same with glass bottom. No. 1 , \$2.50; No. $2, \$ 4.00 ;$ No. 3 ,

IRON FRAME AQUARIUM. SLATE BOTTOM.

The ideal aquarium for displaying fish in Public Places. The smaller sizes are elegant for home use. They are the most durable aquarium made. Hence they are the most popular. No. $3,19 \times 10 \times 11 \frac{1}{2}$ inches, each $\$ 10.00$.
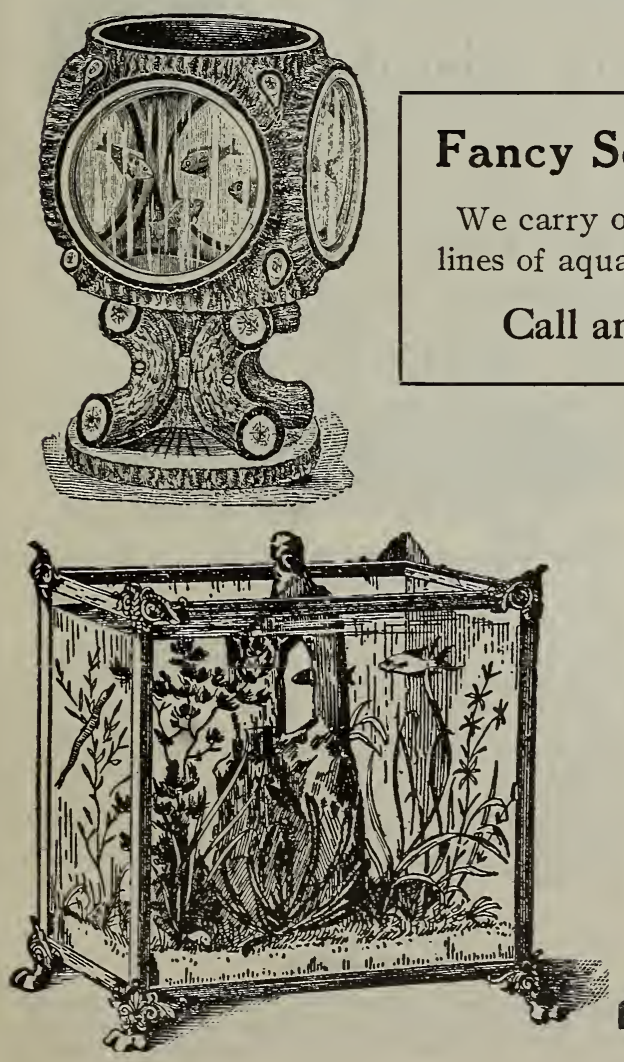

\section{Fancy Square Aquariums}

We carry one of the most complete lines of aquariums in the country.

Call and see our display
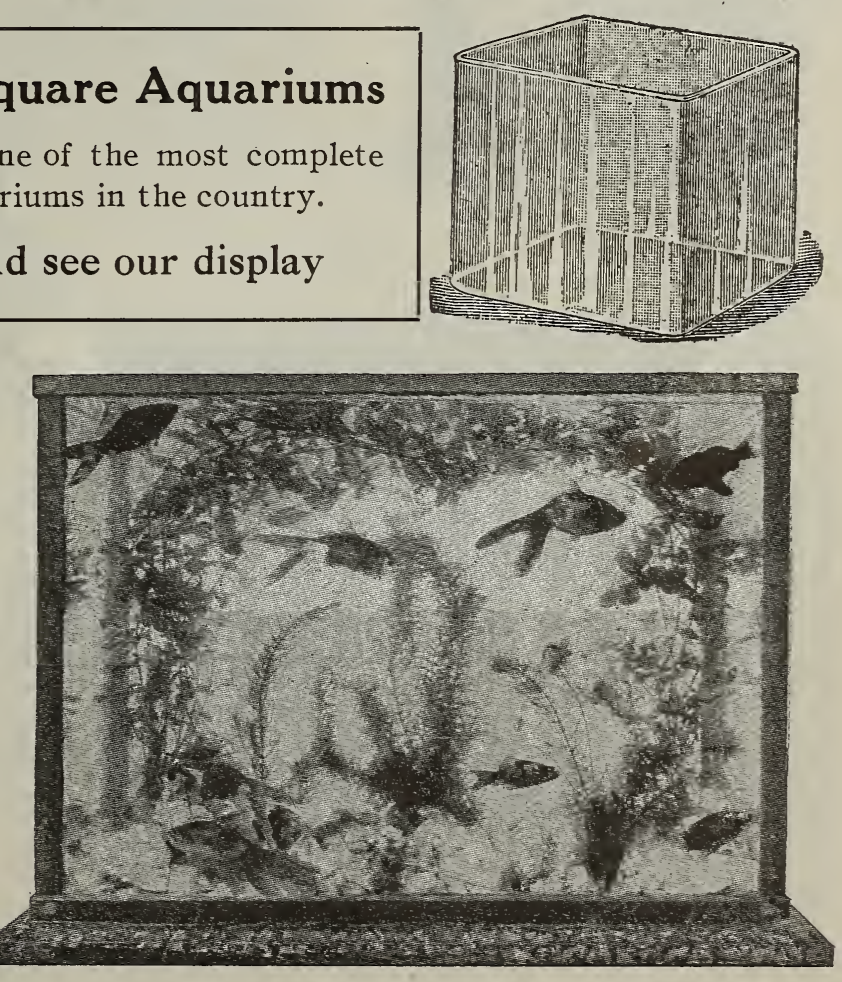


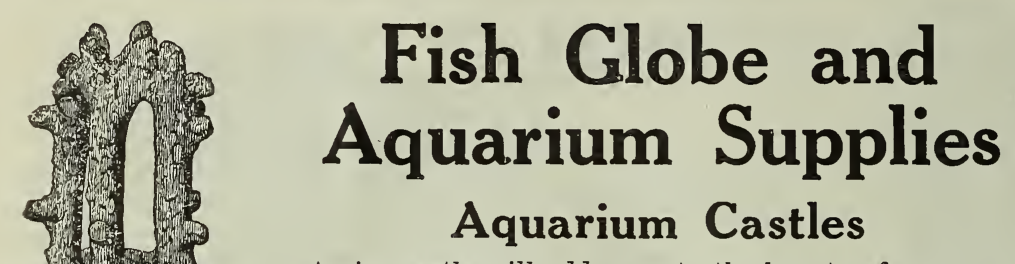

A nice castle will add more to the beauty of an aquarium or fish globe than anything else you can choose. We carry many different designs in stock, ranging in prices from $10 \mathrm{c}$ to $\$ 3.00$ each. If you desire a castle ornament we will strive our utmost to choose a design that will merit your approval and set off the bowl or aquarium whichever you may order.

\section{Single Ruin}
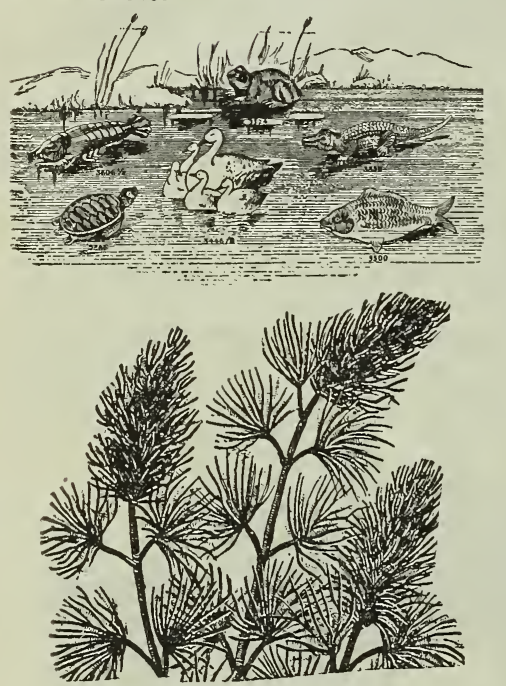

Aquaria Moss or Cabomba

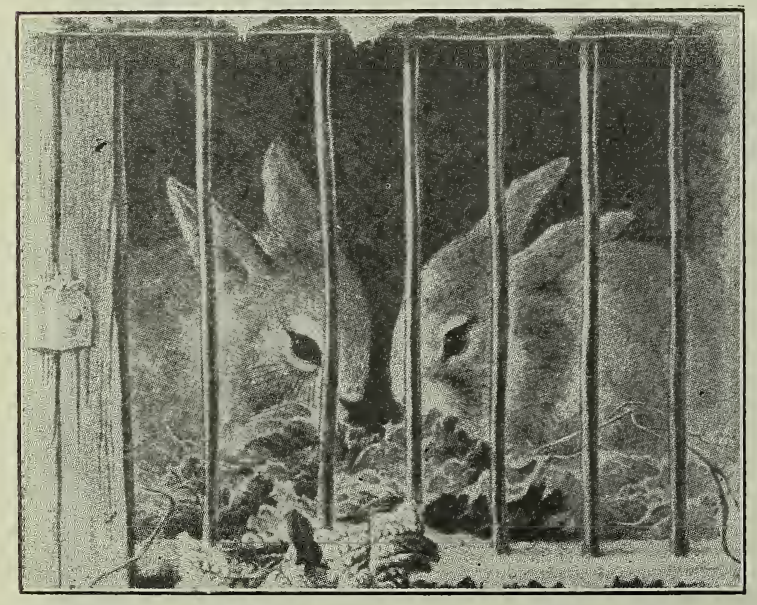

A handsome design representing the remaining ruins of an old castle. The fish enjoy swimming through and around the old relic. Very attractive. 7 in. high. Price, each, 40c.

\section{Grotto}

The most popular of all castles. The fish can swim through and around it, as it does not take up so much space in the bowl. Price, each, 3 in. high, 10e; 4 in. high, 15e; 5 in. high, 20e; 6 in. high, 40e; 7 in. high, s0c.

\section{Light House}

One of the most popular designs made, representing an ocean lighthouse, and when magnified by the aquarium glass looks very pretty. Price, each, 5 in. high, 75e; 8 in. high, \$1.25.

\section{Aquaria Moss or Cabomba}

One of the most valuable plants for the aquarium, also the prettiest. Fish enjoy eating it. It adds health and beauty to any aquarium. Price, per bunch, 10c. box, $15 c$. per quart, 15e. pint, 25e; per quart, 40c. per box, 10c.

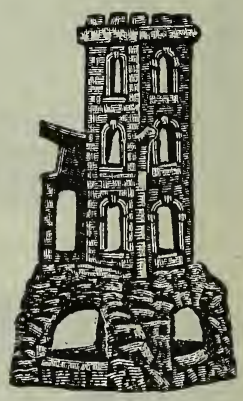

Single Ruin

Light House

\section{Fish Food and Supplies}

Imported German Granulated Fish Food contains all ingredients of animal life, which is necessary to obtain the full breeding vitality of the fish and keep it in good health. Price, per

Imported Ant Eggs, greatly relished by fish and all aquarium inhabitants, should be fed once a month. Price, per packet, 10c.

White Gravel, prepared especially for aquariums. Fish enjoy playing in it, as it produces the river bottom effect. Price, per pint, 10e;

Assorted Shells.-Fancy assortment of assorted shells adds beauty to the bowl, or aquarium, also helps to keep the fish healthy. Price, per

Rubber Hose, used for siphoning water to and from the aquarium, also convenient for having around the house to siphon cider, vinegar, etc., from barrels. Price, per ft., 15c.

Dip Nets.-Used for taking fish out of aquarium while cleaning, also handy for picking refuse out of water. Net is attached to wire form, wooden handle. Price, each, 25e and 50c.

Fish Food Wafers should be fed in connection with the above composition. Each box contains enough food to feed 2 fish six months. Price,

\section{Rabbits}

We always have an extra fine lot of White Baby, Angora and Common Rabbits, all colors, for Easter time. See us when in need of them. 


\section{BIRD AND DOG SUPPLIES}

ST. ANDREASBERG SPECIAL MIXED BIRD SEED.

Prepared from fan cleaned and air dried, Sicily and Canary Seed, together with Rape, etc., per 1b. 15e; 2 lbs. 25c.

"TAPECANARY" SPECIAL.

A mixture of Rape and Canary Seed that contains a quantity of healthful compositions, very beneficial to either old or young birds. Per 1b. 10c; 3 1bs. 25e.

\section{Parrot Supplies}

\section{PARROT FOOD.}

Mixed sunflower and hemp seed, an ideal food for "Polly." Price, 1 lb. 10c; 3 lbs. 25e; 14 lbs. $\$ 1.00$.

\section{MAMIOTH RUSSIAN SUN FLOWER SEED.}

1 lb. 10c; 3 lbs. 25e; 15 lbs. \$1.00.

\section{FANCY PARROT PEANUTS.}

\section{(Selected Stock.)}

Price, 1 lb. 10c; 10 lbs. \$1.00.

\section{MEXICAN GRANOOD.}

A specially select composition of several kinds of vegetable and animal foods combined; it takes the place of cracker or soaked bread, it is greatly relished by Parrots and keeps them in good plumage, it is similar to the Parrot's native foods. Be sure and order some for your Parrot. Price, per lb. 25e.

\section{PARROT GRIT.}

A composition of Iron Tonic, ground and pulverized especially for Parrots and all large birds; it imparts vigor, robust and good health, and is very effective in warding off disease. Price, per lb. 10c; 12 lbs. \$1.00.

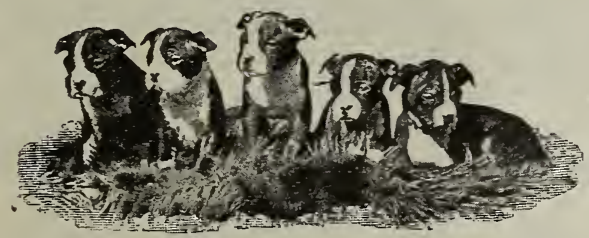

\section{Dog Supplies}

SPRATT'S DOG CAKES.

A composition of specially prepared food in cake form, medicated and adapted for grown dogs. Price, per lb. 10c; 3 lbs. 25e.

\section{SPRAT'T'S PATENT PUPPY CAKES.}

For puppies only. Lb. 10c.

Dog Remedies, Mange Cure, Etc., 50c and Up.

$$
\text { "FLEE-FLEA" SOAP. }
$$

Prepared expressly for bathing fancy dogs, cats and all domestic animals, a sure death to vermin. Price, per cake, 25c.

NOTE.-If you are interested in dog supplies write us for our special book, it gives full information regarding foods, medicine, etc. Mailed free for the asking.
S. L. S. CO.'S MIXED BIRD SEED WITH HEMP.

A highly valuable restora. tive, good for song birds of all kinds, of American bred birds only. Per 1b., 10e; 3 lbs., 25e.

\section{CUTTLE BONE.}

Do not fail to feed your bird Cuttle Bone, it is as important to the Canary as salt is to the human being, ours is the genuine Treiste Bone. Price, each, with holder, 5c.

SONG RESTORER.

In this composition we of fer a combination food and tonic as well as a song restorer combined; it should be fed during a cold or moulting season, in fact it is ideal to feed at any time. Per pkg. 15.c.

SONG RESTORER.

A restorer for weak and sickly birds. Feed to healthy birds once a week. It will keep them in full song. Per bottle, 25c.

\section{BIRD TONIC.}

A valuable remedy for all song birds, - invigorating. It should be given to canaries often in order to keep them in perfect singing order. Per bottle, 25c.

\section{BIRD TREAT.}

A nutritious bird food having medicinal properties which are very beneficial, as well as being enjoyed by the bird. Price, per package, 10c.

\section{MEAL WORMS.}

Should be fed to all cage birds occasionally, greatly relished by Canaries. Price, per $100,40 c$.

ST. L. S. CO.'S "SCRATCHAGUD" BIRD GRAVEL.

Prepared especially for $\mathrm{Ca}$ naries and other cage birds, it assists digestion and should be freely sprinkled over the bottom of the cage. Price, per package, 10c.

\section{GRAVEL PAPER.}

A composition similar to above, only it is made up like sand paper, very novel and clean, fits in bottom of cage. Per pkg. of 12 sheets, 20c.

MOCKING BIRD FOOD.

Prepared from a formula of our own, it is very invigorating to Canaries as well as to Mocking Birds; it contains a great amount of nutriment in condensed form. We handle only bulk stock. Per lb. 25e.

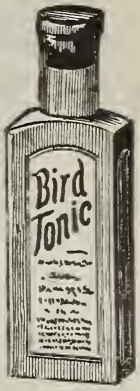

Bird Tonic

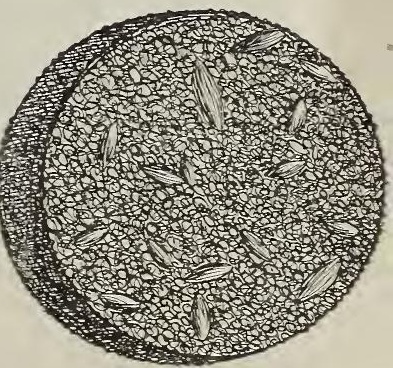

Bird Treat

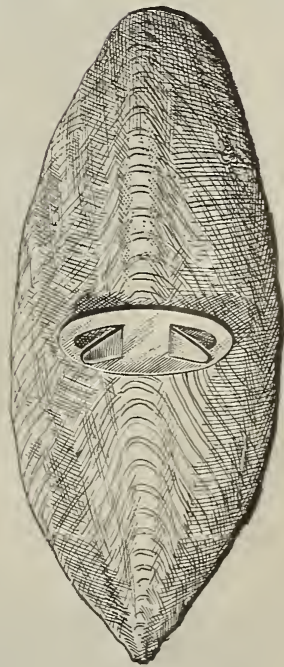

Cuttle Bone, with Holder

"Feedagud" BIRD FOOD AND YOU WILC "Havagud" Bird See Page 92 
Everything FOR THE

Poultryman

ass

Pigeon Fancier

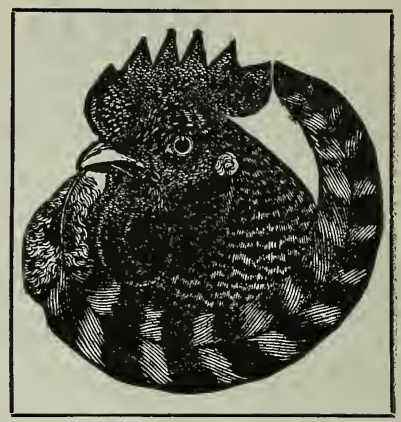

\section{On the following pages you will find a complete line}

\section{of supplies below and many others}

Petaluma Incubators

Mandy Lee Incubators

Buckeye Incubators

Cycle Hatcher

Brooder Hatcher

Petaluma Brooders

$$
\begin{aligned}
& \text { Mandy Lee Brooders } \\
& \text { Metal Mothers } \\
& \text { Philo Coops }
\end{aligned}
$$

Feed-a-Gud Foods

Poultry Feeders

Poultry Fountains

Chick Feeders

Bone Mills

Lice Killing Machine

Egg Carriers

\section{All Poultry Remedies \\ Poultry, Eggs and Chicks}

For many years we have handled Fancy Poultry as well as supplies and have on hand at all times thoroughbred Poultry of all the leading varieties, settings of Eggs, day-old Chicks and day-old Ducklings in season. We guarantee everything we handle as being just as represented. In our Poultry Department we employ skilled men only that are at all times pleased to give any information or suggestions that you may want.

You will find all articles that we catalogue to be standard goods, the best of each kind, and when we sell you these we feel that you will be satisfied.

Many losses are sustained by the Poultry raiser by feeding improper feeds that contain inferior grain and screenings. We guarantee our Feed-a-Gud Foods to contain sweet, fresh grain and to be absolutely free from screenings.

\section{Our Special Delivery Service}

On all Poultry orders amounting to $\$ 2.50$ or over we deliver free to any suburban station, or where our wagon express delivers we will deliver to your house. Oyster shell and grit excepted, unless accompanied with general order.

Within the city limits we deliver free all orders amounting to $\$ 1.00$ or over. This does not apply to goods sold at wholesale.

\section{TRY OUR POULTRY FOODS AND BE CONVINCED ON QUALITY AND RESULTS}




\section{PETALUMA INCUBATORS AND BROODERS STANDARD OF THE WORLD}

\section{Models for 1911}

Gold medals of the Louisiana Purchase Exposition and the Lewis and Clark Exposition and grand prize at the AlaskaYukon-Pacific Exposition were awarded to Petaluma Incubators and Brooders.

Certain others are claiming similar honors, but these honors were conferred upon Petaluma Incubators and Brooders, "Standard of the World." More gold, silver and bronze medals, certificates of merit and diplomas have been awarded to Petaluma Incubators and Brooders at the large expositions of the world than to any others.

Our Petaluma Incubators as shown in this catalogue are the latest improved, embodying all that is new in point of construction and efficiency.

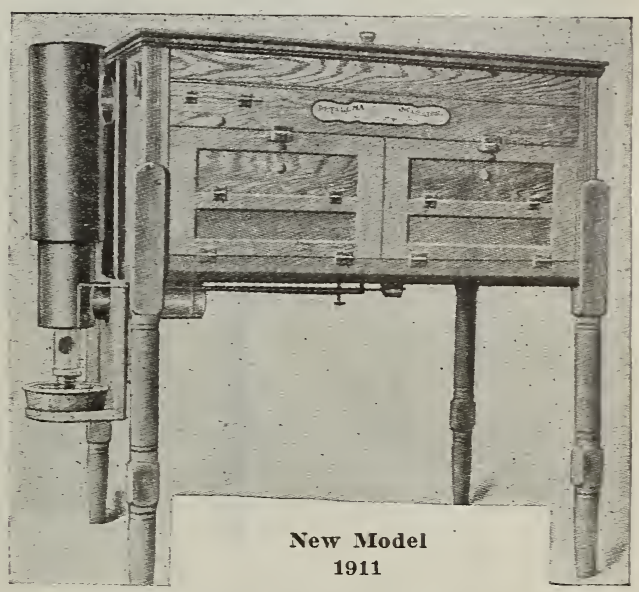

Model 80-126 Eggs

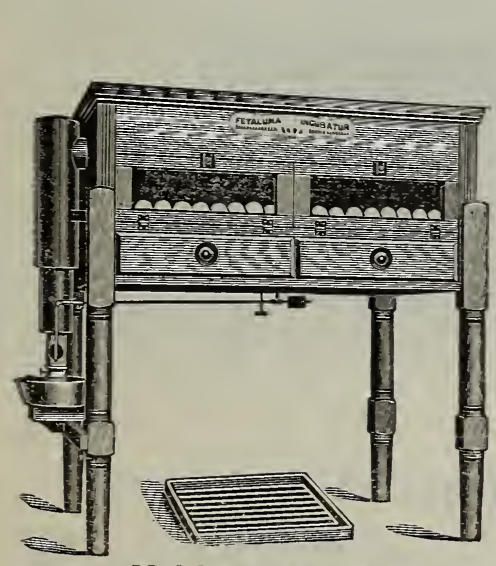

Models of 1910

These machines had a big run last season and many will want more of them this season, as they gave perfect satisfaction.

It will be seen that they are designated by model numbers. In the models $59,80,81,82$ and 83 the regulator acts on the flame to raise and lower it, which is well known to be the most economical in consumption of oil.

Model 59 , capacity 54 eggs............................. \$10.00

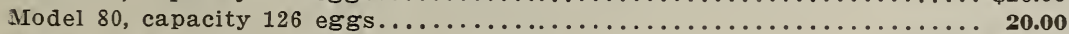

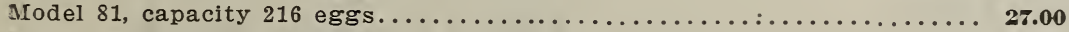

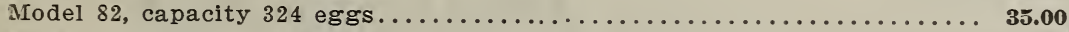

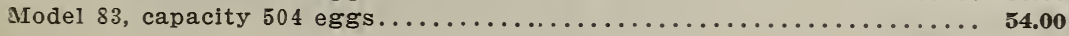

Above machines are operated with hot air.

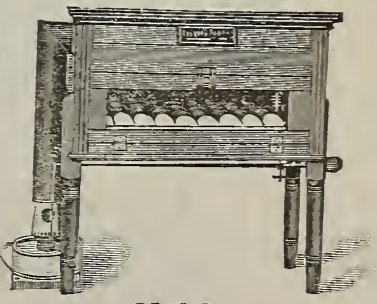

Model $\mathbf{5 9}$ 


\section{Incubators-continued}

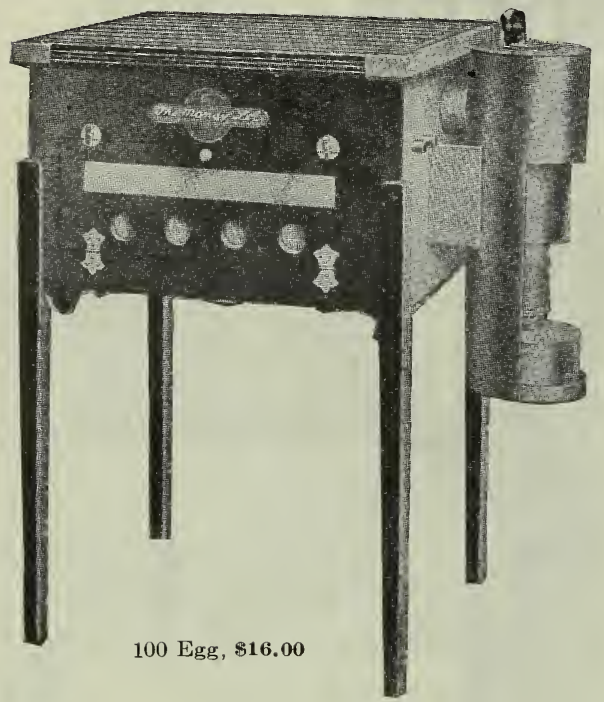

\section{The New Mandy Lee}

The Mandy Lee is constructed of air-dried California Redwood. We have found that this wood is the best for incubator use as it does not readily crack, warp, or shrink.

Heat, Moisture and Ventilation are the important factors in hatching eggs. If these three things are right, the hatch is always good provided good fertile eggs are used.

The packins in walls and top of the Mandy Lee varies from $11 / 4$ to $\mathbf{3}$ inches of mineral wool and asbestos, insulators of heat and protectors against fire. The packing of walls and top of an incubator is of utmost importance. Many incubators of the cheaper varity, and even some more expensive ones have no packing at all in walls or top except perhaps a sheet or two of asbestos paper or rosin paper and with the heating pipes running directly through the outer wooden walls.

FREE SPECIAL CATALOG ON MANDY LEE INCUBATORS

Prices:

$100 \mathrm{Egg} \ldots \ldots \ldots \ldots \ldots \$ 16.00 \quad 200 \quad \mathrm{Egg} \ldots \ldots \ldots \ldots \ldots \$ \ldots 25.00$

140 Egg......... 20.00 280 Egg........

\section{Buckeye Incubators}

\section{Style "C"}

Here is a fine little machine for the amateur. Holds 50 eggs, and a hot-water machine; can be used on table or shelf; it has short legs to support lamp, resting on table; it is well worth the money. Nicely finished and all ready for use. Price, \$6.00.
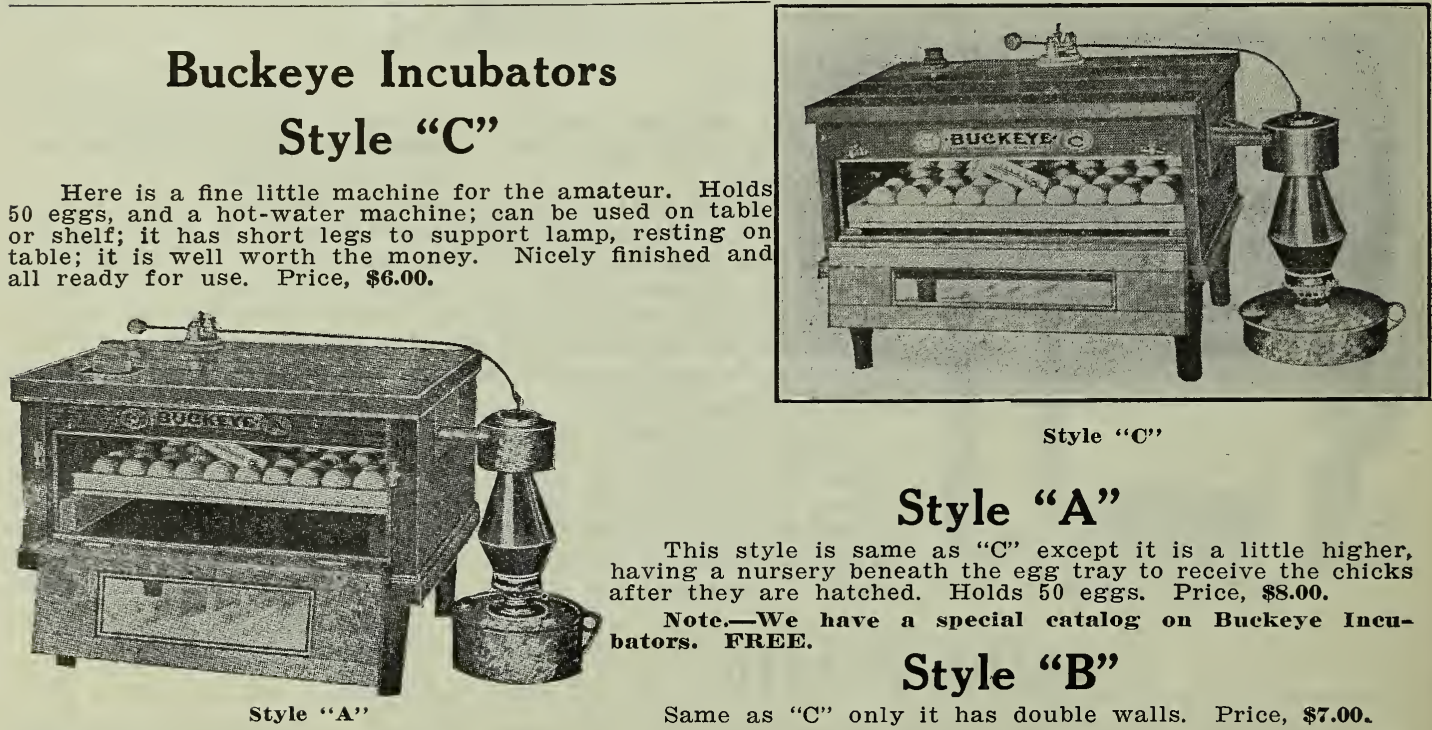

Style “ $\mathbf{C} "$

\section{Style "A"}

This style is same as " $C$ " except it is a little higher, having a nursery beneath the egg tray to receive the chicks after they are hatched. Holds 50 eggs. Price, \$8.00.

Note.-We have a special catalog on Buckeye Incubators. FREE.

\section{Style "B"}

Same as "C" only it has double walls. Price, $\$ \mathbf{\$ 7 . 0 0}$.

\section{Philo System}

We carry a full line of this system. We can save you money and freight charges.

\section{Cycle Hatchers}

All complete, \$6.00.

\section{Brooder Hatchers}

All complete, \$8.00.

\section{Sash for "Economy Coops"}

Separate without glass, \$1.00 each; 6 for $\$ 5.00$. Each, with glass, \$1.35; 6 for $\$ \mathbf{\$ 6 . 8 0}$.

\section{Philo System Book}

and Poultry Review for \$1.00.

Send for Free Catalog. 


\section{Mandy Lee Brooder No. 1}

\section{LAMP-HEATED-INDOOR USE ONLY.}

Generally Known as The Regular Brooder.

The Mandy Lee Brooder is, of outside dimensions, $\mathbf{3 x 4}$ feet in size. It is as large as any 200-chick brooder on the market, but we call it only 100-chick size.

The Hover is long and narrow, with a curtain along both sides, and a heavy blanket bottom which curves down almost to the floor in the middle. This blanket is heated on the upper side by the heating pipes which pass through the hover box. It is heated to about the temperature of a hen's body-a few degrees more or less don't matter-and the chicks go under from either side and nestle against the warm body of this artificial hen. Price, \$12.00.

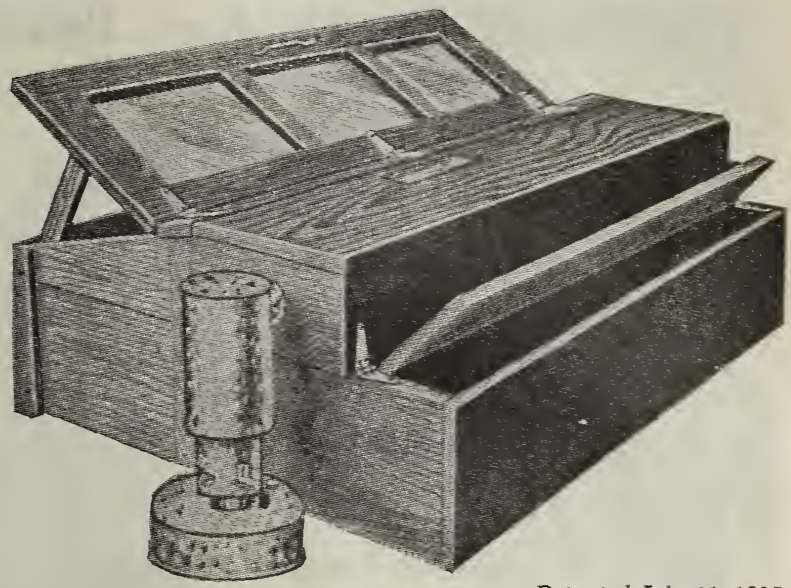

Patented July 11, 1905. Other patents pending.

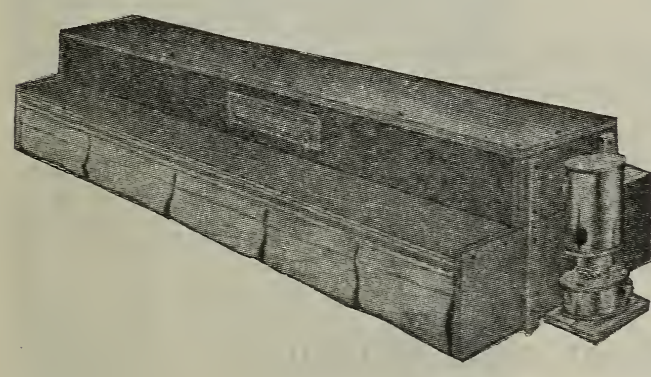

Capacity, 100 to 150 chicks, 4-weeks-old size. Dimensions (inches) $60 \times 23 \times 17$.

Floor Space Required (inches) 60x23.

\section{The Secondary Brooder}

This Secondary Brooder is, like our regular Mandy Lee Brooder, a very economical machine to operate. In ordinary spring and summer weather little, if any, lamp heat is needed, as fifty or one hundred lusty growing chicks snugly stowed away with a warm blanket on their backs furnish plenty of heat in their own bodies. Artificial heat must, however, be used at times, in cold weather or on chilly, damp days, and with the Mandy Lee Brooders the heating lamp may be used or not used as found necessary.

It is simply a mother for the chicks that are too large for the ordinary brooder but not old enough to "hustle for themselves" during damp weather or cool nights.

It can be used anywhere-in a poultry-house, barn, shed, piano box-just so it is protected from wind and storm.

Once used this brooder is almost indispensable. It seems to fit into a place no other brooder can occupy. One of our Pennsylvania admirers describes it as the "missing link," as it satisfactorily provides for those chicks "just out" of other brooders. Price each, \$7.50.

\section{Mandy Lee Fireless Brooder}

The Adjustable Hover on the Mandy Lee Fireless Brooder enables the handling of this temperature adjustment conveniently and without considering too frequently the number of chicks in the brooder. If the chicks in the brooder are apparently too warm the Hover may be raised more or less and if too cool the Hover can be lowered.

This does not have to be done very erequently. It is only when the outside temperature changes materially that such adjustment needs to be made.

100 -chick size..............\$5.00 200 -chick size...............8.00

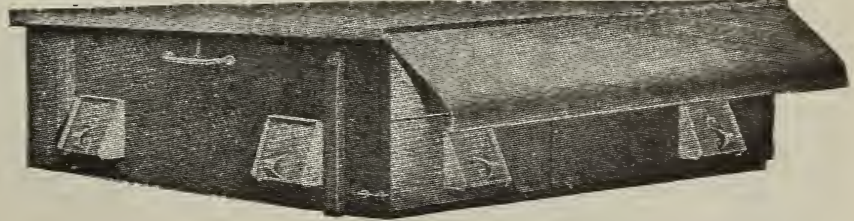

Mandy Lee Fireless Brooder-Closed 


\section{The Mandy Lee Outdoor, Heated and Regulated Brooder}

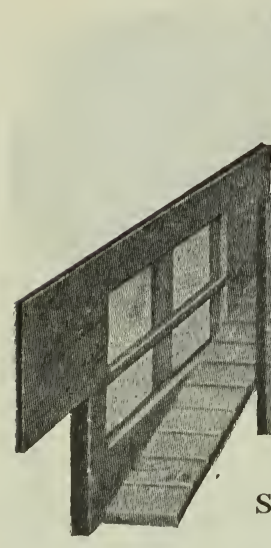

FRONT RAISEDShowing Hover, Run. way, and Exercising Room.

\section{BEST OUT-DOOR BROODER MADE} ment.

The Lamp is in an ample separate compart-

Then there is the Regulator, fust as in an incubator. The regulator takes care of the changes between a hover empty and a hover full of chicks; between hot days and cold nights.
Most such brooders of the present day are simply wooden boxes enclosing a lamp, the hover comprising one-half or more of the brooder, so that the chicks are as crowded when feeding as when under the hover which, in most cases, is merely another and muss highly-heated compartment.

The Mandy Lee Outdoor Brooder is not merely an outdoor brooder; it is a Brooder, Brooder-House, Colony-House, and, later, a complete ChickenHouse capable of caring properly for a pen or yard of birds.

Instead of the usual single floor of 2x4 feet with half of that comprising a sleeping compartment and intended to accommodate a hundred or more chicks we have a double floor $\mathbf{3 \times 4}$ and $\mathbf{3 \times 5}$ feet, the lower floor being directly on the ground where the chicks come in contact with mother earth even in most inclement weather. We have the Mandy Lee contact heat under a warm blanket-a long. narrow hover with curtain on both sides-just like our regular brooder-just like the old mother hen.

Both upper and lower compartments are lighted by a large double window. If desired, the hover can later be removed and the brooder converted into a two-floored Colony-House of from 24 to 30 square feet of floor space, a roosting place for many young fowl. Price: $3 \times 4$ feet, \$16.00; $3 \times 5$ feet, $\$ 18.00$.

\section{Petaluma Brooders-Indoor and Outdoor}

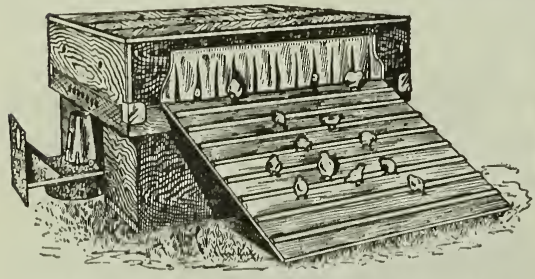

Models 23, 25 and 28. Indoor Brooders

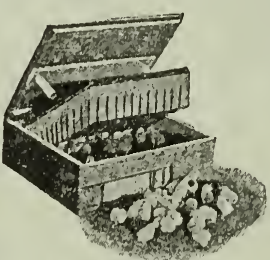

Models 3 and 4

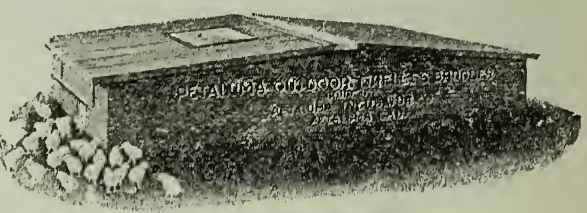

Outdoor. Model 5

\section{THE OUTDOOR FIRE BROODERS}

Are equipped with the proper heating capacity. For ventilation, convenience in handling, economy in oil and real worth it is superior to any other brooder for a similar purpose to be found. Its use insures satisfactory results, and that is what the poultrymen are seeking.

\section{PETALUMA FIRELESS BROODERS}

The heat accumulator is suspended from hooks, front and back, and is instantly removable. When top cover is removed the chicks are not disturbed nor warmth lost. When chicks grow large and do not require the heat accumulator the brooders can be used as a well-ventilated night hover, the ventilating features not being disturbed by removal of the heat accumulator.
Model 23, 100-chick capacity..........\$8.00 Model 25, 150-chick capacity................... Model 28, 250-chick capacity............13.50

\section{OUTDOOR FIRE BROODERS}

Model 24, 75 to 100 chicks...........\$11.00 Model 26, 125 to 150 chicks............. 16.00
Our full lipe of brooders is shown in our large catalogue, which will be mailed free to anyone writing for it.

Model 3, Indoor, 100-chick capacity........\$6.00 Model 4, Indoor, 200 -chick capacity...............00 Model 5, Indoor and Outdoor, 100-chick capacity ...........................50 Model 6, Indoor and Outdoor, 150-chick ca-

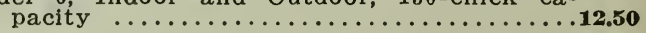




\section{Poultry for Breeding and Eggs for Hatching}

We are in a position to supply you with standard breeds of Poultry at all times. We will not attempt to give a full list of Poultry because of so many varieties, and quality or value depends upon the stock wanted. Please describe fully your wants and we will gladly quote you the lowest possible prices consistent with quality on any breed you want.

\section{WHITE LEGHORNS}

Price of stock Females, each $\mathbf{\$ 1 . 2 5}$ to $\mathbf{\$ 3 . 0 0}$. Males, $\mathbf{\$ 1 . 2 5}$ to \$3.00. Price of Eggs (15), Utility \$1.00; from Show Birds, \$2.00.

\section{BROWN LEGHORNS}

Price of Stock Female, each \$1.25 to \$3.00; Males, \$1.25 to \$3.00. Price of Eggs (15), Utility, \$1.00; from Show Birds, \$2.00. RHODE ISLAND REDS

Price of Stock Females, each $\$ 1.50$ to $\$ 5.00 ;$ Males, $\$ 2.00$ to \$5.00. Price of Eggs (15), Utility \$1.50; from Show Birds, \$2.50. BARRED ROCKS

Price of Stock Females \$1.25 to \$5.00; Males, \$2.00 to \$5.00. Price of Eggs (15), Utility \$1.50; from Show Birds, \$2.50.

WHITE ROCKS

Price of Stock Females, \$1.25 to \$5.00; Males, \$2.00 to \$5.00. Price of Eggs (15), Utility \$1.50; from Show Birds, \$2.50.

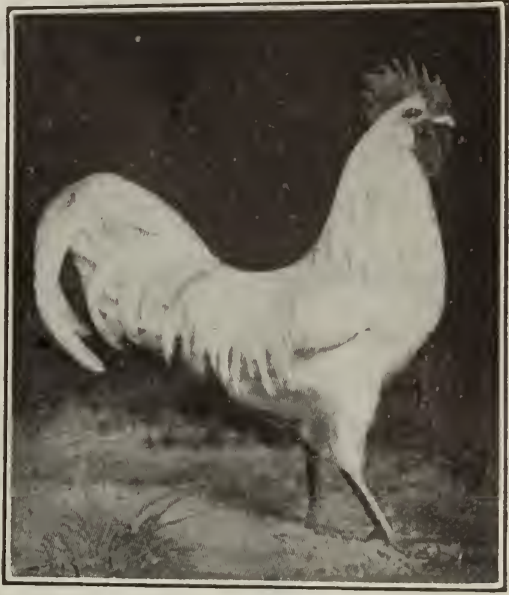

White Leghorn

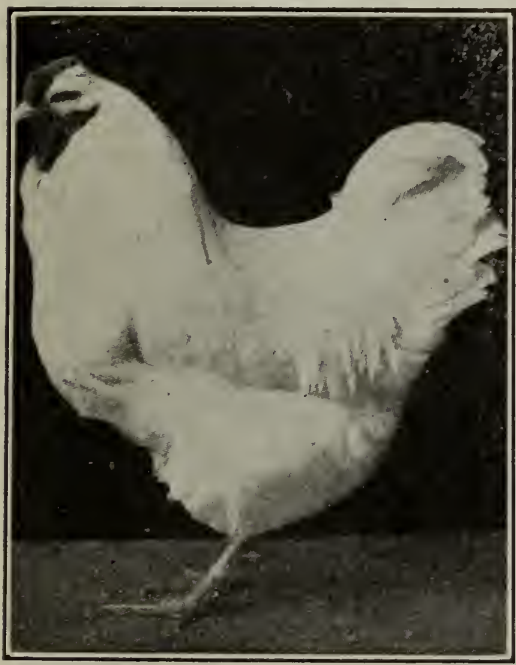

White Wyandotte

MAMMOTH TOULOUSE GEESE

Price of Stock Females, \$5.00; Males, \$5.00. EMBDEN GEESE

Price of Stock Females, \$5.00; Males, \$5.00. WHITE HOLLAND TURKEYS

Price of Stock Females, \$5.00; Males, \$5.00. MAMMOTH BRONZE TURKEYS

Price of Stock Females, \$5.00; Males, \$5.00. BOURBON RED TURKEYS

Price of Stock Females, \$5.00; Males, \$5.00.

\section{Baby Chicks and Ducklings}

Many people do not realize what amount of chicks can be raised in a small back yard, but we all know that homeraised and dressed poultry is better than the kind we get at the market. It takes very little labor and expense to raise a few dozen little chicks at home large enough for table use In season we offer Baby Chicks at \$1.50 per doz.; \$10.00 per 100. Ducklings $\$ 2.40$ per doz.
WHITE ORPINGTONS

Price of Stock Females, \$3.50 to \$10.00; Males, \$5.00 to \$25.00

BUFF ORPINGTONS

Price of Stock Females, \$2.00 to \$5.00; Males, \$2.00 to \$5.00. Utility \$2.00; from Show Birds, \$3.00.

WHITE WYANDOTTES

Price of Stock Females, \$1.50 to \$3.50; Males, \$2.00 to \$5.00.

Price of Stock Females, \$1.75 to \$4.00; Males, \$2.50 to \$5.00.

LIGHT

BLACK MINORCAS

males, \$2.00 to \$5.00; Males, \$3.00 to \$5.00.

ULACK LANGSHANS

SILVER LACED WYANDOTTES

Females, \$3.00 to \$5.00; Males, \$3.00 to \$.5.00. MAMMOTH PEKIN DUCKS

\section{INDIAN RUNNER DUCKS}

Price of Stock Females, \$2.50; Males, \$3.50. Price of Eggs 11), \$2.50.

WE HAVE THE LARGEST DISPLAY OF POULTRY AND SUPPLIES IN THE WEST

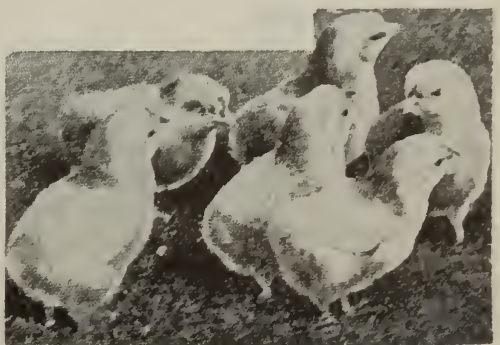




\section{Poultry Feed}

Price of Poultry Feed Subject to Change

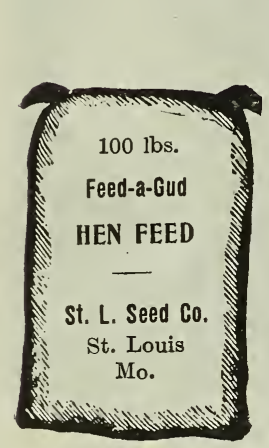

\section{"FEED-A-GUD" HEN FEED}

Our Feed-a-Gud Hen Feed, commonly called chicken feed, is made up of the proper mixed, sweet, fresh and sound grains, without screenings, dust and inferior grains; contains no grit and shell. It is all feed-no waste.

When we say it contains no shell and grit, we do not mean that shell and grit is waste, but we want to impress on your mind that we will sell you grit and shell at one-half price of hen feed. As - a rule grit and shell should be fed separately and not mixed with the feed. We also quote a hen feed that contains grit and shell at less cost, and quote you grit and shell less than one-half of the price of hen feed.

Chickens have no teeth, therefore they need grit to grind their food. Oyster shell contains a large per cent. of lime and makes egg shell.

4 lbs., 15e; 8 lbs., 25e; 25 lbs., 65e; 50 lbs., \$1.10; 100 lbs., \$2.00.

Feed-a-Gud Hen Feed with grit and shell, per 100 lbs., \$1.75. Special price on larger quantities.

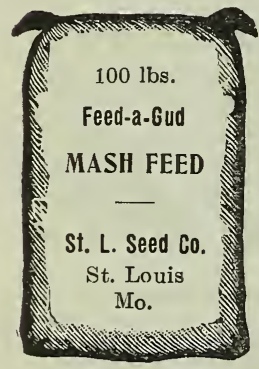

\section{"FEED-A-GUD" MASH FEED}

The Balanced Ration for Poultry-200 Eggs per Year

There is not, and never has been anything on the market to compare with it. The hen is a very accurate machine, and will convert egg-making material into eggs rapidly if given the right proportions of all such materials as are needed.

4 lbs. 15c; 8 lbs. 25c; 25 lbs. 70c; 50 lbs. $\$ 1.30$; 80 lbs. $\$ 2.00$.

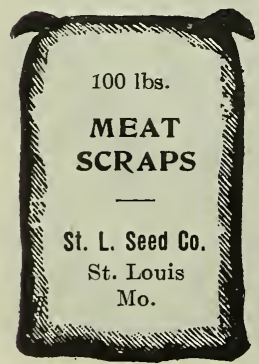

\section{MEAT SCRAPS}

Will insure an increase in eggs that will more than pay the cost. A great help in moulting season to prepare hens and pullets for winter laying.

5 lbs. 25e; 12 lbs. 55e; 25 lbs. \$1.10; 50 lbs. \$2.15; 100 lbs. $\$ 4.00$.

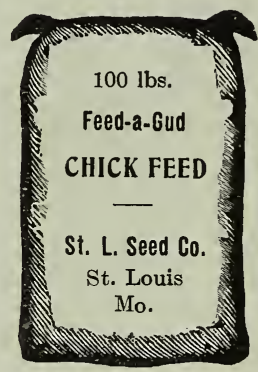

"FEED-A-GUD" CHICK FEED

Feed-a-Gud Chick Feed contains no shell and grit; is composed only of sound, wholesome grain carefully and scientifically balanced, so that it will meet all the requirements of maturing chicks and laying hens. No stale or damaged grain is ever used in preparing this feed. It is the best grain mixture upon the market and contains all the elements necessary in the grain line.

Feed-a-Gud Chick Feed, 4 lbs. 15e; 8 lbs. 25e; 25 lbs. 65e; 50 lbs. \$1.25; 100 lbs. \$2.25.

Feed-a-Gud Chick Feed with grit and shell, per 100 lbs., \$2.00.

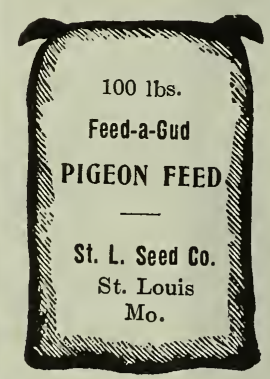

"FEED-A-GUD" PIGEON FEED

Feed-a-Gud Pigeon Feed contains no shell and grit. It is a scientifically prepared Balanced Ration Food. Especially adapted to the growth of young pigeons and squabs. It makes the best general feed for all kinds of Fancy and Domestic Pigeons. Keeps the birds healthy and develops shape, style and plumage to a remarkable degree. As a foundation food it has no equal.

"Feed-A-Gud" Pigeon Feed, 4 lbs. 15e; 8 lbs. 25c; 25 lbs. 65e; 50 lbs. \$1.10; 100 lbs. \$2.00.

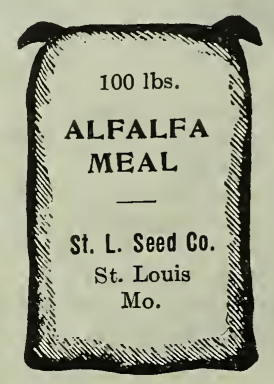

\section{ALFALFA MEAL \\ (Colorado Green)}

Is now one of the most essential Foods of the day for poultry as well as horses, cat. tle, etc. Our brand is the best that can be made; clean and nice, fine to mix with other feeds. It is a blood maker and egg producer. 5 lbs. 15e; 10 lbs. 25e; 50 lbs. \$1.10; 100 lbs. $\$ 2.00$.

\section{“FEED-A-GUD” FEED to HAVE-A-GUD CHICK}




\section{POULTRY FEED-Continued-Prices Subject to Change}

\section{MICA CRYSTAL GRIT}

Mica Grit contains valuable medical properties and acts as a medicine as well as a grit. This grit is made in two sizes for poultry, pigeons and small chickens. State whether you want coarse or fine when ordering.

5 lbs. 10c; 10 lbs. 15e; 25 lbs. 25c; 50 1bs. 45c; 100 1bs. 75c.

\section{FINE RAW CRACKED BONE}

It is ground very fine and is especially used to mix with a mash food.

5 lbs. 20c; 10 lbs. 35c; 25 lbs. 80c; 50 lbs. \$1.50; 100 lbs. \$3.00.

\section{COARSE CRACKED BONE}

Made of fresh green bone, is an excellent egs maker; used extensively by all poultry raisers.

5 lbs. 20c; 10 1bs. 35e; 25 lbs. 80c; 50 lbs. \$1.50; 100 lbs. \$3.00.

\section{OYSTER SHELL, CRUSHED}

This is made from nice bright oyster shells, not clam shells or mussel shells. This is the best egg shell producer

5 lbs. 10c; 10 lbs. 15c; 25 lbs. 25c; 50 lbs. 45e; 100 lbs. 75 .

\section{CRYS-CO}

Is a great shell producer, poultry food and grit all combined in one. 99 per cent. of pure carbonate of lime.

5 lbs. 10c; 10 lbs. 15c; 25 lbs. 25e; 50 lbs. 45e; 100 lbs. 75e.

\section{CHARCOAL}

Everyone should know the value of charcoal. It prevents sour crop and aids digestion; is beneficial to poultry of all ages. Made in two sizes. Fine for chicks and coarse for older poultry.

3 lbs. 15c; 6 lbs. 25c; 100 lbs. \$2.75.

\section{WHEAT BRAN}

Very essential to the poultry raiser. Best grade. 5 lbs. 20c; 10 lbs. 35e; 25 lbs. 55e; 50 lbs. 90c; 100 lbs. \$1.50.

\section{CRACKED CORN}

Best on the market. It pays to buy this in preference to using whole corn.

25 lbs. 50c; 50 lbs. S5e; 100 lbs. \$1.50.

For Pigeons, etc.

\section{CANADA PEAS}

6 lbs. 25e; 25 lbs. 90c; 50 lbs. \$1.85; 100 lbs. \$3.50.

\section{KAFFIR CORN For Poultry.}

Used largely for Pigeons and other mixtures. 10 lbs. 20c; 50 lbs. 95e; 100 lbs. \$1.60.

\section{STEEL CUT OATS}

Is the best feed for baby chicks, far better than wheat or corn, because it is kiln dried, pre-digested, therefore preventing young chicks from bowel trouble. Very economical to feed, because they are more nutritious than mixed grain, and no waste.

5 lbs. 25c; 25 lbs. \$1.00; 100 lbs. \$3.50.

\section{COTTON SEED MEAL}

An excellent stimulant for egg making, giving them good color. This meal is very rich, also used for live stock feeding.

5 lbs. 20c; 10 lbs. 35c; 25 lbs. 80c; 50 lbs. \$1.50; 100 lbs. \$3.00.

\section{CUT CLOVER}

This is made from best qualIty of red clover, cut fine to use in Brooders and pens for baby chicks as well as scratch pens for older chickens. They eat the fine leaves when they can't get grass.

5 lbs. 20c; 10 lbs. 35c; 25 lbs. 85e; 50 lbs. \$1.50; 100 lbs. \$2.75.

\section{FLAX SEED MEAL}

This meal is largely used in a mash feed for poultry during the moulting season and when chickens are out of condition. It is a great stimulant for bowel trouble, etc.

5 lbs. 20c; 10 lbs. 35e; 25 1bs. S0c; 50 lbs. \$1.50; 100 lbs. \$3.00.

\section{ROLLED OATS}

The best feed on earth for ducklings. Helps to keep them in a good healthy condition. Our customers use it in large quantities. It is pure and wholesome food, fit for table use. We could not begin to supply the demand last season.

5 lbs. 20c; 10 lbs. 35c; 25 lbs. 75c; 50 lbs. \$1.50; 100 lbs. \$3.00.

\section{HEMP SEED}

A very fattening food and well liked.

10 lbs. 50c; 25 1bs. \$1.25; 50 lbs. \$2.25; 100 lbs. $\$ 4.25$.

\section{BUCKWHEAT}

Good for mixing.

10 lbs. 35c; 50 lbs. \$1.50; 100 lbs. \$2.75.

$$
\text { OATS }
$$

Common, whole for feeding.

Bushel, 65c; 10 bushels, 60c.

$$
\text { MILLET }
$$

For a scratch feed.

10 lbs. 20c; 50 lbs. \$1.00; 100 lbs. \$1.75.
100 lbs.

STEEL CUT

OATS

St. L. Seed Co.

St. Louis,

Mo.

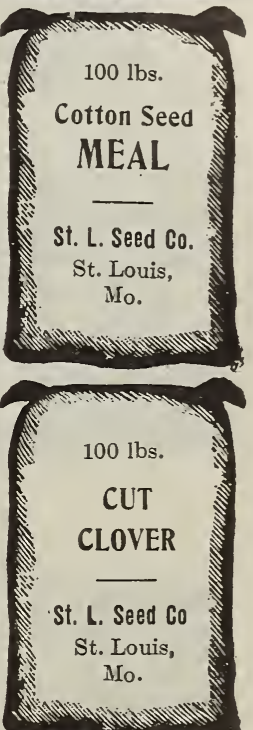

100 lbs.

Feed-A-Gud

Charcoal

St. L. Seed Co.

St. Louis,

Mo. 


\section{PURE 23 SURT}

\section{POULTRY REMEDIES-OUR GUARANTEE}

So positive are we of the wonderful curative powers of these remedies that we sell it to you with

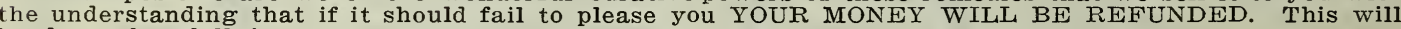
be done cheerfully!
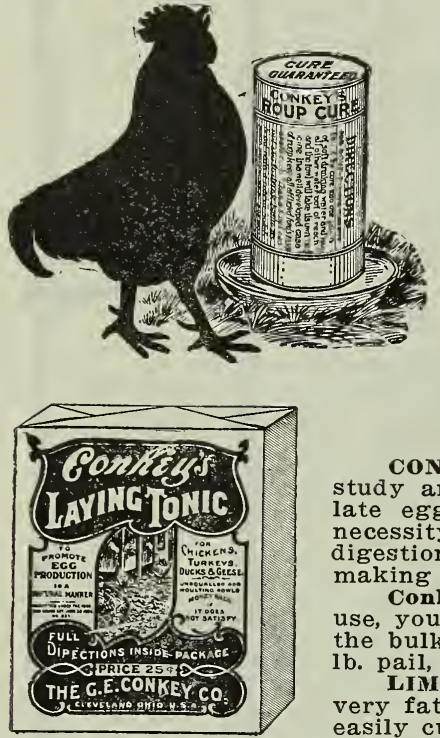

CONKEY'S ROUP REMEDY is a scientifically prepared medicine. Coming in contact with the membranes of the throat and mouth, the seat of the disease, it kills the germs which are so rapldly multiplying. It is quickly taken up by the system and, being a strong tonic and blood purifier, it cleanses the blood, builds up the system, and assists nature in every possible manner to throw off the disease.

Price 50c and \$1.00.

CHICKEN POX.-This disease is known by different names in different localities, such as Sore Head, Pigeon Pox, Warts and Pian. Chicken Pox is very contagious, and is a very annoying and disgusting disease. It is often called the Small Pox of the poultry yard. If allowed to run, it leads to weakness and death.

Symptoms.-Scabby warts on the comb, lobes and face. These are yellow and rough and resemble the common wart. Price, 50c.

CONIKEY'S LAYING TONIC is a result of years of careful study and experiment, and a properly-made tonic, to stimulate egg production in a common-sense manner, becomes a necessity. To keep the bowels in good condition, to assist digestion and the assimilation of egg-producing and strengthmaking material, to give vigor to the fowls.

Conkey's Laying Tonic is not a food in itself, and, in its use, you escape paying for bran and middlings which comprise the bulk of inferior "egg producers." Price 25c, 50c, \$1.00; 25 1b. pail, \$3.00.

LIMBER NECK. This is a ptomaine poisoning, and is a very fatal disease, requiring immediate treatment. It can be easily cured in all early stages. Price pkg., s0c.

CONKEY'S CHOLERA REMEDY.-We have put out this remedy in such a form that it must be given in the drinking water. As the fever creates a continuous and violent desire for water. Most of the so-called cholera remedies on the market are powders directed to be given in the food. Realizing the utter absurdity of trying to cure the fowl in that manner, owing to its abhorence of food, we have made it in such form that the fowl will take its own medicine as it is tasteless. Price, 25e and 50c.

CONKEY'S BRONCHITIS REMEDY. -While Bronchitis has the general appearance of Roup, it is a distinct disease which requires a special remedy. It is an inflammation of the membranes of the bronchial tubes, instead of the membranes of the nostrils and head passages. Price, 50c.

SCALLY LEG.-This disease is caused by a parasite working in and underneath the scales of the feet and legs. The scales are loosened and elevated by a powderous substance accumulating beneath them, which gradually spreads from the toes, up the legs. Price, 50c.

CONKEY'S RHEUMATIC REMEDY cures those lame and useless birds, tones the system limbers up the joints, and gets them into profit-paying condition in very short order. It is absolutely dependable, if used according to directions. Price, 50c.

CONKEY'S GAPE REMEDY. - This is a reliable remedy for this deadly and annoying disease. Many people have experimented with irritating powders, fumes, smoke, etc., but have found them not only ineffectual, but positively dangerous to the fowls. It is guaranteed to do the work and to satisfy YOU. Given occasionally in the feed, it will be found an excellent preventive. Price, 50c.

CONKEY'S POULTRY TONIC is a remedy especially valuable for fowls run down, off feed, recovering from disease, or during moult ing season. It is a general invigorator, quickly bringing birds to a normal condition. Price, 25e.

CONKEY'S POULTRY LAXATIVE.-A reliable laxative is of ten needed by itself. It is compounded for poultry especially, is always of the same strength, and does its work thoroughly without depleting the energy or usefulness of the fowl. Price, 25c.

CONKEY'S LICE POWDER is absolutely harmless to the fowl, and positive and instant death to the lice. Dust the fowls thoroughly every ten days, or two weeks, particularly during hot weather, as the nits will hatch after the old lice are killed. Is also excellent for lice and fleas on dogs, horses, hogs, etc. Price, 10c, 25c, 50c, \$1.00 packages.

NOTE_-On receipt of $4 \mathrm{c}$ in stamps we will mail Conkey's 72-page Book on Poultry Diseases. It describes the symptoms of all diseases.
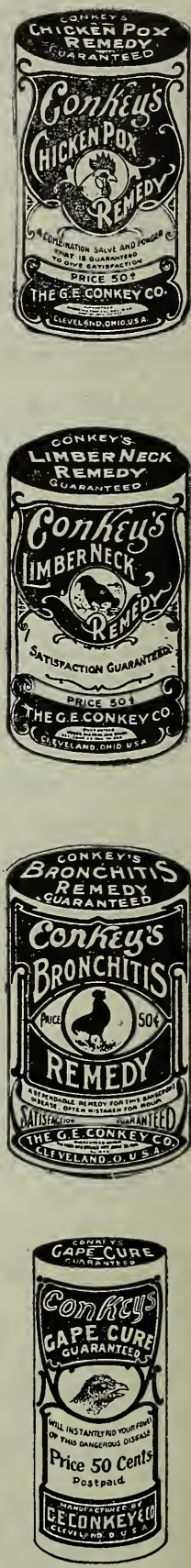

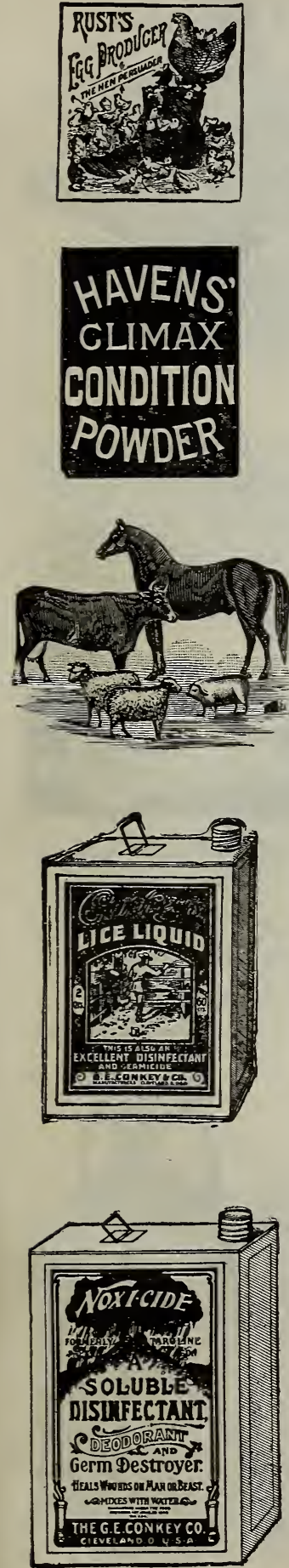

\section{POULTRYREMEDIES-Continued}

CONKEY'S HEAD LICE OINTMENT.-This article will destroy the head louse, which annually kills thousands of little chicks. Price, 10c and 25c.

CONKEY'S LICE LIQUID.-T'ine only thing for Mites. It kills them in the cracks, crevices and holes of poultry house, roosts and hiding places. It keeps your fowls free of one of their greatest pests. Prices, 1 quart, 35c; 2 quarts, 60c; 1 gallon, \$1.00.

CONKEY'S NOX-I-CIDE (formerly Taroline).-The greatest disinfectant and germ lestroyer known. One.gallon makes 101 gallons when ploperly mixed with water for use Prices, 1 pint, 35e; 1 quart, 60c: 2 quarts, 90c; 1 gallon, \$1.50. 50c.

CONKEY'S WHITE DIARRHOEA REMEDY.-Package

CONKEY'S POULTRY WORM REMEDY-Package, 50c. CONKEY'S SULPHUR CANDLES.For fumigating, 10c; 3 for 25 c. 25c.

CONKEY'S HEALING SALVE.-Nothing better. Price,

\section{CONKEY'S BLACK-HEAD REMEDY.-Price, 50c.}

\section{Conkey's Fly Knocker}

There is also a great loss to the horseman as it is difficult to keep horses in condition during fly time. The horse-shoer loses his own time, money, and floors, through the annoyance of fiies. It kills every fly it hits and keeps others from annoying the stock. Send for free literature on Flies and Fly Knocker. Prices, 1 quart, 35e; 2 quarts, 60c; 1 gallon, \$1.00; 5 gallons, \$4.00.

RUST'S HAVENS CLIMAX CONDITION POVVDER.-The only positive preventative and cure for gapes and poultry cholera. Price: 14-oz. packages, 25c; 32-oz., 50c; 5-1b. box (equal to six 25 c packages), \$1.00.

RUST'S HAVENS ROUP PILLS.-For the cure of roup, catarrh, cold and distemper. Price: Box, 25c and 50c.

RUST'S EGG PRODUCER.-This preparation supplies just what nature needs for producing eggs, plumage, growth and development, and in the exact proportions required. It imparts vitality so that the eggs surely hatch lively chickens. Price: 1-1b. package, 25c; 21/2-1b. package, 50c; 6-1b. package, \$1.00.

PRAT'S POULTRY REGULATOR AND CONDITION POWDER.-Trial packages: 26-oz., 25c; 4-1bs., 50c.

DR. HESS' POULTHY PAN-1-CE-A.-Webster defines it as a "universal remedy for diseases." Gapes, Cholera and Roup. It is an egg producer, by its invigorating effect upon the organs. Price, 25c and 60c.

LEE'S EGG MAKER.-Is largely granulated blood (deodorized), the most highly concentrated form of meat food, one pound of which is equal to 16 pounds of fresh meat, and with an actual tested protein feeding value in excess of 80 per cent. There is not one ounce of bran, sand, shell or other cheap and worthless filler in this product. It should be fed every month in the year to all penned-up poultry. Price, 25c, 50c; 25-1b. pail, \$2.00.

LEE'S INSECT POTVDER - What requires skill and knowledge is to make a preparation that will actually destroy vermin on an animal and with no injury to the animal itself.

Lee's product is a destroyer of vermin and absolutely harmless to the chick.

Prepared in large 11/4-1b. sprinkler-top cans and sell at $25 \mathrm{c}$ each.

LEE'S LIQUID LICE KILLER. -The kind that is always good; destroys all vermin-lice, mites, jiggers, bedbugs, etc., whether in the poultry house or on the bodies of the fowls, and does its work thoroughly and effectively. Price Quarts, 35c; 1/2 gallon, 60e; gallon, $\$ 1.00$.

\section{Germozone}

Is a wonder of the poultry world-the most popular poultry medicine ever placed on the market. The best preventive and cure for Roup, Cholera, Bowel Complaint, and other poultry diseases, most of which usually are fatal Given in the drinking water twice a week it cures disease, prevents contagion. Prepared in liquid form. Price, o0c.

NOTE-On receipt of $4 \mathrm{c}$ in stamps we will mail Conkey's 72. page book on Poultry Diseases. It describes the symptoms of all diseases.
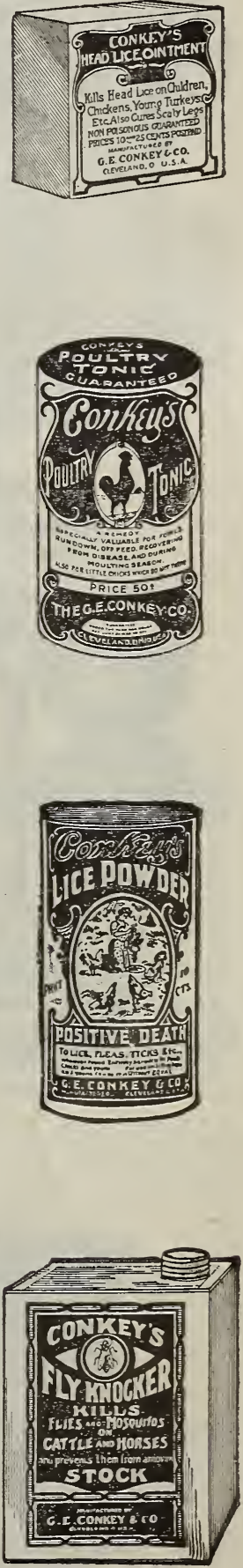


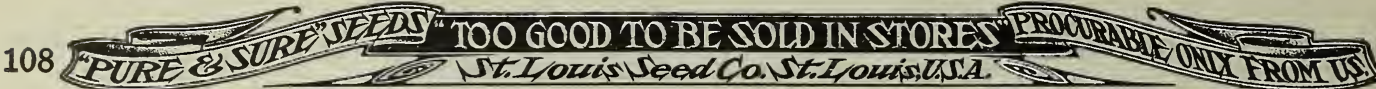

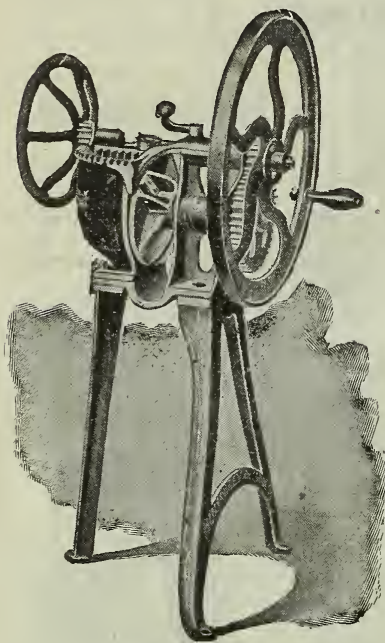

Humphrey

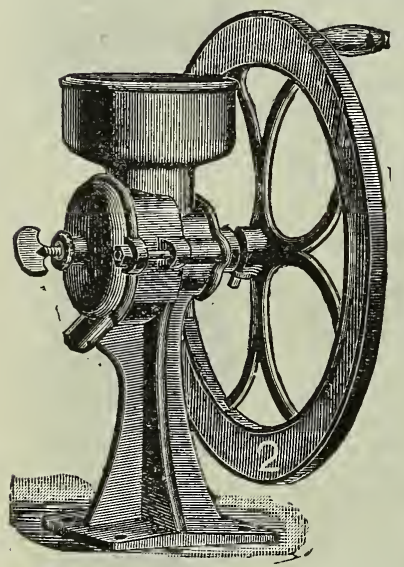

Model Mill

\section{POULTRY SUPPLIES}

HUMPHREY BONE CUTTER

We recommend the Humphrey. It is as small a machine as can be built on practical lines. The Humphrey is a more strongly built and heavier machine than any other selling at the same price. It has a large open hopper, ready for large bones at any time, and a heavy balance wheel. Four heavy corrugated knives (oil-tempered), bolted to cutter head. Immense clearance back of cutting knife makes clogging impossible. Price, \$12.00.

BLACIK HAWK CORN SHELLER.Chilled bearings and springs adjusted by thumb nut. Made largely of malleable iron; clamps easily to box. Will shell perfectly clean and throws cobs out. Black Hawk, weight 15 pounds. Price, each $\$ 2.00$.

MODEL GRINDING MILL. -They are intended to grind all kinds of grain, dry bone, shells, roots, bark, salt, etc.

LIST OF SIZES, WHIGHTS AND PRICES

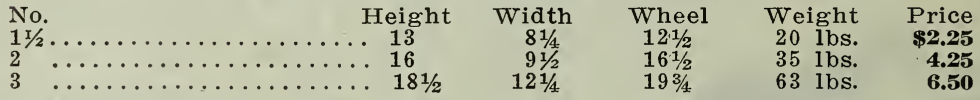

SCHILD'S LIGHTNING LICE-KILLING MACHINE

For Winter Eggs Use Schild's Lightning LiceKilling Machine

The Lightning Lice-Killing Machine will kil all lice that hide upon a fowl's body, under down or feathers, just as easy as it will kill those body lice on little chicks, under their fine, close down. It will clean as many as six to nine old fowls or 20 to 50 little chicks at one operation without the least injury. The No. 1 for small chicks and pigeons, are only $\mathbf{\$ 2 . 5 0}$ each; No. 2 for both chicks and old fowls, \$3.00 each, and No. 3, for Brahmas and turkeys, \$4.00 each. A $1 / 2-1 b$. can powder with each one you purchase.

\section{NORWICH FEEDER AND EXERCISER.}

They are the greatest feed and labor savers ever invented. Sparrows, rats and mice give them up in disgust. The chickens can always get just enough of any kind of dry feed placed in the hopper. The machine saves its cost in feed in 90 days, and saves its cost in labor several times a year. Fill the hopper once a week and the chickens do the rest. and the chickens do the rest. chickens learn to use it in thirty minutes. It is rain and rat proof. The price is very low: No. 1, 8 quarts, \$2.50Suitable for about 12 chickens. No. 2, 14 quarts, \$3.25Suitable for about 20 chickens.

\section{BLACK HAWK GRIST MILL}

The Black Hawk Grist Mill grinds corn, hominy and chicken food, wheat and rice; cracks peas for soups; grinds beans, coffee, spices, salt and makes buckwheat flour. Price complete, \$2.75.

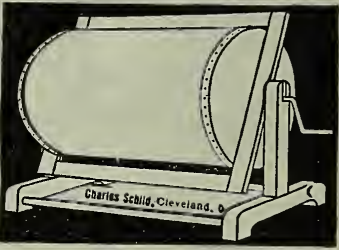

Lice Killing Machine

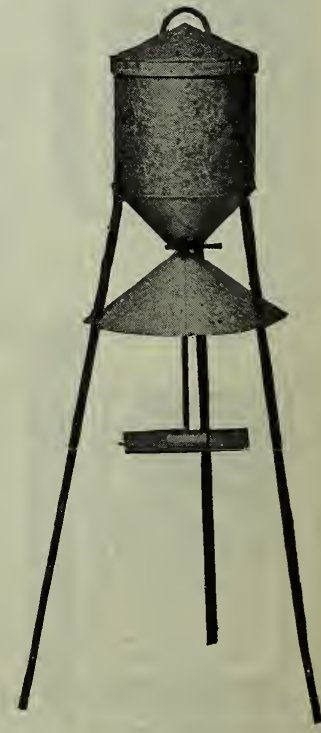

Norwich Feeder 


\section{POULTRY SUPPLIES-Continued}

"KNOX" MEDICATED NEST EGGS.-Perfect imitation of eggs composed of disinfectants that will drive away all mites, lice and other vermin. Price: Each 5e; 25 for \$1.15; 100 for \$4.00.

CHIX. NEST EGGS.-Fine for leaving in nests as they are exact duplicates of eggs. Price: 3 for 5e; per dozen 15e; gross \$1.65.

CHICKEN NESTS.-Wire, 1-inch mesh. Very desirable. No chance for vermin. Can be hooked or screwed to wall. Price: Each 15e; dozen $\$ 1.50$.

WOOD FIBRE NEST BOWLS.-Made in only one size (9-inch diameter Bowl). Have every merit of the old style wood bowl and are indestructible. Cannot warp or split, as many of the old style turned wood bowls do when made of timber poorly seasoned. Price: \$1.25 per dozen; \$10.00 per 100.

ANDERSON EGG BOX.-This box makes an admirable package for shipping fancy eggs. The eggs are surrounded by a double thickness of corrugated paper, which perfectly protects them from any injury. Prices: 1 sitting, No. 3 , 75 e per dozen; 2 sittings, No. $4, \$ 1.50$ per dozen; 50-egg size, No. 5, \$2.50 per dozen; 100-egg size, No. 6, \$4.00 per dozen.

FARMERS' FRIEND EGG CARRIER,-Is the most useful and convenient article that a farmer or poultryman can have. Each one will carry safely 12 dozen eggs. Price, 50c each.

HUMPTY DUMPTY EGG CARRIERS.-A light, cheap and durable egg carrier for shipping and hauling eggs to market. Folded in the flat ready to set up. Always shipped knocked down. Made to hold 12 dozen eggs. Each 35e; dozen \$3.75.

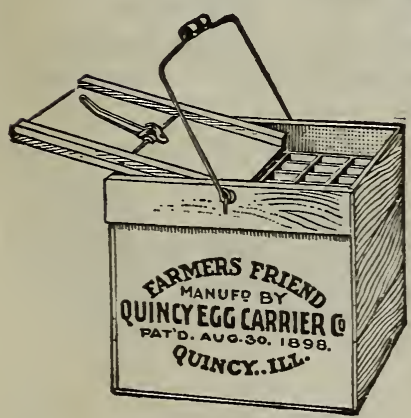

"HANDY" EGG CARRIER.These cartons are made of heavy cardboard, each holds 1 dozen eggs. Put up 250 in a bundle plain. 65e per 100; \$1.50 per 250; \$5.75 per 1000 . Charges for printing per 1000 \$1.00; 55e per 1000 for additional.

SAFETY SHIPPING COOP.Our coop, which we now manufacture, and for convenience and strength we are positive it is unequaled. The ends come attached to the bottom, so that in unpacking all that is necessary is to raise the ends upright, put in the sides, drive twelve small nails, and your coop is complete, ready for the birds in less than 2 minutes' time. Are entirely lined with strawboard, which protects from injury. Prices: For single

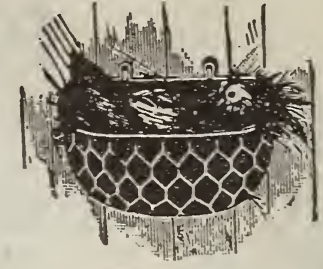

Wire Nest
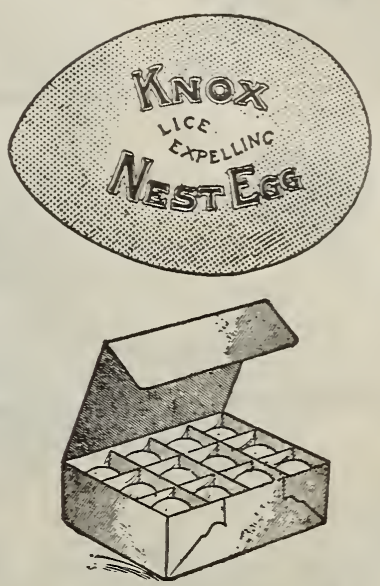

"Handy",

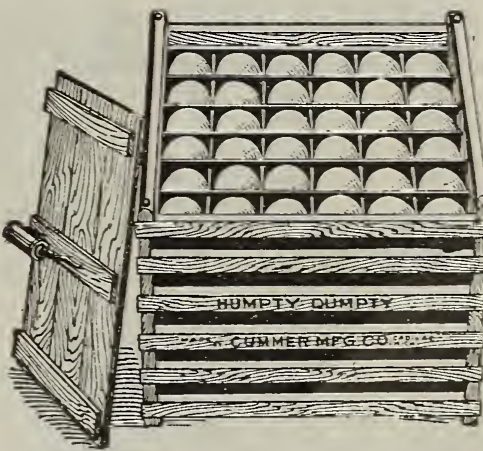

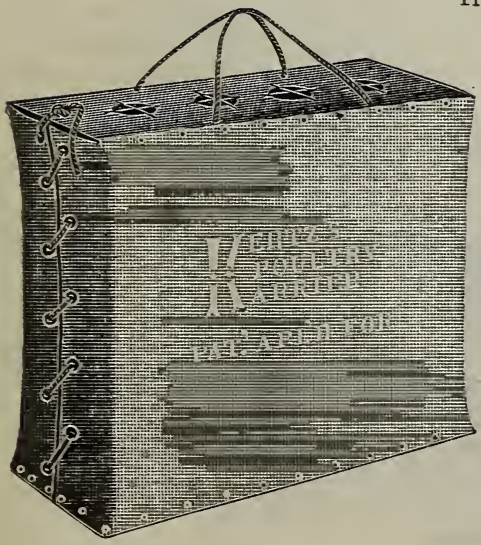

bir 12 inches wide 18 inches high, each 35c; dozen \$3.20. For pair or trio, 18 inches wide, 24 inches long and 20 inches high, each 50c; dozen \$4.60. For pen, 24 inches wide, 30 inches long and 20 inches high, each 65e; dozen \$5.S0.

\section{POULTRY CARRIERS}

Carry Your Pet Stock in a Safe Way

Poultry Carrier is made of canvas. The top and bottom are made of wood. The top hoard has holes with cross wire for ventimade of woour pet stock can rest comfortable. The sides and ends Width 7 inches, length 10 inches, height 8 inches, price 35c. No. 2: Width 7 inches, length 12 inches, height inches, price 3re. No. 2: Width 7 inches, length 14 inches, 10 inches, price 40c. No. 3: Width Width 7 inches, length 16 height 12 inches, price 50e. No. 4: Width 7 inches, length 16 inches, height 14 inches, price 55c. No. 5: Width 7 inches, length 18 inches, height 14 inches, price, price 75c. Special sizes made length 20

SEFTON LIVE CHICK BOXES.-Made of heavy corrugated paper with divisions to prevent chicks from crowding in shippaper Ready for use. Price: 100 chicks, size $24 \times 12 \times 5$, \$2.50 per doz; 50 chicks, size $12 \times 12 \times 5, \$ 1.50$ per doz.; 25 chicks, size $12 \times 6 \times 5$, $\$ 1.25$ per doz. 


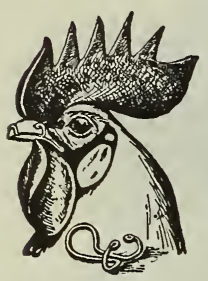

\section{Poultry Supplies (Continued)}

SCHILD'S LIGH'TNING POULTRY BIT

Our Lightning Poultry Bit is guaranteed to stop feather pulling the moment it is applied. It keeps the points of the fowl's bill just far enough apart so that it cannot grasp a feather. Does not interfere with eating or drinking, and does not spoil the appearance. Price: Each 10e; 3 for 25e; dozen, 75e.

\section{Our Daylight Egg Tester}

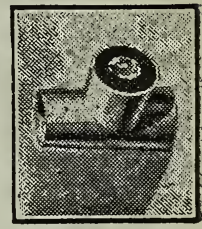

This is made of best quality of tin tapered at the bottom. Will fit either a No. 2 or 3 lamp. Each, 35c.
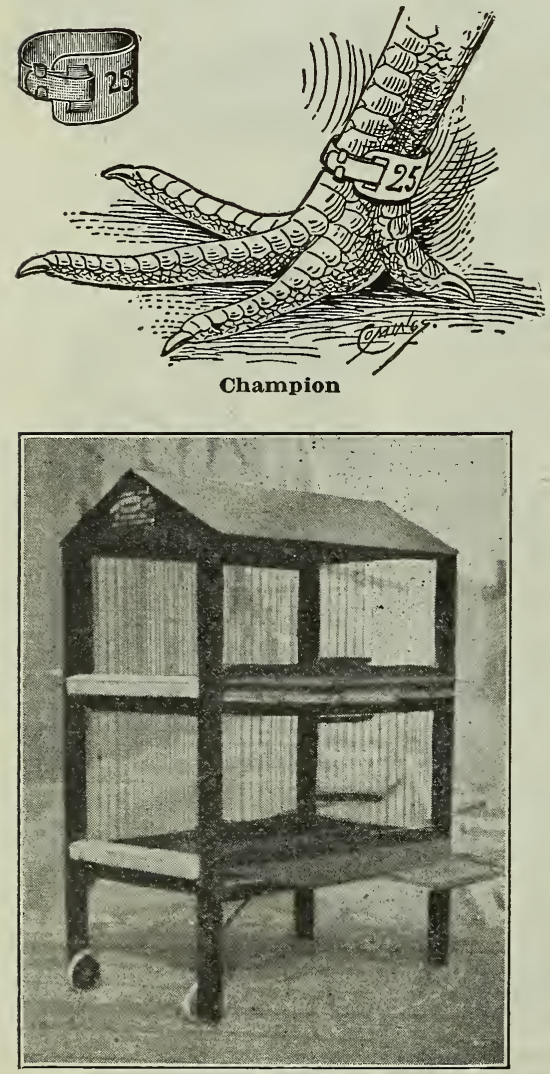

\section{Chicken Leg Band}

IMPROVED CHAMPION.-These bands never come off. Made of aluminum and numbered from 1 up. Always retain their color. (See cut.) Price: 12 for 15e; 25 for 25e; 50 for 45e; 100 for 65c. We also carry Pigeon Leg Bands. Prices same as Champion.

SMITH SEALED LEG BAND.-Made of copper or aluminum. (See cut for style and sizes.) When once they are sealed securely they cannot be removed unless cut off. These bands are numbered consecutively at the factory. No duplicates or plain bands can be had. We cannot supply any special numbers. Prices: 12 for 30e; 25 for 50c; 60 for $\$ 1.00 ; 100$ for $\$ 1.50 ; 250$ for $\$ 3.50 ; 500$ for $\$ 6.50 ; 1,000$ for $\$ 12.50$.

CHAMPION CHICK MARKER.-Makes a small hole in web of foot between toes. A very convenient punch. Price, 25e.

CAPONIZING INSTRUMENTS.-Furnished with full instructions, so that any one can easily perform the operation. Price, per set, \$2.50.

THERMOMETERS FOR INCUBATORS.-Tested. This style gives the tube the proper pitch, and the bulb rests on two eggs, thus insuring a correct temperature. Price, each 75 c.

All glass Thermometers $75 \mathrm{c}$ each.

Brooder Thermometers, 50c each.

PORTABLE DISPLAY COOP.-This coop is made of the best material; size of coop 30 inches wide, 48 inches long, 22 inches high. Each coop is fitted up with 2 feed troughs and 2 water pans, made of heavy galvanized iron. Each story has 2 galvanized drawers which are easily removed for cleaning. One inch above the drawers is a heavy removable wire grating which keeps the poultry's feed clean. For milk feeding, fattening and displaying poultry there is not a better coop made, on account of its many feed and water pans and sanitary conditions. Coop weighs 125 lbs. Twelve bolts are furnished, that being all that is needed to hold it together. Price, each \$15.00.

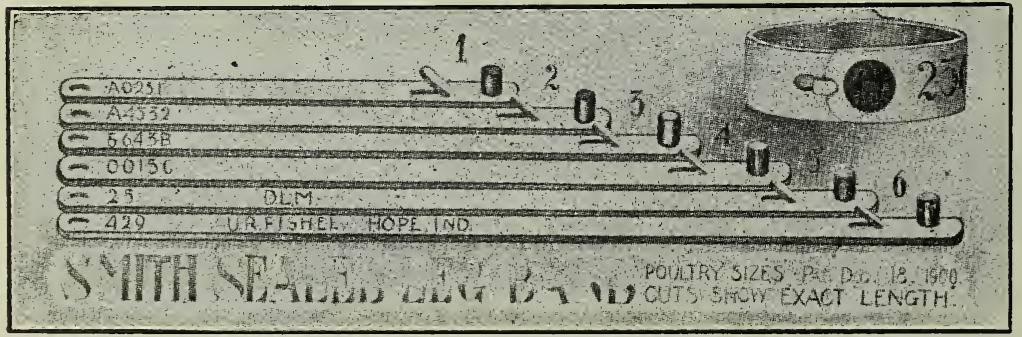

\section{SANITARY BROOD COOPS}

A galvanized iron sectional Coop. Water-proof, fire-proof, rat-proof. The only coop on the market that is strictly first-class. Size 17 inches wide, 17 inches high, 23 inches long. Price, \$2.25. Either flat or hip roof. 


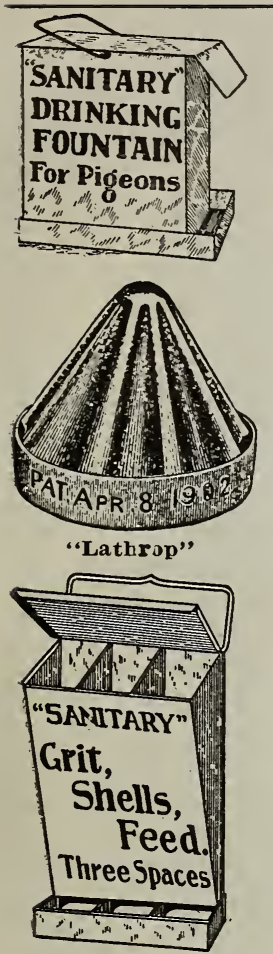

\section{POULTRY SUPPLIES-Continued \\ FEED PAN AND HEAD GREASER}

Nothing better for little chicks. The top pan being so constructed with oil wicks that during the eating and drinking process the head of the chick becomes thoroughly greased. A boon to poultry raisers. Price, 50c.

THE SANITARY CHICK FOUN'TAIN.-Our Sanitary Chick Fountain fits any brooder; stands five inches high; holds one quart. Its construction gives no chance for the little chicks to fall in and get drowned. The square base makes it impossible for it to tip over, therefore it is the safest fountain to use in your brooders. Price: 25c each; dozen \$2.75.

THE SANITARY POULTRY FOUNTAIN AND HEATER.This inexpensive combination placed in the house saves all trouble of thawing out drinking vessels and gives the poultry something warmer than ice water to drink. One filling of lamp will burn 72 hours. Very practical and no danger. It is the best, most convenient and durable fountain on the market. 1-gal. Sanitary Fountain, 50e; with heater, \$1.00. 2-gal. Sanitary Fountain, 85e; with heater, \$1.42.

\section{LATHROP}

Water and Feed Fount. The most convenient fount or feeder on the market. Only 6 inches high. Fine for brooders. Made of extra heavy galvanized iron. Very odd in appearance. Price each, 25e; 6 for \$1.35; 12 for $\$ \mathbf{2 . 5 0}$.

ATSA'T'T'S CHICIK FEEDER.-This is the neatest device ever invented for feeding young chicks. Chicks cannot get into it or stand on it. The top removes easily for cleaning or filling and is sprung back into place. Made of the best galvanized iron, so can be used either for wet or dry feed or water. Just the right size for the brooder, 10 inches long, 4 inches wide. Price, 25e; dozen, \$2.75.

"GRANT'S" A UTOMATIC FEEDER AND FOUNTAIN.

It feeds water, grain, grit, oyster shells, etc., and is the most Sanitary Fountain on the market; you can always see just how much water it contains without taking hold of it, and is so simple any child can fill it. Any size Mason glass jar fits it. We do not furnish the jars. Each

No. 1 Grit Box.

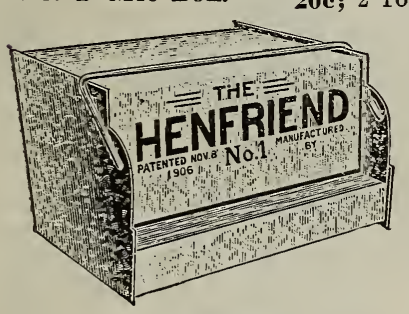

\section{FEED BOX}

These are the original Self-Feeding Boxes, being made of heavy galvanized iron, strongly riveted and well braced.

The feeders prevent

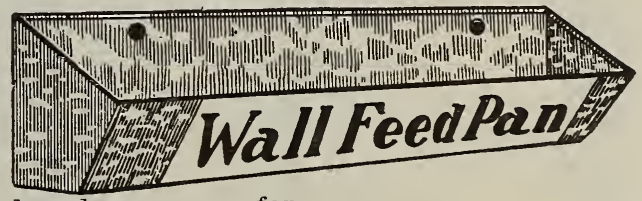
a large waste in the feed and soon pay for themselves. Price of No. 1 Grit Box, 50c; Price of No. 2 Grit Box, 2 partitions, 50c; dozen, \$5.50.

WALL FEED PANS.-Hangs on two naills Easy to clean. Saves waste. Always out of the way. Wet or dry feeds. 12 inch, 20e; doz. \$2.00; 18 inch 25e; doz. \$2.75; 24 inch 30e each; doz. \$3.25.

THE HEN FRIEND DRINKING FOUNT

Easy to clean, strong, cheap, durable and practical. Will not drown the chicks. Made of heavy galvanized iron. Can be used for feeding fountain also. Made in three sizes. No. 1, 2 gal., 75e each; dozen, \$6.50. No. 2,1 gal., 50c each; dozen, \$4.50. No. 3, 1 quart, 25c each; dozen, \$2.75.

EARTHEN BARREL FOUNTAINS

They will keep the water cool and clean and are so manufactured that it is impossible for chickens to get wet or drown while using them. Price: $1 / 2$ gal., 25e; 1 gal., 40e: 2 gal., 60e. them. PANITARY EARTHEN FOUNTAIN

This is made of stoneware, keeps the water cool in hot weather. Made in two parts; easy to be cleaned and filled. Will not rust or corrode when medicine is fed to chickens. Price: 1 quart, 20e; dozen, \$2.10, 2 quart, 25e; dozen, \$2.25. . 4 quart, 40c; dozen, \$2.50. 8 quart, 50e; dozen, \$4.50.

Can be used for feed or water holds any ordinary bottle or glass jar; made in two sizes, large for out doors, and small for brooders. Hang it on nail. Each 25e; dozen, \$2.75.

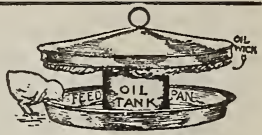

Head Greaser
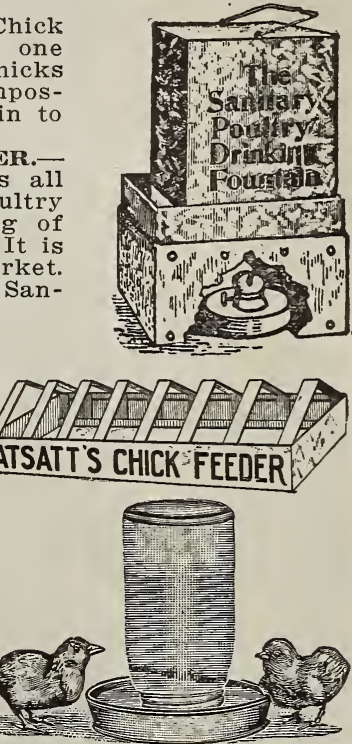

"Grant's" Fountain
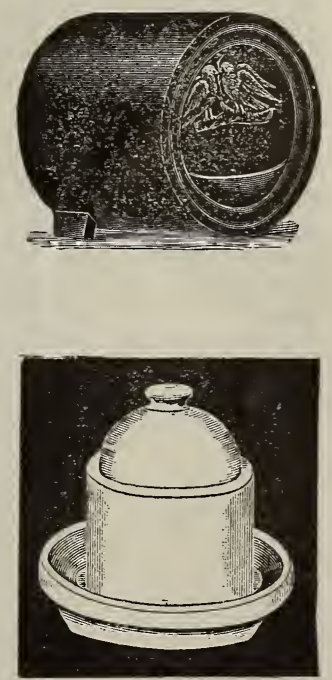

"Sanitary" Earthen 
GARDEN SEED

Artichoke.

Asparagus. .........

Beans.........1-2-10-11

Beets.............

Cabbage.

Carrots.....

Celeriac.

Celery.

Collards

Corn Salad .

Corn, Sweet.

Corn, Pop

Cucumber.

Cardoon.

Dandelion

Egg Plant.

Endive.

Herbs

Horse Radish

Kale.

Kohl Rabi.

Leek.... .

Mangels

Melon, Musk.

Melon, Water.

Mushroom Spawn

Mustard.

okra.

Onion Seed.

Onion Sets....

Parsley.

Parsnip .

Peas.

Pepper...

Radish

2-12 Chrysanthemum..

4-14 Cineraria...

4-14 Coxcomb

13 Coleus.

13 Columbine.

9 Cornflower.

9 Cornflower Aster.

Coreopsis.

3-13 Cosmos

8 Crimson Flax

$-15$

9 Dahlia.

9 Daisy, Double.

16 Daisy, Swan River

16 Datura.

20 Delphinium

15 Devil-in-a-Bush

15 Dianthus.

16 Dusty Miller.

18 Egyptian Rose.

5-17 Eschscholtzia.

12 Euphorbia

6-19 Everlasting page

27 Fern Spores..

18 Feverfew...

18 Floss Flower.

20 Flowering Flax.

20 Flowering Sage.

18 Forget-Me-Not.

2 Four O'clock..

-21 Foxglove.

22 Gaillardia.

Rhubarb and Roots 7-23 Geranium.

Rutabaga.

Salsify.

Spinach.

Swiss Chard.

Tobacco.

Tomato

Turnip

Vegetable Plants......

\section{FLOWER SEED}

Abronia.

Acacia.

Adonis .

Ageratum

Annual Poinsetta.

Alyssum.

Amaranthus

Antirrhinum

Angel's Trumpet.

Annual Garden Mix-

ture. .

Aquilegia

Arabis Alpina...... 4

Arctotis Grandis...... 45

Asparagus.......... 45

Aster............ . . .

Bachelor's Button.

Baby's Breath.

Balsams.

Begonia.

Bellis.

Bellflower

Blanket Flower

Blue-eyed Daisy

Brachycome.

Browallia

Burning Bush.

Bush Eschschoitzia.

Butterfly Flower.

Cacalia.

Calceolaria.

Calendula

California Poppy.

Calliopsis.

Callirhoe.

Campanula.

Candy tuft.

Canna.

Godetia.

Gourd, Ornamental,

see page.............
Grasses, Ornamental,

Gypsophila.

Helianthus.

Heliotrope.

Heuchera.

Hesperis.

44 Hollyhock

44 Hunnemania.

44 Ice Plant.

I

Lobel

Love-in-a-Mist

4 Lupinus.

52 Marshmallows.

17 Marigold.

46 Marvel-of-Peru.

46 Matricaria.

50 Mesembryanthemum

49 Mexican Fire Plant.

Mignonette . ....... 55

Mimosa.

Mimulus

Monkey Flower ...... 5

Mourning Bride..... 60

Musa.

Musk Plant.......... 54

Mysotis.......... 51

Nasturtium.....68-69

Nicotiana .......... 54

Nigella.

Painted Tongue....... 58

Pansy.............
Penstemon...... 56
Page

Periwinkle....... 61 Barley.......... Page

.. 55 Broom Corn......... 75

49 Phacelia............ 55 Canada Peas......... 75

48 Pheasant's Eye.....4 44 Cane........... 75

57 Pincushion Flower... 60 Corn, Field........ 78

49 Pink, May or Grass .. 50 Flax............. 75

49 Platycodon....... 55 Grasses..... 70-71-73-74

49 Poppy..........42-58 Kaffir Corn....... 75

49 Pottentilla........ 55 Oats.............. 79

49 Primrose.......... 57 Peanuts.......... 75

45 Pyrethrum

60 Ricinus.

49 Rocket.

77 Rock Cress

47 Rose Champion

49 Salpiglossis.

50 Salvia.

0 Sand Verbena.

46 Scabiosa.

Scarlet Sage.

Schizanthus.

5 Sensitive Plant..

Snapdragon

1 Snow-on-the-Moun-

tain...

50 Spider Plant.

51 Stockesia..

50 Stocks...

1 Swan River Daisy.

51 Sweet Alyssum...... 44

44 Sweet Peas.....65-66-67

44 Sweet Sultan....... 48

99 Sweet William

1 Sweet Violet...

4 Tassel Flower.

Ten Weeks Stock..... 59

Tobacco, Ornamental 54

51 Trumpet Flower.... 50

Vinca....

Violet.

Virginia Stock

Wahlenbergia

Wallflower.

Adlum

\section{CLI}

Allegheny Vine......

Ampelopsis...

Aristolochia Sipho

Balloon Vine......

Balsam Apple.

Black-Eyed Susan...

Boston or Japan Ivy 6

Butterfly Runner..

Brazilian Morning

Glory

Canary Bird Flower. 62

Cobaea Scandens.... 63

Cup and Saucer Vine. 63

Cypress Vine........ 62

3 Dutchman's Pipe.... 62

5

Hop, Japanese........6. 63

53 Hyacinth Bean....... 63

54 Ipomea ...........6.6. 64

54 Lathyrus Latifolius. 6

54 Maurandia........6. 63

Mina................6. 63

Morning Glory..... 54-64

Moon Flower........6.6 62

Mountain Fringe... 62

Mountain Rose....6.68 62

Passiflora.........6. 64

Passion Flower.........6.

Peas, Everlasting.... 64

Smilax...........6. 64

Tropaeoleum Cana-

riensis............6. 62

Wild Cucumber FARM AND FiÉD

Alfalfa......... 73

64

Potatoes.

Potatoes, Sweet..... 77

Rape............. 75

Red Top.......... 74

Rye $\ldots \ldots \ldots \ldots \ldots \ldots \ldots$
Speltz......

Sugar Cane........ 75

Sunflower.......... 75
Timothy........ 74

60 Vetch............. 75

wheat.............79

Plants a ind BülBs

Achillea ........... 33
Adam's Needle.... . 37

Ageratum......... 32

Althea.......... 30

Alternanthera..... 32
Alyssum........32-33

Amaryllis............ 38

Ampilopsis........ 31

Anemone......... 33

Aquilegia............. 33

Arundo Grass....... 35

Asparagus.............. 32

Baby's Breath....... 35

Bell Flower........ 34

Bignonia............. 31

Blanket Flower.......
Bleeding Hearts.....

Bleeding Hearts..... 33

1 Caladium........... 38

California Privet.... 30

61 Canna................. 38 


\section{ST. L. S. CO.'S CALENDAR FOR SEED PLANTERS In the Latitude of St. Louis}

JANUARY - Sow in Hot-Bed.-Early Beet, Early Cabbage, Forcing Carrot, Cauliflower, Farly Lettuce, Early Onions, Radish. FEBRUARY-Sow in Hot-Bed.-Early Beet, Brocenli, Early Cabbage. Forcing Carrot, Cauliflower, Celery, Cucumber, Egg Plant, Early Lettuce, Parsley, Pepper, Early Onions, Radish, Tomato.

MARCH-Sow in Hot-Bed.-Early Beet, Early Cabbage, Forcing Carrot, Cauliflower, Celery, Cucumber, Egg Plant, Koh! Rabi, Lettuce, Melon, Parsley, Pepper, Onions, Radish, Tomato, Herbs. Sow in Open Ground.-Beans, Beets, Cabbage, Cauliflower, Celery, Carrot, Cress, Leek, Lettuce, Onion, Parsnip. Peas, Potatoes, Radish, Spinach, Early Turnip, Onion Sets.

APRI-Sow in Hot-Bed.-Cucumber, Egg Plant, Melon, Pepper, Tomato. Sow in Open Ground.-Asparagus, Beans, Beets, Cabbage, Carrots, Cauliflower, Celery, Sweet Corn, Cucumber, Cress, Endive, Kale, Kohl Rabi, Leek, Lettuce, Melons, Onions, Parsley, Parsnip, Peas, Potatoes, Radish, Rhubarb, Salsify, Spinach, Tomato, Turnip, Sage, Herbs, Onion Sets.

MAT-Sow in Open Ground.-Artichoke, Asparagus, English Beans, Pole Beans, Bush Beans, Beets, Brussels Sprouts, Cabbage, Carrot, Cauliflower, Celery, Sweet Corn, Cress, Cucumber, Endive, Kale, Kohl Rabi, Leek, Lettuce, Melon, Okra, Onion, Parsley, Parsnip, Peas, Potatoes, Pumpkin, Radish, Rhubarb, Salsify, Spinach, Squash, Tomato, Turnip, Herbs.
JUNE-Sow in Open Ground.-Bush Beans, Lima Beans, Pole Beans, Beet, Carrot, Cabbage, Sweet Corn, Cress, Cucumber, Endive, Kale, Kohl Rabi, Lettuce, Melon Okra, Peas, Potatoes, Pumpkin, Radish, Salsify, Spinach, Squash, Turnip, Rutabaga. JULY-Sow in Open Ground.-Bush Beans, Beet, Carrot, Sweet Corn, Corn Salad, Cress, Cucumber, Endive, Gherkin, Kale, Kohl Rabi, Lettuce, Okra, Early Peas, Pumpkin, Radish, Spinach, Squash, Turnip, Rutabaga. Write for St. L. S. Co.'s Turnip Seed Price List.

A UGUST-Sow in Open Ground. Bush Beans, Corn Salad, Cucumber, Endive, Lettuce, Early Peas, Radish, Spinach, Squash, Turnip. Plant Winter Onions.

SEPTEMBER-Sow in Open Ground.-Cabbage or Cauliflower in Cold Frames, Corn Salad, Cress, Kale, Lettuce, Mustard, Winter Radish, Spinach, Turnip. Plant Winter Onions. Write for St. L. S. Co.'s Bulb Catalogue.

OCTOBER-Sow in Open Ground.-Corn Salad, Cress, Kale, Lettuce, Mustard, Spinach. Plant Hyacinth, Tulips, Narcissus and other Dutch Bulbs in open ground, pots or glasses.

NoVEMBER-Sow in Open Ground.-Plant Hyacinth Tulip, Narcissus and other Dutch Bulbs in open ground, pots or glasses.

\section{HORTICULTURAL BOOKS}

Agriculture, the Principles of-Prof. L. H. Bailey-\$ 125 Alfalfa-E. D. Coburn.................... 50

Animal Breeding-Thos. Shaw............... 15

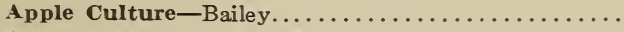

A sparagus Culture-F. M. Hexamer...............

Bee Keeping, the Mysteries of, Explained-L. C.

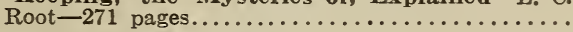

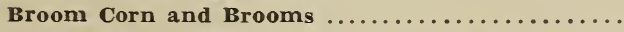

Cabbages, Cauliflower and Allied Vegetables-C. L.

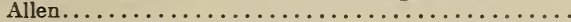

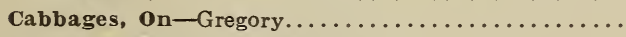

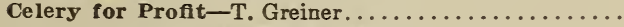

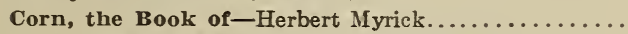

Corn Judging, Manual of-A. D. Shamel...........

Clovers and How to Grow Them-Thos. Shaw.....

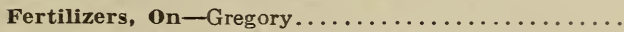

Forage Crops Other Than Grasses-Thos. Shaw....

Fruit Harvesting, Storing, Marketing-F. A. Waugh

Fumigation Methods-W. G. Johnson............

Gardening for Pleasure-Peter Henderson...........

Gardening for Profit-Peter Henderson............

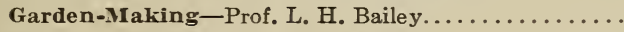

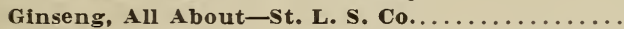

Hedges, Windbreaks, Shelters and Line Fences-E.

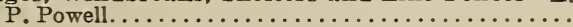

How to Make the Garden Pay-Gardiner..........

Horticulturists' Rule Book-Bailey..............

Insects and Insecticides-Clarence M. Weed, T. Tc. . Irrigation Farming-Lute Wilcox.............. Irrigation for the Farm, Garden and orchard-

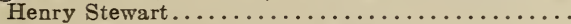

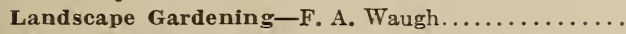
Manures; How to Make and How to Use Them-

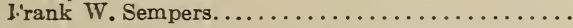

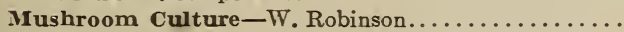
Mushrooms; How to Grow Them-Wm. Falconer.

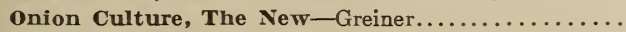

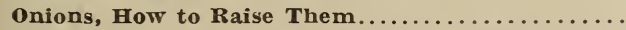
Our Farm of Four Acres and the Money We

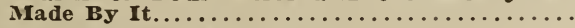

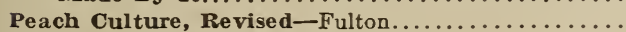

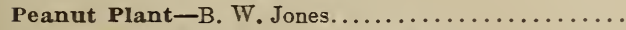

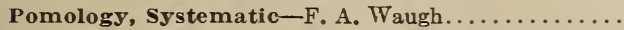

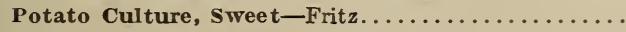

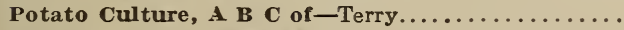

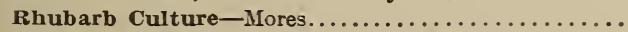
Soiling Crops and the Silo-Thomas Shaw......... Spraying Crops-C. M. Weed.

200
Strawberry, The A B C of the-Terry and Root Strawberry Culturist-Andrew S. Fuller.

Tobacco Culture.

Tomato Culture-Day, Cummins and Root

50 Truck Farming at the South-Dr. A. Oemler

Raffia and Reed Baskets.

100 Raffia and Reed Weaving-Knapp.

So 45

\section{POULTRY}

American Standard of Perfection

150

Egg Farm, The New-H. H. Stoddard

100

500 Questions and Answers.

999 Questions and Answers

50

Philo System.

100

Poultry Lessons for the Amateur

Poultry Appliances and Handicraft-G. B. Fisk

25

50

Poultry Architecture-G. B. Fisk.

Poultry Raising; 500 Questions and Answers

Profits in Poultry

100

Profitable Poultry Keeping in All Branches

Profitable Poultry Houses and Appliances.

Successful Pigeon Raising.

20th Century Poultry Buildings.

Why Poultry Pays and How to Make it Pay

\section{PETS}

The Amateur Aquarist-Mark Samuel

Aquaria; All About the Care of Fancy GroldfishPage.

Bird Fancier, American-D. J. Bowne and Dr. Fuller Walker. Valuable for all bird lovers.

Canary Birds-Their Breeding, Habitation, Diseases, etc....................................... English Edi-

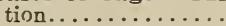

Diseases of Dogs-A valuable book for the lover of the

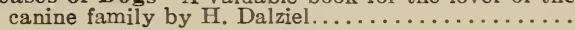

\section{FLOWERS}

Bulb Culture - Henderson.................. 25

Dahlia, The-L. R. Peacock................. 30

Flowers; How to Grow Them-Rexford.......... 50

Flower Garden, The Beautiful-Matthews........ 40

Floriculture, Practical-Henderson........... 150

Home Floriculture-Eben E. Rexford.......... 100

House Plants, Success With-L. P. Hillhouse.......

Window Flower Garden-Heinrich .............
Sweet Peas, All A bout-Hutchins ............. 20 


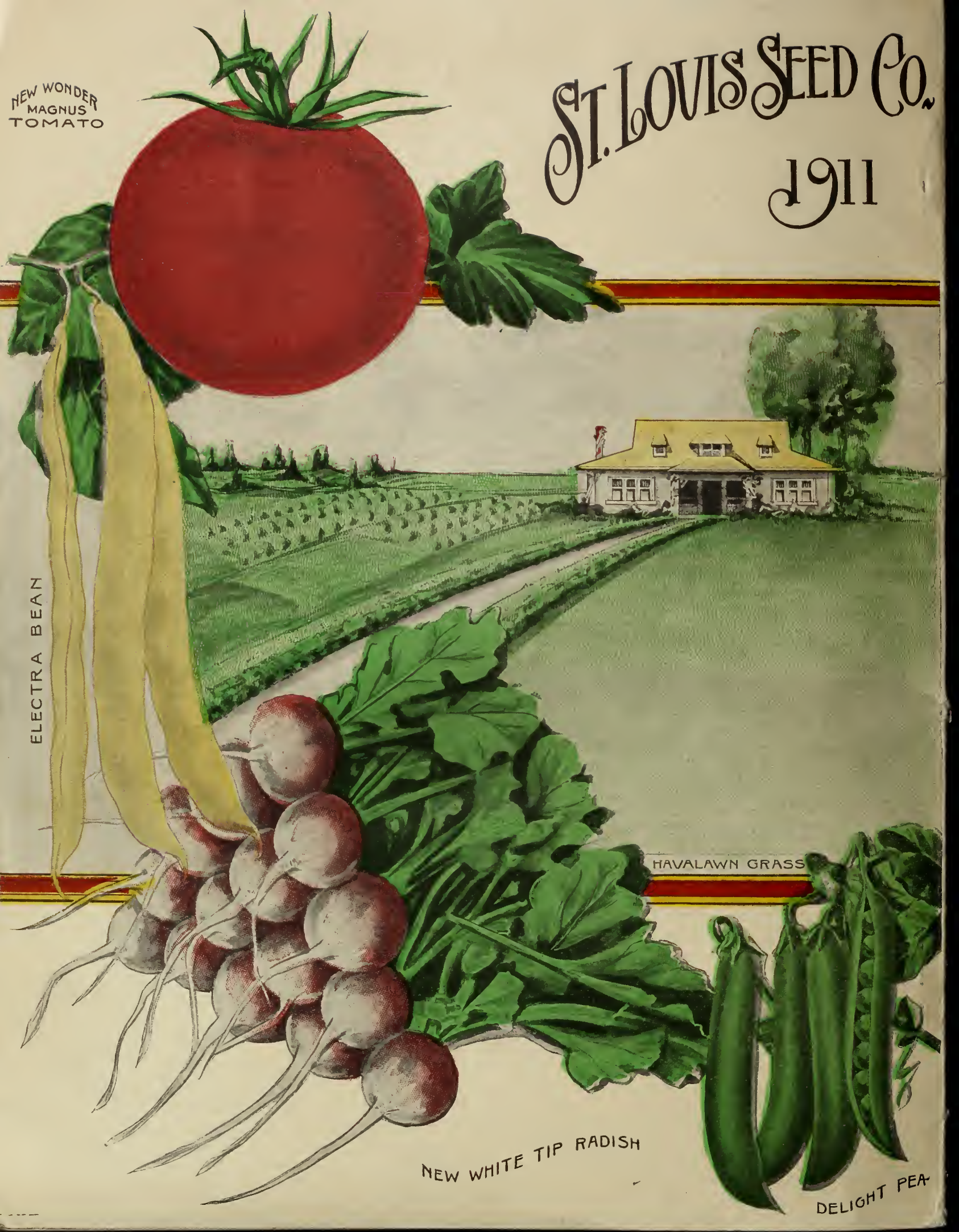

